\title{
FRACART FROMA
}

Memory and Truth-Telling in

Post-Shining Path Peru

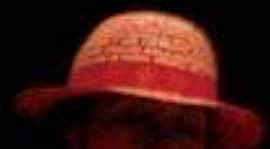


ART FROM A FRACTURED PAST 



\section{ART FROM A FRACTUPED PAST}

MEMORY AND TRUTH-TELLING IN

POST-SHINING PATH PERU

CYNTHIA E. MILTON / EDITOR

AFTERWORD / STEVE J. STERN

Duke University Press / Durham and London / 2014 
(C) 2014 Duke University Press

All rights reserved

Printed in the United States of America on acid-free paper $\infty$

Typeset in Whitman by Copperline Book Services, Inc.

Library of Congress Cataloging-in-Publication Data

Art from a fractured past : memory and truth-telling in

post-Shining Path Peru / Cynthia E. Milton, editor.

pages $\mathrm{cm}$

Includes bibliographical references and index.

ISBN 978-o-8223-5515-1 (cloth : alk. paper)

ISBN 978-o-8223-5530-4 (pbk. : alk. paper)

1. Arts-Political aspects-Peru. 2. Collective memory in art.

3. Peru-Politics and government-1980- I. Milton, Cynthia E.

NX180.P64A89 2013

$700.985^{\prime} 09048-\operatorname{dc} 23$

2013025658

Duke University Press gratefully acknowledges the support of the

Canada Research Chair in Latin American History at the Université de Montréal, which provided funds toward the publication of this book. 
Para Carlos Iván Degregori, nuestro querido maestro sabio, siempre presente 

CONTENTS

Acknowledgments ix

INTRODUCTION / CYNTHIA E. MILTON

Art from Peru's Fractured Past 1

PART ONE

VISUAL REPRESENTATIONS OF RECENT PASTS

ONE / CYNTHIA E. MILTON

Images of Truth: Rescuing Memories of Peru's

Internal War through Testimonial Art 37

TWO / EDILBERTO JIMÉNEZ QUISPE

Chungui: Ethnographic Drawings of Violence

and Traces of Memory 75

THREE / MARÍA EUGENIA ULFE

Narrating Stories, Representing Memories:

Retablos and Violence in Peru 103

PART TWO

TELLING STORIES OF POLITICAL VIOLENCE

FOUR/VÍCTOR VICH

Violence, Guilt, and Repetition:

Alonso Cueto's Novel La Hora Azul 127 
viii / CONTENTS

FIVE / LUIS ROSSELL, ALFREDO VILLAR, AND JESÚS COSSIO

Rupay: (Hi)stories of Political Violence in Peru, 1980-1984 139

SIX / PONCIANO DEL PINO

Ayacuchano Cinema and the Filming of Violence:

Interview with Palito Ortega Matute 153

PART THREE

PERFORMING A FRACTURED PAST

SEVEN / RICARDO CARO CÁRDENAS

Commemorative Paths in Sacsamarca 179

EIGHT / CYNTHIA M. GARZA

Colliding with Memory: Grupo Cultural Yuyachkani’s

Sin Título, Técnica Mixta 197

NINE/ JONATHAN RITTER

The "Voice of the Victims":

Testimonial Songs in Rural Ayacucho 217

AFTERWORD / STEVE J. STERN

The Artist's Truth: The Post-Auschwitz Predicament

after Latin America’s Age of Dirty Wars 255

Bibliography 277

Contributors 293

Index 297 
This project started ten years ago, almost to the day, when I wandered through Ayacucho's central plaza on the late afternoon prior to the Peruvian Truth Commission's arrival the next day to submit their Final Report. Colorful carpets (alfombras) made by schoolchildren and local groups from flower petals, chalk, and other materials surrounded the plaza, posterboards displayed images of the conflict and visitors' comments about them, in the corner stood an enormous stage in a style of a wooden triptych retablo. Nearby, an exhibition displayed some of the entries for an art contest on memories of the internal conflict. On this day, and those that followed, I was struck by how visually rich the conflict was and its aftermath as Peruvians engaged with their recent fractured past. As an historian, I wondered what stories and memories emerged from these representations. A few of us were pondering similar questions at the time, Olga González, Jonathan Ritter, María Eugenia (Makena) Ulfe, and Víctor Vich, among others. Soon it became clear that the range and array needed a cooperative and collective approach to begin to understand the myriad of cultural responses to the conflict. This edited volume is the result. However, the work is far from complete. A whole new generation of Peruvians and Peruvianists are continuing to ask about the cultural impact and means of broaching Peru's conflict.

The intellectual origins of this book also trace back to a workshop held on Robben Island, organized by the University of Wisconsin-Madison's Legacies of Authoritarianism (LOA) Research Circle. With its infamous history as a former leper colony, holding spot for immigrants, and later apartheid prison, the island has since transformed into a memory museum and education center. Here in June 2000, activists, artists, practitioners, former and future truth commissioners, academics, journalists, and students from around the world came together to reflect on the dark heritage of authoritarian rule. Over the course of those few 
days, both art as a medium for truth-telling and the creative practices necessary for transition away from authoritarian regimes came to the fore. One result of our conversations was a book that tried to visually lay out the possibilities of artistic engagement with difficult pasts, The Art of Truth-Telling about Authoritarian Rule. I thank Leigh A. Payne, Ksenija Bilbija, and Jo Ellen Fair for this experience, and Louis Bickford as well for bringing me into the larger project.

Another root of this book lay deeply in the Social Sciences Research Council (SSRC) training and research project led by the faculty scholars Elizabeth Jelin, Carlos Iván Degregori, Eric Hershberg, Steve J. Stern, among others. While I was only indirectly involved in this SSRC project (via the LOA Research Circle) and only one contributor to this book, Ponciano del Pino, had an official role in it, it created a whole generation of Latin and North American scholars dedicated to studying the aftermath of dictatorships in Peru and the Southern Cone. This SSRC project inflects this book, and many of us have benefited from the energy and dynamism that continues to be felt in the region.

Many, many people have contributed to this book in conversation and public presentations (in particular at a panel on this topic held at Latin American Studies Association meeting in Montreal in 2007 and at the 2008 conference in Lima coorganized by the IEP and IDEHPUCP five years after the Peruvian Truth and Reconciliation Commission). Just to name only some people who have participated in discussions leading to this book: Carlos Aguirre, Claudio Barrientos, Karen Bernedo, Ralph Buchenhorst, Jo-Marie Burt, Gisela Cánepa, Peter Dietsch, Eduardo González, Olga González, Elizabeth Jelin, Richard Kernaghan, Catherine LeGrand, Erica Lehrer, Salomón Lerner, Lika Mutal, Nelly Plaza, Félix Reátegui, José Luis Rénique, Javier Torres, Alberto Vergara, María Inez Vásquez, and Markus Weissert. Others are acknowledged in the following chapters. I express my gratitude to all the artists whose works are included here, and to the different organizations that have granted permission for their inclusion, especially the Servicios Educativos Rurales. I heartily acknowledge as well those people who have helped with the tricky mechanics of putting this mélange of languages, texts, and images together: Jen Akers, Elizabeth Becker, Jane Remick, and Katherine Saunders-Hastings for their assistance in various stages of translation; Andrea García, Socorro Naveda, Vera Lucía Ríos, and Sofia Vera for information that they helped gather; Bill Nelson for the maps; and 
Lori Curley for the index. Thanks to Geneviève Dorais, Marc Drouin, MarieChristine Dugal, Steve Lamarche, Tuong-Vi Nguyen, Louis Otis, Nicolás Rodríguez, Hélène Rompré, and Guillaume Tremblay for their comments inside and outside the classroom. Monica Eileen Patterson (another LOA connection) and Camille Boutron have also commented on earlier drafts, for which I am grateful. I thank Raúl Hernández Asencio and Pati Zárate for their friendship and for overseeing this project since its early stage as a loose idea. Stephan Rinke at the Latin American Institute at the Freie Universität and Barbara Göbel at the Ibero-Amerikanisches Institute in Berlin provided me with an ideal setting in which to complete this manuscript. I am fortunate to have had such dedicated external readers for this project, one anonymous, the other Paulo Drinot. They both provided very insightful comments and more examples to consider. Paulo continued to participate in this project until the final version and thus deserves special recognition for his hand in this book. Many thanks to Valerie Millholland, who heard of this project many years back and showed enthusiasm for it, and to Gisela Fosado, Jessica Ryan, and Martha Ramsey for their help to bring it to fruition.

My gratitude to the many funding organizations that have contributed to this book and to the larger research projects on alternative truth-telling and art in the aftermath of violence of which this book is a part: the Social Science and Humanities Research Council of Canada, the Fonds québécois de recherche sur la société et la culture, the Canada Research Chairs Program, the Faculté des arts et des sciences at the Université de Montréal, and the Alexander Von Humboldt Foundation.

This book is dedicated to Carlos Iván Degregori, who has been a mentor without borders for many of us and an inspiration to all. He understood the importance of the intersection between academia and public obligation. Through his compassion and intellect, Carlos Iván shows us how with one life it is possible to touch many, to listen, to learn, and to share with others. 


n Adiós Ayacucho [Farewell Ayacucho] Julio Ortega recounts from the perspective of Alfonso Cánepa, a community leader from the department of Ayacucho, the travails of finding postmortem justice in a country that offers little justice for the living. When he was accused of being a terrorist - rather than a peasant leader - the military mutilated his body and threw what was left of it into a pit, leaving out many of his bones and thus denying him the possibility of a proper burial and eternal peace. Since his death Cánepa has worked to reconstruct his body, trying to get a sympathetic hearing from the president of the Republic in the hope that the head of state will return his bones to him. Rejected, he climbs into the tomb of the conquistador Francisco Pizarro and takes some of Pizarro's bones to complete his own skeleton. Written in 1986, this novella evokes the tragedy and brutality of the war in highlands Peru, the racism and indifference that lay at the heart of the conflict, and the long-standing historical violence dating back to the arrival of the Spanish. ${ }^{1}$

Alfonso Cánepa's story, though fictional, recalls the experience of hundreds of thousands of Peruvians whose lives from 1980 until the mid-199os were convulsed by an internal war. ${ }^{2}$ According to the Peruvian Truth and Reconciliation Commission, which studied the years from the launch of Shining Path's "People's War" to the fall of the Fujimori government in 2000, over 69,000 people were killed or disappeared, some 4,6oo clandestine burial sites pockmark the country, over 40,00o children were left orphans, over 20,000 women were left widowed, and some 600,0oo internal refugees migrated to the cities in search of safer lives. ${ }^{3}$ The scale of the destruction, loss of family and loved ones, personal suffering, and fracturing of life trajectories and social bonds 
impedes comprehension. Yet the internal war of Peru necessitates reflection and historicization. ${ }^{4}$

Art-such as Ortega's short story-offers a powerful means for recounting the past and for reaching a kind of understanding. The ability of art to speak about atrocity has been debated since Theodor Adorno famously remarked that to write poetry after Auschwitz was "barbaric." His aphorism has often been interpreted to mean that it is impossible, both actually and morally, to represent the Holocaust, and perhaps more broadly any atrocity, via art. ${ }^{5}$ Yet Adorno later in life acknowledged poetry as an important means of communication for "perennial suffering has as much right to expression as a tortured man has to scream." Over the half century since the Holocaust, a plethora of artworks has emerged to broach the difficult - in the meanings of both sensibility toward and comprehension of-thus allowing us decades later to move beyond the taboo of representing and giving expression to shameful and horrific pasts. ${ }^{7}$ Art may express what formal language cannot. ${ }^{8}$ We should recognize the significant role art can play in making difficult pasts comprehensible, even if only in part. Thus, in a reworking of Adorno's famous words, Steve J. Stern suggests that to not produce art in the aftermath of suffering would be to allow barbarity to reign unchecked. ${ }^{9}$

Indeed, in Latin America, one of the intended aims of art in response to atrocity seems to be this: to contest the barbarity committed and to restore the humanity of citizens who have been harmed. In the transition from state violence to democracy and the post-transitional period, issues of representation and memory have come to the forefront of political and cultural analyses and debates about conflict and repression in Latin America. Protest art against authoritarian regimes and violence has made way for memorial art. In Argentina, for instance, siluetazos (silhouettes), which stood out as silent protests and evocations of missing citizens, now adorn memory sites dedicated to the desaparecidos (disappeared). Yet art may maintain continuity in its role regardless of regime type: whether under dictatorial or democratic rule, art contests any totalizing vision of state power. During dictatorships, to make art could be an act of resistance, as when Chilean women stitched picture arpilleras (appliqués) whose imagery denounced the Pinochet regime's human rights abuses. ${ }^{10}$ So, too, in post-conflict democracies, art reminds audiences of the ongoing tensions of 
the unresolved past in the present. For instance, post-civil war novels in Central America reference the violence of earlier decades in the context of today's insecurity; ${ }^{11}$ and the creativity of the escraches (public denunciations of perpetrators) by Argentine and Chilean youth "remind us that while the dictatorships and even democratic regimes have tightly controlled our understanding of the real, cultural practices constantly subvert that discursive order."12

Art may help to achieve a fuller expression and better understanding of difficult and contested pasts. In a conversation between the historian Gonzalo Sánchez and the artist María Elvira Escallón, who made a photography exhibition after a bombing of a social club in Bogota, Sánchez reflects on the limits of written texts in recounting the Colombian violence: "a text cannot say everything about the pain that covers our daily tragedies. We need to turn to images, and the multiple possibilities of artistic language."13 Art may help not only those who have gone through traumatic events to put shape and give meaning to their experiences - to express something about the pain, to paraphrase Sánchezbut art may also help those who have not directly experienced such events to come closer to a sympathetic awareness of them. As Kyo Maclear has written in the context of post-atomic bombings Japan, art can move viewers "emotionally and intellectually toward the unknown." ${ }^{14}$ For some survivors, art came out of necessity and a desire to record what happened for future generations: "even now [thirty years later] I cannot erase the scene from my memory. Before my death I wanted to draw it and leave it for others," said Iwakichi Kobayashi, a seventyyear-old survivor of the atomic bombing of Hiroshima. ${ }^{15}$ Thus, art also asks contemporary and future others to bear witness to the artists' acts of witnessing.

It is this combination of telling, witnessing, and drawing others toward the unknown by representing it through artistic means that is explored here. This book considers the role of literary, visual, oral, and performance arts in the sharing of individual and collective memories as a means to complement our historical understanding of Peru's fractured past. This combination of artistic forms of expression is of fundamental importance, for it allows a much broader swath of society to participate in the reconstruction and re-presentation of the past - often marginalized groups who would otherwise be excluded from mainstream media and modes of communication. ${ }^{16}$ In societies where the written word may impede the narration of their experiences, and in the wake of severe 
violence when the ability to speak may be blocked, ${ }^{17}$ art may be one of the few modes by which people can recount the past. Thus, the compilation of artworks in this book represents a call for an expansion of the archive to include other repositories of memory and history, beyond state-produced, written records and the collection of oral testimonies that emerge through official inquiries like truth commissions and trials. ${ }^{18}$

\section{From the Internal Conflict to Memory Battles}

Much of the art studied in this book is in dialogue with or takes as its point of departure the work of the Peruvian Truth and Reconciliation Commission (Comisión de la Verdad y Reconciliación; CVR), a formal body assigned to investigate Peru's internal conflict of 1980-200o. While artists had been producing art during this period, the emergence of a truth commission in 2001 broadened the public sphere for discussing this past by other means.

After the sudden fall of Alberto Fujimori in November 2000, the option of a truth commission - an established mechanism used by other countries in the post-Cold War era-stood out as one of the ways that Peru's government could mark regime change. ${ }^{19}$ Unlike Latin American truth commissions that had investigated periods during military and authoritarian regimes, Peru's commission addressed violence that had occurred mainly under the stewardship of democratically elected governments: those of Fernando Belaúnde Terry (19801985), Alan García Pérez (1985-1990), and Alberto Fujimori (1990-2000, with the suspension of Congress in 1992). In addition, whereas other truth-seeking mechanisms in the Southern Cone had named state forces as primary perpetrators, Peru's truth commission found the armed group the Communist Party of Peru-Shining Path (Partido Comunista del Perú-Sendero Luminoso) largely responsible. Furthermore, the Peruvian truth commission held a wider mandate than those of its neighbors. For instance, the CVR's scope was considerably broader than that of the first Chilean truth commission, known as the Rettig Commission, which at the time could investigate only the cases that led to death and disappearance. ${ }^{20}$ In Peru, the CVR investigated assassinations and kidnappings, disappearances, torture and other serious wounds, harm against collective rights of Andean and native communities, and other grave violations of people's rights. ${ }^{21}$ The cvR's mandate was to determine the responsibility for 
abuses and violations, identify and report on the experiences of victims, and develop proposals for reparations and reforms. The CVR sent out investigative teams to collect testimonies from remote regions. Furthermore, the CVR held public hearings (audiencias públicas) wherein local community members could participate, unique among Latin American truth commissions and perhaps a modified form of South Africa's sessions for victims and their families. ${ }^{22}$ As part of their attempt to make the past accessible, the cvR's documentation is openly available in an archive constructed especially to house it. ${ }^{23}$ Internationally, the Peruvian truth commission is considered successful because of the depth and breadth of their investigation, which was based on almost seventeen thousand testimonies in Peru's twenty-four departments, collected, compiled, and analyzed by a staff of over five hundred members. ${ }^{24}$ In addition, the CvR forwarded forty-seven cases to the Office of the Prosecutor General to pursue.

In the case of Peru justice and truth were both goals of the CVR, thereby breaking with the expected framework of previous transitional justice scholarship of the 1980s and 199os that assumed states could pursue only one at the expense of the other. After the strong civil society protests against Fujimori's third five-year mandate, which contributed to his sudden resignation, the subsequent interim president, Valentín Paniagua, took on parallel projects of accountability and truth-seeking. Paniagua's transitional government returned Peru to the jurisdiction of the Inter-American Court of Human Rights while also establishing an ad hoc state and civil society committee to consider forming a truth commission. Human rights groups, who for years had been coalescing under the umbrella of the National Human Rights Coordinator (Coordinadora Nacional de Derechos Humanos), played a key role in both the broad societal efforts to topple Fujimori and in establishing an agenda for public truth-seeking. ${ }^{25}$ A series of pivotal events further combined to create a propitious environment for a truth commission. First, the Inter-American Court of Human Rights ruled that the Peruvian state was responsible for the deaths of residents of Barrio Altos in 1991 and repealed the 1995 amnesty laws protecting security forces from prosecution for any abuses committed since 1980. Second, videos were leaked that incriminated opposition parties, the armed forces, and businessmen in the Fujimori government's web of corruption. These events, in particular the damning videos, weakened the political and military elites and bolstered their resolve 
to publically distance themselves from the Fujimori regime and to support the new democracy. ${ }^{26}$ As Carlos Iván Degregori noted, in Peru the truth commission, unlike those of other countries in the region, emerged not from a "pacted transition" but from the auspicious political vacuum left by the "collapse of the authoritarian regime." 27

Despite this favorable setting for a broad-reaching truth commission, and despite having the benefit of other countries' experiences with truth commissions, the CVR nevertheless faced constraints: it had a confined period of twenty-four months to conduct investigations into the previous twenty years, limited resources, and difficulties with translating from Quechua and other indigenous languages into Spanish. ${ }^{28}$ Furthermore, the public, though openly embracing the return to democracy, had a mixed reaction to a call for a truth commission. Some survivors and groups distrusted this newer manifestation of the state that had previously harmed them; some evangelicals chose to move on, not look back; and people questioned such expenditures of money; among other concerns. ${ }^{29}$ With the change of president from Paniagua to Alberto Toledo, "reconciliation" was added to the commission's tasks, which had originally focused on truth-telling alone, thus perhaps laying the groundwork for frustrated expectations and fears of impunity and amnesty. ${ }^{30}$ The CVR itself was a compromise, bringing together different sectors of society, including members from Peru's diverse political spectrum. The appointed commissioners came from various political parties and societal groups, including a retired air force general, a former Fujimorista congresswoman, academics, members of church and human rights groups. ${ }^{31}$ This compromise, however, was not as marked as those of other countries in transition had been: since Shining Path and the Revolutionary Movement of Túpac Amaru (Movimiento Revolucionario Túpac Amaru; MRTA) no longer posed a threat, the interim government did not need to negotiate with an armed movement, nor did the government need to make large concessions, such as a blanket amnesty, to the political and military elites, since they had been weakened by scandal.

The CVR's Informe final (Final Report), made public August 28, 2003, attempts to give both an account of the violence, of what happened, and an explanation of the violence, of why it happened. ${ }^{32}$ Looking at this period of conflict from 1980 to 2000 (including the years from the capture of Shining Path's leader, Abimael 
Guzmán, in 1992 to the end of Fujimori’s authoritarian regime in 2000), the CVR's Final Report presents searing data of the nation's suffering, whose extent had been much greater than had been imagined at the time. ${ }^{33}$ The many conclusions of the CVR added up to a historical narrative that evinced the long-standing problems of racism against the nation's indigenous population, centralization of power in the hands of the predominantly coastal mestizo-white elite, and implementation of "rule by abandon" whereby the state was largely absent in large swaths of national territory. ${ }^{34}$ Three out of every four victims were speakers of Quechua or other indigenous languages, many of whom had not finished primary school and were poorly literate, lived in rural regions, and were engaged in agricultural production. ${ }^{35}$ The regions hardest hit were small, isolated villages in the Peruvian highlands (in the departments of Ayacucho, Huánuco, Huancavelica, Apurímac, Junín, and San Martín), representing 85 percent of the victims. Many were literally pueblos perdidos, small forgotten villages and hamlets with only difficult access to urban centers. The violence affected victims differently as to not only region and ethnicity but also age and gender: over 55 percent of the victims were men (most between the ages of twenty and forty-nine) targeted by Shining Path and state armed forces alike; most of the women who died (nearly 20 percent of all ages) were the victims of indiscriminate violence and massacres leveled against communities. ${ }^{36}$ Almost all cases of sexual violence reported to the CVR were committed against women, mainly rural. ${ }^{37}$ It was these profound class, ethnic, and gender cleavages which ultimately explained why, according to the president of the CVR, Dr. Salomón Lerner, "tens of thousands of citizens can disappear without anyone in integrated society, in the society of the nonexcluded, noticing a thing." ${ }^{38}$

In their findings, the CVR spread the blame widely for the violence and its escalation. While the commission condemned the armed group Shining Path as the main perpetrators of violence (in 54 percent of cases of death and disappearance) and to a much lesser extent the urban-based MRTA (1.5 percent), the commission also placed responsibility in the hands of successive governments (Belaúnde, García, and Fujimori) and the political parties who had abdicated authority to the armed forces (found responsible for 29 percent of the deaths and disappearances), and police (7 percent). ${ }^{39}$

Thanks to the work of the CVR, we now have more testimonies, statistics, and case studies that contribute to our awareness of the conflict's hard facts 


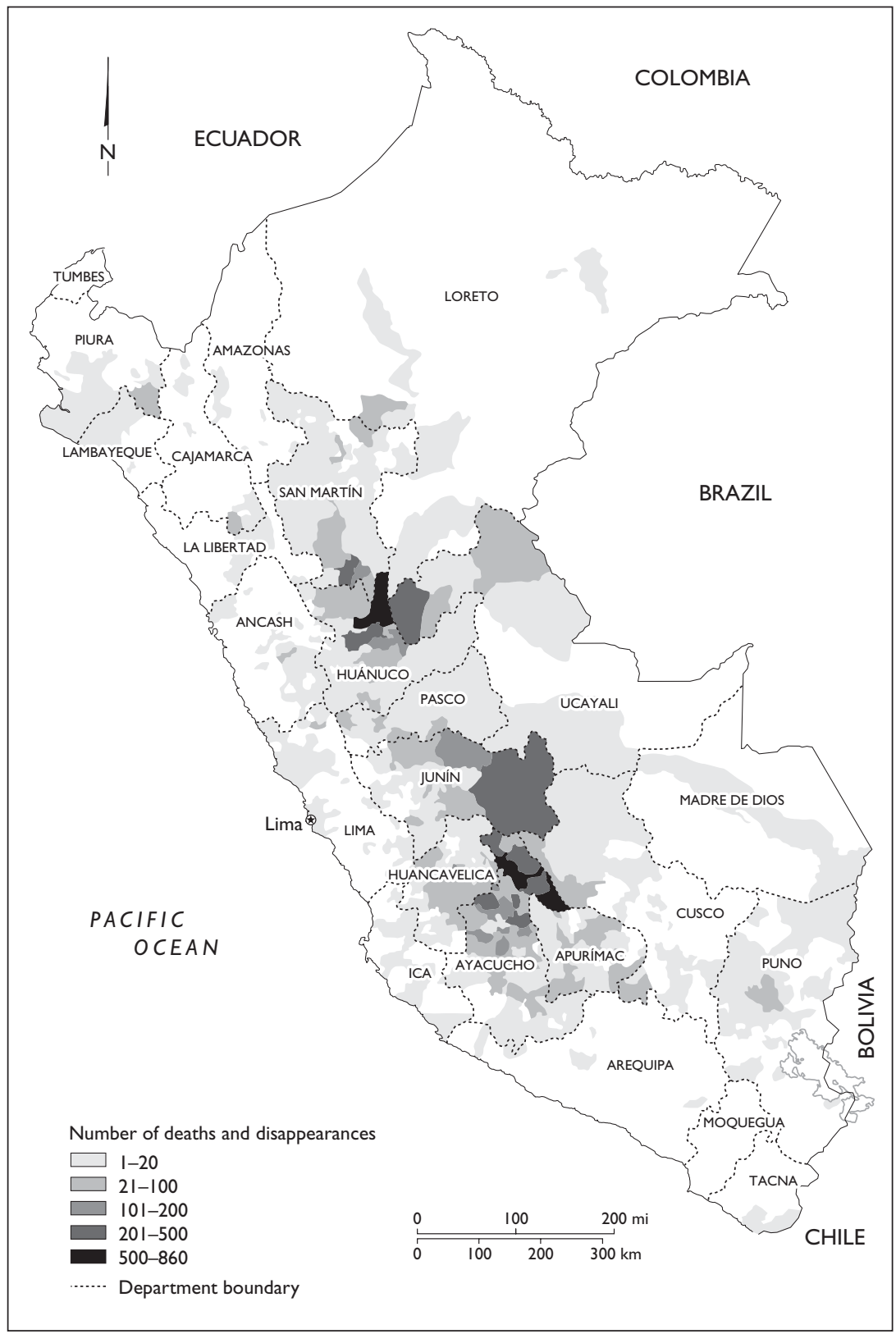

MAP 1. Deaths and disappearances (1980-20oo) according to Comisión de la Verdad y Reconciliación, Informe final (Lima: Comisión de la Verdad y Reconciliación, 2003), vol. 1, 157. Reproduction by Bill Nelson. 
and historical truths. ${ }^{40}$ The Peruvian truth commission was the main national effort to reconstruct what had happened and create a new (potentially national) narrative about the internal conflict. Yet, probably as in all post-conflict regions, the history remains contested, far from any kind of consensus or single version. The difficulty comes perhaps in trying to give an explanation of why events happened and to string together the years of violence into a coherent historical narrative, one with a beginning, middle, and end. According to Lerner, the human rights violations suffered during this period "exceed the amount of human loss suffered by Peru in all the external and civil wars that have happened in its 182 years of independence," thus making comprehension difficult. ${ }^{41}$

Yet, despite the lack of a single, coherent narrative, most Peruvians would probably agree on a vague outline of the internal conflict: that the nation underwent a wave of violence that affected predominantly highland and Amazonian communities, and that by the early 1990s this violence could be felt in Lima (especially after the July 1992 car bombing on Tarata Street in Miraflores, an affluent neighborhood in Lima). Nevertheless, much heated debate is fueled by competing versions of details of the conflict (and even of what to call itconflict/war/political violence) and, particularly, of who was responsible for the violence and to what extent. These memory battles continue to rage today.

It would be too simple to say that there is an official versus a nonofficial version of the conflict, since a plethora of camps exists, each with their own experiences and memories. That said, the two most prominently circulating narratives of this period can be characterized as "salvation memory" and "human rights memory." 42 In "salvation memory," espoused mainly by the armed forces and neoliberal elites, human rights violations were committed by a few rogue elements in the armed forces, Fujimori's heavy hand and disregard for human rights was the price paid for breaking Shining Path, Shining Path as instigator was thus solely responsible for the violence, and "we" in Lima did not really know the extent of what was going on (and with this lack of knowledge comes a kind of absolution). This narrative presents Fujimori as the economic and physical savior of Peru: he saved Peruvians from García's hyperinflation, captured Abimael Guzmán, thus effectively decapitating Shining Path, and he later crushed the last of the much smaller guerilla group MRTA, in a dramatic resolution to a nearly four-month hostage crisis. ${ }^{43}$ 
The "human rights memory" narrative, held by many human rights groups and organizations of affected family members, does not portray the end of the internal conflict as a victory over terrorism but situates the violence as an extension of ongoing legacies of social and political inequalities of which Shining Path was a symptom and on which Shining Path was able build its movement. Shining Path, the main perpetrator of violence, launched a conflict that was exacerbated by the armed forces' "dirty war" tactics, which did not respect the rule of law. ${ }^{44}$ In this narrative, the role of civil society, the self-defense patrols (rondas), and individual acts of heroism are highlighted. The "human rights memory" narrative further points to what the "salvation memory" effaces: Fujimori's failure to root out the causes of Shining Path's strength (endemic poverty, racism, unequal access to economic and social resources and the benefits of inclusion within the nation-state). This narrative clearly allocates blame for the escalation of violence to two competing forces-Shining Path and the state-yet tends to focus more on the violence committed by the state and perpetuates the image of Peruvians as caught between these "two fires." This focus on responsibility is slightly different from that of the CVR's Final Report, which emphasizes Shining Path's violence and acknowledges the armed forces' human rights abuses but also points a finger at the nonviolent actors in Peruvian society in general for having produced a "grammar of violence" 45 that fostered the injustices that lay at the heart of the violence.

The Final Report of the CVR is the closest thing Peru has to an official version of the conflict. Yet, even though the CVR was government mandated, no administration has claimed it as their own, thus, eschewing any self-reflection by the state that would bring about the changes recommended within the Final Report. The work of the CVR - whose impact continues as a reparations program slowly advances, cases come before the judiciary, and a proposed national memory museum (Lugar de la Memoria, la Tolerancia y la Inclusión Social [Place of Memory, Tolerance and Social Inclusion]) takes shape-has occurred in the context of antagonistic relationships with subsequent administrations. Thus it is not quite accurate to refer to the CVR's Final Report as "la historia official"; it is an "official" history with which most officials are ill at ease.

Domestically, the commission faced serious challenges in the diffusion of their findings, particularly from the political party Alianza Popular Revolucionaria 
Americana (APRA), Fujimoristas (supporters of Fujimori), some high-level church officials, and the armed forces, all of whom were named as responsible for facilitating the violence. A campaign to discredit the commission's findings led to accusations of conflicts of interest among commissioners, claims of malfeasance, and the use of the appellation "lie commission." 46 The Office of the Prosecutor General seemed reluctant to pursue the criminal cases forwarded to them by the commission, making public statements that potentially undermined the public reception of the commission's work overall. ${ }^{47}$ Importantly, the statistical findings, while most likely giving general indicators of tendencies, remain in question. ${ }^{48}$ The Final Report held the limelight for a relatively short time after its publication. Indeed, it may have spurred more debate prior to its actual publication than immediately after. ${ }^{49}$ After the report's release, the media quickly turned to issues of the nation's economy.

Former members and advocates of the commission have found it difficult to engage the public in a sustained way or get the Final Report adopted as the national account of the conflict years, despite their efforts to disseminate the CVR's findings through public hearings, photography exhibitions, workshops, and the publications of a book-length version of the Final Report, Hatun Willakuy, ${ }^{50}$ and a forty-page bilingual summary, among other initiatives. Nevertheless, the commission's work and memories of this recent past have continued to take center stage, abruptly at times, in the national media - as happened during Fujimori's trials, on the occasion of the vandalizing of the memorial to the nation's victims El Ojo que Llora (The Eye That Cries) in Lima, and when the political wing of Shining Path (Movimiento por Amnistía y Derechos Fundamentales) attempt to register as an official political party.

Memory of the war years in Peru does not seem at risk of becoming "inert historical memory" ${ }^{\prime 1}$ in national public discourse or of just emerging episodically in the form of "memory irruptions." ${ }^{2}$ Since the publication of the Final Report in 2003, memory work for a human rights narrative has been advancing in fits and starts, and major breakthroughs have occurred in promoting public discussion of the past: the sentencing of Alberto Fujimori to twenty-five years in prison for crimes against humanity, the Berlin Golden Bear award for the film The Milk of Sorrow (La teta asustada, renamed Fausta) about the intergenerational effects of violence, and President García’s reluctant acceptance of the German 
government's donation of funds to build a memory museum in Lima. Steadily, a new generation of Peruvians are active in the creation of intellectual forums for the discussion of the past, for example international conferences, working research groups, and Internet blogs.

And there is a boom in cultural production by individuals and groups affected by the violence, concerned citizens, and NGos; this book only touches on some of them. This cultural output expands beyond statues of fallen soldiers and the traditional memorial art of plaques and monuments to victims, and includes a range of creative engagements with the past. The Scarf of Hope (Chalina de Esperanza), more than a kilometer long, incorporates knitted names and images, scraps of clothing, and at times the favorite colors of women's disappeared loved ones. ${ }^{53}$ Young artists and activists, mainly from Lima, travel the country setting up their portable exhibits as part of the Itinerant Museum: Art for Memory (El Museo Itinerante Arte por la Memoria). ${ }^{54}$ El Ojo que Llora in Lima has been successfully used as a space to commemorate and serve as a meeting point for families of victims and human rights groups. "Little eyes" (ojitos) and memorial art more broadly have sprouted up in the highlands in remembrance of communities' dead and disappeared. ${ }^{55}$ And Peru has joined the international boom to construct memory museums, even if the one in Lima advances slowly. Affected groups and communities have built regional museums, many with the help of human rights organizations and international financial assistance, in Ayacucho (Huamanga), Huancavelica, Huanta, Putacca, Totos, Lucanamarca, Huamanquiquia, Pampachacra, and elsewhere. These casas de memoria (memory houses) curate Peru's difficult history through the display of ceramics, textiles, paintings, wax figures, retablos (three-dimensional boxes), clothing, testimonial excerpts, letters, photographs and more in their exhibition spaces, adorning their buildings with murals, and placing sculptures in gardens of reflection. ${ }^{56}$

Yet the question remains to whom all this memory work is speaking, and how effectively this message is getting across to those who wish not to know or to see things otherwise. Successful attempts to bring a human rights account of the past into the present are dampened by counter-narratives and opposing memories. One example of continued maneuvers to erase or rewrite the past was the failed 2010 bid to pass a legislative decree (Decree 1097) that would have granted de facto amnesty to individuals from the military and police being 


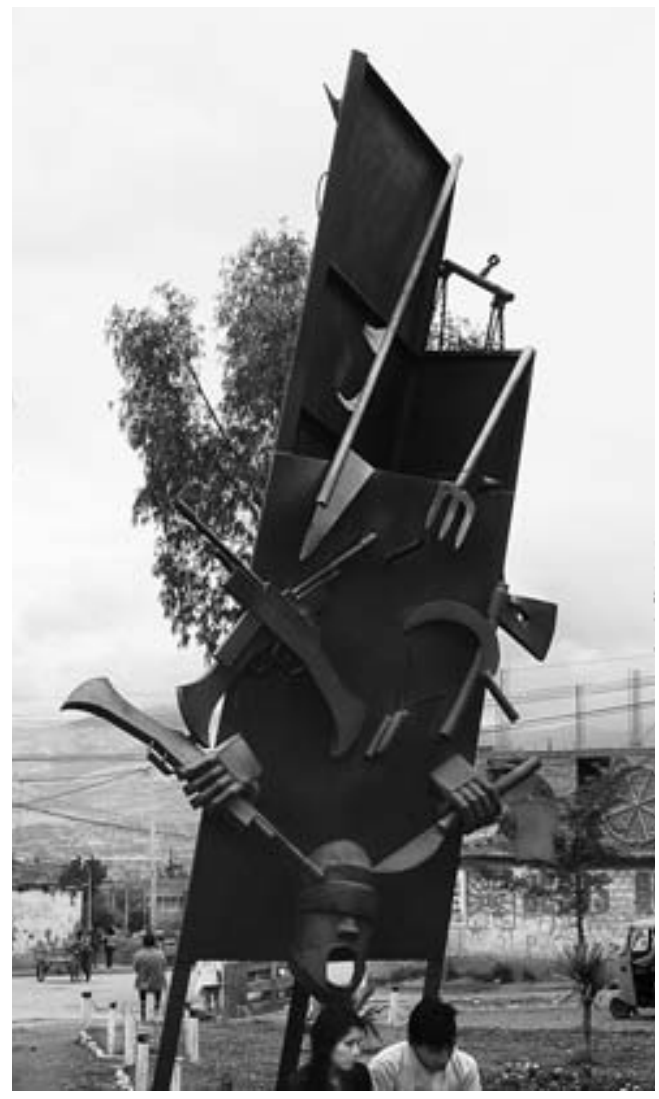

FIGURE I.1. Sculpture by Ayacuchan artist Wari Zárate in the "Memory Park" in front of the Museo de la Memoria of ANFASEP (the National Association of Kidnapped, Disappeared and Detained Relatives of Peru), Ayacucho. Photograph by María Eugenia Ulfe.

processed in Peruvian courts for human rights violations committed prior to 2003. ${ }^{57}$ In a similar spirit, on the ninth anniversary of the CVR's Final Report, President Ollanta Humala proposed a law that could have led to an eight-year prison term for "publicly expressing approval for, justifying, denying or minimizing" acts of terrorism committed by Shining Path. Congress adopted a watered down version of the proposed law. ${ }^{58}$ Other attempts to narrow public discussion over the recent past are the continuing acts of defacement against one of the few national memorial sites dedicated to the victims of the armed conflict, El Ojo que Llora. ${ }^{59}$ Reemerging conflict zones - such as those in the coca-producing Apurímac-Ene River Valley (VRAE) and mining sites like Conga in Northern Peru - and the state response to them spawn worrisome flashbacks 
14 / CYNTHIA E. MiLTON

FIGURE I.2. El Ojo que Llora (The Eye That Cries) memorial by Lika Mutal, Lima, defaced in September 2007. Photograph by Yael Rojas.

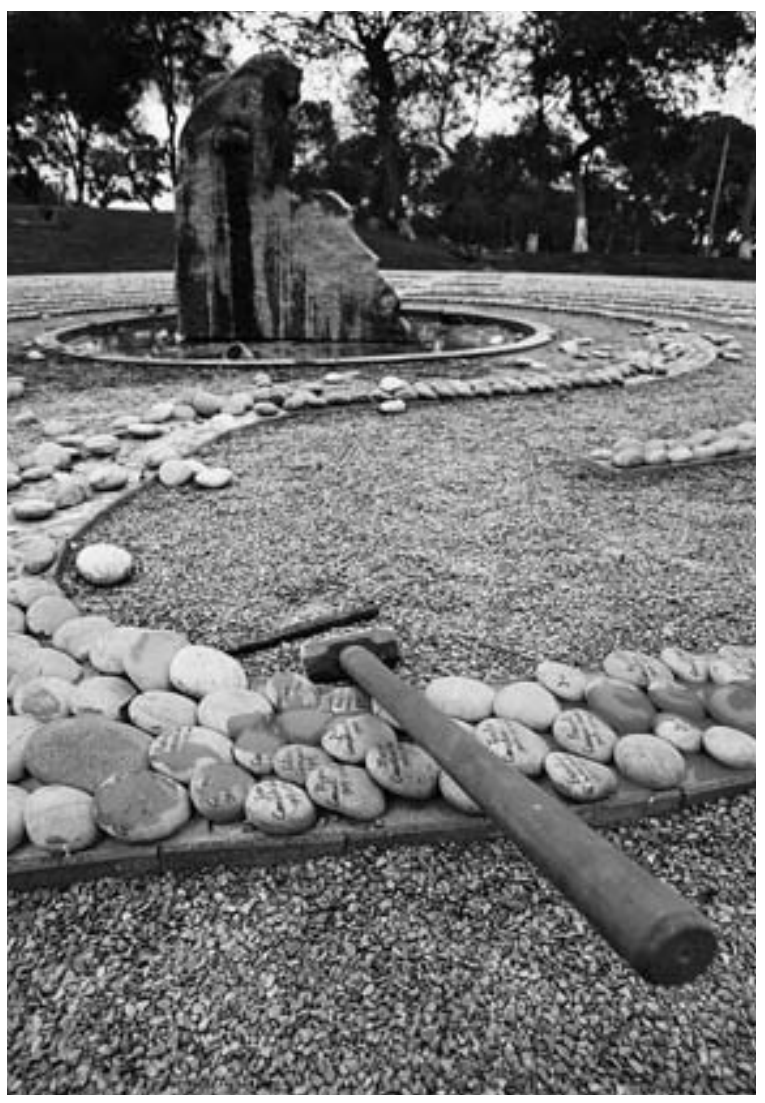

to the previous decades. ${ }^{60}$ That is, discussions of past violence sit uncomfortably alongside its legacies and continuities.

Truth-Telling by Other Means

Members of the CVR were aware of the importance of a cultural engagement with their findings beyond the publication of their Final Report. For the commission, visual representation played a central role in recounting a national narrative. According to Lerner, the use of audiovisual means to represent events necessitates a reconsideration of the relationship between seeing, knowledge, and power. A knowledge that arises from seeing calls on "intuition, senses, and emotions that are not necessarily irrational or unscientific, but rather expand the 
realm of our understanding." 61 The commission drew on established grassroots organizations and groups previously engaged in visual and artistic expression to promote a reflection on this past. For instance, the photography exhibition Yuyanapaq: In Order to Remember tried to appeal to civil society by displaying images familiar to the public, who had seen them in national newspapers. This artful curation of photographs interspersed among draped white gauzy sheets, housed in the crumbling ruins of a once affluent home, was meant to evoke the healing nation. ${ }^{62}$ The commission also employed the theatre troupe Yuyachkani, who had been actively making political and social critique since the late 1970s, to assist in informing Lima residents (Limeños) and highland communities of the commission's work and to encourage people to attend the public hearings. ${ }^{63}$

The CVR understood implicitly that the social opening accorded to it also extended to the public sphere more broadly-to nongovernmental and grassroots organizations, artistic groups, and individuals who had long expressed truth narratives and alternative jurisprudence in various forms. ${ }^{64}$ Truth-telling by other means than official inquiries flourished in the shade of the commission: for instance, in visual and performance art, memory sites, cinema, stories, humor, rumor, and song. ${ }^{65}$ The emergence of the commission signaled new opportunities to speak more openly about the past, giving important legitimacy to previously shunned or muted experiences. That is, "truth-telling" became part of the public domain, even at times at the national level, rather than an affair of individuals or groups.

The turn to art was not new. Art has been a means for contesting local abuses by authorities since the colonial period. One only has to think of Guaman Poma's depictions of the brutality of Spaniards and their impact on local cultures in his letter to the king as an example of early uses of art to speak truth to power. ${ }^{66}$ In the context of Peru's internal war, protest art has represented victims' realities since the early 1980 s. $^{67}$ Nevertheless, while local cultural forms of knowledge have always been present-for instance, in regional artistic traditions such as painted wooden retablos and tablas (painted panels) by Ayacuchano and Sarhua artists depicting violence, or the lyrics of folk songs (such as huaynos and pumpin) that give testimony to abandonment of natal lands and the disappearances of loved ones - such forms carried a new saliency and immediacy and attained public recognition at a national level after the launching of the CVR. 
Scholars of Peru and elsewhere are increasingly employing visual and audible representations in their analysis of the past. ${ }^{68} \mathrm{~A}$ turn toward including artbroadly defined here as cultural practices of aesthetic representation-in our investigations is all the more pressing for social groups for whom the written record may exclude or limit the expression of their experiences. Moreover, the written record is closely linked to the state and in many Peruvian highland communities the presence the state was weak, and the state itself may have been an aggressor. Thus, the essays in this book seek to trace some of the ways Peruvians utilize artistic means to describe their past, to understand it, and, in some sense, to bring about alternative justice, social repair, and a historical account.

As Gisela Cánepa has aptly noted, the Peruvian public sphere is exclusionary: Quechua, for instance, is not a language used in formal politics but is recognized as valid in the sphere of cultural production. ${ }^{69}$ One of the striking aspects of the artworks studied here is the way art may break down the barriers between formal politics and cultural production. That is, art can be both a forum for and a form of political expression. ${ }^{70}$ Indeed, spheres of representation are prominent in Peru's ongoing memory negotiations precisely because of the CVR's limited political impact and the commission's inability to pass on their findings as Peru's collective memory. ${ }^{71}$

It is difficult to situate neatly many of these visual representations that emerge from the political conflict within the field of art: are they "folk art," are they "popular art," are they "artisanal," are they "art"? Such efforts to label and categorize the work may merely reproduce the very hierarchies that are at the root of Peru's injustices. These artforms do not represent traditional versus modern epistemologies, nor are they fixed in time or place. They circulate in the global era, are sold to foreigners and collectors, and are displayed in private homes and in museums. ${ }^{72}$ The artists themselves travel and import other genres, such as Chilean arpilleras, to Peru. ${ }^{73}$ And the artists, like many of the survivors of violence, may have left their natal lands to rebuild their lives in regional capitals, Lima, or abroad. As William Rowe and Vivian Schelling have written, dichotomies of traditional/contemporary, rural-folk/urban-mass culture are no longer useful for analyzing artworks in general, principally because artistic media (mobile retablos, CDS, stories, paintings, the Internet, etc.) and their creators and performers easily move across geographical and social boundaries. ${ }^{74}$ 


\section{Bearing Witness through Creation: An Aesthetic Pursuit of Truth}

The essays that follow are only a selection of the many and various modes Peruvians are making use of to bear witness to their past: drawings, paintings, film, commemorative acts and sites, literature, music, performance, and regional artforms. Yet art as a means to bear witness, and in so doing shape contemporary cultural perceptions of the past, faces different challenges from the ones involved in nonartistic processes of historical clarification such as the CVR's writing of its Final Report and gathering of oral testimonies. Oral testimonies might hold a privileged place as evidence, since they are considered closer to the body of the sufferer, whereas art seems more distant and removed by dint of the process of production. ${ }^{75}$ In other words, the truth value of art (the truth or falsity of its depictions) is brought into question by the very medium of expression - the fact that art is born from the imagination. For art to bear witness to the past, it must be seen to possess authenticity and accuracy, exigencies perhaps unrealistic considering the passage of time and the act of creation.

Even when direct witnesses themselves generate art, does art witness accurately? Artworks are, after all, made, fabricated, created and are not direct traces or artifacts of the past. In our era when photographs are regarded by the distrustful eye of everyday viewers whereas they once held a privileged trust as direct observation - what Virginia Woolf described as "crude statement[s] of fact addressed to the eye" $e^{36}$ - today a created representation is under pressure to prove its veracity or factual worth, if its maker wishes it to serve as an expression of empirical knowledge. Can we "trust" art and images to recount the past? Yes and no. The vicissitudes of memory are present in artistic representations, just as they are in oral testimonies. The well-known debate over historical truths recounted by the psychologist Dori Laub is illustrative. In a testimony recorded in the Yale Holocaust Testimonies, a woman narrated her witnessing of a rebellion in Auschwitz, which, according to her recollection of events, resulted in the explosion of four chimneys. In fact, only one chimney was blown up, not all four. In this debate, scholars questioned the historical validity of this survivor's testimony because she remembered specific facts incorrectly. In contrast, Laub stressed the importance of respecting what the witness did not know (or could not know) and what she felt she "knew." 
veracity of Rigoberta Menchú's assisted autobiographical account of the Guatemalan genocide: she was taken to task for inconsistencies in her story and her accounts of events that she herself had not witnessed but recounted as through she had been present. ${ }^{78}$ Such strident demands for accuracy ignore her use of an inclusive "we" in her efforts to offer a collective testimony. Like that Auschwitz survivor, Rigoberta Menchú recounted what she knew as someone who had survived to tell what had happened. As Dori Laub argues, what is important is not the number of chimneys but "the reality of an unimaginable occurrence,"79 the breaking of the framework of the concentration camp so as to enable a narrative of "resistance, to the affirmation of survival, to the breakage of the frame of death." 80

Like oral testimonies, art may break old frameworks and build new ones. Because art is perhaps less tethered to the past and to facts than other media of truth-telling, art makes the "unimaginable" imaginable and provides new frames - marcos or cuadros - with which to construct new narratives. Art does not necessarily result in a singular narrative or even a coherent one. Rather, art may inscribe and promote multiple memories and meanings and implicitly counters the homogenizing tendencies of institutional memories. ${ }^{81}$ As Jelin and Longoni note, it is through words and images that the traces of horror overcome the limits of expression, even if incomplete or fragmented. It is through these traces that art becomes "the triumph of the word over the silence of absence." 82

Despite their importance, the essays in this book are not directly concerned with the truth value of art and the production of coherent narratives. Rather, the authors have at the heart of their common inquiry the multiplicity of interpretations and narratives, the myriad ways of seeing, knowing, and relating that are inscribed within the artforms under discussion. While most of the authors here explicitly or implicitly treat artistic representations as sources of evidence - of events ranging from specific experiences to generalized violence - they are aware of the pitfalls of memory, the molding that takes place as a result of an artist-survivor's intention to tell a story a certain way, the aesthetic of creative inspirations and impetus. Furthermore, many of the artworks studied here move beyond the tyranny of the war years and speak to historical truths that are not reducible to recent conflict alone, and thus to observable experience alone. Yet these artworks do recount experience: they are acts of witnessing 
and remembrance and as such are valid, indispensable sources of historical clarification.

Why are these artists creating and for whom? The potential audience may be central to these works' very production. The artists might hope that their works promote awareness, inspire empathy, and create a sense of obligation among viewers. Their representations demand that we look, that we bear witness in turn to the artists' acts of witnessing and remembrance. ${ }^{83}$ Art may seek to reach listeners and viewers otherwise distant from the experiences depicted and thus serve as catalysts for change in the audience's perception, knowledge, and actions. ${ }^{84}$ An artist's initial objective might be to preserve an account of the past for fear that it will disappear, as is suggested in the drawings of Edilberto Jiménez (chapter 2). In addition, artists might be creating for themselves, for members of their community, and/or for an external audience, for example a jury panel overseeing reenactments of battles between community members and Shining Path (chapter 7), judges of an arts competition (chapter 1), or cheering local peers at pumpin song contests (chapter 9). Artworks may reach national and international audiences, for example the wooden retablos by the Jiménez family (chapter 2), Palito Ortega's films, which are produced and shown in Ayacucho, Lima, and abroad (chapter 6), and Yuyachkani's Peruvian, European, and North American performances of Sin Título, Técnica Mixta (Untitled, Mixed Media) (chapter 8).

Some artists might create these representations also with the hope of recounting the past to someone as well as perhaps to seek some kind of justice or social repair. For instance, the artworks produced for the Rescate por la Memoria (Recovering/Rescuing Memory) contests speak of the past violence, the present poverty, the need to rebuild and move on. Almost all participants forward the cry, at least implicitly, of "Never Again," yet very few of the entries seem to propose reconciliation as a possibility (chapter 1). Ortega's more sociopolitical films point to the limits of the extant efforts at truth-telling; in particular, El rincón de los inocentes (The Innocents' Corner; filmed in 2005) offers an alternative narrative of the violence years and a critique of the CVR's missed opportunity to engage affected communities, what the historian Ponciano del Pino articulately calls "a metaphor for the nation's botched encounter" (chapter 6). Víctor Vich's study of La hora azul (The Blue Hour) suggests that the novel's author, a Lima resident, 
is trying to come to terms with his and his fellow Limeños' complicit role in the violence and the nature of subsequent generations' responsibility (chapter 4). The collective involved in the creation of Rupay addresses (and intends perhaps to teach) the same Limeño audience by illustrating the past via a patchwork of comic strips, art, testimony, newspaper clippings, and photographs (chapter 5). Similarly, Miguel Rubio and Yuyachkani's post-cvr production Sin Título, Técnica Mixta question the nationalistic impetus behind the jingoistic narrative of the late nineteenth-century War of the Pacific and seek to unravel this tale that was taught to several generations of Peruvian schoolchildren. The play shows how the social exclusions that resulted in Peru's earlier ignominious defeat lay at the heart of the later Shining Path conflict (chapter 8).

Many of the efforts discussed in this book focus on the highlands, Ayacucho in particular. This focus on Ayacucho reflects in part the rich cultural expressions of the region, and the concentration of NGOs especially in the conflict's wake. Ayacucho is where Shining Path chose to launch their "People's War" and accounts for 40 percent of the ensuing victims. Yet, it also reflects the predominance of Ayacucho in extant literature on the conflict as though the region represented the country as a whole, which it did not. In part, this emphasis on Ayacucho reveals the difficulties of reaching a more inclusive national reflection on the years of violence. As a new generation of scholars emerges, and as new studies are produced, the diverse histories of the conflict are more fully coming to light. ${ }^{85}$

Most of the artworks studied here are not from the perspective of those who speak on behalf of the "silenced," such as the work of some professional artists who present an aesthetic of suffering in the hope of documenting, educating, and preventing reoccurrence. ${ }^{86}$ Indeed, much of the literature on art and trauma to date focuses on the work of professional artists, many of whom hold international renown. Rather, the essays that follow do not make a distinction among the artworks along the lines of professional or "high" art versus other kinds. Rather, the focus is on the artist-survivors' representations: artwork produced by individuals and collectivities who lived through the experiences themselves and thus are direct witnesses, and who are engaging in art as a means "to give testimony" (dar testimonio) - a use of art that both I and Jonathan Ritter explore (chapters 1 and 9). As Palito Ortega Matute says in his interview, "having lived 


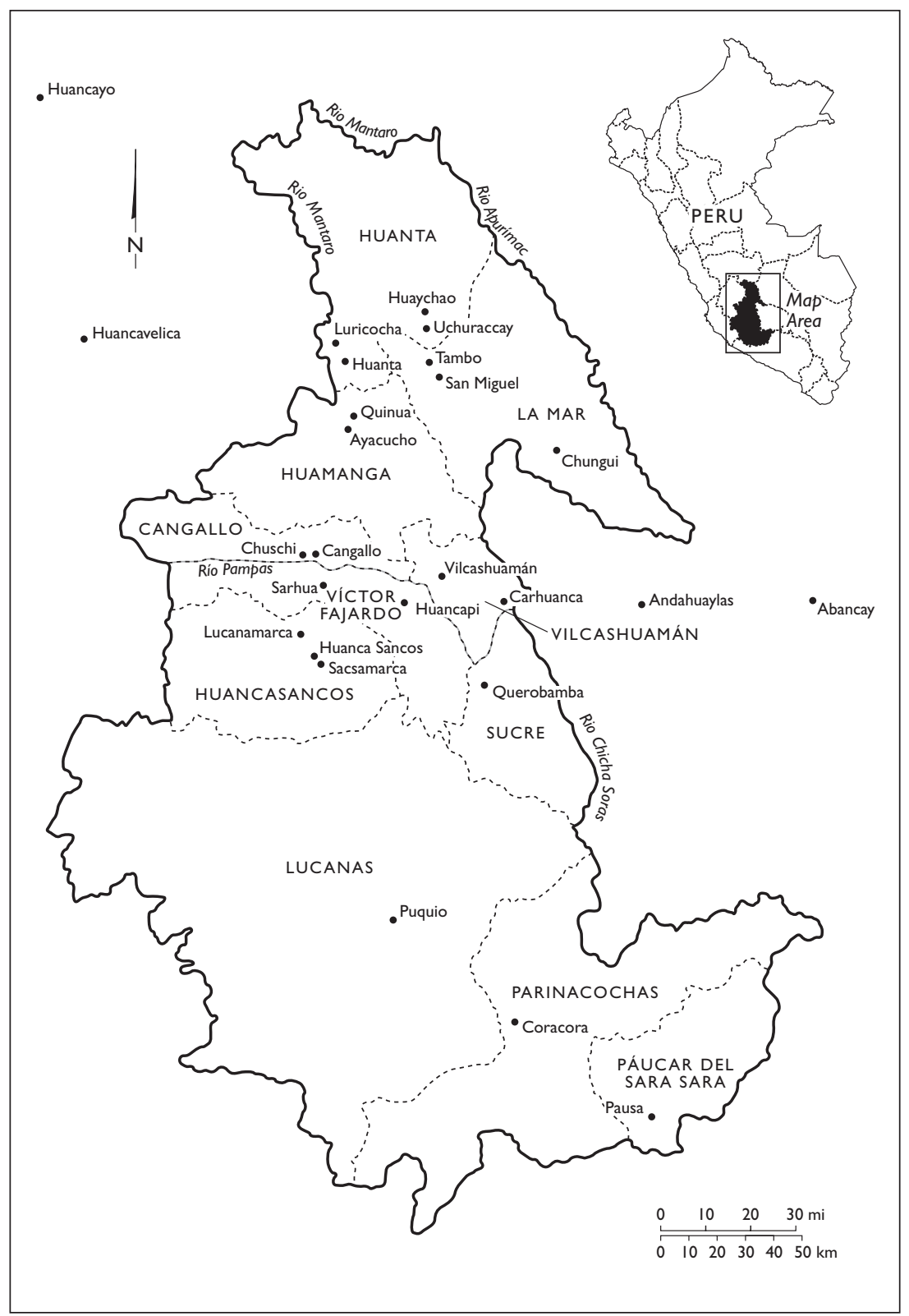

MAP 2. Department of Ayacucho. Cartography by Bill Nelson. 
this experience so closely myself, I think it gives me the power to tell these stories as they were. It is my duty. My conscience compels me to tell these stories without manipulation, without machination, without elaboration: this is the history that happened in Ayacucho" (chapter 6). Edilberto Jiménez's chapter presents an interesting overlap of testimonials/alteration: Jiménez is from Víctor Fajardo yet his work presented here is part of a larger collection of visual ethnographic accounts of distant Chungui (also in the department of Ayacucho). His drawings are a unique collaborative effort between himself as an artist, ethnographer, and regional neighbor who also witnessed the war's devastation and Chungui residents. The work of Lima-based artists such as Yuyachkani and the authors of La hora azul and Rupay may reflect their own experiences and feelings about the conflict years, perhaps a sense of collective remorse for having lived parallel lives, or a desire to understand what occurred during those years at a scale that was unconceivable to them prior to reading the CVR's Final Report. Almost all of the artists discussed in this book seem to wish to ignite empathy among those who did not directly experience the internal war for those who did. And perhaps by the former coming to understand the different subject positions of the latter, such empathy might bring about a kind of societal understanding, as unsettling as it may be to previously held perceptions of the past and individual responsibilities.

While the intentionality of the artists in their work is difficult to ascertain, even more illusive is audience reception. One cannot assume that these works are able to speak for themselves. What are the potential interpretations of these works? How are they received? In the absence of deep ethnographic observation of audience reception, the impact and understanding of these works by different social actors is difficult to access. As Deborah Poole and Isaías Rojas-Pérez rightly note in the case of the photography exhibit Yuyanapaq, displayed at the time of the CVR's publication of their Final Report, one cannot assume that viewers across regional, ethnic, and temporal divides will interpret images the same way. ${ }^{87}$ For instance, who bought and read post-CVR novels like La hora azul or the graphic novel Rupay? Who was likely to attend Yuyachkani's performance of Sin Título, Técnica Mixta? Are the metaphors found in the paintings of a Rescate por la Memoria contest obvious to only regional audiences or can national audiences 
comprehend them? Is there a difference between urban and rural reception of Ortega's films, as he suggests in his interview, such that urban audiences prefer films that directly address the conflict (what he calls "social interest films") and rural audiences prefer horror films based on mythical figures that indirectly hint at the years of violence? An important next step in using artistic representations as a means to historical clarification is to consider their impact on and uses by Peru's diverse audiences.

\section{Remembering through Art: the Limits of Empathy and Truth}

Art has the potential to help us, the audience, get closer to an understanding of what happened. Perhaps it is the only medium that allows us to hold in the same frame many of the complexities of this tragedy. Yet art is not bound to truth. It is a medium in which competing claims to the past emerge and are recounted. The stakes for cultural productions over the past are high. The images and narratives of the past presented through popular media may be more important for establishing collective or, potentially, a national memory of the past than even a truth commission, programs for reparations, and court cases. In Peru, cultural forms of (re)presenting are the present-day battleground for memory narratives. One of the reasons why Adorno's quote about poetry after Auschwitz remains salient today is that it points to the importance of culture in memory battles.

Whether a dung-adorned Madonna in a Brooklyn art gallery ${ }^{88}$ or a quiet memorial tucked away in a public park, art may provoke debate, all the more so when contested memories are in question. Art can elicit empathy, but it can also incite the opposite. ${ }^{89}$ Public art may disturb as well as commemorate. ${ }^{90}$ The uses and abuses of the memorial El Ojo que Llora in Lima's Campo de Marte (Champs de Mars) illustrate this dynamic well: while the father of a disappeared and a mother of a fallen soldier might find common solace at this memorial, and come to recognize each other's mutual suffering as parents, the memorial has also evoked visceral negations by vandals of victims and their families' right to remembrance. ${ }^{91}$ Art in public spaces does not necessarily promote a collective memory; indeed, art may highlight such memory's fragmentation. Yet El Ojo que Llora fulfills a common function of art: to promote reflection and discussion. Even at moments of great controversy, such as the memorial's defacement, 
efforts to shut down conversation only served to spark debate and thus further remembrance of the events that gave rise to this memorial site. ${ }^{92}$

It must also be acknowledged that not all art is necessarily "good" art in the sense of serving a public function of remembrance-that is, the uses rather than the abuses of a shared past. As editor of this compilation, I have chosen to highlight artistic endeavors that engage a human rights narrative in Peru and to place at center stage the multiple creative ways of seeing and recounting the past that contest forgetting or a "salvation" narrative. But I could have included artistic representations of salvation memory, as put forward by the "forces of order" and Peruvian neoliberal elites, or even memories as held among Shining Path militants. ${ }^{93}$ Indeed, such studies are necessary if we want to understand more fully the cultural realm of memory battles. ${ }^{94}$

In Peru, memory is not synonymous with human rights. "Memory" has become the trope used by individuals and groups who wish to promote a heroic narrative for the armed forces, and culture has become the battlefield where they contest the meaning of "memory" with those who fail to see their heroism. For instance, armed state actors construct their own "museums of memory." The military perform an annual reenactment of their rescue of hostages whom the MRTA held in the Japanese ambassador's home in $1997 .{ }^{95}$ Screenings are promoted in international film festivals of the movie Vidas Paralelas (Parallel Lives), which casts the military as untarnished heroes defending the vulnerable highlands people. ${ }^{96}$ These efforts to write and to promote through cultural media a different account of the war years offer an alternative (sometimes subtle) narrative to the one presented by the CVR: yes, this narrative seems to affirm, there was an atrocious political conflict that cost many innocent lives and was a national tragedy. Yet this narrative offers few lessons to be learned, other than not to repeat. The quasi-denialist rewriting of the war era reaffirms the role of the armed forces in it without seeking to reform the institution. This narrative pretends a democracy and a peace, without acknowledging the thousands of common graves on which Peruvians walk or the root causes of poverty, racism, and exclusion that perpetuate continued discontent.

It is this rewriting of the past that the artworks presented here are working against. As the Peruvian sociologist Félix Reátegui Carrillo has eloquently said 
in response to what he sees as widespread efforts to ignore Peru's fractured past, "Are we supposed to forget this? It is possible, but it impoverishes us and is obscene. Our public dialogue demands fiction. We need to be able to imagine in order to understand." 97

\section{Notes}

1. Ortega, Adiós Ayacucho.

2. The date for the end of the internal war changes depending on the importance given to specific events: on September 12, 1992, the leader of Shining Path, Abimael Guzmán, was captured, followed by several high-ranking members. In 1993, Guzmán proposed a "peace accord." In 1997, the Tupác Amaru Revolutionary Movement (MRTA) was eradicated after having held hostages for several months in the Japanese ambassador's residence. In 1999, the last member of the Shining Path leadership who had rejected the peace accord, Feliciano (Óscar Ramírez Durand), was captured. In 2000, Alberto Fujimori, who had become the symbol of authoritarian rule, resigned from the government. The continued presence of Shining Path - though greatly diminished-in the cocaproducing regions puts into question the idea of a clear "post"-Shining Path era.

3. The Peruvian Truth and Reconciliation Commission gave a specific figure, 69,280, as an estimate for the dead and disappeared caused by the internal armed conflict, based on statistical equations used in Guatemala and Kosovo. The range is between 61,007 and 77,552. See Comisión de la Verdad y Reconciliación (CVR), Informe final, annex 2, 13. The numbers for widows and children come from cvr, Hatun Willakuy, 385; on internal refugees see CVR, Hatun Willakuy, 386.

4. This project finds its genealogy in Steve Stern's call for a historical understanding of the episodic rendering of the internal conflict in "Beyond Enigma." A new generation of researchers has responded to the need to historicize Shining Path as something other than enigmatic or "out of step." See, for instance, dissertations by del Pino, "En busca del gobierno"”; Scarritt, "The Rattle of Burnt Bread"; Yezer, "Anxious Citizenship.” Published works include González, Unveiling Secrets of War in the Peruvian Andes; Heilman, Before the Shining Path; La Serna, The Corner of the Living; Ritter, We Bear Witness With Our Song; Taylor, Shining Path; and Theidon, Entre projímos and Intimate Enemies.

5. Adorno, Prisms, 34. On the decontextualization of Adorno's quote, see Huyssen, Present Pasts, 124, and on the various (mis)understandings of Adorno, see Friedlander, Probing the Limits of Representation, especially the introduction, and Rothberg, Multidirectional Memory, 112-113. For a thoughtful discussion of the importance of Adorno's dictum in a Latin American context, see Stern's afterword here.

6. See Koch, "The Aesthetic Transformation of the Image of the Unimaginable," 15. 
See also the juxtaposition of positions related to art in the shadow of the Holocaust in the works of H. G. Adler and Theodor Adorno in Franklin, "The Long View."

7. Studies of artistic representations after the Holocaust are many. To cite but a few: Alphen, Caught by History; Farmer, "Going Visual”; Friedlander, Probing the Limits of Representation; Hirsch, The Generation of Post-Memory; Huyssen, Present Pasts; LaCapra, History and Memory after Auschwitz; LaCapra, Writing History, Writing Trauma; Young, The Texture of Memory; and Young, At Memory's Edge; Zelizer, Visual Culture and the Holocaust.

8. Scarry, The Body in Pain; Friedlander, Probing the Limits of Representation, 5.

9. Stern, "Las paradojas de la verdad."

10. Arpilleras became part of a social movement against the dictatorship and internationally recognizable as human rights art. See Agosín, Tapestries of Hope, and Adams, "Art in Social Movements."

11. For instance, Jelin and Langland, Monumentos memoriales y marcas territoriales; Jelin and Longoni, Escrituras, imágenes y escenarios ante la represión; Gómez-Barris, Where Memory Dwells; Lazzara, Chile in Transition; Longoni, El Siluetazo; Masiello, The Art of Transition; Moodie, El Salvador in the Aftermath of Peace; Richard, Fracturas de la memoria.

12. Masiello, The Art of Transition, 7.

13. Sánchez and Escallón, "Memoria, imagen y duelo."

14. Maclear, Beclouded Visions, 24.

15. Japanese Broadcasting Corporation (NHK), Unforgettable Fire, 105.

16. Brett, Through Our Own Eyes; González, Unveiling Secrets of War in the Peruvian Andes; Milton, "At the Edge of the Peruvian Truth Commission"; Strassler, "Children as Witnesses of History in Post-Suharto Indonesia."

17. Scarry, The Body in Pain.

18. The incorporation of images and artforms into historians' and other social scientists' methodologies has gained credibility since the 1980 os debates on representations as historical documents that allows us to see the past from different perspectives to be taken into account with written and oral texts. For considerations of alternative sources and an expansion of historians' archives see Taylor, The Archive and the Repertoire; Stern, Remembering Pinochet's Chile; LaCapra, History and Memory after Auschwitz; Coronil, "Seeing History"; Gómez-Barris, Where Memory Dwells.

19. Greg Grandin and Thomas Klubock, in their "Editors' Introduction," situate truth commissions as a product of post-Cold War reckonings with the past that served political and institutional ends. On truth commissions see Hayner, Unspeakable Truths, and on extended periods of reckoning see Collins, Post-transitional Justice.

20. In 2003, the National Commission on Political Imprisonment and Torture, known as the Valech Commission, investigated human rights abuses against people who had survived the Pinochet dictatorship.

21. Article 3 of Decreto Supremo no. 065-2001-PCM. 
22. The CVR held eight public hearings with victims or family members, seven public assemblies, and five theme-based hearings (on subjects such as "antiterrorist" legislation, displaced persons, universities, women, and teaching). From these public hearings, the CVR gathered over four hundred testimonies about over three hundred cases of gross human rights violations.

23. Aguirre, “¿De quién son estas memorias?”

24. González, "The Peruvian Truth and Reconciliation Commission and the Challenge of Impunity," 70.

25. González, "The Contribution of the Peruvian Truth and Reconciliation Commission to Prosecutions," 56-57.

26. On this transitional period, see González, "The Peruvian Truth and Reconciliation Commission and the Challenge of Impunity," 71-75.

27. Degregori, "La palabra y la escucha," 95. "Transition by collapse"-whereby economic and military elite are less able to control the process - may more likely lead to criminal prosecutions. This was the case for Fujimori who in April 2009 received a twentyfive-year sentence for grave human rights violations, a feat that was attained in part because of the documentation gathered by the cvr. Burt, "Guilty as Charged."

28. While Quechua has been one of Peru's official languages since 1993, no program of studies in translation had been in place, and therefore there were no trained professionals as part of the commission. As Carlos Iván Degregori pointed out, long-standing socioeconomic, linguistic, and gender divides were recreated in the composition of the commission itself: among the CVR commissioners, only one spoke and understood Quechua, while another partially understood, thus maintaining a strong linguistic gap between the mainly middle-class, male (except for two women), Lima-based commissioners and the 75 percent Quechua- and other indigenous language-speaking victims. Carlos Iván Degregori, "Heridas abiertas, derechos esquivos," 82, n. 2.

29. Coxshall, "From the Peruvian Reconciliation Commission to Ethnography"; Milton, "At the Edge of the Peruvian Truth Commission"; Yezer, "Who Wants to Know?" 286, n. 10, 278.

30. González, "The Peruvian Truth and Reconciliation Commission and the Challenge of Impunity," 78.

31. The original composition included seven commissioners in 2001; President Toledo added another five commissioners and one observer. The retired air force general later distanced himself from the CVR's work, signing his name, with other retired military officers, on a public statement questioning the cvR's conclusions.

32. Regalado de Hurtado, Clío y Mnemósine. For early summaries of the CvR's work for an international audience, see González, "The Peruvian Truth and Reconciliation Commission and the Challenge of Impunity"; Sánchez, "Hatun Willakuy, importancia del relato en la política." 
33. Prior to the CVR's conclusions, NGOs, such as the Peruvian Coordinadora Nacional de Derechos Humanos, estimated around 25,00o victims of the internal conflict.

34. This expression comes from Heilman, Before the Shining Path; the theme of neglect and racism is also central in studies by de la Cadena, Indigenous Mestizos, and Méndez, The Plebeian Republic. The key earlier works on Shining Path are Manrique, El tiempo del miedo; Poole and Rénique, Peru; Stern, Shining and Other Paths; Degregori, El surgimiento de Sendero Luminoso; Degregori, Que difícil es ser Dios; Palmer, The Shining Path of Peru.

35. On the war and education, see García, Making Indigenous Citizens. Sixty-eight percent of victims had no secondary schooling, as opposed to the national average of 40 percent. Seventy-nine percent of victims were from rural regions, and 56 percent were agriculturalists (whereas in the 1993 census only 29 percent of Peruvians lived in rural regions, and of the national population only 28 percent were engaged in agriculture). CVR, "Conclusiones generales del Informe final de la CVR."

36. CvR, Hatun Willakuy, 52-55.

37. Women provided most of the testimonies before the CVR. CVR, Informe final, vol. 8,89 .

38. Lerner, La rebelión de la memoria, 147. Drinot also cites Lerner as advancing the historical argument of exclusion, The Allure of Labor, 237.

39. The remaining 7 percent of violence was attributed to unknown actors. Please note that these figures come from CVR, "Conclusiones generales del Informe final de la CVR" and from CVR, Informe final, vol. 2, 232. Even within the Final Report these numbers vary depending on the dataset analyzed. For instance, CVR, Informe final, vol. 2, 232 states that Shining Path was responsible for 53.68 percent of deaths and disappearances, the armed forces were responsible for 28.73 percent, and police forces 6.6 percent, versus annex 2, which attributes 46 percent Shining Path, 30 percent state agents, and 24 percent other actors and circumstances (self-defense groups, MRTA, paramilitaries, nonidentified agents, and others who died in combat) as responsible for deaths and disappearances; see CVR, Informe final, annex 2: 13, 17. In Hatun Willakuy, the violence committed by "state agents - the military and police" is grouped with self-defense groups (rondas) and paramilitary to account for 37 percent of deaths and disappearances, of which "the armed forces are responsible for a little more than three quarters of the cases"; see Hatun Willakuy, 10.

40. On the basis of his experience as a member of the Peruvian truth commission, Eduardo González describes the internal debates over the choice between seeking out "judicial truths," or evidence that could be used by courts, and "historical truths" that would help build a new narrative about the violence that would serve to undermine the Fujimori version that denied crimes committed. Without making a specific decision, the commission sought to prepare and provide as much information as possible for the courts to pursue; González, "The Contribution of the Peruvian Truth and Reconciliation Commission to Prosecutions," 61-63. 
41. CVR, "Conclusiones generales del Informe final de la CVR."

42. These categories of "salvation memory" versus "human rights memory" correspond roughly to Steve J. Stern's "heroic memory" and "dissident memory" in Stern, Remembering Pinochet's Chile. Paulo Drinot extrapolates two key versions in circulation in the national discourse of why the violence occurred: one camp sees Shining Path as singly responsible for the violence because Senderistas are inherently violent; the other camp sees the most recent eruption of violence as an extension of the structural violence that is inherent in Peruvian society and that had given rise to Shining Path and the exacerbating response by the state, elite and middle-class citizens. Drinot, "For Whom the Eye Cries," 24-27. See also Theidon, "Disarming the Subject," and Degregori, "La palabra y la escucha."

43. One example of several publication forwarding this salvation memory is retired coronel Morán Reyna's Complot contra los militares: Las falcedades de la C.V.R., a book published in 2006 in defense of "my comrades who acted legally, and today are obligated to prove their innocence" (n.p.).

44. The use of the narrative tropes borrowed from the Southern Cone countriesdictatorship to democracy, and dirty war-can be misleading in the Peruvian context. The Peruvian experience is not one of redemption - from dictatorship to democracy (though there is a bit of this) and does not involve a "dirty war" waged by an authoritarian state against its civilians, since most of the violence happened during democratically elected governments (except for the period of Fujimori's "self-coup" by which he dissolved Congress). In Peru there was initially a real threat from armed groups; thus, at least until the capture of Abimael Guzmán and the later putting down of the MRTA, the state did not need to invent or exaggerate an armed opposition. Nevertheless, the armed forces did act in ways that replicated other countries' dirty war tactics against fellow citizens. For a discussion of the meaning of "dirty war" see Stern's afterword here and Rénique, "'People's War,' 'Dirty War."”

45. Drinot, "For Whom the Eye Cries," 26.

46. Milton, "At the Edge of the Peruvian Truth Commission," 13-15.

47. González, "The Contribution of the Peruvian Truth and Reconciliation Commission to Prosecutions," 85, 91-92. The political scientist Jo-Marie Burt, who has been closely monitoring the cases before the Peruvian judiciary, has noticed that the number of prosecutions with sentences have dropped radically since the initial successes of holding perpetrators to account that culminated in the sentencing of Fujimori in 2009. Burt, "The Paradoxes of Accountability."

48. Much immediate post-CVR debate asserted that the statistics inflated the military responsibility for death and disappearance. Yet, in the ten years since the CVR, there seems to be a general feeling among researchers and human rights groups that the scale of the military violence was underestimated in the Final Report. This latter observation 
is based on my conversations with several researchers and members of Peruvian NGOs, as well as my own research into representations of the violence, discussed in my chapter here. See also Leiby's recoding of CVR testimonies in "Digging in the Archives," 84, 91.

49. Degregori, "Heridas abiertas, derechos esquivos," 84.

50. The CVR printed twenty thousand copies of Hatun Willakuy (2004), a 477-page abbreviated version of the nine volumes and the annexes of the Final Report.

51. This expression comes from Laplante, "The Peruvian Truth Commission's Historical Memory Project," 444-445.

52. Wilde, "Irruptions of Memory."

53. González, "Scarf of Hope as a Warm and Performative Memorial for the Disappeared in Peru."

54. Website available at http://arteporlamemoria.wordpress.com, accessed July 10, 2013.

55. As one of the few memorial sites designed for a national audience, El Ojo que Llora in Lima has received significant attention from families of victims and other stakeholders, from vandals, from politicians, and from academics. See Drinot, "For Whom the Eye Cries," Hite, Politics and the Art of Commemoration, 42-62; Milton, "Defacing Memory," and Moraña, "El Ojo que Llora."

56. Milton and Ulfe, "Promoting Peru"; Weissert, "Entre dos fuegos"; Feldman, "Exhibiting Conflict."

57. Jo-Marie Burt, "1097: La nueva cara de impunidad" (1097: the new face of impunity), NoticiasSER, August 9, 2010, www.noticiasser.pe, accessed July 15, 2013, and unknown author, "La ONU advirtió que el DL 1097 tiende a que violadores de derechos humanos queden impunes," El Comercio, September 8, 2010.

58. Human Rights Watch, "Peru: Reject 'Terrorism Denial' Law," April 9, 2012, http:// www.hrw.org/news/2013/o4/o9/peru-reject-terrorism-denial-law, accessed May 23, 2013.

59. While aspiring to be a memorial for the nation, it was not a national government project. El Ojo que Llora is a private initiative by the artist and architect with support of NGOS and municipal government.

6o. On coca production and links to Shining Path in the Upper Huallaga Valley, see Kernaghan, Coca's Gone.

61. The CVR published the photography exhibition as a book Yuyanapaq: Para Recordar.

62. Milton and Ulfe, "Promoting Peru," 213-216; Lane, "Spatial Truth and Reconciliation."

63. On the role of Yuyachkani in contesting violence during the war years and in reconstruction during the post-conflict period, see Taylor, The Archive and the Repertoire, 190-211; and A'ness, "Resisting Amnesia." See also Garza's chapter here.

64. Laplante and Theidon, "Truth with Consequences."

65. These eight modes of unofficial "truth-telling" are discussed for various countries 
(such as South Africa, Guatemala, Chile, Argentina, Cambodia, the Philippines, Thailand, and former Yugoslavia) in Bilbija et al., The Art of Truth-Telling about Authoritarian Rule. See also Jelin and Longoni, Escrituras, imágenes y scenarios ante la represión; Bickford, "Unofficial Truth Projects."

66. In his book on Peruvian "popular art," the art historian Pablo Macera includes one chapter on protest art, a study of sixteenth-century mates burilados (painted gourds) that depict scenes from the conquest. Macera, "El mate de la Conquista: ¿Arte protesta?" See various protest art from the 1980 in Billie Jean Isbell's Andean Collection at Cornell University Library, http://isbellandes.library.cornell.edu/protest.html, accessed July 10, 2013.

67. Isbell, "Violence in Peru," 287. Professional artists such as Juan Acevedo, Carlos Tovar, Claudia Coca, Natalia Iguiñez, Claudio Jiménez Quispe, Luz Letts, Alfredo Márquez, Claudia Martínez Garay, Jorge Miyagui, Cuco Morales, Piero Quijano, Santiago Quintanilla, Hebert Rodríguez, Eduardo Tokeshi, Ángel Valdez, and Ricardo Wiesse are just some of the many Peruvian artists who made protest art directed specifically at the war years. Some of their works, and those of other artists, appear with reflections on the role of art in remembering the violence in the Instituto de Estudios Peruanos, Revista Argumentos 3, no. 4 (2009), esp. 30-51. Peruvian curators, most notably Gustavo Buntinx, have built several exhibitions addressing Peru's conflict: for instance, his exhibitions Mallki: La exhumación simbólica del arte peruano, 1980-200o (Mallki: Symbolic Exhumation of Peruvian Art, 1980-200o), 2002; Carne viva: Partes de guerra 1980-2003 (Raw Flesh: Fragments of War 1980-2003), 2003; and País del mañana: Utopía y ruina en la guerra civil peruana, 1980-200o (Country of Tomorrow: Utopia and Ruin in the Peruvian Civil War, 1980-2000), 2004. Buntinx also directs the Micromuseo, www.micromuseo. org.pe, accessed July 10, 2013, an alternative museum project that holds small-scale exhibitions, many of which have addressed specific events during the conflict (such as the bombing on Tarata Street and the killing of nine students and one professor from La Cantuta University).

68. In addition to the chapters by Ulfe and Ritter here, see Lemlij and Millones, Las tablas de Sarhua; González, Unveiling Secrets of War in the Peruvian Andes; Ritter, "Complementary Discourses of Truth and Memory" and We Bear Witness With Our Song; Saona, "The Knowledge that Comes from Seeing"; Vich, El caníbal es otro, Ubilluz, Hibbet, and Vich, Contra el sueño de los justos, and the work of several emerging scholars. On artforms as witnessing history, see Burke, Eyewitnessing; and Loew, "Traumatic Identity in Contemporary Catalan Testimonies," 24. See also note 11.

69. Cánepa, "The Public Sphere and Cultural Rights."

70. Take for instance the massive civil society participation in the 2000 performance of "lava la bandera" (washing the flag) whereby participants washed corruption out of the Peruvian flag, thus cleaning the nation. Vich, "Lava la bandera." 
71. Drinot, "For Whom the Eye Cries," 20.

72. Olga González's study of Piraq Causa, a set of Sarhua tablas in the private collection of Peter Gaupp, illustrates well how art travels across boarders and media. Gaupp commissioned the works, which were made in a Lima workshop by artists who had fled the violence, and moved the works to his home in Costa Rica. The works have been exhibited abroad. González brought the tablas back to the artists' home community of Sarhua as photocopies. Now the tablas are reproduced in color plates in her book Unveiling the Secrets of War in the Peruvian Andes. Anyone can order this book through the Internet.

73. On the importation of Chilean arpillera techniques by women's groups in Peru, see Isbell, "Violence in Peru," 287.

74 Rowe and Schelling, Memory and Modernity.

75. Part of our mistrust of art and images is the primacy that we have granted the written and spoken word in the act of bearing witness. As Guerin and Hallas have pointed out, "it is true that words are more frequently considered closer to the communication of feeling and experience. Words, particularly those of oral testimony, are still connected to the body of the sufferer while the material image implies a separation (spatial, temporal or both) from that which it captures." Guerin and Hallas, The Image and the Witness, 7.

76. Cited in Sontag, Regarding the Pain of Others, 26.

77. Laub, "Bearing Witness or the Vicissitudes of Listening," 61.

78. Arias, The Rigoberta Menchú Controversy.

79. Laub, "Bearing Witness or the Vicissitudes of Listening," 6o.

8o. Laub, "Bearing Witness or the Vicissitudes of Listening," 62. The veracity of testimonio is broached differently in subsequent efforts by scholars to offer more participative coauthored testimonials, such as that between Rosa Isolde Reuque Paillalef and Florencia Mallon in When a Flower Is Reborn. Nevertheless, scholars might still try to question testimoniantes about silences in their remembrances, thus challenging what they state as knowing. See for instance, Lazzara, Luz Arce and Pinochet's Chile, 78-80, 90-91.

81. Multiple narratives might be especially present in the case of public art such as monuments and memorial sites whereby art addresses a heterogeneous audience. See Young, The Texture of Memory, 6; and Minow, Between Vengeance and Forgiveness, 138-139.

82. Jelin and Longoni, Escrituras, imágenes y escenarios ante la represión, xvii-xviii.

83. On various efforts to curate pasts as promoting witnessing, see Lehrer and Milton, "Witnesses to Witnessing."

84. Isbell refers to the "dialogic breakthrough" that takes place between performers and listeners; see "Violence in Peru," 284.

85. For instance, the Asháninka, though singled out by the CVR as a having had a particular experience of the political conflict, often slip out of larger conversations about the war years. The Instituto de Estudios Peruanos's Memory Group (Grupo Memoria) 
promotes regional studies by young scholars. See www.iep.org.pe/grupomemoria.html, accessed July 10, 2013. See also Rénique, La batalla por Puno.

86. Many professional artists not discussed here witnessed and experienced the war years directly. An insightful documentary, Against the Grain: An Artist's Survival Guide to Peru by the Japanese-American director Ann Kaneko examines the art and practices of art-making during and after the war years through the work of four Lima-based artists: Claudio Jiménez Quispe (originally from Ayacucho), Alfredo Márquez, Eduardo Tokeshi, and Natalia Iguíñiz.

87. Poole and Rojas-Pérez, "Memories of Reconciliation."

88. The work mentioned here is by British artist Chris Ofili, The Holy Virgin Mary (1996).

89. While important for reaching an understanding, empathy can also lead to overidentification. LaCapra, Writing Trauma, Writing History, esp. chap. 3; Bennett, Empathetic Vision.

90. Minow, Between Vengeance and Forgiveness, 142.

91. Hite, Politics and the Art of Commemoration, 54-55.

92. Milton, "Defacing Memory."

93. An entryway into these Shining Path memories is through the testimonies gathered and analyzed by Rénique in La voluntad encarcelada.

94. In this regard, the publication by the military of their account of the internal conflict, En Honor a la Verdad: Versión del Ejército sobre su participación en la defensa del sistema democrático contra las organizaciones terroristas (In Honour of the Truth: The Army's Version of Its Participation in the Defence of Democracy Against Terrorist Organizations), with other sources such as memoires by state actors, are useful for the elucidation of different versions of this shared past. The recent memoire by Lurgio Gavilán indicates the difficulty of separating memories neatly into categories of those of a hero/ perpetrator/victim, among others. Gavilán recounts his childhood as a Senderista, then adolescence as a soldier - both periods in which he inflicted harm upon others and in which he himself seemed to suffer - and ends with his adult years as a Franciscan monk turned anthropologist.

95. To mark the fifteenth anniversary of the April 22, 1997, liberation of MRTA prisoners - and the death of all the MRTA hostage-takers - a special homage was performed and broadcast on state television, in addition to the annual reenactment of the rescue, known as "Chavín de Huántar." For the 2012 homage, in the presence of Japanese residents, former hostages, and state representatives, the military reenacted the successful rescue with explosives, gunfire, and much drama. The case of the extrajudicial killings of MRTA members in the state operation "Chavín de Huántar" is presently before the Inter-American Court of Human Rights. For a recent foray into state armed actors' 
34 / CYNTHia E. Milton

uses of culture, in particular museum exhibitions and historical reenactment, see Milton, "Curating Memories of Armed State Actors in Peru's Era of Transitional Justice." 96. Milton, "Parallel Lies?" On the armed forces and their memories in the face of human rights discourses, see Hershberg and Agüero, Memorias militares sobre la repression en el Cono Sur.

97. Reátegui Carrillo, "Violencia y ficción," 449. 
PART ONE / VISUAL REPRESENTATIONS OF RECENT PASTS 



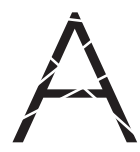
lone woman wipes tears from her eyes with one hand. In her other hand she absentmindedly holds a wool spinner. One of her shoes is broken. Her back is slightly hunched forward, not from the weight of her satchel but from her sadness. This drawing, done in pastel watercolors, is entitled Behind the Shadow of Pain (Tras la sombra del dolor, fig. 1.1). ${ }^{1}$ There are no scenes of violence, yet her pain is visible to us. Such is the capacity of art to recount experience.

Visual art offers a powerful means of nonverbal expression. Art is also one of the many modes by which individuals and groups forge acts of remembrance. Through a consideration of a corpus of artistic works that emerged around the time of the Peruvian Truth and Reconciliation Commission (Comisión de la Verdad y Reconciliación; CVR), this chapter explores the ways that art recounts the years of conflict and what pasts are recounted. In preparation for the release of the commission's findings, and later as part of the symbolic reparations promoted by the CVR, a series of art contests entitled Rescate por la Memoria (Recovering/Rescuing Memory) were held in the Peruvian highland departments of Ayacucho (2003, 2004) and Huancavelica (2004). ${ }^{2}$ A consortium of NGOs called Colectivo Yuyarisun (We Are Remembering) organized the initial contest in an effort to spread awareness of human rights and to establish a collective memory project. ${ }^{3}$ For the initial contest, held in the department of Ayacucho in 2003 just prior to the publication of the CVR's Final Report, members of Yuyarisun traveled to community fairs in eight provinces of Ayacucho, where they invited youth and adults to express through art their thoughts about truth, justice, reparation, 
FIGURE 1.1. Behind the Shadow of Pain (Tras la sombra del dolor), by Luis Cuba Arango (Pampamarca, Vinchos). Reprinted with permission from Colectivo Yuyarisun, Rescate por la memoria, 17.

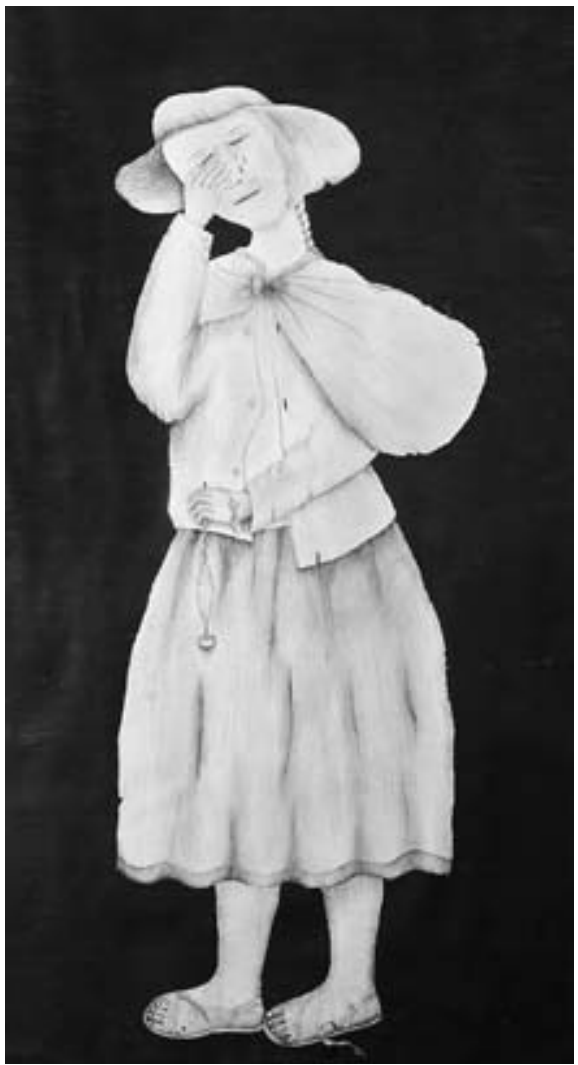

reconciliation, and the internal war years. Posters and radio slots advertised this contest and those that followed. For the first contest, a total of 175 different works were submitted in the categories of poetry, stories (both comics and short stories), song, and paintings. In response to the initial contest's success, on the request of communities, and with the support of international funds, the Asociación de Servicios Educativos Rurales (Association of Rural Educational Services; SER) repeated the art contests the following year in urban Ayacucho (receiving 301 entries) and in the department of Huancavelica (with 129 entries). Subsequent spin-off regional art contests were held in Sacsamarca and Lucanamarca. ${ }^{4}$

The over six hundred artistic works submitted for the Rescate por la Memoria (Recovering/Rescuing Memory) contests in Ayacucho (2003 and 2004) and Huancavelica (2004) depict the experiences of people in regions directly affected by 
the conflict. In this chapter, the focus is on the painted drawings (dibujos pintados) and comic strips (historietas). Much of their content supports the CVR's conclusions in the Final Report. Yet the testimonial framing and the visual impact of these works recount the past in a different way and perhaps in so doing offer divergent perspectives of "truth." The images of truth presented in the contests emphasize general collective memories of artists' communities that resonate with the CVR's findings, while also revealing specific individual and community experiences of suffering as they affected victims along ethnic, gender, and generational lines. The images further challenge the notion of possible national reconciliation as heralded by the CVR, and make clear demands for the recognition of the continuing plight of those who live in former conflict zones. And it is the memories of childhood at a time of great uncertainty, atrocity, and hardship that are most often brought to light in these testimonial artworks.

\section{Human Rights Art in the Highlands}

Art as a means to recount experience has long been cultivated by government and human rights groups, who have often employed different artistic media to encourage local residents to depict their daily life. For instance, in the 1990s, agronomists asked peasants to map out their hamlets and agricultural practices in order to better provide them development assistance. ${ }^{5} \mathrm{~A}$ decade later NGOs, such as the Institute for the Investigation and Promotion of Development and Peace in Ayacucho, used similar practices to encourage participation in elections and as a way for residents to indicate potential problems such as excessive distance between their homes and voting stations. Some early maps were "drawn" by placing beans; later approaches used pencils and paper. In addition, NGOs improvised plays with residents in order to better understand communities' relations and needs. In an attempt to prepare individuals and groups affected by the internal conflict to testify before the CVR, members of SER convened workshops with community members and leaders in which they mapped scenes of violence onto large sheets of white paper using colorful felt pens; only a few of the original maps remain. A second workshop was held after the CVR as a means to record this information as a collective memory project. ${ }^{6}$

Encouraging the description of community life through art in Peru dates back to at least 1984, when various NGOs, with the support of Oxfam, held a National 
Peasant Drawing and Painting Contest (Concurso Nacional de Dibujo y Pintura Campesina) for rural folk to illustrate daily life. ${ }^{7}$ The first contest was held on June 24, the Día del Campesino (Day of the Peasant; also the Día de San Juan). A contest was held almost every year until 1996, when funds ran out; the ten contests generated 7,004 artworks. One objective was to promote awareness of and respect for diverse cultures in Peru. During the years when these contests took place there was a sense that a "creative meeting" with the "peasant population" was needed at a time of extreme inflation, growing poverty, and escalating violence. ${ }^{8}$ A portion of this collection, around 3,500 works, is now held at the Centro Cultural de San Marcos, where some have undergone a process of restoration and digitalization. ${ }^{9}$

The decision whether to privilege drawing and painting in the national contests over more local, long-standing artforms - for instance retablos, mates burilados (carved gourds), and tablas - posed some concern for the organizers of the national contests. They were aware that the use of paper and pencil was connected to outside culture, that of the "conquistadores," and other artforms such as textiles and painted gourds were more established modes of highland cultural expression. ${ }^{10}$ Indeed, one of the consequences of these art contests and other NGO workshops may have been the teaching of occidental methods of representation and narrative structure, such that the form of expression influenced the content. Furthermore, while such technologies of expression might solve the problem of how to enable auto-representation, the fact that such artworks are produced for specific consumers might in fact lead to the exoticization of participants and their work. ${ }^{11}$

Each year brought greater participation in the national art contest, despite economic crisis and political violence. ${ }^{12}$ Organizers ran announcements on the radio, on programs such as Tierra fecunda (Fertile Earth), and circulated posters publicizing the contest. ${ }^{13}$ The participants were of all ages, came from poor regions, and worked in humble professions: they were small-scale farmers, laborers, homemakers, carpenters, artisans, pastors, drivers, itinerant salespeople, domestic servants, small-scale businesspeople, tailors, herders, knife sharpeners, bricklayers, porters, fishermen, washerwomen, and green grocers. ${ }^{14}$ Though prizes were awarded in various categories (such as for materials used by artists), ${ }^{15}$ the motivating factor for contestants seemed to be more than just the 
chance of winning, but offered the opportunity to communicate their knowledge, customs, problems, and hopes. ${ }^{16}$ According to one participant from Ancash, "I want to make known the crucial moments through which we are living in our province and in Peru in general." ${ }^{17}$

The National Peasant Drawing and Painting Contests were predecessors of the Rescate por la Memoria (Recovering/Rescuing Memory) contests, which were held during the following decade in the postwar highlands. Indeed, some of the coordinating organizations and individual members overlapped, including SER and Oxfam. However, while the earlier series of contests aimed to encourage rural folk to depict their social, historical, and cultural realities (including daily life, fiestas, changes in communities, personal dramas, and political violence), the Rescate por la Memoria contests, held during and after the truth commission's work, focused specifically on the internal war. In the earlier contests, none of the entries that dealt with the theme of political violence had been awarded prizes, apparently because they did not meet the aesthetic criteria of the judges. ${ }^{18}$ In the Rescate por la Memoria contests, the winning entries were chosen not only for their aesthetic quality but also for their "vision of events during the armed conflict." 19

\section{Art as Testimony}

In the context of the CVR's truth-seeking, the forum of an art contest changed from a means of describing daily life in general to that of providing testimonies of violence specifically. In part the shift reflects the evolving objectives of the participating NGOs from promotion of development policies to promotion of human rights. The shift also may be part of a global trend in post-conflict transitional justice practices whereby art is increasingly employed as a tool in peace building, healing, and reconciliation. ${ }^{20}$

The Rescate por la Memoria contest pieces implicitly combine the primary experience of trauma with testimony. While there is a field of art studies that addresses traumatic memory, it is not clear from these art contests whether the intention was to use art as a medium for overcoming trauma. The title of the contests suggests a possible awareness of a psychological condition or practice, since "rescate por la memoria" denotes "recovery of memory" (as well as "reclamation" or "rescue" of memory). However, it does not seem that the contest 
organizers had any intention to retrieve buried or suppressed memories, such as childhood memories that come to light in adulthood. Rather, the entries suggest that these memories were never buried but were un(der)acknowledged by general Peruvian society and possibly at risk of nonrecognition.

A subtle distinction needs to be made between what visual studies and trauma studies consider testimonial art and the artworks considered here. ${ }^{21}$ These two domains consider literature and formal art-that is, art done by professional artists - as a means of bearing witness to an event and working through an individual or collective traumatic experience, for example the works of Marcelo Brodsky in Argentina or Doris Salcedo in Colombia. ${ }^{22}$ The Rescate por la Memoria contest works differ, not only because the participants are not professional artists for the most part but also because their aim does not appear to be to work through a traumatic experience (though the coordinators of the contests might have hoped for this outcome). Rather, the contest entries suggest an urgency to bear witness in the sense of testimonio, that of denouncing or condemning injustices (though professional artists may intend this as well). ${ }^{23}$ In their entries, participants attest to what they directly witnessed and how their lives and communities have changed as a result, and they structure these memories into artistic narratives. Because of this emphasis on bearing witness and narrating in the face of indifference and injustice, the artforms studied here are similar to hibakusha testimonial art, that is, art by survivors of the atomic bombings of Hiroshima and Nagasaki whose recounting of experience was prohibited by the postwar state. Thousands of paintings and drawings, many on small scraps of paper, depict scenes and effects of atomic bombing. ${ }^{24}$ Similarly, the emphasis in the Rescate por la Memoria contest works seems to be placed on the testimoniothe function of art is to recount and denounce experiences to specific audiences: the judges who evaluate the entries, the bystander community who were neither direct victims nor perpetrators of violence, those who govern, and future generations. ${ }^{25}$

How subsequent viewers, whether judges of the contest, Peruvians, or researchers, interpret these works necessarily changes the meaning of this art's testimonial function. That is, judges (made up of local artists and musicians, NGO members, and academics) might assess the testimonial content and the aesthetic quality. ${ }^{26}$ A Peruvian viewing these works online or as part of an exhibition might receive 
them as secondary witnesses to the initial acts. And a researcher, like me, might try to "read" these works for their testimonial content and narrative constructions of the past.

There are constraints, however, both to critically evaluating these works as art and to using them as documentary evidence. As John Berger has written in reference to hibakusha art, one cannot critique the artistic qualities of these haunting images, for "one does not musically analyse screams." ${ }^{27}$ There are also limits to analyzing art as documents that are authentic and accurate, a requirement that artistic images be somehow tethered to truth. ${ }^{28}$ The murkiness of memory and time, and of the temporal political present in which the images have been produced, all contribute to the distancing of artistic images from an uncompromised reality. One should be particularly careful with any assumption that these images and the artists represent a "real subaltern voice," as though marginalized groups are somehow closer to reality with their "blunt, coarse, obvious, physical" depictions, and that only urban, educated classes alone hold the capacity for aesthetic artifice. ${ }^{29}$ Indeed, central to interpreting these paintings is the tension created by the origin of their production. ${ }^{30}$ These were not spontaneous works. Rather, the contributors were responding to a call for artwork on the theme of the internal war in contests sponsored by NGOs.

Furthermore, there is also the problem of interpreting distinct cultural and historical referents: it is difficult to skillfully read intention into symbolic works without a certain level of cultural immersion. ${ }^{31}$ The symbol of the condor is a good example of the limits of interpretation. A condor in a painting might be a representation of a huge carrion bird. Or it could represent a military helicopter, or something else altogether. A select group of the armed forces wore black shirts with an image of a condor on their chests. According to Arianna Cecconi, some highland campesinos dreamt of condors just prior to the arrival of military helicopters, premonitions of the violence to come. ${ }^{32}$ Several artists make reference to the same event by including depictions of helicopters dropping bombs: military incursions into Parco Chacapunco in 1986. Yet, the many appearances of helicopters in the dibujos pintados remain curious. As Ramón Pajuelo also notes in reference to the National Peasant Drawing and Painting Contests, helicopters were relatively rare in Ayacucho. ${ }^{33}$ The repeated presence of the helicopter in these paintings thus may highlight the brutality of the military, 
and the constant fear of their sudden arrival. Similarly, the presence of the Apu (mountain spirit) in these artworks might hold different meanings: according to Cecconi, for residents in Chihua and Contay the Apu "can appear in dreams to protect or to punish, to bring wealth or to make an animal disappear, to seduce or to bring illness" and may take many forms such as a landowner, a soldier, an animal or a condor, among other powerful entities. In the Waswantu plateau of Víctor Fajardo (studied by Jonathan Ritter here), one resident notes that Apus "are witnesses to our suffering, to what has happened to the population." 34

Despite the possible dangers of misinterpretation and overestimation of these graphic works' ability to represent "reality," I wish to read them for their testimonial narrative (the representation and the content) without challenging entirely the motives of the witness-artists or the completeness of their memory and depiction. Indeed, it is the framing and rendering of their testimonial narratives for a specific audience and the tensions over their production and meaning that are salient to their memorial, communicative, academic, and aesthetic value. ${ }^{35}$ Yet, by analyzing the testimonial narrative, I do not wish to entirely strip away the sensual aspects of art or its ability to transmit meaning and emotion. For while art as a mode of communication might depict events with some accuracy, art can also "bring other eyes and hearts closer." 36

\section{Testimonial Framing}

The Rescate por la Memoria contest entries depict and denounce the years of violence and demand alleviation from continued hardship. Participants recount their stories. They do so by way of various framing techniques. In these works, the artist might employ a labeling system of $A, B, C \ldots$ or $1,2,3 \ldots$ to enable viewers to follow the intended sequence of events, similar to the engraving techniques found on carved gourds (mates burilados). See, for instance, the winning entry for the first Ayacucho contest, La gran señal de nuestros recuerdos (El cementerio del horror) (The Great Symbol of Our Memories [The Cemetery of Horror], fig. 1.2), by Manuel Huamán Gutiérrez from Quinua. ${ }^{37}$ Placed in the frame of a cross, scenes "A" and "B" depict the killing and rape first by the military, followed by Shining Path's brutal reprisal. Scene "C" illustrates survivors burying their dead. The last scene, "D," has community members embracing, perhaps a reference to return and repair, or more likely to departure as suggested by the 


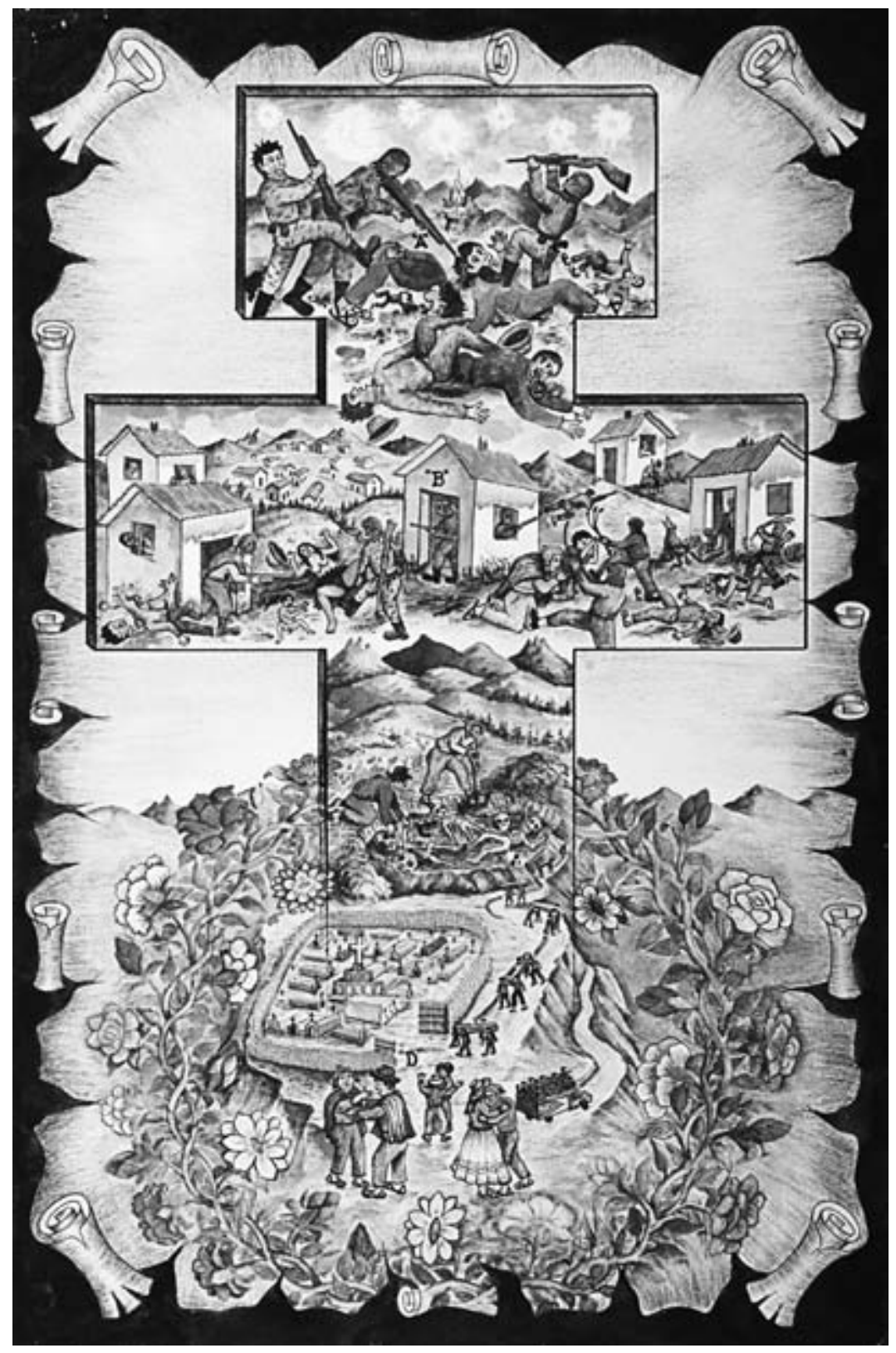

FIGURE 1.2. The Great Symbol of Our Memories (The Cemetery of Horror) (El gran señal de nuestros recuerdos [El cementerio del horror]), by Manuel Huamán Gutiérrez (Quinua). Reprinted with permission from Colectivo Yuyarisun, Rescate por la memoria, 11. 


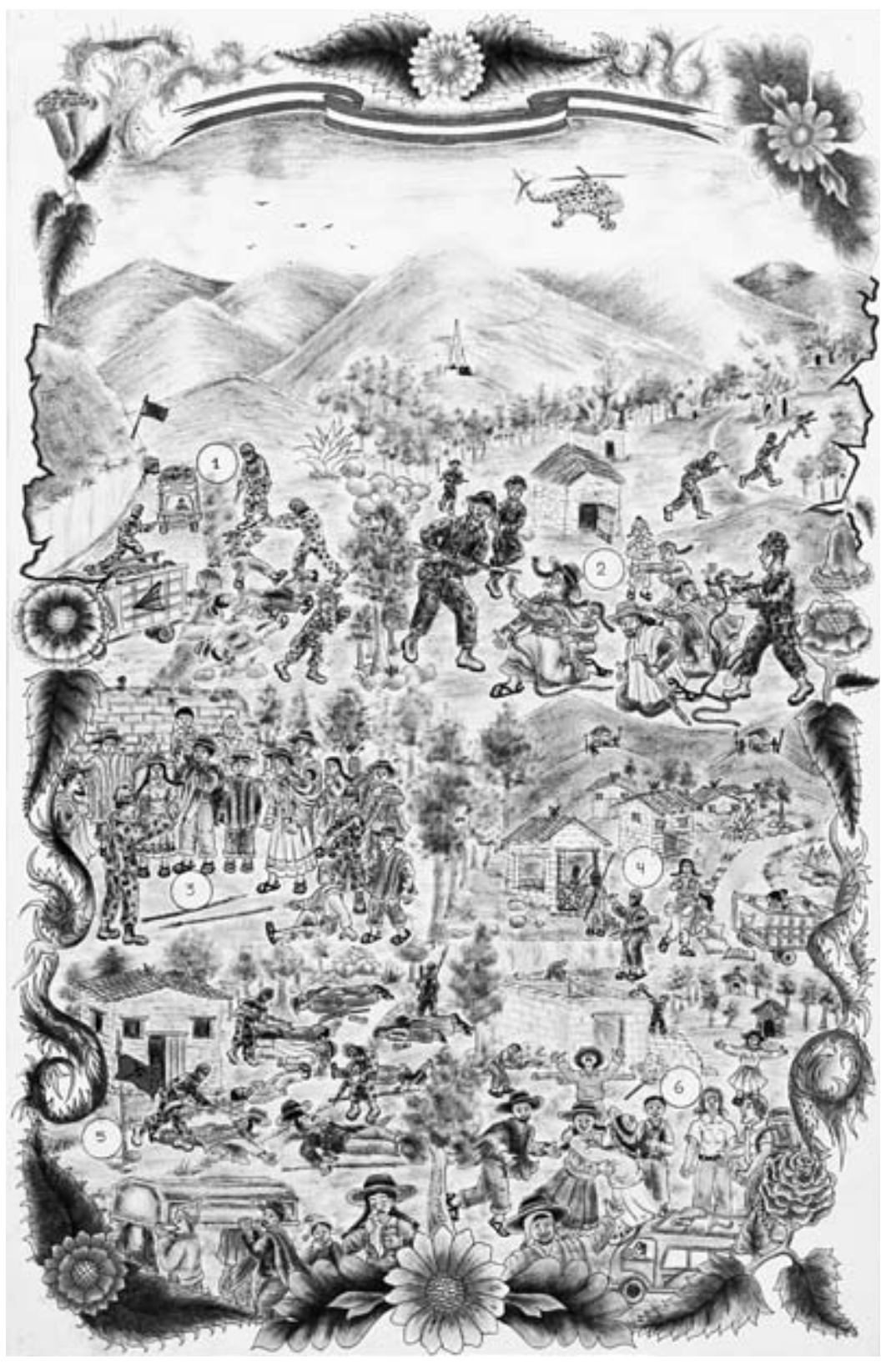

FIGURE 1.3. Reality (La Realidad), by Pablo Huamán Gutiérrez (Quinua). Reprinted with permission from Colectivo Yuyarisun, Rescate por la memoria, 18. 


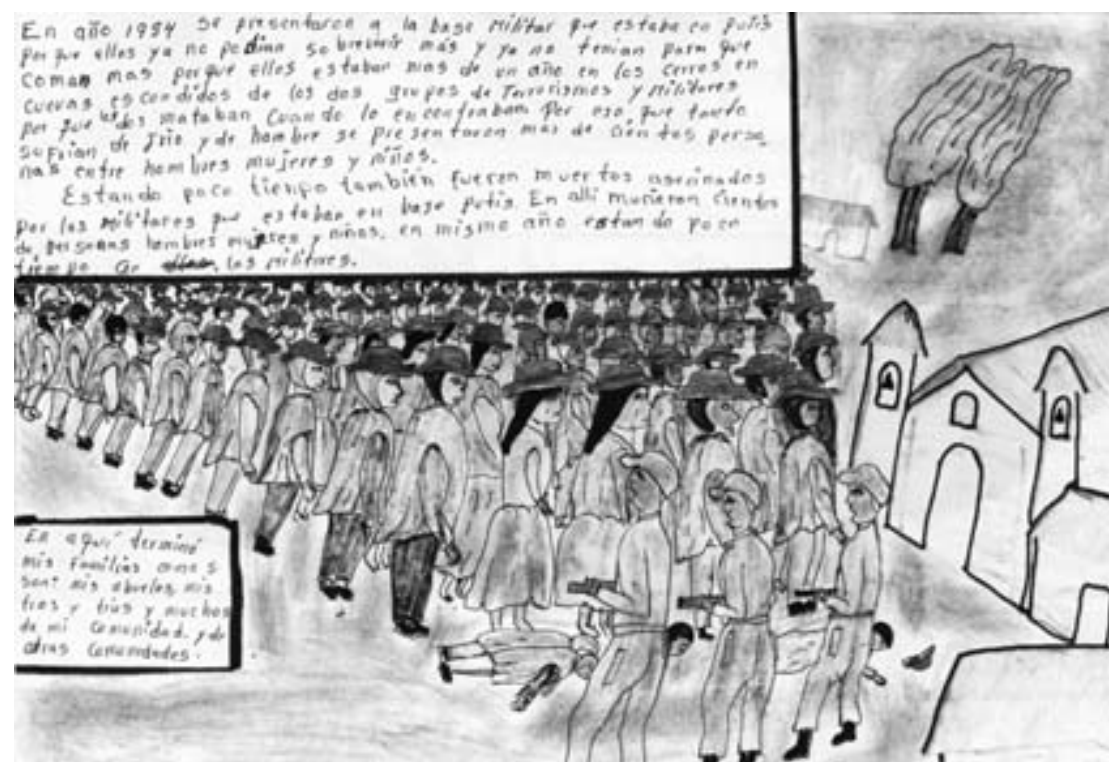

FIGURE 1.4. Last frame in Thus Began the Sad Life (Así comenzó la triste vida), by Gonzalo Fernández Condoray (Viscatampata Orccohuasi, Huanta). Reprinted with permission from Colectivo Yuyarisun, Rescate por la memoria, 91.

descending truck, a depiction of the waves of internal refugees. A similar entry, La Realidad (Reality, fig. 1.3), by Pablo Huamán Gutiérrez, also from Quinua (they are likely related), shows the same events in a numbered format with some differences. ${ }^{38} \mathrm{He}$ adds a scene (" 5 ") of the military returning after Shining Path. In the last segment ("6") the community rebuilds their houses, and community members greet recently returned emigrants. Flowers similar to those found on the doors of retablos adorn the edges of this work.

In the case of the historietas, or comic strips, the framework of serial scenes ensures that readers follow the intended order. In the submission Así comenzó la triste vida (Thus Began the Sad Life, fig. 1.4), Gonzalo Fernández Condoray tells his story chronologically in five frames, using the first person singular. ${ }^{39}$ The sequence recounts his life during the height of the violence from 1982 to 1984 , when his community, Viscatampata Orccohuasi (Huanta), was forced to hide from both Shining Path and the military in caves for more than a year. Eventually driven from the caves by starvation, they sought refuge in a military base in Putis. 
"Here died hundreds of people, men, women, and children, in this same year, after a short time with the military. Here ended my family as is: my grandparents, my uncles and aunts, and much of my community and other communities."

Captions that accompany the pictures read like journal entries. These descriptions might be used to clarify the context surrounding the work, but they also strengthen an artist's claim to veracity. The use of dates in the works further suggests a concern to document and pinpoint the specificity of remembrances. For example, in the painting Sangre que corre (Flowing Blood, fig. 1.5), by Edmundo Soto Vásquez of Concepción, above the scene of three dead men, a lone woman, two soldiers, and smoldering rooftops, the artist has written in pen "In the Plaza of Pirhuabamba on October 9 in the year of 1993, at five in the afternoon, they killed 15 ronderos. Burned houses." ${ }^{40}$ By placing a date, artists assert that specific events occurred at certain times, in certain places, and that despite the passage of time these events are not forgotten but are images engraved into their memories. Such claims of veracity might be in response to the potential threat of forgetting, indifference, and skepticism by spectators. And indeed, by incorporating written text, the artists might be expressing an awareness of the primacy given to written texts over visual and oral witnessing, a powerful dynamic of exclusion. Veracity might be easier to establish through written than pictorial narrative.

While the entries themselves are based on individual participants' memories, their perspectives often represent that of the community. In this way, individual and collective memory may fuse. The narrator takes an omniscient position (seldom using the first person or making the artist-witness's presence explicit). The scenes rendered are of the village or a group. Many include the central plaza or church. The perspective is that of a bird's-eye view of the community: in some works, a condor, dove, or vulture may fly in the upper portion. In an entry for the Huancavelica contest, Santos Belito Unocc from Chacapunco placed the sun and a condor in the top center (fig. 1.6)..$^{41}$ In between the bird and a mountain peak he wrote: "Apu Echoccallan de Parco Chacapunco in 1986, September 28." Here, the mountain spirit (Apu) also witnessed what happened on this day to the community at its base.

Some artist-witnesses distance themselves from the events by making animals the protagonists who recount events. In two historietas from the 2003 Ayacucho contest, birds and dogs narrate the comic strip. In the first part of the historieta, 


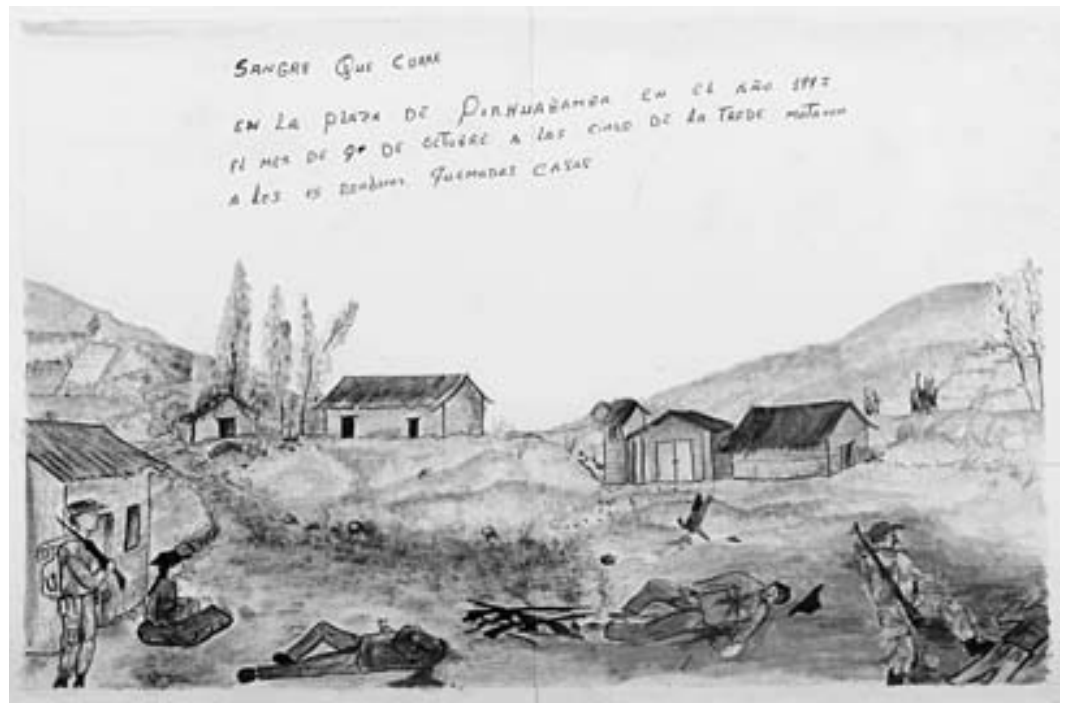

FIGURE 1.5. Flowing Blood (Sangre que corre), by Edmundo Soto Vásquez (Concepción, Vilcashuamán). Reprinted with permission from Colectivo Yuyarisun, Rescate por la memoria, 29.

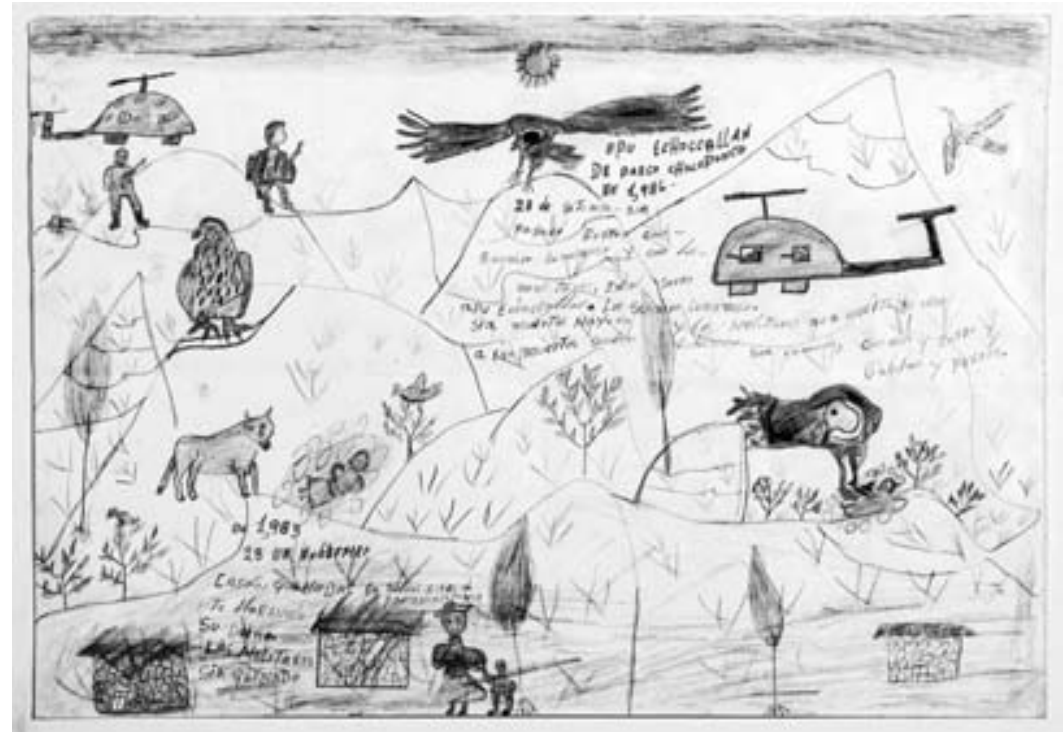

Figure 1.6. History of 1986, Shining Path Massacre (Historia de 1986, Matanza del S.L.), by Santos Belito Unocc (Chacapunco). Reprinted with permission from Asociación SER, Rescate por la memoria, Huancavelica, 24. 

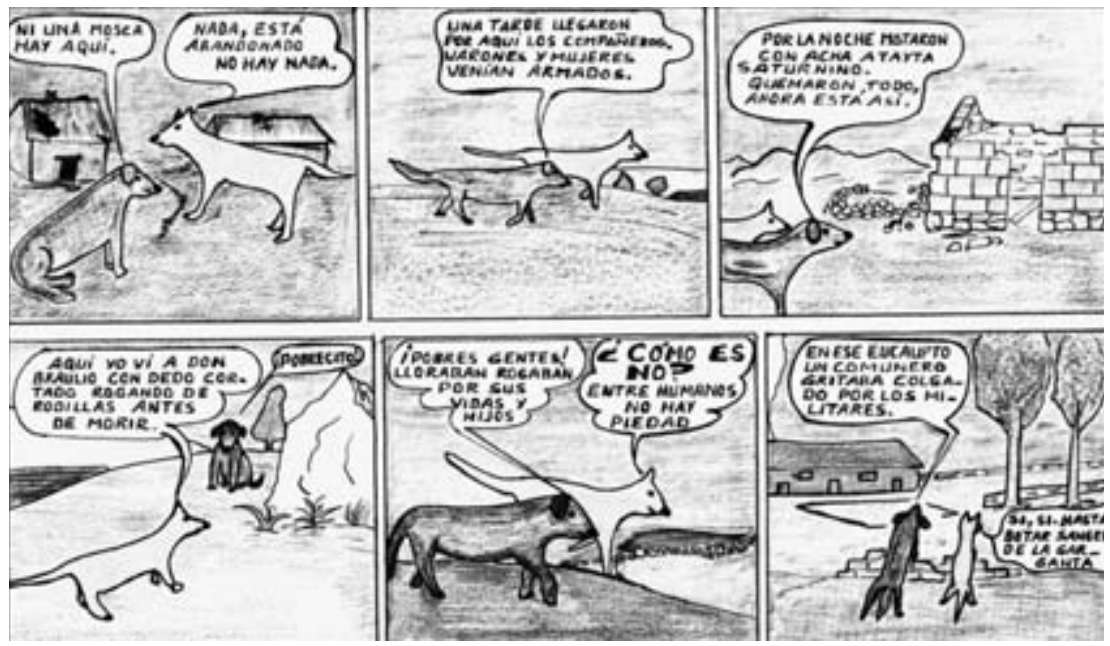

FIGURE 1.7. Excerpt from A Return to the Past and between the Struggle (Una vuelta por el pasado y entre el esfuerzo), by Luis Ayala Mamani (Chiara, Huamanga). Reprinted with permission from Colectivo Yuyarisun, Rescate por la memoria, 63.

Una vuelta por el pasado y entre el esfuerzo (A Return to the Past and Between the Struggle, fig. 1.7), two dogs, calling each other by the racialized terms "Zambo" and "Cholo," converse about what happened in the now abandoned community. ${ }^{42}$ They name specific individuals who were killed and where their bodies can be found. They pose questions and provide answers, for example: "How can this be? Between human beings there is no pity." Such narrative tricks allow the artist to make general comments and observations without taking an authorial stance as a firstperson witness. The protagonism of dogs is further interesting, since witnesses to the CVR referred to the way they were "treated like dogs" by the military and Shining Path and how cadavers were left to be devoured by dogs. In several other Rescate por la Memoria contest entries, Shining Path and the military refer to their victims in racialized and dehumanized terms as perros (dogs). ${ }^{43}$ In this particular historieta, the tables are turned as dogs, using humans' pejorative names to address each other, question the perpetrators' humanity.

Another noticeable aspect of these artworks is their specific placements of acts of violence. Many map past violence by placing spatial markers that indicate where events occurred. The use of maps to narrate the violence might be a direct 


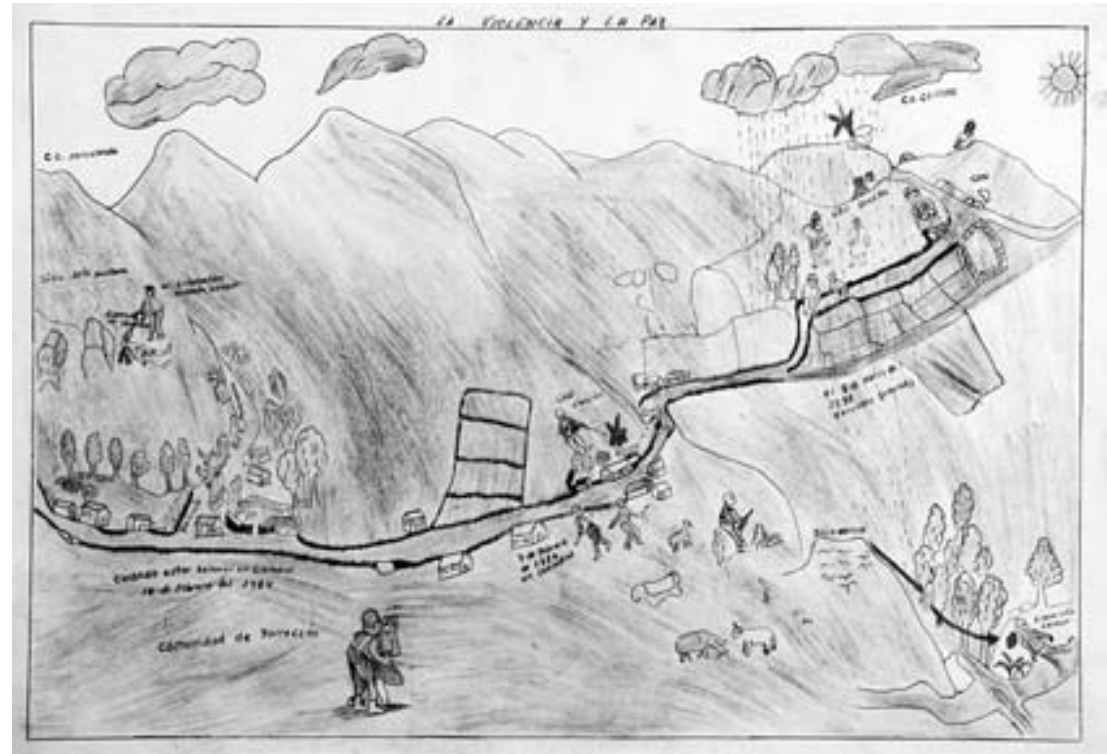

FIGURE 1.8. The Violence and the Peace (La violencia y la paz), by Leonidas Huamán Lolay (Chaynabamba). Reprinted with permission from Asociación SER, Rescate por la memoria, Huancavelica, 29.

legacy of earlier exercises with human rights groups, such as earlier agricultural and electoral maps, and the workshops in preparation for the truth commission's arrival. The mapping techniques in the later artworks entered in the Rescate por la Memoria contests hints that participants in earlier NGO workshops might have understood the mapping exercise as not just one of conveying information but also as an artistic endeavor. Similarly, artist-witnesses may have understood the making of works for the Rescate por la Memoria contests as artistic endeavors that included the conveying of information.

The Rescate por la Memoria contest maps situate the violence with physical markers of roads, buildings, central plazas, homes, animal corrals, mountains, valleys, and rivers. Through these markers, artist-witnesses could indicate several temporal events on the same plane. Thus, a depiction of Shining Path and the military in the same painting may not necessarily mean a direct confrontation between the two. In his painting La violencia y la paz (The Violence and the Peace, fig. 1.8), Leonidas Huamán Lolay depicted three different days: February 
15, 1984 (during Carnival), February 7, 1986, and April 9, 1990 (during the general elections). ${ }^{44}$ In some of the works that map memories of past violence, the aesthetic appears secondary to what seems like an urgent need to document. For instance, Julio Gómez Aguilar of Churcampa has crudely drawn roads, trees, and buildings in his entry, Maraypata (Flat Basket). ${ }^{45}$ He has written down the locations of where community members died: "Aquí murieron Gregorio Quispe y [illegible]" ("Here died Gregorio Quispe [and someone else]").

In fact, surprisingly few of the submissions in the original Ayacucho (2003) and in the Huancavelica (2004) contests seem to take a purely symbolic or abstract approach to their subject. This was not the case for the urban Ayacucho contest of 2004, when many entrants give the impression of striving for "Art." Perhaps the most marked difference between the contests in Ayacucho (2003) and Huancavelica (2004) on the one hand and the contest in urban Ayacucho (2004) on the other is that the dibujos pintados have lost some of their testimonial character in exchange for a more polished look. While most of the former entries displayed specific scenes of violence, around 75 percent of those submitted for the 2004 contest in urban Ayacucho present general paintings of suffering and violence without indicating specific events. One dibujo pintado is reminiscent of Jackson Pollock, with spattered paint. ${ }^{46}$ A more polished look is also visible in the historietas category of the 2004 Ayacucho contest. With superhero-like figures and sound effects of "BLAM!" "воOM!" and "RATATATA," these narrative sequences are closer to Marvel comic books in style than the historietas entries of the 2003 Ayacucho and 2004 Huancavelica departmental contests, though their content recounts similar tragedies.

The shift in artistic style of the 2004 urban Ayacucho from the departmental contests might be because the entrants interpreted the 2004 contest as more about aesthetic than testimonial expression. They might also have been responding to what they thought might have better chances of winning. ${ }^{47}$ Or established and budding artists might have decided to use this new art forum as a means to draw attention to their work. While we do not have information on participants' professions in 2003, the departmental Huancavelica contest and the urban Ayacucho contests of 2004 demonstrate important differences: in Huancavelica, none of the participants were identified as "artists" or "artisans"; in urban Ayacucho, these two categories account for 11 of the 243 contributors, 
in addition to some who described themselves as graphic designers. In both cases, students were the largest category (33 of 112 in Huancavelica, or 29 percent, and 123 of 243 in urban Ayacucho, or 51 percent). No one identified as an "agriculturalist" submitted a work in the urban Ayacucho contest, whereas 22 percent of Huancavelica's 2004 entrants labored the land. ${ }^{48}$

\section{Generational, Gendered, and Racialized Memories}

In summarizing the internal armed conflict, the former truth commissioner Carlos Iván Degregori described the victims as "poor, rural, indigenous, and young." 49 The same description could be used to describe the entrants of the Rescate por la Memoria contests. The majority of participants in the contests were between the ages of eighteen and thirty, from poor, rural highlands, which are considered largely "indigenous/peasant" regions. While the strong presence of youth in the Rescate por la Memoria contests may reflect postwar demographics and may indicate the target audience of the organizers, it also suggests who would be attracted to taking part in such a contest: students. As one of the judges, the anthropologist José Coronel, noted, the Rescate por la Memoria contest allowed "these young Andeans to bolster their expressive capacity." ${ }^{50}$ In Huancavelica, of the ninety-seven participants whose age is known, nearly half (48 percent) were under thirty or younger. ${ }^{51}$ In the urban Ayacucho contest (2004), of the 219 entrants whose age was indicated, 134 (61 percent) were under thirty. ${ }^{52}$ In both cases, most of the women who submitted works were younger than twenty-five. That is, during the "militarization of the conflict" (the phrase used by the CVR to indicate the greater presence of the military in the region), from 1983 to 1986, many Rescate por la Memoria contest contributors were between the ages of four and twelve. They had been children during the three worst peaks of deaths and forced disappearances: in 1984, 1989, and 1990. ${ }^{53}$

Thus, these contest entries represent memories of a generational experience. They are testimonial accounts by individuals who at the time were children or young adults who witnessed the violence committed by the armed forces and Shining Path in their communities: torture, rape, death, disappearance, hunger, massacres, executions, clandestine burials, and forced migration. For instance, one participant, Vicente Unocc Sedano, called his work showing different violent events Cuando era niño (When I Was a Child). In a separate description attached to 
the work, he noted his age when the depicted events took place: he was nine or ten years old when three women in his community were killed and three others harmed (in 1982); he was eleven years old when the army "mistreated" professors, students and community members and "men, women and children [were] tortured in 1983"; fourteen when there was a battle between Shining Path and the military; and fifteen when "El Señor Satos Lara was assassinated in the mountains by three unknown Senderos who placed on him a sign saying 'informer." As a consequence of these many years of violence "we are all traumatized." 54

Perhaps because so many of the works in the Rescate por la Memoria contests are from individuals who were children at the time of the violence, many of the submissions reflect a strong sense of nostalgia for childhood and the past before the war. ${ }^{55}$ For instance, in the historieta titled Mi Familia (My Family, fig. 1.9), Félix Chocce Belito describes in seven frames the happiness of his family in the community of Parco Alto, where they had enough to eat and a cow to milk. Suddenly, in the eighth frame, the military appears (as though from nowhere), and his father begs them to take pity on his family, for whom he provides. In the ninth frame is a single grave. ${ }^{56}$ This romanticization of the past might reflect a child's perspective of childhood in peacetime, despite hardship. Chocce Belito was twenty-nine at the time of the contest and would have been around nine in 1984. However, this nostalgic return to the past before the violence erases the root causes behind the initial success of Shining Path and the endemic poverty these regions suffered before the internal war.

One of the heart-wrenching results of the conflict was the creation of orphans. According to the CVR, widows and orphans were the Peruvians for whom the violence had the most devastating consequences, not only in the loss of family, belongings, and resources but also in lasting psychological and social harm. ${ }^{57}$ The former coordinator of the Mental Health Unit of the CVR, Viviana Valz-Gen, describes the sudden transformation by political violence of a person into an orphan as a "fracture in the life process" that "results in rage, rupture of world order, the loss of sense in the most basic of things." 58 This experience of becoming an orphan is attested to in the works of the Rescate por la Memoria contests. The participant Rosario Milagros Laurente Chahuayo entered both a drawing and a photograph (the only one for the Huancavelica contest). Her black-andwhite charcoal drawing, Huellas en el Alma (Traces in the Soul, fig. 1.10), shows a 


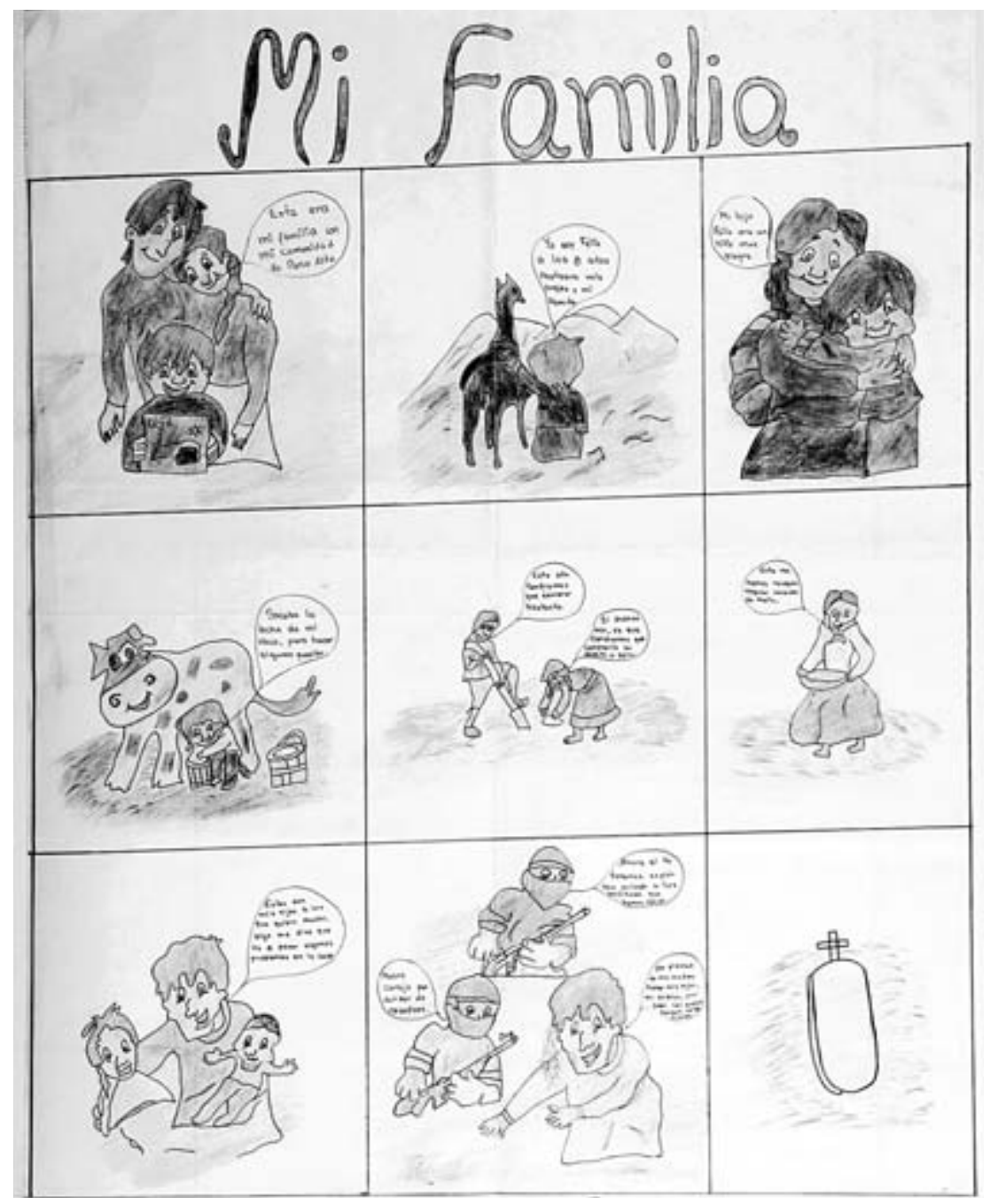

Figure 1.9. My Family (Mi familia), by Félix Chocce Belito (Parco Alto). Reprinted with permission from Asociación SER, Rescate por la memoria, Huancavelica, 82. 


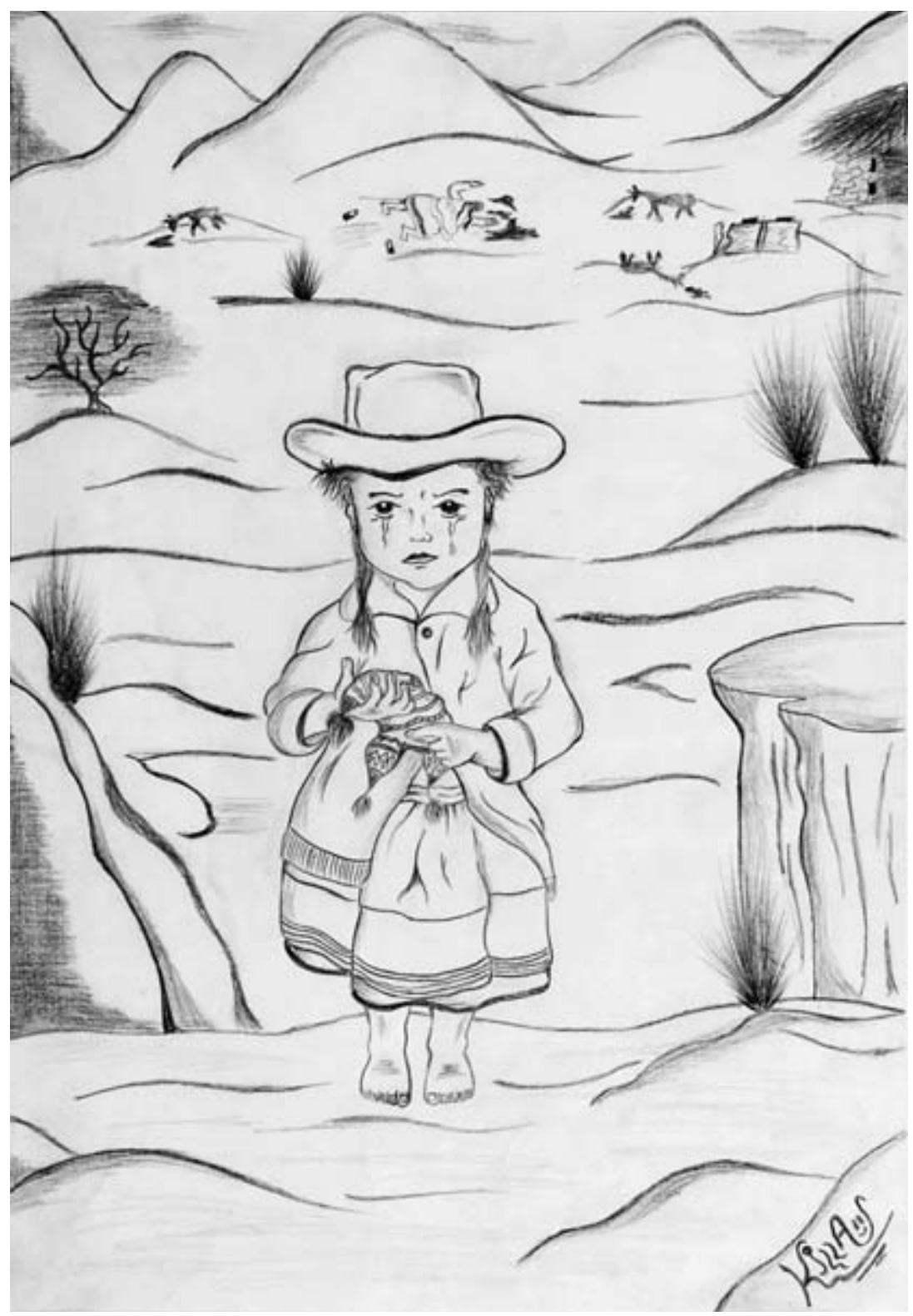

FIGURE 1.10. Traces in the Soul (Huellas en el alma), by Rosario Milagros Laurente Chahuayo (Huancavelica). Reprinted with permission from Asociación SER, Rescate por la memoria, Huancavelica, 15. 
young girl weeping. ${ }^{59}$ The hat of a loved one rests in her hands. She included an explanatory description: "in the image [we] see a girl from Huancavelica with a hat remembering the pain and affliction of an unexplainable violence. [We see the] face of pain and loss of innocent people. In the pain there is no difference between day or night." 60 The participant offers two versions of the same drawing, the one shown here with charcoal on white paper, and another with white pencil on black paper, to emphasize presumably the blurring of time and the transposability of day and night. ${ }^{61}$

Youths had a unique experience in the internal conflict. Shining Path recruited young people from communities and, if no volunteers came forward, would intimidate them into joining. They were also subject to targeting by the military who suspected them of being Senderistas or at least sympathetic to Shining Path. Official suspicion was cast especially on university students. ${ }^{62}$ Students were rounded up and carted off to prison just for attending class or having suspicious reading materials. ${ }^{63}$ Some never returned. ${ }^{64}$ For instance, an undergraduate student in the historieta titled Un día cualquiera de 1990 (Any Day in 1990) by Paul Silvera Cuki of Huamanga asks where his classmates have gone. ${ }^{65}$ His neighbors tell him that his classmates were seized for being terrucos (terrorists). The protagonist asks himself how this could be when they are such good guys, "pero si son buena gente."

The entries also show gendered differences in experiences of the armed conflict - one of the truths of the violence on which the CVR and art converge. Men and women were affected differently by the internal war: over 75 percent of the victims were men over age fifteen (most between the ages of twenty and forty-nine) and were local leaders targeted by Shining Path, or were killed or disappeared by state forces; most of the women who died were the victims of indiscriminate violence and massacres leveled against whole communities. Because of their gender, women were subjected to rape and forced domestic duties (such as cooking and tending to injured members of the armed opposition and the military). ${ }^{66}$ Sexual violence was underreported to the CVR, and only 538 rape cases were registered. Of these, all but eleven were committed against women, and 83 percent were attributed to the armed forces. That it was taboo to speak of sexual violence was made explicit in several of the entries to the Rescate por 
la Memoria contest. ${ }^{67}$ But the Rescate por la Memoria contest submissions also demonstrate that women, like men, played many roles beyond that of victim. Some women chose Shining Path membership, and some organized their communities against Shining Path and military incursions. They searched for their disappeared relatives, put their dead to rest when possible, and cared for their surviving families. ${ }^{68}$

Gendered differences are evident in the choice of contest categories. Interestingly, while women only made up a quarter of the entrants in the original Rescate por la Memoria contest in the department of Ayacucho (2003), they accounted for nearly half of the entries in the song category, and many also submitted poetry, perhaps reflecting the strong oral and lyrical tradition of the region. ${ }^{69}$ The following year, poetry accounted for more than a third of all of women's entries in urban Ayacucho, where women made up a fifth of the participants. In Huancavelica, poetry made up nearly a third of the entries by women, who represented a quarter of the participants. ${ }^{70}$ In all three contests, men disproportionately outnumbered women in the "narration" category.

In addition to these gendered experiences and approaches to recounting the internal war, racial and ethnic dimensions should also be taken into consideration. The racialized aspect of the war is made clear not only in the violence committed against women, who were almost exclusively Quechua-speaking campesinas, ${ }^{71}$ and the non-Spanish speaking victims in general who accounted for three-quarters of the dead and disappeared, but also in the contrast depicted between the coastal-mestizo armed forces and highland residents. ${ }^{72}$ The Rescate por la Memoria contest images illustrate a gulf of power and of foreignness separating perpetrators and victims. The untitled drawing by Fortunata Yance Flores (fig. 1.11) shows a size difference between the sinchis (a special division of the police forces) and the local residents. While there were at most 120 sinchis in Ayacucho, their ability to get places quickly by helicopter made them seem more numerous. And indeed, they just seemed bigger, an exaggeration noted by the CVR "because for the most part the sinchis were from the coast [costeños], for them to go to Ayacucho would mean a meeting with an 'other'-Quechuaspeaking Andean - with a different cultural trajectory. In the same way, the local population saw these police members as foreigners. In [one testimonial] description, they say [of the sinchis] that 'they were tall, white: they seemed like 


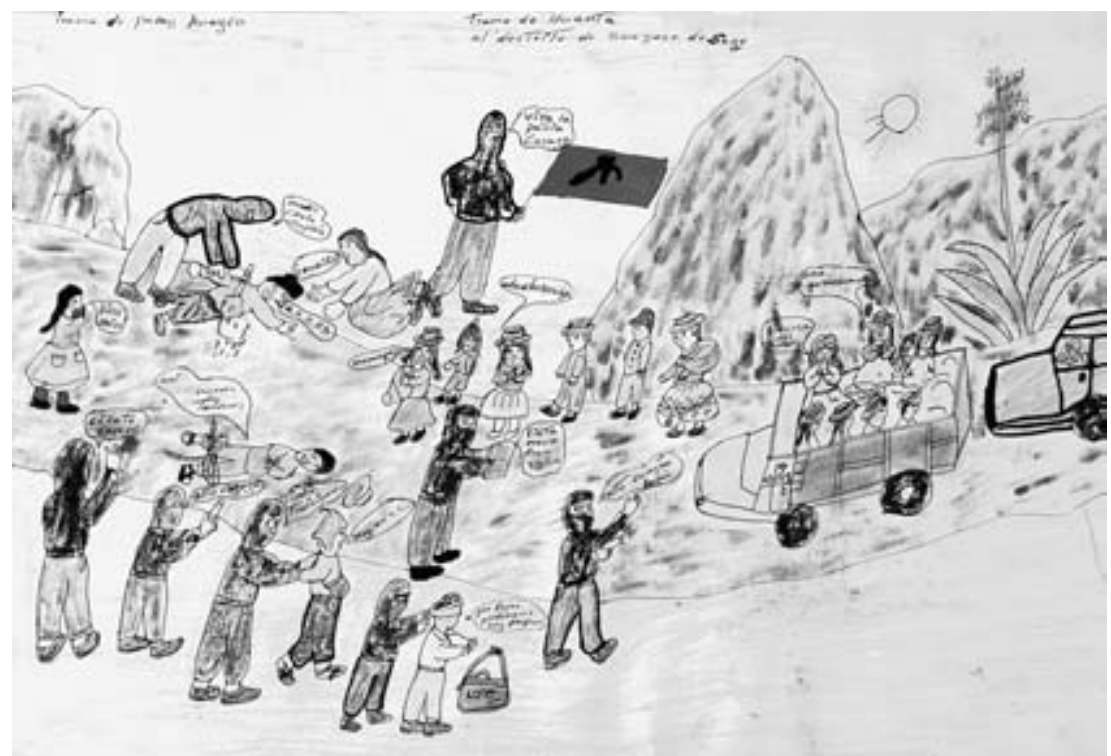

FIGURE 1.11. Untitled, by Fortunata Yance Flores (Santillana, Huanta). Reprinted with permission from Colectivo Yuyarisun, Rescate por la memoria, 38.

Americans and were in camouflage uniforms. They called them the sinchis."'73 Language similarly marked an ethnic frontier between those from the coast and those of the highland: in the drawing by Fortunata Yance Flores the soldiers speak in Spanish and the campesinos in Quechua, reinforcing the perception of the cultural and physical distance of the "other."74

\section{Dissonant Memories: Local Depictions versus the Truth Commission}

Certain visualized memories recur throughout the Rescate por la Memoria contest works, providing a pool of common referents. Many works show animals, birds, religious symbols, skulls, and bones. These common referents mostly testify to human rights violations, yet they do not harmonize fully with the CVR's narrative, despite the commission's focus on victims and enormous compilation of testimonies.

The artworks presented as part of the Rescate por la Memoria contests illustrate principally two agents of violence: the armed forces and Shining Path. Though some works show communities caught between two sides, such as the 
work entitled Entre dos fuegos (Crossfire), for the most part these works depict alone either the state forces or Shining Path. Yet participants did not portray them in equal measure. More artworks had as their subjects severe abuses committed by the armed forces than by Shining Path. ${ }^{75}$ Of the forty-four drawings and paintings in the 2003 Ayacucho contest, thirty-two depict massacres, torture, battles, or other human rights violations. Of these, seventeen testify to abuses by the armed forces, six to Shining Path violence, eight to both agents, and one to ronderos (local defense groups). ${ }^{76}$ The remaining drawings are general scenes of suffering and community. The emphasis on the human rights abuses committed by state armed actors stands in contrast to the findings of the CVR. The commission attributed 54 percent of cases ending in death or disappearance to Shining Path. The armed forces and police were found responsible for 35.6 percent. ${ }^{77}$

The reason that more Rescate por la Memoria contest entrants chose to depict scenes of violence by state armed forces than by Shining Path is complicated, allowing for many possible interpretations. Abuse by the military, police, and other state actors may have been greater and could have been underestimated by the CVR. The entrants might have seen the NGO contest organizers and judges as agents who could transmit their grievances to the state, and to help seek reparations. Participants might have considered the audience (including fellow community members) as more likely to hold the armed forces accountable for their acts than to try to bring the elusive Shining Path to account. Or perhaps the violence committed by the state seemed a greater injustice than that committed by Shining Path, since the armed forces were supposed to protect citizens rather than harm them, as is suggested in the title Las sombras de la injusticia (The Shadows of the Injustice). ${ }^{78}$

By documenting and denouncing state violence, the contest contributors present a world upside down, where citizens are the victims of state repression. ${ }^{79}$ The brutality of the armed forces made them like Shining Path. Thus, in one dibujo pintado (fig. 1.11), a dark-hooded sinchi, standing on the hill in the center of the frame, holds a red Sendero flag and shouts "Viva la patria, carajo" ("Long live the country, dammit"). Below his is a scene of devastation wreaked upon a defenseless community. ${ }^{80}$ Similarly, the drawing Las dos caras de la moneda 
(The Two Sides of the Coin) divides the canvas into halves, with Shining Path on the left and the armed forces on the right, both committing atrocities. ${ }^{81}$ The many images that equated state violence with that of Shining Path challenge discourses about the armed forces as heroic yet simply tarnished by some bad elements who committed individual excesses. Rather, these works depict the systematic use of killings, repression, sexual violence, and terror by state agents against Peruvian communities.

Another possible explanation as to why more of the entries portray state rather than Shining Path violence lies in the category of "victim"-a category all the more requiring of a clear definition since the subsequent implementation of an advisory committee for reparations in 2007. Participants may have interpreted in a particular way who are "acceptable victims," that is, victims worthy of sympathy (and perhaps recognition and reparations) in national and NGO discourse. In post-Shining Path Peru, there is still little room for a "victim" who might have sympathized with or participated in Shining Path at one point or for the abuses within communities that residents committed against one another as part of the escalating violence. ${ }^{82}$ Thus, communities may have made decisions internally not to openly bring up possible Shining Path connections in their past. Rather, the trope of the comunidada asaltada, a passive community struck by Shining Path or by state agents, is the strongest victim trope, as is portrayed in the entry Entre dos fuegos (Crossfire), ${ }^{83}$ which shows a state helicopter dropping bombs and Senderistas firing up into the sky, while a community sits by. The child who is too young to be attributed partisanship is another trope for the "acceptable victim" as in the drawing Los Inocentes (The Innocents, fig. 1.12) that depicts a blindfolded child clutching a doll, with guns held by a Senderista and state agent aimed at her from opposite sides. ${ }^{84}$

What is perhaps most striking in the contest works is the near absence of the theme of reconciliation. In the original contest in the department of Ayacucho (2003), few works make an explicit overture toward reconciliation. The pencil-and paper-drawing titled Verdad, justicia, reparación y reconciliación (Truth, Justice, Reparation, and Reconciliation) evokes the possibility of reconciliation in its title, yet the drawing itself is obscure as how this might be secured: the image shows a cross, a cactus, a candle, a ghost, and a dove. ${ }^{85}$ One other submission, 


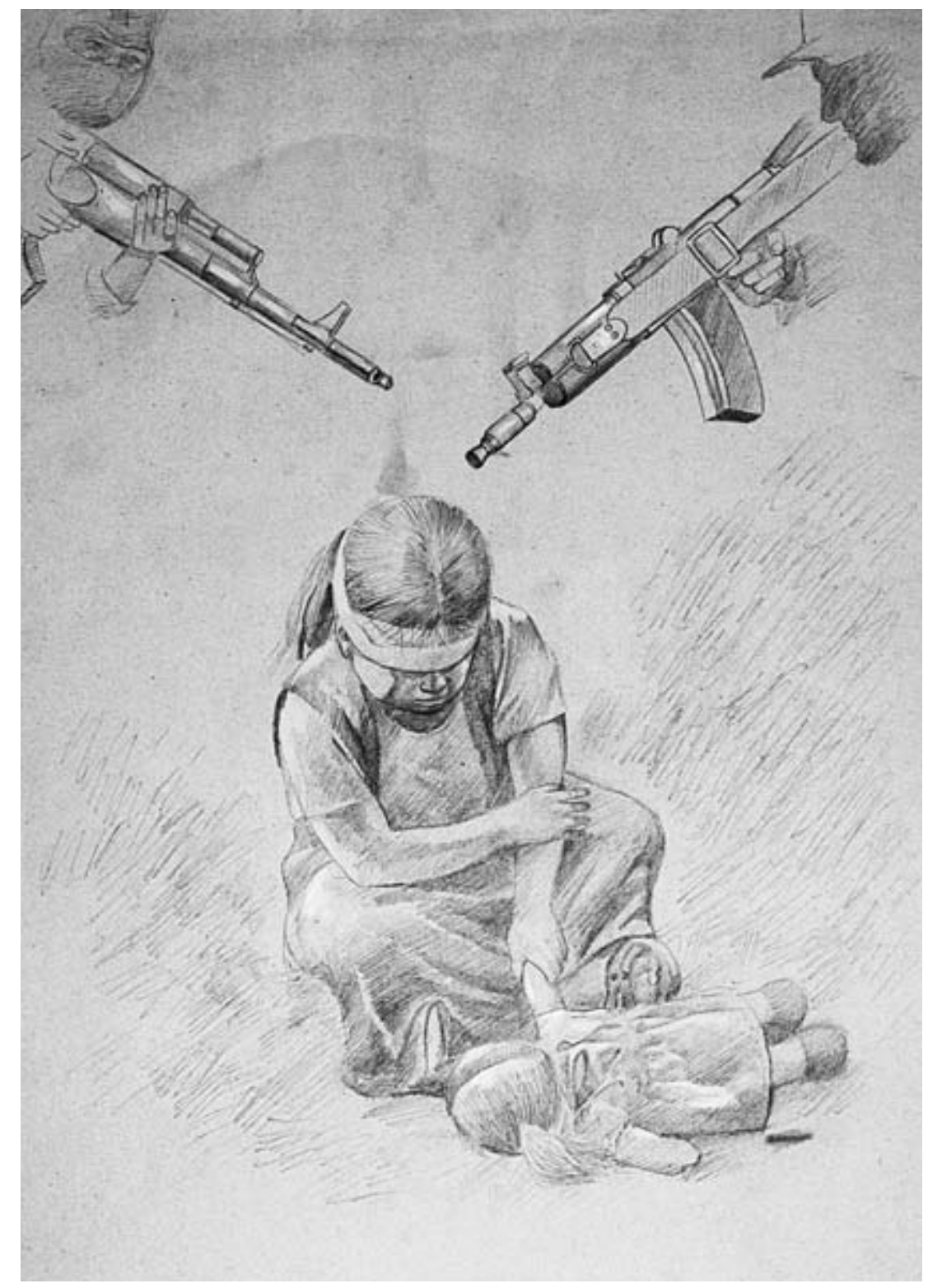

FIGURE 1.12. The Innocents (Los Inocentes), by Henry Riveros Alvizuri (Ayacucho). Reprinted with permission from Asociación SER, Rescate por la memoria, Ayacucho, 68. 
Yuraqurpicha (Little White Dove), simply places a dove of peace in the center. ${ }^{86}$ The contest in Huancavelica that was held a year after the CVR's work ended revealed more pessimism about the chances of reconciliation: not a single work submitted to that contest seems to overtly raise the possibility.

Rather than focusing on reconciliation, many witness-artists chose to address questions of remembrance, continued poverty, and the base of rubble on which a new era must be built. One painting repeats the message of remembering, Recordando para no volver a vivirlo (Remembering So as Not to Live It Again, fig.1.13), a brightly painted image with vivid hues of purple, blue, green, and peach, showing a woman with a young child in her arms and surrounded by her memories of suffering, which stand in stark contrast to those of her daughter, who was born after the war and thus thinks only of full crops and school. ${ }^{87}$ One painting depicts people moving on, not because of having reached a kind of reconciliation with their past or with others, but by growing crops on their dead: Sembrando sobre nuestros muertos (Planting Seeds on Our Dead). ${ }^{88}$ La Realidad (Reality fig. 1.3) depicts in the foreground residents rebuilding their homes and embracing returning community members; this scene is about repair rather than reconciliation. ${ }^{89}$ One entry rejects the possibility of repair: Desgarros irreparables (Irreparable Lacerations) shows a man with tears in his eyes (perhaps a self-portrait), a weeping woman, a coffin, and the initials MRTA (Revolutionary Movement of Túpac Amaru). ${ }^{90}$ The submission Huérfano de Dios y entenado del Diablo (Orphan of God, Stepson of the Devil, fig. 1.14), possibly by a family member, is very similar. ${ }^{91}$ It shows the same weeping woman in the bottom right. But in this painting the artist has included rape, torture, and executions by the armed forces. In the background are the electric towers that provide electricity to Lima, targeted by Shining Path. Graffiti of MRTA and Shining Path are painted on the walls. In the bottom left, sharing the foreground with the weeping woman, is a small malnourished boy with an amputated leg. Over him is draped a torn Peruvian flag with the inscription "Forjemos un Perú de paz sin violencia" ("Let's build a Peru of peace and without violence"), a call for peace but not necessarily reconciliation. 


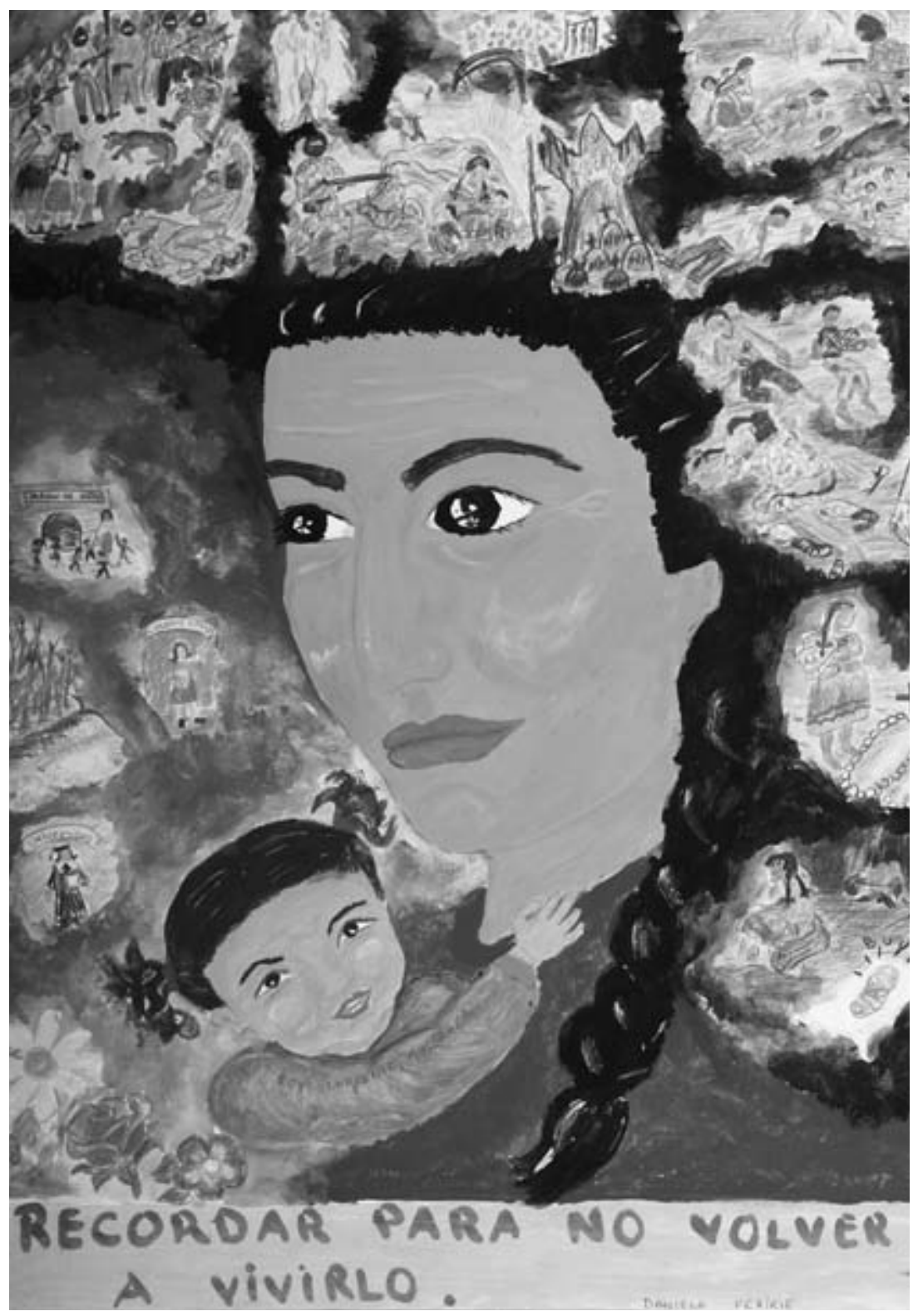

FIGURE 1.13. Remembering So as Not to Live It Again (Recordando para no volver a vivirlo), by Zoraya Zevallos Delgado (Lima). Reprinted with permission from Asociación SER, Rescate por la memoria, Huancavelica, 12. 


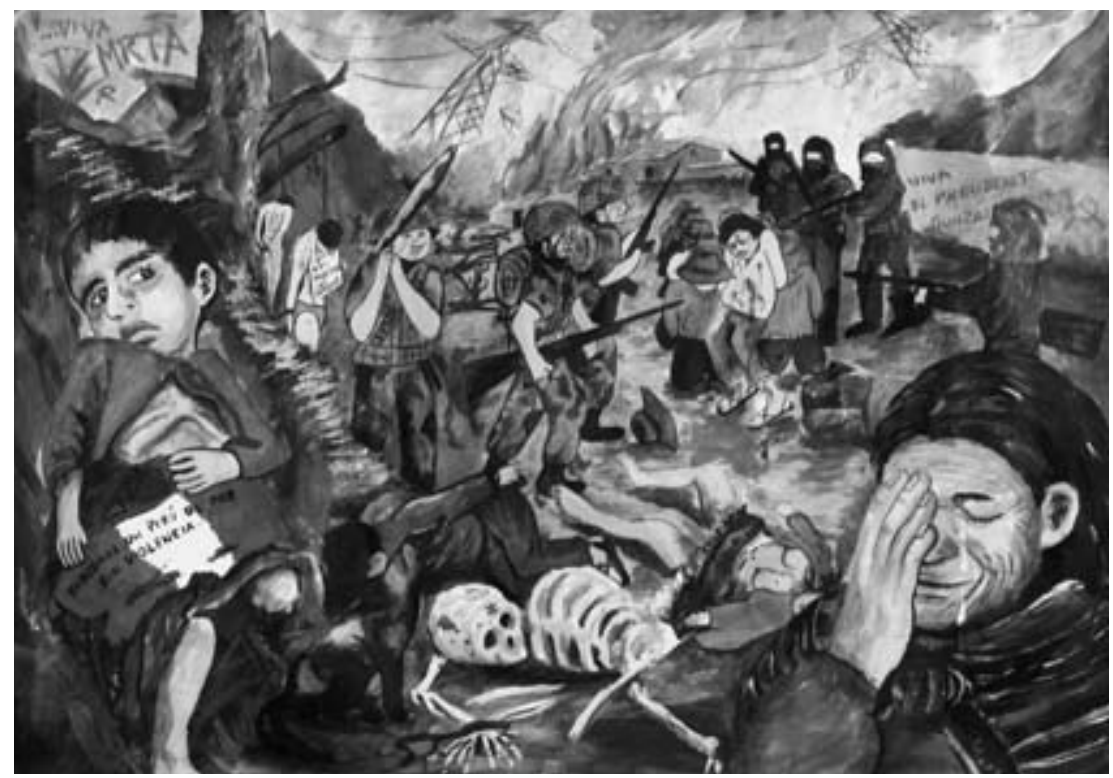

FIGURE 1.14. Orphan of God, Stepson of the Devil (Huérfano de Dios y entenado del diablo), by Edwin Montañéz Ángeles (Huancavelica and Lima). Reprinted with permission from Asociación SER, Rescate por la memoria, Huancavelica, 27.

Conclusion: Rescuing Memories through Testimonial Art for a New Peru

The memories of these contests' participants do not yet fit into a national narrative of the years of violence. While the symbols, scenes, and referents in these works are probably recognizable at the level of the community, they take on the quality of "lore" at the national level, things that bystanders may have heard about but do not necessarily fully believe. ${ }^{92}$ A dramatic example of this is the massacre in December 1984 of 123 men, women, and children from nearby villages who took refuge in the military base at Putis, only to be murdered by their hosts shortly after their arrival. Though depicted in the Rescate por la Memoria contest (for instance, in the historieta titled Así comenzó la triste vida [Thus Began the Sad Life], fig. 1.4) and attested to at length in the CVR's Final Report, this massacre did not gain national recognition until the exhumation of mass graves in May and June 2008. Now Putis has become an emblematic case of the internal 
war, "showing a reality beyond that which one imagined." 93 These artworks thus do not reveal secrets, a characteristic sometimes attributed to testimonio. ${ }^{94}$ Rather, these are known experiences. Nor do these artworks recover lost memories; instead, they are rescuing experiences that are at risk of marginalization in national discourses. Thus these artworks indicate their intended audience: the artist-witnesses are drawing and painting for the nation, in particular for those who did not experience the violence firsthand. They want other Peruvians to know about the many hamlets like Putis, the former torture centers such as Cabitos, and the mass graves scattering the countryside. These artists denounce human rights abuses and injustices, and they demand recognition and alleviation of ongoing hardship. Their artistic responses to atrocity explore the possibilities of empathy, provocation, and disturbance that unsettle extant hegemonic accounts.

By way of aesthetic visual representations, participants have given their testimony and presented their versions of truths to the viewer. Thus, these artistwitnesses seem to wish to enter into the national debate over the war years. However, it is questionable whether these artworks and the memories they represent have contributed to a sustained national discourse. In part, the marginal status they continue to have as "folk art" (or popular) reflects the lack in Peru of an inclusive narrative of the internal war years. And even though these depicted memories present images of truth that complement other historical truths in circulation about the years of violence, like those published in the CVR's Final Report and brought to surface with the exhumation of mass graves, these artist-witnesses' memories and those of other individuals and communities affected by the violence continue to be pushed to the edges of public discussion, only to be brought up by those with power when politically convenient. ${ }^{95}$ It is not that these memories are forgotten. Rather, they face national indifference. In the postwar political climate, successive governments and elites have largely ignored the internal war or attempted to rewrite the narrative as one of a national tragedy during which the armed forces defended the nation. The dominating discourse of this heroic narrative renders individual and collective memories that run against it loose, scattered, and without large-scale resonance.

Ultimately, these artist-participants challenge this indifference, rewriting, and forgetting. They acknowledge the humanity of the artists and their com- 
munities, and they denounce the utter wrongness of the violence that was committed. Acting as a bridge between the past and the present, these artworks encourage the hope that one day their memories will contribute to the creation of an inclusive nation, where such atrocity could not happen again. In one artist's optimistic drawing of smiling people gathering around a possible country called, "A New Peru," figures tell the viewer about how good life could be: "Enough with hatred, let's unite our efforts to build a promising country for all Peruvians!" This would be a country "where everyone is treated equally." "We all want a better life where no one of any class is marginalized." "Yes! Where everyone contributes and we all get ahead!"96

\section{Notes}

Many thanks to Carlos Aguirre, Ricardo Caro, Raúl Hernández, Nelly Plaza, Ponciano del Pino, Javier Torres, and Sofía Vera, among others, for assisting with this chapter. The Asociación Servicios Educativos Rurales (SER) has generously granted permission to reproduce the images presented in this chapter. The Social Sciences Research Council of Canada, the Funds de Recherche du Québec-Societé et Culture, and the Canada Chairs Research program helped fund this research. An earlier version of this chapter was published as "Images of Truth: Art as a Medium for Recounting Peru's Internal War." Some of these images are available to view at www.histoireal.ca (accessed June 30, 2013).

1. Colectivo Yuyarisun, Rescate por la memoria, 17.

2. Here I am considering only two categories: dibujos pintados and historietas. My exclusion of written entries (narrations, essays, and poetry) is not meant to perpetuate perceptions of highland communities as solely illiterate. The original contest in Ayacucho in 2003 had a "written historietas" but not a "narrative" category, which was offered in the Huancavelica and Ayacucho contests of 2004. All three contests had a category for song, and both Huancavelica and Ayacucho 2004 included a category for photography. The works submitted are reproduced in Colectivo Yuyarisun, Rescate por la memoria; SER, Rescate por la memoria, Ayacucho; and SER, Rescate por la memoria, Huancavelica.

3. Colectivo Yuyarisun was formed in 2002, composed of the Federación Agraria Departamental de Ancash (Departmental Agrarian Federation of Ancash), the Federación Departamental de Clubes de Madres de Ayacucho (Departmental Federation of Mothers' Clubs of Ayacucho), the Centro de Investigación Social de Ayacucho (Social Investigation Center of Ayacucho), the Instituto de Investigación y Promoción del Desarrollo y Paz en Ayacucho (Institute for the Investigation and Promotion of Development and Peace in Ayacucho), and SER. Colectivo Yuyarisun, Rescate por la memoria, 5. The later contests were organized by SER. 
4. SER, Rescate por la memoria, Sacsamarca, and Falconí, Jiménez, and Alfaro, Lluqanamarka. The fourth contest, held in 2004 in Sacsamarca to pay homage to the victims of this region, is discussed in Caro's chapter here.

5. For instance, organizers from governmental antipoverty programs aimed at rural communities such as the National Program for the Management of Watersheds and Soil Conservation (PRONAMACH). Workshops were held to assist highland immigrants in Lima, such as workshops on drawing comics with residents of Lima's Villa El Salvador neighborhood in the 1970s. See Acevedo, Para hacer historietas, 11.

6. Conversation with SER members Ricardo Caro and Javier Torres, November 3, 2005 .

7. Nine Peruvian NGos working on agrarian development launched the first competition in 1984, with the involvement of the national campesino union. Contests were held each year from 1984 to 1990 and then in 1992, 1994, and 1996. Kelleher, "Much More Than a Competition," 112. By 1990, the seventh contest, over fifty groups participated. Bonilla et al., Imágenes y realidad a la conquista de un viejo lenguaje, 35.

8. Bonilla et al., Imágenes y realidad a la conquista de un viejo lenguaje, 29.

9. The San Marcos Cultural Center displayed some of these works from June 23 to August 26, 2005. Museo de Arte de San Marcos, Imágenes de la tierrra.

10. Bonilla et al., Imágenes y realidad a la conquista de un viejo lenguaje, 31. Many entries came with written descriptions, either explanations of the artwork or texts for which the artwork was a further explanation; see Ansión, "Presentación," 22, 23. Karen Lizárraga, among others, situates the tradition of drawing as descended from sixteenth-century drawings of Guaman Poma de Ayala. Lizárraga, "El registro andino." Though variations of Guaman Poma's images circulate widely in Peru, it is a bit of a stretch to consider these artworks direct descendants.

11. Cánepa, "Representación social y pintura campesina,"12-13.

12. During the first six years of the contest, 2,469 people participated. After 1987 , regional contests made a preliminary selection of works to be submitted for the National Peasant Drawing and Painting Contests. For this reason, the actual number of participants and works exceeds this figure. Bonilla et al., Imágenes y realidad a la conquista de un viejo lenguaje, 37. Kelleher, "Much More Than a Competition," 120.

13. Conversation with Nelly Plaza, one of the contest's founding organizers, June 21, 2011.

14. Bonilla et al., Imágenes y realidad a la conquista de un viejo lenguaje, $42 n 3$.

15. According to Nelly Plaza, there were some seven or eight categories of evaluation and prizes were awarded in each category. Conversation, June 21, 2011.

16. Bonilla et al., Imágenes y realidad a la conquista de un viejo lenguaje, 38.

17. Ansión, "Presentación," 21. 
18. Ansión, "Presentación," 23. Pajuelo analyzes some of these images in his essay "Miradas del horror."

19. Reynoso, "El Concurso y los participantes," in SER, Rescate por la memoria, Ayacucho, n.p.

20. On local technologies of social repair, see Pilar Riaño and Erin Baines "Transitional Justice and the Everyday."

21. Guerin and Hallas discuss the nexus between visual studies and trauma studies in their introduction to Guerin and Hallas, The Image and the Witness. Testimonial art, according to LaCapra, is a kind of performative, "traumatized or post-traumatic writing ('writing' in the broad sense that extends to all signification or inscription)." LaCapra's conceptualization of testimonial art includes both the witnessing and the working through of trauma. LaCapra, Writing History, Writing Trauma, 105.

22. Trauma art refers to professional artists who use art as "a vehicle for the interpersonal transmission of an experience," an experience that the artist might not have had firsthand. Bennett, Empathetic Vision, 6-7.

23. For a review of the origins and scholarly debate over testimonial literature, see Mallon, "Editor's Introduction."

24. Maclear, Beclouded Visions, 19on. 7. Brett, Through Our Own Eyes, chap. 4.

25. Indeed, in this way, the artworks seek justice and recognition from an intended audience beyond that of judges and commissioners to include bystanders, like with other mechanisms of trials and truth commissions. Minow, Between Vengeance and Forgiveness, 74-79, 146.

26. Similarly, the organizers of the Rescate por la Memoria contests refer to the entries as "testimonios" by hundreds of people who lived the violence in one form or another. Colectivo Yuyarisun, Rescate por la memoria, 5.

27. Quoted in Maclear, Beclouded Visions, 17.

28. Guerin and Hallas, introduction; Maclear, Beclouded Visions, 23. Bennett considers "trauma-related art" transactive rather than communicative, in that it "touches us, but it does not necessarily communicate the 'secret' of personal experience." Trauma art thus conveys "truths" "because it reaches us through our senses." Bennett, Empathetic Vision, 8-9.

29. Maclear, Beclouded Visions, 21. This unfortunate tendency to view "folk art" as somehow closer to a nonaesthetic reality is similar to the national reception for retablos as described by Ulfe in her chapter here. On the limits of asking testimonial literature to represent authentic subaltern voices, see Beverley, "The Real Thing," and Mallon, "Editor's Introduction."

30. Cánepa makes this same point in regards to earlier National Peasant Drawing and Painting Contest works, "Représentation social y pintura campesina," 12-13. 
31. In the earlier national contests, NGOs encouraged contributors to include letters with their entries: "the letters are decisive as many of them help us [Peruvians not from the region, the contest organizers, and judges] to understand better the images especially for those of us who are not of the same ethnic origins." Bonilla et al., Imágenes y realidad a la conquista de un viejo lenguaje, 162.

32. Conversation with Arianna Cecconi, August 20, 2008. Cecconi, "Dreams, Memory, and War."

33. Pajuelo, "Miradas del horror," 96-97.

34. Cecconi, "Dreams, Memory, and War," 409; Ritter's chapter here.

35. As Cánepa has argued for the pintura campesina of the national contests, if we look just at the figurative representations in these works, we will lose out on the possibility to see the "complex dynamics and cultural, social and political negotiations that are accomplished through visual language." "Representación social y pintura campesina," 13.

36. Vergara states this as one of the key reasons why graphic images of violence, regardless of their disturbing content, should be published. Vergara, "La memoria de la barbarie en imágenes," 18. This sentiment is shared by Kyo Maclear, who writes that art can also draw us, as viewers, "emotionally and intellectually toward the unknown." Maclear, Beclouded Visions, 24.

37. Colectivo Yuyarisun, Rescate por la memoria, 11. This winning entry is also on the cover of Theidon, Entre prójimos.

38. Colectivo Yuyarisun, Rescate por la memoria, 18.

39. Colectivo Yuyarisun, Rescate por la memoria, 89-91.

40. Colectivo Yuyarisun, Rescate por la memoria, 29.

41. SER, Rescate por la memoria, Huancavelica, 24.

42. Colectivo Yuyarisun, Rescate por la memoria, 63-65.

43. For instance, a Senderista shouts out "mueran como perros" (die like dogs) in the entry titled Rescate por la memoria, which depicts a Shining Path massacre, in Colectivo Yuyarisun, Rescate por la memoria, 14. Based on her interviews with survivors, Theidon recounts how community members described the war using dehumanizing terms such as "we lived and died like dogs," in Intimate Enemies, 54.

44. SER, Rescate por la memoria, Huancavelica, 29. Two descriptions accompany this work. One explains what happened on the days of massacres (fiestas carnavales comadres fiesta, and a general election). Another text says "the terrorists [terrucos] gave speeches gathering together the residents [comuneros] of Chaynabamba; in this way [Shining Path] managed to recruit leaders, and they gave them [these new leaders] a book that was like a credential or a guide."

45. SER, Rescate por la memoria, Huancavelica, 45.

46. "Tiempos de sufrimiento y dolor," by Percy Lozano Vivanco. SER, Rescate por la memoria, Ayacucho, 65. 
47. Commentators on the National Peasant Drawing and Painting Contests noted that the previous year's winning entries would influence the following year's submissions. One can see this in the Rescate por la Memoria contests: after the first prize went to a stylized cross (fig. 1.2 here), the following year in Ayacucho and Huancavelica several contestants offered similarly adorned crosses.

48. SER, Rescate por la memoria, Huancavelica, n.p.; Rescate por la memoria, Ayacucho, n.p. Colectivo Yuyarisun, Rescate por la memoria, does not provide the ages or professions of participants.

49. Degregori, "Heridas abiertas, derechos esquivos," 81.

50. Coronel, "Présentación," in Colectivo Yuyarisun, Rescate por la memoria, 5.

51. That is, forty-seven participants were under thirty years old, and of these, twenty-five were under twenty-five years old. SER, Rescate por la memoria, Huancavelica, n.p.

52. Of these 134 participants, ninety-one were younger than twenty-five years old. SER, Rescate por la memoria, Ayacucho, n.p.

53. CVR, Ayacucho, informe final 1980-2000, vol. 1, 10.

54. SER, Rescate por la memoria, Huancavelica, 23.

55. Of course, any age group can experience nostalgia. How nostalgia plays out in post-conflict Latin America is a field for further research and at present seems to mainly be the concern of academics working on post-Communist Europe.

56. SER, Rescate por la memoria, Huancavelica, 82-83.

57. Larrabure, Ciertos vacíos, 15.

58. Viviana Valz-Gen in Larrabure, Ciertos vacíos, 77.

59. SER, Rescate por la memoria, Huancavelica, 15.

6o. A similar caption accompanied her photographic entry: "the pain without consolation of a young indigenous girl from Huancavelica. She holds a hat in her hands, that on taking into her hands she remembers her loved ones. The cries of sorrow [llanta] overwhelm her and the idea of remaining alone is her only companion." From yuyarisun. rcp.net.pe/yuyarisun.php?id=catalogo-dibujo2, accessed January 8, 2008.

61. This theme of day as undistinguishable from night is repeated in Jiménez's drawing Como el día era la noche in Chungui, 2005, 170-171, and in Cecconi's conversations with Ayacuchans, "Dreams, Memory, War," 413.

62. The enrollment in universities boomed in the decades preceding the war. The Universidad Nacional San Cristóbal de Huamanga (UNSCH) grew from 228 students in 1959 to over 6,00o by 1980 . On the role of politicization by Shining Path in UNSCH and other universities, see CVR, Informe final, vol. 3, chap. 3.6, and vol. 5, chaps. 2.18-2.21.

63. See, for instance, the historieta Sin título in Colectivo Yuyarisun, Rescate por la memoria, 97-99.

64. One of the human rights violations cases of which Alberto Fujimori was found 
guilty was the disappearance and death of nine students and one professor taken from Lima's La Cantuta University in 1992.

65. Colectivo Yuyarisun, Rescate por la memoria, 96.

66. CVR, Informe final, vol. 8, chap. 2.1.

67. Leiby, "Digging in the Archives," 86-88; Theidon, "Gender in Transition," 417418; CVR, Informe final, vol. 8, 64, 89. Both Leiby and Theidon note that women spoke mostly in the third person when discussing sexual violence. Likewise, some of the most disturbing and graphic images of violence in the first Ayacucho contest went unsigned. Similarly styled drawings suggest the hand of one artist who with less graphic scenes of violence included her name. This decision to not sign some of her works yet to include her name for others reinforces Leiby and Theidon's point about the use of anonymity and the third person.

68. For instance, the entry without a title by Isabel Marquina Sulca depicts in the top left corner a female Senderista relaxing at a table, drinking and conversing with others. Colectivo Yuyarisun, Rescate por la memoria, 36. Escenas de horror (Scenes of Horror) shows a woman walking with her two small children through the violence, by candlelight. Colectivo Yuyarisun, Rescate por la memoria, 20.

69. Colectivo Yuyarisun, Rescate por la memoria, 7.

7O. SER, Rescate por la memoria, Ayacucho, n.p. SER, Rescate por la memoria, Huancavelica, n.p.

71. Bueno-Hansen notes that the CVR had separate sections on gender and race, thus decoupling two key categories of analysis for understanding violence against highland and Amazonian women. Bueno-Hansen, "Engendering Transitional Justice," 69-70.

72. In Peru, geography "racializes" people. The racialized dimensions of the conflict were central to the CVR's conclusions that highlighted discrimination by mestizo elite and governmental agencies against Peruvian highland and Amazonian lowland populations, which was mirrored by Shining Path's treatment of the same groups. On the intricacies of race and ethnic identities in Peru, see de la Cadena, "Discriminatión étnica," and Indigenous Mestizos.

73. CVR, Informe final, vol. 2, 148-149.

74. Colectivo Yuyarisun, Rescate por la memoria, 38. This is also the case in the entries without titles by Crispín Villar Potosino and Magaly Cabrera Pereyra, 42, 43.

75. Ramón Pajuelo similarly notes his surprise at the stronger presence of images showing counterinsurgent forces over Shining Path in the National Peasant Drawing and Painting Contests. Of the thirty-four images he analyzed, the majority fell into his category "Military Incursion." "Miradas del horror," 94.

76. These numbers are based on my interpretations of the actors depicted in the drawings and paintings printed in the contest publications. In the Huancavelica contest, the 
MRTA also appears as a perpetrator of violence whose impact is depicted via images of destroyed electrical towers and graffiti.

77. On the armed actors in the conflict, see CVR, Informe final, vol. 2.

78. By Honorato Suañe Yupanqui, Colectivo Yuyarisun, Rescate por la memoria, 38.

79. The contests in Ayacucho and Huancavelica differ from the Second Homage to the Victims and Heroes in Sacsamarca where participants were asked to depict and reflect specifically on the community's victorious battle against Shining Path in May 1983. Interestingly, as Ricardo Caro notes in his chapter here, even though the police helped to root out Shining Path from Sacsamarca (and one policeman died along with fifteen Sacsamarca community members), the police presence is noticeably underrepresented (if not entirely absent) in the paintings.

8o. Colectivo Yuyarisun, Rescate por la memoria, 38.

81. By Leoncio Laura González (Chincho, Huancavelica). SER, Rescate por la memoria, Huancavelica, 19.

82. Theidon recounts the heart-wrenching story of the "widow in the cave," about a woman who witnessed her neighbors' killing of her husband. Out of fear for herself and her children, she retreated to a cave. Later, when she wished to publicly recount her experience to NGO representatives, male community members quickly silenced her as not knowing what she was talking about. Theidon, Intimate Enemies, 159-164. This story not only highlights who are "permitted victims" within communities but also the gendered dynamics of who is allowed to tell local truths. I thank Steve Stern for sharing this idea of the "permitted victim."

83. By Jorge Luis Vera Lozano (Rancha, Ayacucho). Colectivo Yuyarisun, Rescate por la memoria, 40.

84. SER, Rescate por la memoria, Ayacucho, 68.

85. Colectivo Yuyarisun, Rescate por la memoria, 35.

86. Colectivo Yuyarisun, Rescate por la memoria, 22.

87. SER, Rescate por la memoria, Huancavelica, 12.

88. SER, Rescate por la memoria, Huancavelica, 25. The Yuyarisun website provides a different title for this work, El Agricultor (The Farmer). Félix Chocce Belito also entered a historieta, Mi familia, and a poem, "Mi familia y mi hogar" ("My Family and My Home").

89. Colectivo Yuyarisun, Rescate por la memoria, 18.

90. SER, Rescate por la memoria, Huancavelica, 28. A description accompanies this entry: "it expresses Peru torn apart before the loss of a loved one, killed unjustly in the war by the MRTA, Sendero, and the Army; it also [expresses] the pain and suffering of a mother and a peasant child." From yuyarisun.rcp.net.pe/yuyarisun.php?id=catalogo -dibujo2, accessed January 8, 2008.

91. SER, Rescate por la memoria, Huancavelica, 27. 
92. Stern, Remembering Pinochet's Chile, esp. 130-131.

93. Rojas, "Para comprender Putis y Cabitos," 77.

94. In the case of known secrets coming to light through art, see González, Unveiling Secrets of War in the Peruvian Andes, esp. chap. 6.

95. An example is the renewed interest by the Peruvian government as of 2012 in the massacre of Lucanamarca when it created a "National Day against Terrorism" on April 3, the day of Shining Path's massacre of some sixty-nine Lucanamarca residents in 1983. Yet no such equivalent project for a commemorative day exists for Putis, or other cases of state violence. Indeed, the day that commemorates state armed forces highlights their heroism "The Day of Military Courage," April 22, the day of the successful military rescue of hostages held for nearly four months by the MRTA. On the political uses of the Lucanamarca massacre, see María Eugenia Ulfe and Vera Lucía Ríos, "Lucanamarca querido" (Beloved Lucanamarca), NoticiasSER, March 14, 2012, www.noticiasser.pe, accessed June 30, 2013.

96. Antes ... despúes (Before ... After) by Rubén Gómez Carrasco, Colectivo Yuyarisun, Rescate por la memoria, 101. 
CHAPTER TWO / EDILBERTO JIMÉNEZ QUISPE

CHUNGUI / ETHNOGRAPHIC DRAWINGS OF VIOLENCE

AND TRACES OF MEMORY

Well, my town was just a town, I guess ...

A foreign town inside Peru.

- Primitivo Quispe, testimony given to the

Commision de Verdad y Reconciliación

his chapter consists of twelve drawings and testimonies from Edilberto
Jiménez Quispe's Chungui: Violencia y trazos de memoria. ${ }^{1}$ Jiménez is
an artist and journalist with a degree in anthropology from the Universidad Nacional de San Cristóbal de Huamanga (Ayacucho). As an artist, an ethnographer, and a Quechua-speaking Ayacuchano, he has applied his skills to bear witness to the violence suffered in the remote district of Chungui, in the southern tip of the province of La Mar (department of Ayacucho). The remoteness of the small hamlets that make up Chungui is further emphasized by its nickname, “The Dog's Ear," in reference to its geographical shape, wedged between the rivers Pampas to the west and Apurímac to the east. Chungui was one of the regions hit worst by the internal war; some 17 percent of its population were killed and disappeared in the 1980s to mid-1990s. Flight from the region halved its population. ${ }^{2}$ Chungui is hard to reach; the journey takes some ten hours from the departmental capital of Ayacucho over a series of difficult roads.

Edilberto Jiménez is perhaps best known for his work as a retablista, a family métier he learned at a young age from his father, growing up in the province of Víctor Fajardo to the southwest of Chungui. ${ }^{3}$ In the 1980 os and 1990 s the theme of political violence entered his retablos: Huamanguino (Man from Huamanga), 
Masa (Mass), and Flor de Retama (Retama Flower) are just a few examples of how Jiménez used art to speak of what was happening locally, while at times placing these experiences within a national and global context of exploitation. ${ }^{4}$

Based on his own observations and on testimonies gathered from Chungui residents, Jiménez presents a visually disturbing and powerful account of the violence. He knows the community of Chungui well, having traveled there on many occasions: he first went there in the 1990 os as a member of the Centro de Desarrollo Agropecuario de Ayacucho (an NGo dedicated to agricultural development). Chungui had been one of the beneficiaries of the agrarian reform of 1969 when the state expropriated hacienda landholdings and turned the land over to peasants to cultivate. Moved by the stories he heard of the internal conflict of the 1980 s and seeing the devastation inflicted on the area's people and communities, Jiménez put aside the slow work of retablos and swiftly drew visual representations of the conflict years. The result was a book of originally seventy-two drawings, first published in 2005 and reprinted in 2009 with an additional nineteen drawings, presented in a different sequential order.

Jiménez's work has subsequently inspired others. The story of Chungui is also recounted in Luis Rossell, Alfredo Villar, and Jesús Cossio's graphic novel Rupay. Interspersed in Rupay are five of Jiménez's testimonial drawings, and he appears in the sixth chapter, "Chungui," as a secondary witness speaking from the margins, recounting the stories he himself heard from survivors.

The original publication of Chungui: Violencia y trazos de memoria (2005) starts by providing insight into the nature of this community and culture before the conflict, as a means to place in context the subsequent war years and their continued legacies. ${ }^{5}$ Through the drawings and testimonies, which include the dates and locations of the events described, we learn of local customs such as the musical tradition of llaqta maqta, a dance the town's young people participate in so that they might fall in love and get married. (This image is not shown here.) We also learn of how teachers came to Chungui by the mid-1970s teaching new ideas that mixed the writings of Peruvian philosopher José Mariátegui with Mao Tse-tung that lay at the center of the Shining Path ideology of building a "new society" (fig. 2.1). Next, the drawings give explicit accounts of Sendero violence wreaked on the community, their attempts at defense, and the brutal response by the military, who had arrived by the summer of 1984 . The images 
are searing: Shining Path retaliating against Yerbabuena community for having formed self-defense committees (fig. 2.2). Sendero killed local landowners and authorities (fig. 2.3). Mothers were forced to give up their children to serve Shining Path (fig. 2.5). The cruel and twisted violence of the armed forces in their "antisubversion" campaigns (figs. 2.6, 2.7). The self-defense groups (rondas) who joined the armed forces in their assaults yet also provided refuge (fig. 2.9). Shining Path exacting submission (figs. 2.3, 2.4, 2.5) and forcing community members to hide in the mountains (retiradas), where they endured hunger, exposure, and unsanitary conditions, covered by fleas and lice (fig. 2.8). Chungui residents remember those years in the mountains, 1984-1987, as years when they lived and died like animals. Jiménez also includes the testimonies of former soldiers who remember their experiences with the military differently, one as heroic, the other as brutal (figs. 2.10, 2.11).

Yet, despite these cruel memories and depictions, hope emerges from atrocity's embers. In the first edition of Chungui (2005), the narrative ends with a final picture and text, Concertación (fig. 2.12), which is a call for working together with the Peruvian state to address the Chungui community members' most basic material needs and rights as citizens. In this final image, villagers, noticeably poor in their tattered clothes, march in the hundreds to protest against poverty, illiteracy, the lack of attention to basic health, underdevelopment, neglect, and the state's practice of forgetting. Their present situation stands in stark contrast to their memories of a more peaceful and well-off prewar period. Yet their call remains largely unanswered: according to a 2012 municipal proposal to expand access to potable water in the district of Chungui, 85 percent of the population does not have their basic needs met, 15 percent live in misery, 34 percent of women remain illiterate, 92 percent of the population do not have access to potable water, and 100 percent of the region has no electricity. Chungui is a region of young people, the adult population decimated by the war: 41 percent of the population is under fourteen years old and $3^{1}$ percent between fifteen and thirty-five. ${ }^{6}$

At the methodological level, Jiménez's work employs a unique approach of visual ethnography and participant observation. Unable to capture the gestures of survivors when they demonstrated how people suffered, he put down the tape recorder and took up his pencils. ${ }^{7}$ Jiménez made his drawings in consultation 
78 / edilberto Jiménez QUispe

with local residents and revised them according to their comments. His drawings are a unique collaborative effort between himself as artist/ethnographer/ regional neighbor and Chungui community members. His artistic representations reach a level of empathy and understanding that few others could attain. As Carlos Iván Degregori noted, "Peru and Peruvians have an unresolved debt with Chungui. This book is a form of repayment through ethnography and art."8 Jiménez's work is an attempt to transform the towns of Chungui from foreign towns within Peru's borders into Peruvian towns within the nation's tragedy. 


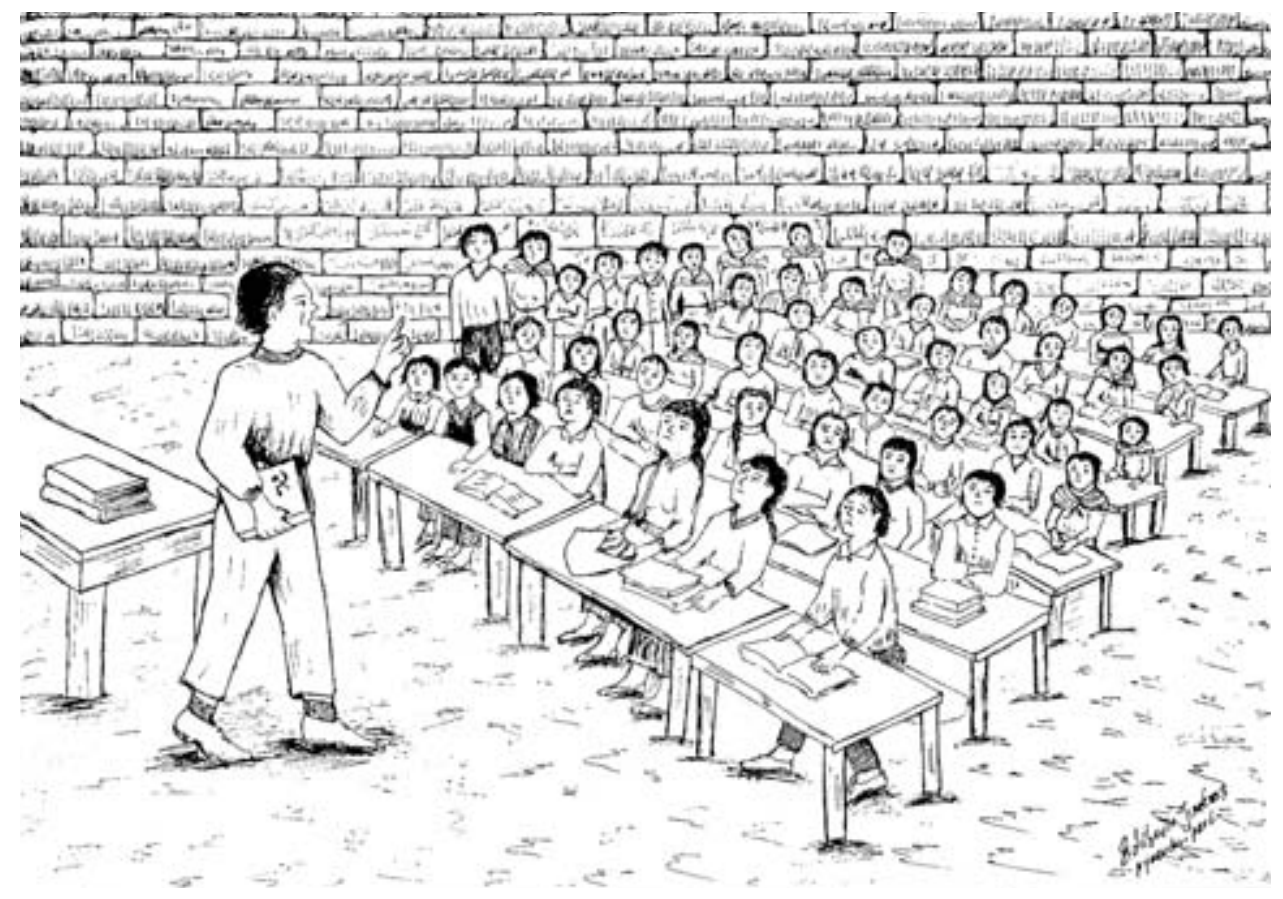

The School Gave Them New Thoughts

(Oronccoy, Chungui, 1982)

I first arrived in Oronccoy in 1967 as a teacher at the state primary school. I came by way of Andahuaylas, crossing the Pampas River, walking over hill after hill; it was so difficult to get here. The comuneros [the community's residents or villagers] still talked of the guerrillas of 1965, they told of how they killed Miguel Carrillo, an hacendado [large landowner] from Chapi, and how afterward the other hacendados fled in fright. They said that the guerrillas were good, but others missed their patrones [bosses], and they still did not want a teacher, saying that that was for the idle. The family of the hacendado of Soccos nearly killed me: they aimed a gun at me to kill me and the campesinos of Oronccoy saved me. My students were seventeen, eighteen, and twenty years old, and they were still in primary school; they wanted to educate themselves, and they cursed the hacendados for not having built schools. 
In 1980, the Nery García Zárate School was set up in Oronccoy, and new teachers and new teachings arrived. The students were already mature, and their thinking was also mature. They were very obedient. I very happily enrolled my son in the Oronccoy school, but the teaching was not good. My son told me later that they drew the hammer and sickle, they had them read books by Mariátegui, and they talked about Mao. So, the school was politicized. Very worried, I transferred my son to a school in Andahuaylas. The director of the school in Oronccoy was from Ayacucho, and his wife also taught there, they were involved with Shining Path politics. The school put new thoughts into the heads of the inhabitants and the students - they were already rebels, already you couldn't trust them. One teacher had a weapon and held meetings with his students at night. The students were already thinking differently, speaking ill of the government and forming youth gangs, going to neighboring villages.

In 1978, the Túpac Amaru II school was built in Chungui, as there hadn't been a school for the community children. The teachers were from Ayacucho and they taught politics. One teacher carried his weapon and always had political books with him. The students already knew about the politics of Sendero. ${ }^{9}$ — Testimony by S.P. and F.C. 


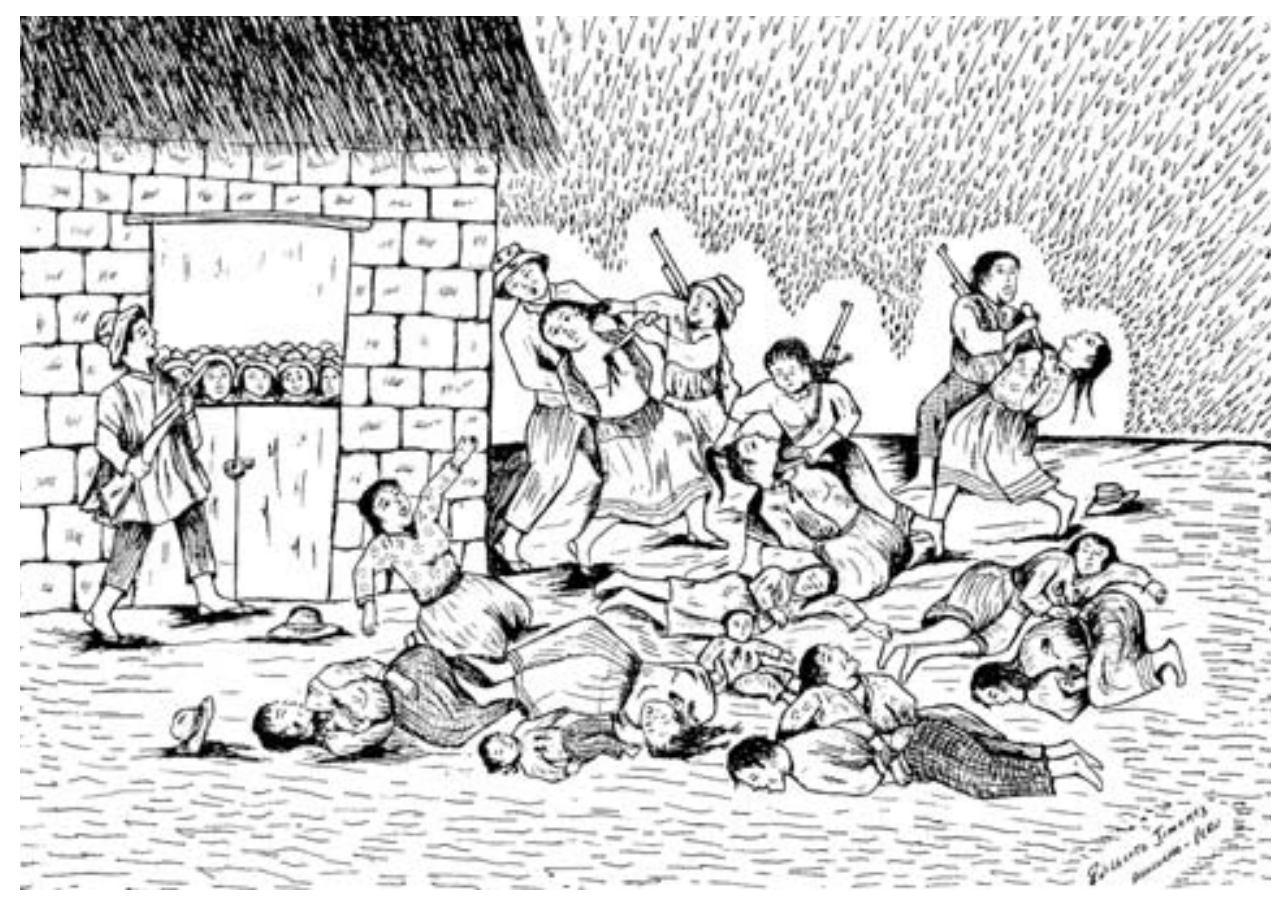

The Senderistas Sacked Yerbabuena

(Yerbabuena, Chungui, May 12, 1984)

The members of the army organized the comuneros into the civil self-defense committees [rondas] to confront the Senderistas.

In May 1983, some hundred Senderistas entered the village of Yerbabuena around midnight, when the inhabitants were sleeping all together in the school. The Senderistas immediately took them prisoner and hog-tied them, even the women and children. The Senderistas scolded them for having formed the patrol [ronda]; then, bringing them out one by one, the villagers were turned over to a column of Senderistas who were waiting outside the school. They [the Senderistas] beat them and then stabbed them. Many mothers and fathers died alongside their children. The massacre lasted more than four hours, and then at dawn the Senderistas searched and looted the homes. Afterward, they withdrew from the village, naming and imposing a villager as a representative of Sendero. ${ }^{10}$

- Source of testimony not indicated. 


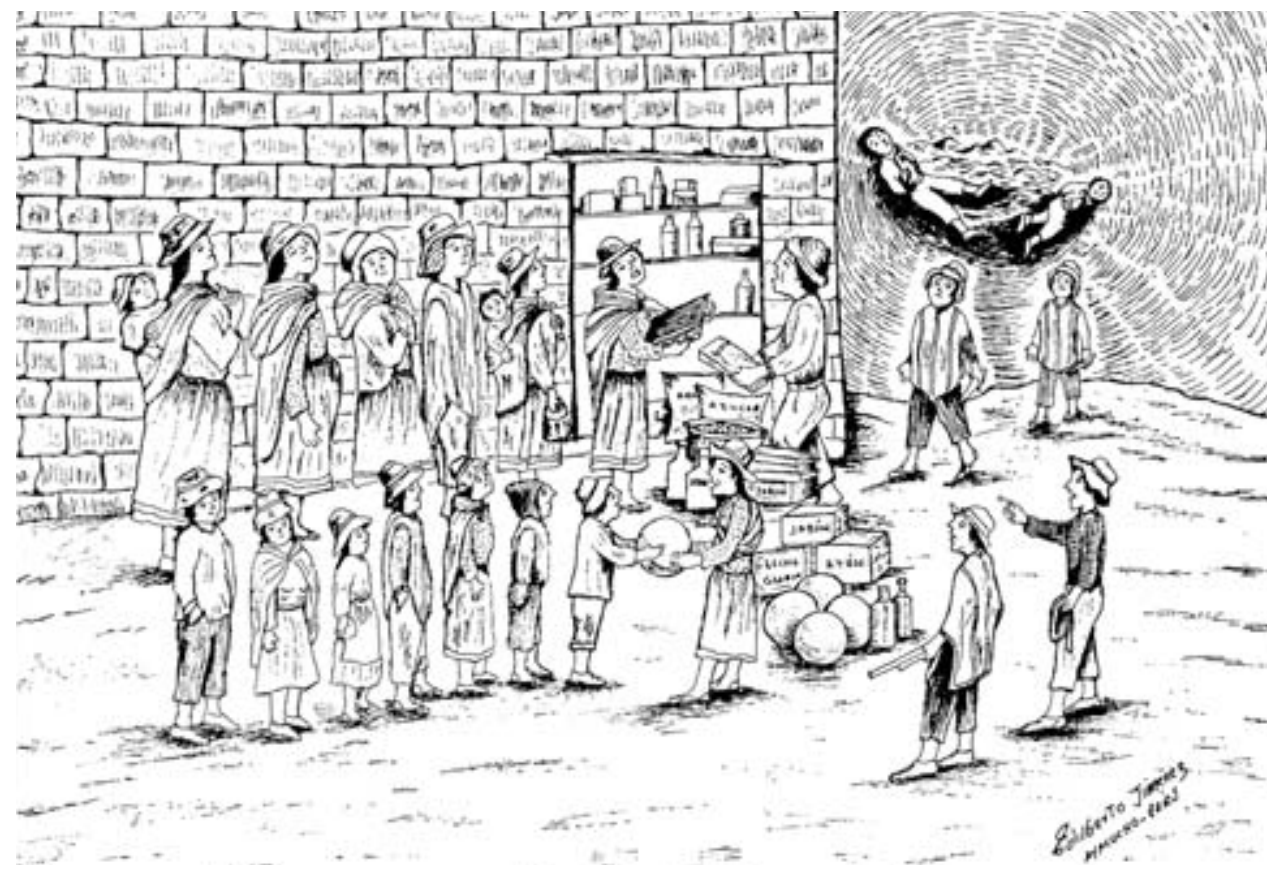


Comrades, Two of the Good-for-Nothings [Miserables] Have Already Left for San Pedro (Chungui, December 14, 1983)

Sendero forces came to Chungui in December 1983, and then they went to the Oreja de Perro [Dog's Ear] hacienda. As they traveled, they killed villagers. In Churca they killed Señor Zenobio Argumedo and his wife, saying that he was an exploiter [gamonal]. In Santa Rosa de Marco they killed the judge, Don Justiano López, calling him an abuser.

In the morning of December fourteenth, they returned to Chungui and said to me "Compañera, there will be an assembly in the plaza at four this afternoon." They told everyone. They said that Sendero had received complaints and that they were watching Señor Andres Raúl Juárez Fuentes and the president, Leonidas Roca Lizana, because he hadn’t renounced his post as president of the peasant community.

In the assembly they said, "Compañeros, with the Party [Sendero Luminoso] there will be no rich or poor, we will all be equal, we will all eat meat, rice, bread, and there will be no inequality. There will be no abusers, exploiters; the armed struggle and the Party [exist] for these [reasons]."

We were all in the plaza, and they didn't let anyone leave. They were armed. After, already late, they said: "Compañeros, two of the good-for-nothings [miserables] have already left for San Pedro. The Party will punish the abusers and the disobedient." Then, they made everyone line up, one for children only, and another one for adults. After, they went into Raúl Juárez's store, took everything out, and divided it up among us: sugar, oil, soap, clothes, sandals, hats, candles, and after they began to drink alcohol and get drunk, making us play music.

We looked for Don Raúl and Don Leonidas Roca. They were already dead. Around five in the afternoon they had killed them. We found Raúl Juárez in his house, in the middle of a pool of blood, covered with stab wounds and cowhides, and Don Leonidas we found also stabbed to death in the old municipal house. They had killed Raúl, saying he was an abusive gamonal, and then the president for not renouncing his post.

This was the first killing: we buried them crying, and later we were all scared of the [Senderista] compañeros. And, out of fear, we stayed with them until the military arrived and organized us in civil defense groups. ${ }^{11}$

- Testimony by C.V. 


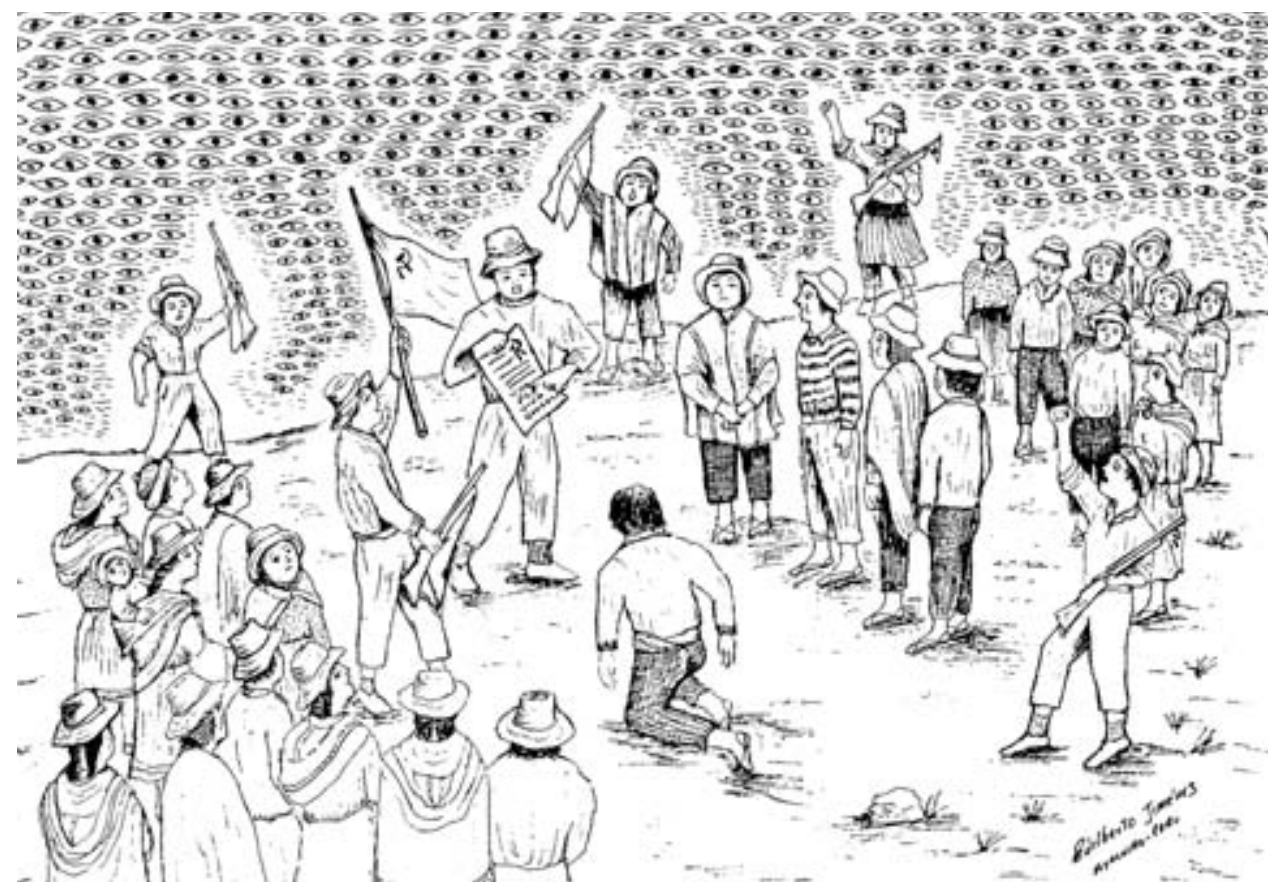


They Said, "You Must Obey Those in Charge"

(Chillihua, Chungui, 1984)

In the afternoon, more than thirty comrades arrived in Chillihua; they gathered the inhabitants in the communal meeting house and they said that they were fighting for the poor, that they were the new government, that they would maintain order, that now the Belaúnde government was useless, the president is Comrade Gonzalo.

They made everyone join the Party [Shining Path], and they said that only the rich hate the Party, and that we had to kill the rich. [They said that] the Party had a thousand eyes and a thousand ears, no one could scoff at the Party of the poor. They spoke of wonderful things, and they warned that the enemies of the people were corrupt people, rapists, pickpockets, and beguilers, and that they should be annihilated.

These travelers were strangers, they weren't from Chungui; their leaders spoke only Spanish. So, silent, we had to accept. We had heard that these travelers had killed those who refused them. In Chupón, they had already killed the authorities; there was much fear.

They gave us their pamphlets on belonging to the Party and they named their deputies for every village.

In Chillihua, too, they named three representatives then said "You must obey the deputies, they are the authorities of the village." The new appointees very quietly knelt and thanked them, and they all hailed the Party: "Long live the Communist Party of Peru! Long live President Gonzalo! Long live the armed struggle!" and they raised their fists. Among the group of comrades were women and youths.

The flag was red with the sickle and hammer: they said that the sickle was for the peasant and the hammer for the workers. They left in the night in the direction of Occoro. Afterward, the new deputies were the local representatives of the Party. They made us leave the community [forced displacement or las retiradas]. ${ }^{12}$ Later other leaders from the Fuerza Principal and from the Fuerza Local came and they all conversed with our deputies. ${ }^{13}$

- Source of testimony not indicated. 


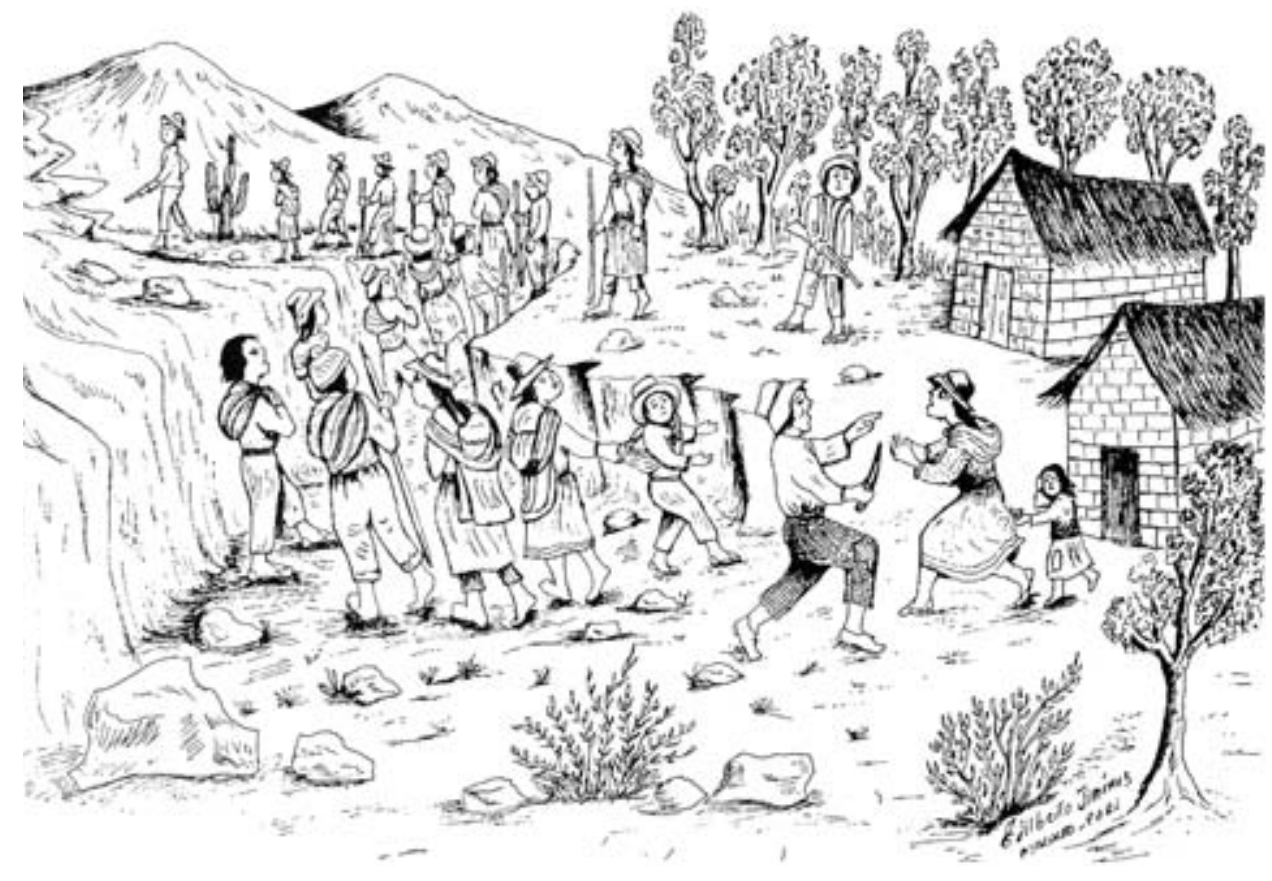


They Would Have Killed Us If We Didn't Go with Them (Chungui, 1985)

Shining Path would enter the villages and, with threats of death, conscripted the children without their parents or their families being able to do anything about it:

I was barely eleven years old, and my sister fourteen, and she had recently come from Lima to visit us. Together with my parents, we went to Lechemayo (Anco) to sell our cacao and peanuts.

One morning, the comrades came, shouting, and they killed my father, tying his hands with rope, they stabbed him in the chest with a knife, calling him a good-for-nothing [miserable]. Then they grabbed us and were going to kill us if we didn't go with them. My mother pleaded with them, weeping, almost fainting; but they threatened to kill her as well, so that we would agree to go, my sister and I. My mother could do nothing, and she kept crying and begging them not to harm us, and she wept along with my five-year-old little sister.

We couldn't escape: they changed our names and gave all of us children comrade names. I was then Raúl and my sister Carmen and they made us carry a bag - we made it out of cloth and we embroidered it with the hammer and sickle. We walked with our bags from village to village and in them we carried our pamphlets or supplies.

Very early one morning we came to a little village in Anco-I don't remember its name. And the other group of our comrades also arrived, so we joined the two groups and we were numerous. But the commander sent many of my friends to the other group, and they made my sister join the other group. There for the last time we looked at each other and said goodbye, from that moment she disappeared.

Though I was very sad without my sister, I could not cry, it was forbidden to cry. For a year I experienced a lot of suffering as part of the Fuerza Principal of the Party. The little ones' mission was always to shout Long live Gonzalo! Long live the armed struggle! Long live the Communist Party of Peru! $!^{14}$

— Testimony by L.M.L. 


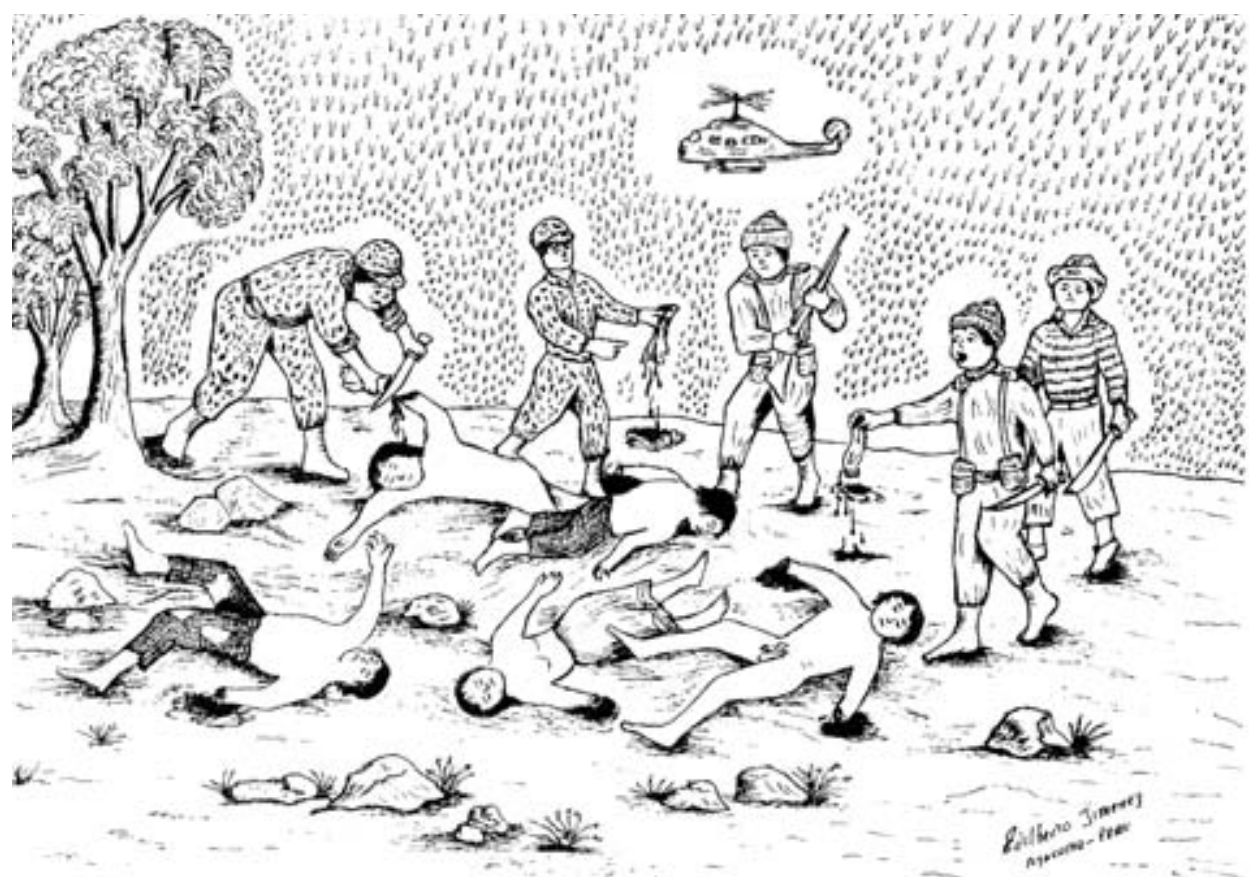

They Cut Off Hands and Ears to Show to Señor Government (Oronccoy, Chungui, 1985)

Ay, life-it's hard to remember; I don't want to remember this life of death anymore. We lived like vizcachas [Andean rabbits] in holes. Hiding whenever anything happened - you had to run and hide as best you could. If helicopters came, then you had to hide so they wouldn't see you. The helicopters brought the soldiers, brought the sinchis. They hunted us like deer to kill us, to abuse the women; they burned our houses, our crops of corn and potatoes.

They were like children of the devil. If they found us, they killed us like dogs, like toads they threw us into ravines; they respected neither women, nor children, nor the elderly. After killing, they still cut off the hands and the ears, and they took them by helicopter to show to señor Government. It was said that when they delivered hands and ears, the government paid them a lot of money. 
I saw how the sinchis killed Don Ismael Huamán, in Limonpuquio-Chapi, and then they cut off his hands and they took them.

The sinchis, after killing, cut off their hands and ears to give as proof to their superiors, and it was also said that it was a point of pride for them to have a hand, an ear, as a trophy in their rooms, and, for this reason, they cut up their dead.

Life wasn't worth anything: them going about in the helicopters and us hiding. No one protected us. They hunted us like animals. And, to this day, we live forgotten.

I had gone to see my family in Toqaruwuay-Oronccoy: the soldiers and civiles $^{15}$ killed Pedro Casa and cut off both hands and his ear. They did this so they could say that they had killed terrorists, so that their bosses would promote them in rank for having killed, and for this they cut up those wretches. ${ }^{16}$ -Testimony by J.C.C., T.B., and R.O. 




Those Sinchis Killed Them to Steal Their Livestock (Oronccoy, Chungui, May 1985)

Our life wasn't really life, there was no one helping us. To stay alive we had to go to the mountains, the ravines, the caves, to anywhere-running like deer to hide, because the sinchis and the civiles were looking for us to kill us, to take our belongings and our livestock.

My uncles, my relatives, and some of my fellow villagers - more than thirty 
people-had escaped to the Cabracancha area, while I was in MollebambaOronccoy with my sick wife and young children.

Cabracancha is lower down than Oronccoy, and it's difficult to get there if one doesn't know the path well: it's between shrubs, boulders, and ravines, but from Cabracancha one can easily get to the Pampas River. Here they were with their cows, horses, and sheep, thinking they were safe. But those civiles and the sinchis from Mollebamba, they arrived very early in the morning and found me there. I jumped into the gully and managed to escape, but they killed my wife and my little children.

I ran and I ran to let my uncles know who were in Amanqaykuchu, but I was too late: the sinchis had already shot them. More than twenty-five people died with their children-like my aunt Felipa Balboa, Agustina Rimachi, and Eusebia Lima Pahuara.

Later I tried to get to Cabracancha to warn them, but it was all in vain. The sinchis had already arrived, using a prisoner as their guide. There, in Cabracancha, they rounded everybody up and, without pity, they shot them all, and they all died. Some had thrown themselves into the ravine, and they died. A few managed to escape.

Those vile sinchis: children, women, the elderly - they killed them, and then, like savages they destroyed their pots, pans, jars, and gourds - all shot and broken up, they just left them. After killing everyone, they rounded up all their livestock - cows, the sheep, their horses — and they took them to Mollebamba. The civiles took their cheese and blankets, and then, like thieves, they left.

The people were innocent. Those sinchis killed them to steal their livestock. I remember the dead in Cabracancha, my aunt Catalina Rimachi (55), Esteban Rimachi (40), Concebida Lima Rimachi (32), Aurora Lima (28), Santona Lima Rimachi (14), Jerónimo Lima Rimachi (18), Estela Rimachi Casa (38), Carlota Casa Azpur (40), Soraida Rimachi Urbano (5), Benedicta Urbano Escarcena (35), Paulina Lima Rimachi (9), Simeón Rimachi Ventura (5), Esteban Rimachi Urbano (20), Sabina Rimachi Casa (48), Félix Cuadros Huamán (30), Fausta Ramírez Huamán (32), Santiago Lima, Guillermina Tello, Josefina Ramírez, Carmina Ccaicuri, and others. ${ }^{17}$

-Testimony by D.R. 





The Black and White Lice Were Exterminating Us

(Huallhua, Belén Chapi-Chungui, 1986)

We had been in the mountain for more than four years, by then almost without clothing. Those in the Fuerza Principal didn't bring us anything anymore. When somebody got pensive, or they [members of the Fuerza Principal] believed someone wanted to surrender, they would kill him and give you his clothes, stained in blood, so that you used them. This was suffering. The hunger was so bad we'd eat anything.

We didn't have anywhere safe to stay, we just moved from one place to another. We couldn't clean ourselves - we didn't have soap or detergent-so we were stinking. Our dirty bodies, our dirty clothes, were reeking.

Our hair grew and we cut it with a knife because it was difficult to find scissors. Our soap was the suyrurus, the fruit of big trees, ash, the bulb of the San José flower, or we also ground the root of the taqsana plant. With that we'd wash our clothes, but it never got rid of the dirt like soap or detergent would. We always suffered for the lack of clothing and soap, and so the lice covered us and we were lice-ridden. The orphan children were the most lice-ridden and so we'd sometimes boil the orphans' clothes in a big pot so as to kill the lice.

Black fleas, like from pigs, also covered our heads because our hair was so long and dirty. The fleas covered us and we had to take off our clothes to kill them. We'd sometimes leave our blankets out in the sun to kill the fleas with the heat of the sun. Living like animals, in caves and mountains, and sleeping together like dogs or pigs, the black and white lice drove us mad. Our bodies were the white lice. We were so dirty that our stench could be smelt from far off. ${ }^{18}$

— Testimony by V.C.Q and T.B.P. 


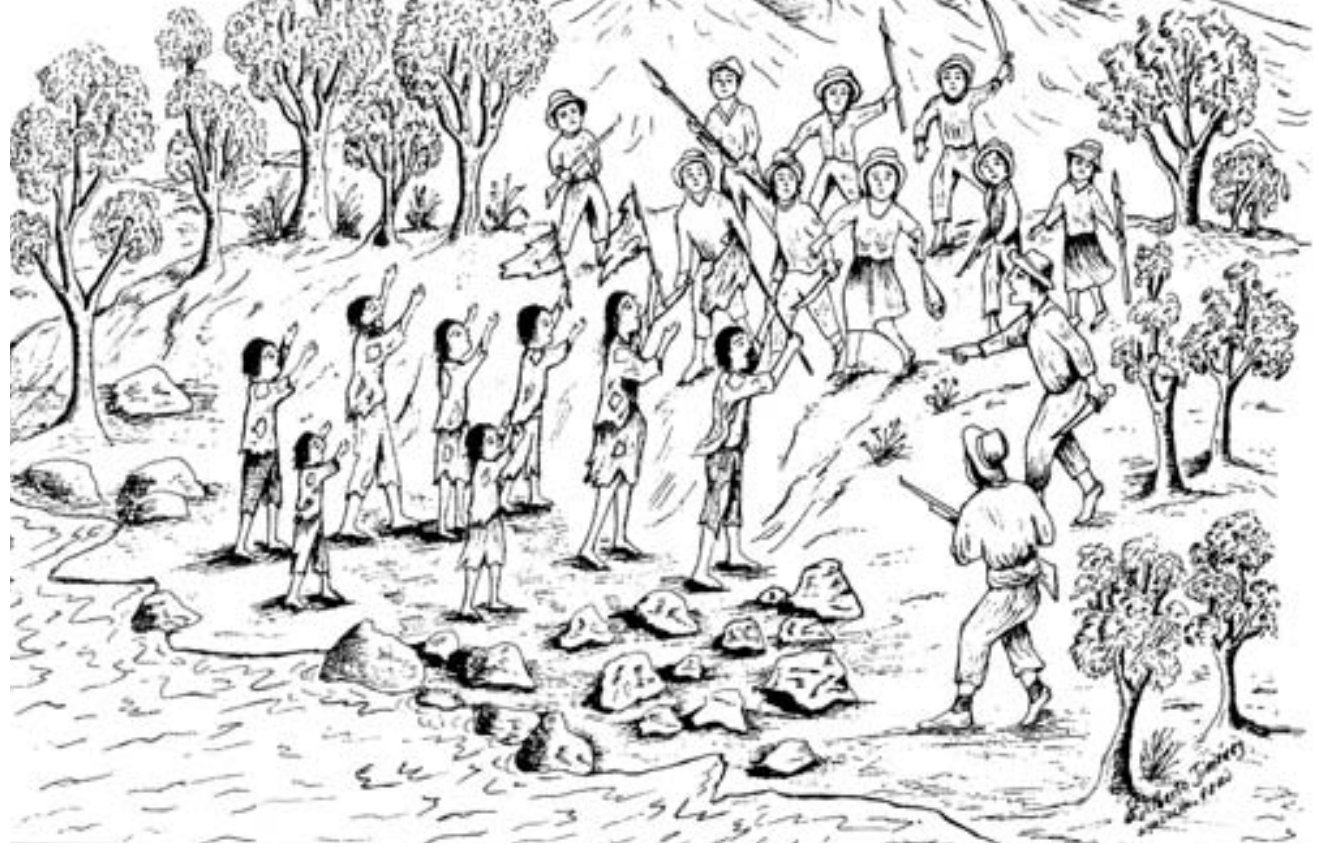


We Surrendered Ourselves to the Ronderos in Ocobamba (Ocobamba, Andahuaylas, 1986)

The Civil Defense were already known as ronderos, and over time they got more murderous. We'd heard that the ronderos of Andahuaylas were more humane than those in Chungui, and we decided to give ourselves up to the ronderos in Ocobamba. More than twenty of us had escaped the Senderistas. In two days we made ourselves wood rafts, and with great difficulty, we managed to cross the Pampas River while the water raged because it was the month of the rains.

Our worry was how to give ourselves up to the ronderos. We were thinking, they'll kill us for sure. We decided to tie our white shirts and cloths to a stick and that was our sign that we were innocent. This was our flag.

Someone saw us and immediately mounted his horse and galloped away down the path. It seemed our luck had run out as after a few minutes more than fifty ronderos from Ocobamba appeared, armed with machetes, slingshots, and spears, ready to kill us. They cornered us and we tried to explain to them our fate, with our hands up and [holding] our white flags. The women, crying, pleaded for them to help us. We'd escaped from the hands of the terrorists, we told them. They looked us over from head to toe: we were skinny, ragged, covered in lice, and hungry. Luckily, they saw the Senderistas who were following to kill us, and they believed what we told them, our truth. They took us to the village of Ocobamba, where the village authority had food prepared for us. We ate soup with salt for the first time in four years.

We told them our whole story. They asked us to help them with their chores and grazing their livestock. We helped on their chacras [fields] and we went out to keep guard, together with the ronderos. Our lives had changed. ${ }^{19}$

- Testimony by E.C. 


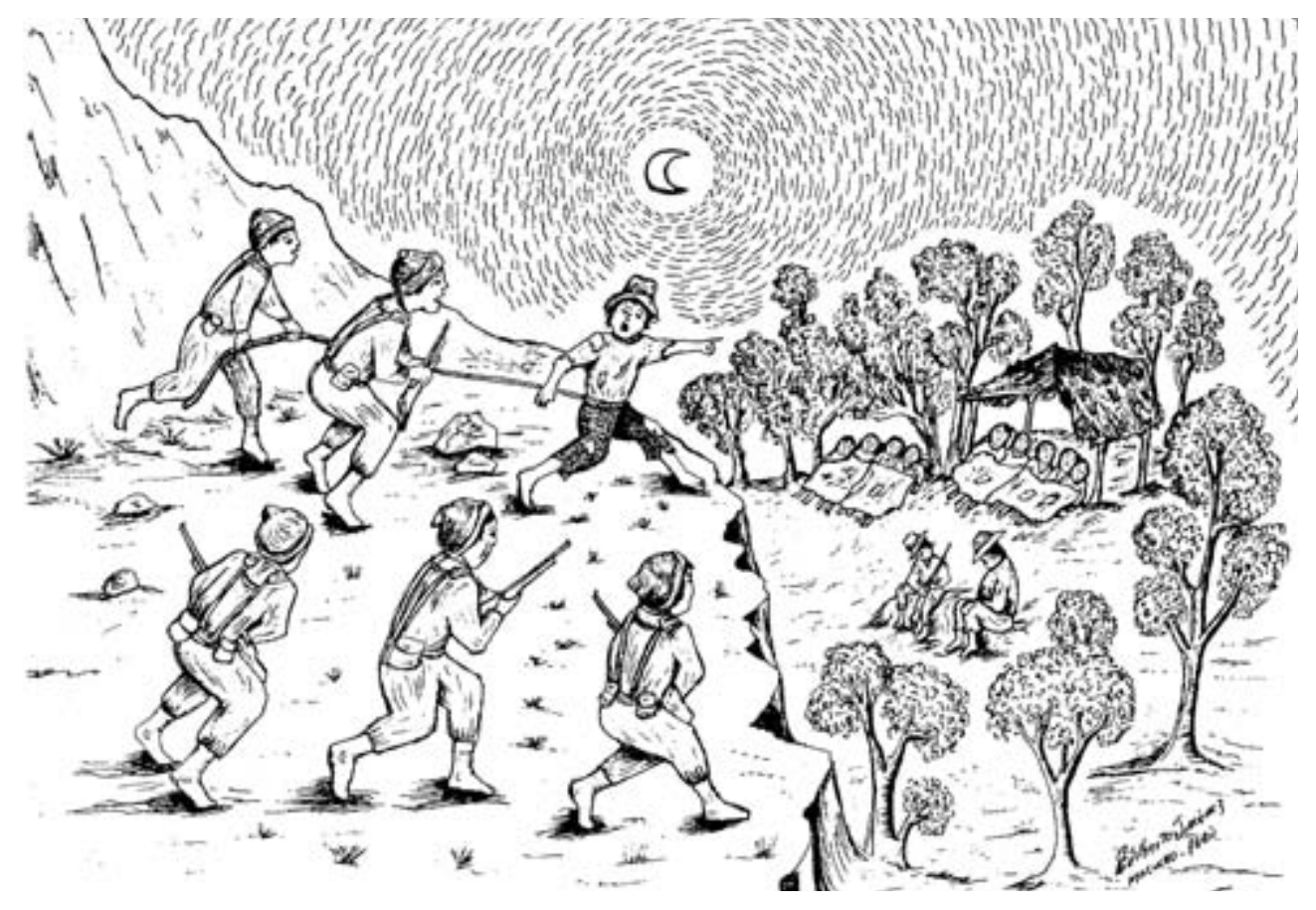

We Came Well Prepared to Capture the Subversives (Belén Chapi, Chungui)

On May 11, 1986, I was conscripted [into the army] and they took me to the Caraz (Ancash) barracks. On May 12, they took me to Fort Rímac, in Lima, and by May 27, I was in Ayacucho. On June 15, they sent a hundred of us recruits to Andahuaylas. For close to three months, I was in nonstop training in the Andahuaylas barracks. They were always speaking about Chungui, which was a red zone, and of Comrade Aurelio, the leader of Base 14 in the Chungui and Anco districts. We heard reports of soldiers dying and we feared going there. A captain who was the barracks doctor asked me to travel to Chungui to be a medic. I went there the first time on April 8, 1987, at the rank of sergeant. They called me "Trapster" [Trampero] because I was a specialist at setting up traps to capture subversives.

In Chungui, I worked as the base's medic. Those of us who'd just arrived were apprehensive as it was a dangerous, red zone. Before getting off the 
helicopter there, we were thinking we'd either win or die. We couldn't trust anybody, not even people from the Civil Defense, because they'd betray us. We arrived well prepared to capture the subversives. In October, we left the Chungui base for the Chapi zone with a patrol of fifteen well-equipped soldiers - each soldier with one hundred bullets - under the leadership of Captain Búster, and along with more than fifty ronderos carrying their spears, knives, and slingshots. I carried the first aid for hemorrhages, malaria, typhoid, and sutures. In Chapi, we saw with our binoculars that in the Incahuasi sector there was a woman and a child acting as lookouts for the Senderistas. We immediately surrounded and captured them. To our surprise, it was actually a man dressed as a woman: it was Comrade Melesio, and we tied him up with rope. We punished him and he offered to take us to his camp. In the night, he took us to the camp, close to Vista Alegre. On the way, we captured two night lookouts who'd fallen asleep. Together with the two captives, we got to the camp and saw a bunch of Senderistas sleeping, just like their lookouts. We surrounded the camp and got our prisoner to wake them up. There was no escape. They looked at us and asked us not to kill them. The captain told them their lives would be spared if they cooperated, that only those who tried to escape would be executed. We brought about thirty-five people to our camp in Chapi and there we provided them with first aid. At night, we went out to capture more camps in Vista Alegre and Panto.

In barely a week, we captured a total of 190 subversives - including children, women and men - totally malnourished, sick, with torn clothing, lice, children full of intestinal parasites and scabies. Without harming them, we took them to the military base in Chungui, from where many left with a guaranty [of safe passage] to their benefit. ${ }^{20}$

- Testimony by C.A.V. 


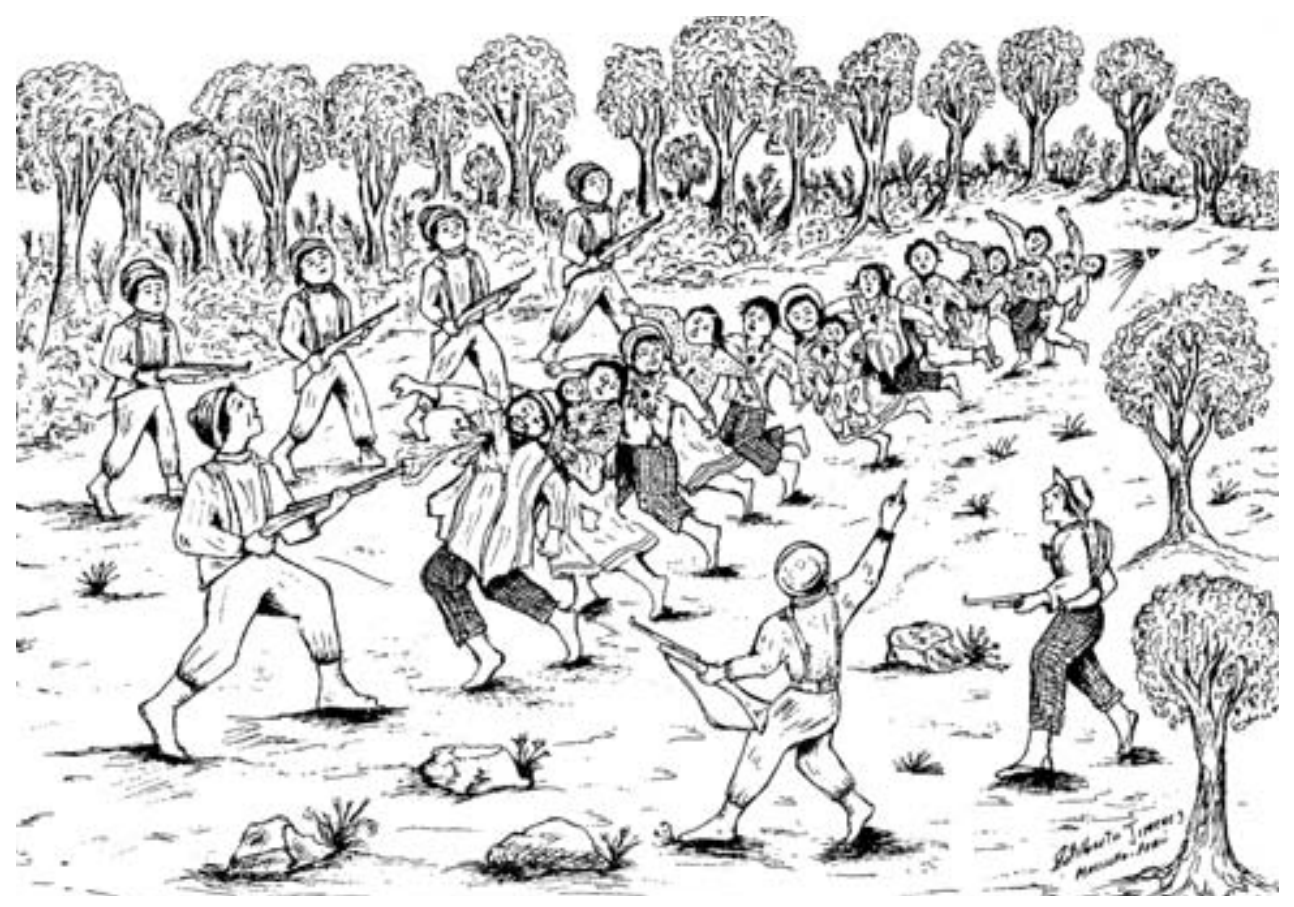

They All Died with One Bullet

(Belén Chapi, Chungui, January 1985)

I am a graduate of the Infantry. I served in the army in Lima, in the cavalry. I know Lima well. When the military arrived in Chungui, they always called on us to serve the army, saying that we are graduates, and when they showed up, we had to present ourselves. Later, we served as guides for all regions, and if not, they would call us terrorists. Obedience was remaining quiet; you couldn't say no, if not you were a terrorist [terruco] and they'd kill you.

In April 1984, Captain Rivas came to Chungui with the mission to terminate the terrorists, and to organize us into a civil defense, and he obligated me to be guide. We walked with the military patrol to the Chapi zone. We walked for more than a week, in the day we rested and at night we looked for terrorists without making noise; quietly we walked between the trees. One day, at around four in the morning, we captured some terrorist lookouts, because sleep had overcome them and they had fallen asleep. They were two men 
and one woman. The military interrogated them with blows and with death threats. But the prisoners offered to take us to their hiding spot, which was very close by. We arrived at their camp very early; it was in the Chaupimandor region.

We found them making roofs of banana leaves for their shacks. Women were preparing their meals, there were more than thirty-five people, including women, the elderly, and children. Quickly, we rounded them up, hands up and everyone on the ground, now they couldn't escape, only beg. They said that the Senderistas made them hide in the mountains. They cried not to be killed. The military didn't believe them, for them [the military] everyone was a terrorist and should die. They ordered that they all file into single line immediately, and that they hold their children against their chests.

Poor ones. They thought that we were going to take them to Chungui, and I also said in my mind that surely we were going to take them as prisoners. But later, this wretched lieutenant [teniente miserable] ran in front of the line with his big AKM rifle, and he shot one single bullet, and this bullet went through everyone in the line. They fell to the ground dying, others in pain. Most had their chests, stomachs, and heads destroyed. All died with one bullet and no one survived.

After killing them, they left them there, without burying them. It gave me a human pain to see children, women, and men die with a single bullet in a pool of blood like any old animal. The military said that the terrorists should die; it's the death penalty for them. ${ }^{21}$

— Testimony by J.N.A. 


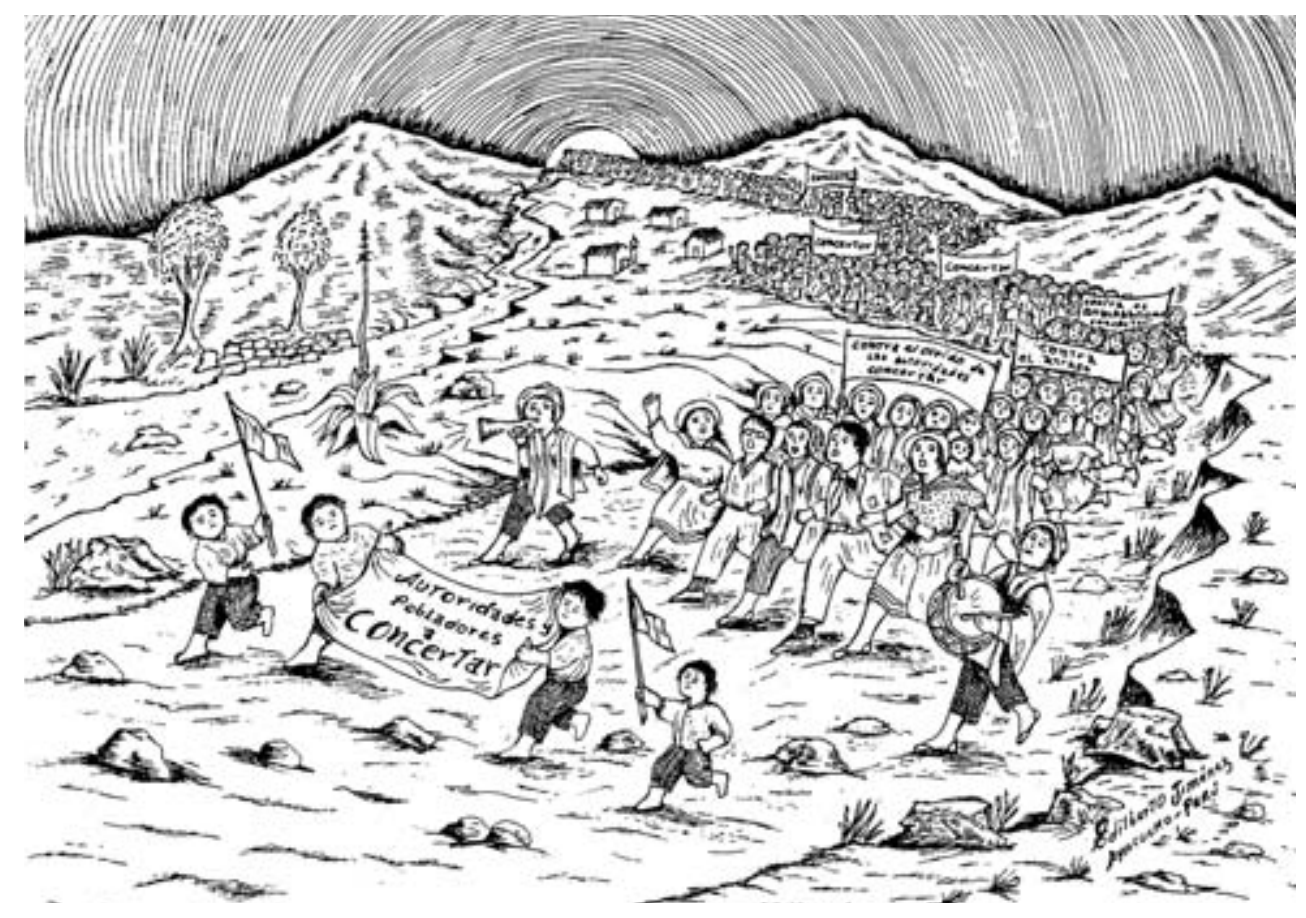

Working Together

(Concertación)

Edilberto Jiménez's concluding remarks and drawing from Chungui, 2005:

After the internal armed struggle, the peasant communities remain marginalized and forgotten by the state. This [last] drawing shows that the authorities and the people must work together [concertar] in order to end poverty, illiteracy, sickness, and backwardness, and to achieve the development of their communities. ${ }^{22}$ 


\section{Notes}

1. There are two versions in Spanish of Edilberto Jiménez's Chungui. This chapter is based on the 2005 version.

2. Between 1983 and 1994, 1,384 Chungui community members were killed and disappeared. See CVR, Informe final, vol. 5, chap. 2.3.

3. On Jiménez's retablos see Ulfe chapter here, and Golte and Pajuelo, Universos de memoria. On music from the Víctor Fajardo region, see Ritter's chapter here.

4. On these retablos see Ulfe's chapter here as well as Ulfe, Cajones de memoria, and Milton, "At the Edge of the Peruvian Truth Commission," 21-26.

5. Prior to publication of his drawings, Jiménez used to hand out photocopied versions. This speaks to the urgency he felt to bring attention to the plight of Chungui, a region where he continues to work as a member of an NGO.

6. Municipalidad Distral de Chungui, "Mejoramiento y ampliación del sistema de agua potable, e instalación del sistema de alcantarillado y tratamiento de aguas residuales en el centro poblado de San José de Villa Vista, Distrito de Chungui-La Mar-Ayacucho." Available at the Ministry of Economics and Finances website, http://ofi.mef.gob.pe /appFD/Hoja/VisorDocs.aspx?file_name=3328_OPIMDCHUNGUI_201242_101222.pdf, accessed July 12, 2013.

7. Vergara, "La memoria de la barbarie en imágenes," in Jiménez, Chungui, 18n. 8.

8. Degregori, "Edilberto Jiménez," in Jiménez, Chungui, 16.

9. Jiménez, Chungui, 70-71, all translations are by Katherine Saunders-Hastings and Cynthia E. Milton.

10. Jiménez, Chungui, 72-73.

11. Jiménez, Chungui, 8o-81.

12. The retiradas was the forced displacement of people away from their communities by Shining Path so that they could not be reached by the armed forces.

13. Jiménez, Chungui, 84-85. The Fuerza Principal and the Fuerza Local were action groups of the Communist Party of Peru-Shining Path. The Fuerza Principal was made up of mobile columns, armed and led by Shining Path's political and military command. Local Shining Path activists in each community with lesser weapons formed the Fuerza Local. After completing an armed action, they would return to their agricultural practices. A third level of the Shining Path was the Fuerza de Base or participating town residents who did not have firearms but carried machetes, spears, and basic supplies. They had various commissions: to keep watch, to threaten and intimidate, and to accompany the Fuerza Principal and Fuerza Local when they made incursions into other communities. See cvr, Informe final, vol. 2, 131.

14. Jiménez, Chungui, 150-151.

15. The original text reads "los militares y los civiles mataron." "Civiles" most likely refers to the Guardia Civil (Civil Guards), one subsection of which were the sinchis. 
102 / EDilberto Jiménez QUispe

16. Jiménez, Chungui, 16o-161.

17. Jiménez, Chungui, 166-167.

18. Jiménez, Chungui, 176-177.

19. Jiménez, Chungui, 190-191.

20. Jiménez, Chungui, 196-197.

21. Jiménez, Chungui, 202-203.

22. Jiménez, Chungui, 208-209. 
CHAPTER THREE / MARÍA EUGENIA ULFE

NARRATING STORIES, REPRESENTING MEMORIES/

RETABLOS AND VIOLENCE IN PERU

t was Friday, August 29, 2003. For the previous five days almost fifty people had worked to build a stage on the main plaza of Huamanga, Ayacucho. ${ }^{1}$ Just the day before, the Truth and Reconciliation Commission (Comisión de la Verdad y Reconciliación; CVR) had submitted its Final Report in Lima. The following morning, August 29, the twelve commissioners and the philosopher Salomón Lerner Febres (who presided over the commission) traveled to Huamanga to present their report describing twenty years (1980-200o) of Sendero violence, military repression, and authoritarianism. As a crowd began to gather in Huamanga's central plaza, waiting in the hot sun, a kind of anticipation and excitement brewed in the air that stood in contrast to the previous night's solemn candlelight vigils there. Though some minor confrontations took place with groups who contested the work of the CVR, for the most part the occasion seemed festive, with bottles of water and ice cream being sold to keep the crowd cool. By midday, the commissioners solemnly took the stage and presented their report in both Spanish and, through the help of a translator, Quechua. ${ }^{2}$ Lerner began his speech with a reference to reciprocity: he said that for the past two years the commissioners had received the testimony of Ayacuchans and other Peruvians, and now the CVR was returning to give "testimony of their own journey" as commissioners. ${ }^{3}$ Lerner thus handed the CVR's report to the people of Ayacucho, those Peruvians who had suffered most during the years of political violence and repression.

The place where the CVR commissioners chose to present their Final Report is of more than symbolic importance: the Maoist Communist Party of Peru, Sendero Luminoso, had begun its armed struggle in 1980 here in the department 
of Ayacucho, and Ayacucho alone accounted for 40 percent of the victims of the ensuing conflict. Yet the CVR's choice of stage for the purposes of this public homage was symbolic: set designers - including members of the theatre troupe Yuyachkani-built a two-story triptych box with open doors, known in its smaller format as a retablo. The commissioners transformed this highland artform of the retablo into an enormous stage on which to present their own work, the CVR's Final Report. By doing so, the commissioners and set designers expanded the use of the retablo as a regional artform that spoke of regional issues to a national platform for a discussion of the war years. While novel in its size, the use of the retablo by the CVR as a medium for truth-telling was not unique: Ayacuchanos had been using retablos (along with other highland artforms) as a means to recount experience, in particular political transformations, since the $1970 .{ }^{4}$ It is interesting, however, that the CVR chose to frame their ceremony of the handing in of the Final Report within a monumental retablo, a regional artform, for a national effort at truth and memory.

Why was a retablo used as a national platform for truth-telling? The retablo, both literally and symbolically, set the stage for addressing contemporary politics and culture in Peru. Yet what makes retablos, an expression of highland, traditional art, and in particular Ayacuchano art, so special as to be employed in this important symbolic act? Are retablos malleable enough for addressing a national audience, especially since for most of their history they have been deemed "popular" (meaning "folk") rather than "fine" (implicitly "national") art? Most important, what does the use of the retablo for the purposes of truth-telling tell us about political struggles in the construction of social identities taking place in Peru today? By addressing these questions, this chapter attempts to problematize the polarity between "folk" and "fine" arts in order to contribute to the debate on the construction of memory through visual art.

\section{The Transformation of Santeros to Retablos}

The retablo has a long history as a cultural practice that seeks to speak to highland audiences. The origins of the retablo date back to Spanish missionaries' efforts to convert indigenous peoples to Christianity through the use of images. ${ }^{5}$ In his work on colonial Mexico, Serge Gruzinski studies the ways priests used paintings, sculptures, and engravings to communicate the central tenets of the 


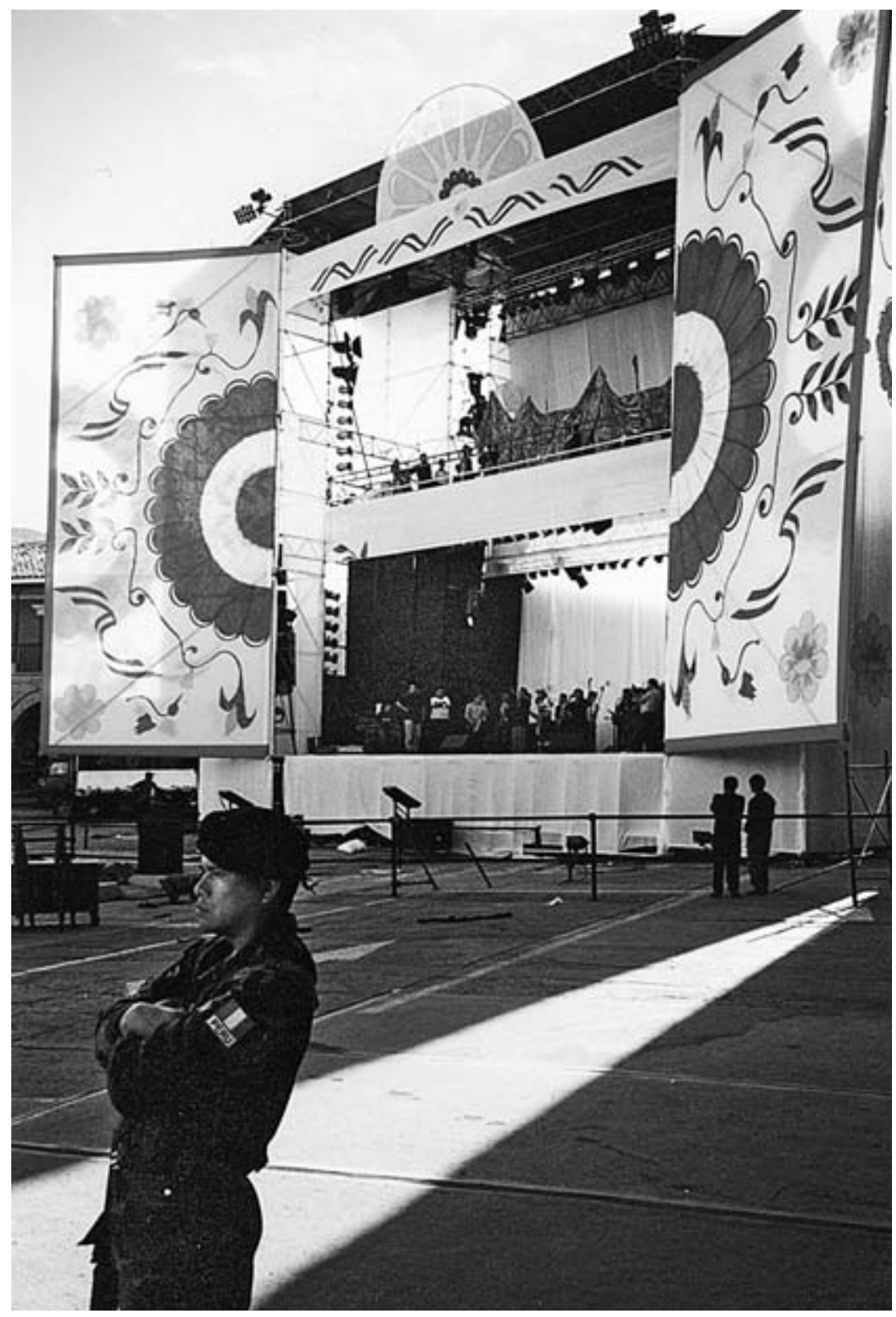

FIGURE 3.1. Setting up the retablo stage for the symbolic ceremony for the release of the Peruvian Truth and Reconciliation Commission's Final Report, August 2003. Photograph by Cynthia E. Milton. 
Christian faith. ${ }^{6}$ One visual form employed in the Andes was the Santero chapel, a single-level wooden altar with the central image of a saint or virgin. Andean artists later transformed Santero chapels into Sanmarcos chapels, which positioned the patron saint, Saint Mark, in the center of the first level of a two-tiered box. The people of Ayacucho also refer to the Sanmarcos box as misa (mass), a term from colonial times when these boxes traveled to highland villages as representations of the Catholic mass. Sanmarcos boxes have also been used in two other contexts, continuing to this day: the ritual branding of animals (known in Spanish as herranzas) and the healing ceremonies of wamani (a mountain deity or spirit).

In the transformation from Santero chapels to Sanmarcos boxes, artists adopted Catholic religious imagery while also altering the meanings and uses of the object. In this process, the Sanmarcos boxes became something else, different from their original form, endowed with both new content and purpose. ${ }^{7}$ In form, Sanmarcos boxes have two levels. Several scholars consider this spatial scheme as a metaphor for the division between an upper or heaven world and this world, drawing on the Andean notion of a three-world system: the upper world, or hanan, this world, and the underworld, or hurin. ${ }^{8}$

In content, images of the patron saints of animals accompanied by a condor representing the mountain deity wamani (sometimes perceived as a foreigner) decorate the first level of the Sanmarcos. Similarly, patron saints and their animals adorn the upper level: Saint Mark, patron saint of bulls; Saint Inés, patron saint of goats; Saint John the Baptist, patron saint of sheep; Saint Lucas, patron saint of lions; Saint Anthony, patron saint of horses, mules, and travelers; and sometimes Saint Santiago (James), patron saint of thunder and owner of cattle. ${ }^{9}$ While the patron saints inhabit the upper level, the bottom level of the Sanmarcos may show religious stories such as "The Passion" or may recreate different stages of the herranza or branding ritual.

As a fluid artform that continued to respond to the artists and their communities' realities, Sanmarcos came to incorporate scenes beyond agricultural and religious practices and became vehicles for the communication of other cultural practices (marriage, marketplaces, fiestas, etc.) and for the expression of political opinions. Thus, Sanmarcos transformed into retablos. This three-stage process- 
the movement of Santeros to Sanmarcos and then to retablos-illustrates Andean cultural adaptation to socioeconomic and political changes, both locally and nationally.

\section{The Retablo as an Object of "Folk" Art}

Retablos initially captured national attention as Joaquín López Antay, the first retablista ${ }^{10}$ gained notoriety beyond the highlands. In 1941, López Antay met the indigenista painter Alicia Bustamante, who introduced his retablos to Lima's art scene. Up until this point, these two-story wooden boxes inhabited by figures of saints and animals could only be found in the Andes. Their introduction to Lima marked an important turning point in this artform.

Changes in the retablo and the struggles of retablistas mirrored, in part, larger national transformations in Peru. The emergence of retablos in the Peruvian art scene occurred simulaneously with the government's quest for modernization in the 1930 and 1940s, migration from the rural areas to the coast, and indigenismo, an elite intellectual movement that sought to vindicate the presence of the "Indian" in the Peruvian nation. ${ }^{11}$ Historian Carlos Contreras describes the period between the end of the War of the Pacific (1884) and the economic crisis of the 1930 as one of modernization of export agriculture and mining. Contreras describes how, with the exception of the trade of wool and rubber, other production sectors also began to operate under a capitalist logic. This affected local populations in various ways: urbanization (between 1876 and 1940 urban populations grew from 17 percent to 27 percent), modernization of urban services, the expansion of state institutions, and the introduction of immigration laws to draw foreign migrant workers to haciendas. ${ }^{12}$ Through various means, the state attempted to change and reach local communities: by promoting education as a civilizing mission, ${ }^{13}$ and by expanding road construction and infrastructure, thus facilitating greater communication between the highlands and the capital. ${ }^{14}$ The historian Paulo Drinot considers Augusto Leguía's presidency (1919-1930) a period of an attempted renaissance of the Peruvian nation, as indicated in Leguía's concept of a "Patria Nueva." For Drinot, Leguía incorporated indigenismo in an instrumental way, selectively considering the past that offered a golden and glorious Inca empire while at the same time developing 
paternalistic cultural policies through institutions like the Sección de Asuntos Indígenas (Indigenous Affairs Division) and the Patronato de la Raza Indígena (Trusteeship of the Indigenous Race). ${ }^{15}$

This process of modernization indirectly influenced the commercialization of Sanmarcos. Prior to the 1930s, only traveling merchants (arrieros) sold Sanmarcos, along their routes between towns. The building of roads, the emergence of new markets, urbanization, and migration weakened the role of these traveling merchants as the distributors of Sanmarcos, in turn affecting the production of Sanmarcos and other religious images (imaginería) that artists like Joaquín López Antay made.

In a way, with changing means of distribution, the encounter between artist, Joaquín López Antay, and art collector and indigenista painter, Alicia Bustamante, was providential for this artform. Indigenistas, like Bustamante, praised the role of the "Indian" in the configuration of the idea of the Peruvian nation, a theme mirrored in the national politics of agrarian reform. ${ }^{16}$ This encounter not only brought attention to retablos but also completely redefined the art. Retablos and retablistas underwent processes of decontextualization. First, Bustamante changed the name of these boxes from Sanmarcos to retablos, the literal translation of which is "altars," since they closely resembled church altars. Along with the new name a series of other changes arose: new topics and scenes were depicted; a monetary value was assigned; artists began to sign their pieces; and retablos were sold, commissioned, and exhibited. There was, however, a paternalism in the patronage of indigenistas like Bustamante; while she appreciated these highland boxes as art, she brought about and guided changes to this artform. And later, in 1977, she seemed to undermine the value she had helped to establish for them: she, along with other artists who had once praised López Antay's art, deemed his work handicrafts and "folk art." By positioning this art as "folk" and artisanal (as opposed to higher genre of "fine art"), Bustamante and others played down the skills and creativity involved in the creation of retablos.

Bustamante's situating of retablos as "folk art" was in response to Joaquín López Antay's winning of the prestigious Peruvian National Prize for the Arts, granted by the National Institute of Culture. Even though, in the context of the time, General Velasco's (1968-1975) nationalist discourse promoted regional art, the established art community, headed by the Association of Professional Plastic 
Artists (Asociación Profesional de Artistas Plásticos), tried to revoke the jury’s decision to award this prize to López Antay. In a series of dissenting letters published in newspapers, they referred to his work as artesanía (handicrafts) - a term charged with pejorative and discriminatory connotations-and claimed that as artesanía his work lacked creativity and self-expression. As a maker of popular (meaning "folk") handicrafts, López Antay was ineligible to receive an award for art, the Association argued. ${ }^{17}$

As García Canclini notes, no specific cultural or aesthetic distinctions exist between popular and fine arts, as their borders are porous and flexible and thus easily lend themselves to experimentation and to borrowing from each other. ${ }^{18}$ However, this debate revealed "popular art" in Peru as a terrain where both the emergence and negotiation of social conflict occurs. In fact, Alfonso Castrillón, a member of the jury, characterized this debate as a conflict between social (and racial) classes: a cultivated high elite on the one hand and an indigenous mestizo urban group on the other. ${ }^{19}$ While the Asociación Profesional de Artistas Plásticos claimed that they simply wanted to clarify the boundaries between these artforms, this debate resulted in an ideological discourse that served to worsen discrimination against the most socially marginalized - the mestizo and indigenous artists from rural regions. ${ }^{20}$

\section{Retablos' Adaptability to Local Transformations}

Change did not come to retablos at the instigation of outsiders alone. By the time López Antay met Bustamante, retablo making had already been undergoing transformations. The processes of modernization of the early twentieth century provoked responses by rural folk, who saw education as a means for individual progress. This historical period coincides with the first migratory waves from the countryside to the cities - a national, physical reorientation in life that must be considered when contextualizing changes in the form and format of retablos. ${ }^{21}$ For instance, in a later wave of migration in the 1960 , the Jiménez family of retablistas left their village, Alcamenca, in search of education and better opportunities in the department's capital, Huamanga. Once immersed in urban life, Florentino Jiménez and his children returned less frequently to the village and thus seldom attended herding rituals.

With migration and fewer arrieros and herding rituals, the saints in the 
retablos lost their original role as religious intermediaries in the middle to late twentieth century. Metaphorically, the box was emptied of content to make room for new central forms and topics. The techniques for creating retablos also changed: instead of using molds, artists started to produce handmade figurines. As a result of this new technique, they began to design more elaborate pieces and develop more intricate scenes.

These changes in technique invite us to consider how artists, in the process of making their objects, endow art with agency. ${ }^{22}$ That is, the artist is an agent in the retablo's production; he or she is an actor in the retablo. ${ }^{23}$ Evidence of this role can be found in one of the last steps in the making of retablos, the sombreado, the stage when the artist adds small final details to the figures: expression to the eyes and gestures, wrinkles to the clothes, shadows here and there, and so on. The artist thereby gives each piece meaning through personal touches that reflect his or her tastes and skills. In fact, one can often identify a retablo's maker by taking note of these details.

The artist's agency is clear not only in the process of design but also in what inspires a retablo and the choice of topic. From the early days of the indigenistas, artists experimented with new themes and forms. Beginning in the mid-1970s, artists like the Jiménez family created a series of retablos dedicated to historical events and social commentary. Pieces made in the family's workshop in Huamanga during these years of changes in retablo form include Cola de Kerosene (Waiting for Kerosene) and Batalla de Ayacucho (Battle of Ayacucho). The artist Claudio Jiménez based the first of these retablos, Cola de Kerosene, on his personal experience of witnessing the long lines housewives had to wait in to buy cooking fuel during Velasco's military dictatorship. The retablo titled Batalla de Ayacucho was made by Florentino Jiménez and his children (Claudio, Nicario, Edilberto, Eleudora, and Odón) in response to a public competition. The municipality of Huamanga held a contest in celebration of the 15oth anniversary of the battle near Ayacucho that had secured Peru's independence from Spain. The Jiménez family based their retablo on material culled from various sources: school textbooks, books, newspapers, and photographs all contributed as important sources of inspiration for their creativity. They won the contest. 


\section{Retablos as Visual Narratives}

After López Antay received the Peruvian National Prize for the Arts in 1976, government officials from the National Institute of Culture introduced a new category eligible for prizes, that of "popular arts," thus separating "popular" from "fine" arts and avoiding future debate. ${ }^{24}$ Nevertheless, not all pieces made by retablistas were accepted under the new category. ${ }^{25}$ For instance, in some national contests, such as Grandes Maestros (Great Masters), jury members would not consider pieces depicting violence or social commentary to be part of the national repertoire of popular arts, effectively denying the presence of conflict in Peruvian society. Unfortunately, the pieces excluded from national contests depicted particularly interesting representations of the internal war that raged in Peru during the 1980 and early 1990 s. $^{26}$

As the historian José Luis Rénique points out, some Peruvians perceive themselves as a sociedad desmemoriada, a society with no historical memory, in terms of inscribed or written memory. ${ }^{27}$ This idea of the importance of written texts in establishing a national memory supports Aníbal Quijano's notion of the "coloniality of power," whereby the present-day exercise of power and social hierarchy maintain certain colonial ideas that effectively discriminate against others. ${ }^{28}$ Indeed, among those who embrace the notion of sociedad desmemoriada-some journalists, politicians, and members of the Peruvian academia-memory (as knowledge of the past) is to be found mostly in the written press and political debates on national television rather than in popular narrations, festivities, or art. The privileging of certain venues for memory discriminates against the vast majority of the population who favor oral and artistic modes over written expression. ${ }^{29}$ Retablos, thus, are largely excluded from mainstream memory debates and the transmission of knowledge and ideas. ${ }^{30}$

One can contextualize the production of retablos by analyzing their depictions as visual narratives, in the sense of created and recreated discourses that show, for example, how violence was experienced and digested by artists - and later expressed in their social commentary and their representations of violence. If we follow Nelson Manrique's argument that many different crises (i.e., economic, social, colonial heritage, representation, etc.) produced violence during 
the 1980 os and 1990s, we could contend that violence itself became a pervasive "object" with which Peruvians had to negotiate. ${ }^{31}$ Some responded by denying the facts surrounding the violent conflict that was occurring in Peru, others by protesting, and many more by rejecting any kind of political involvement. ${ }^{32}$

Retablistas negotiated with violence by converting their retablos into vehicles for communication of their experiences and memories of the violence. Yet artists could only represent violence in their retablos once they had introduced the new techniques of making figurines inside of the box and once they had already started to introduce historical themes (such as the lines for cooking gas and the Battle for Ayacucho) as the retablo's subject matter - changes that had occurred in the 1970s. The main difference between the pieces made in the 1970s and those made in the 1980 s was the violence. In the 1980 os retablos, the violence is represented in its many forms: political (the armed conflict), and social and cultural (in the form of discrimination, racism, poverty, and marginality).

Thus, in the 1980s, retablo art transformed into a political tool capable of conveying ideas about both the past and the present of a fragmented, unequal country. The events depicted were recreated and depicted from the artists' points of view, which were influenced by what was happening in Ayacucho and in the nation during the 1980 s. In the process of imbuing retablos with social commentary, a historical consciousness developed that was based mainly on the artists' lived experiences - individual and collective-and recollection of daily events. Through irony, irreverence, realism, and religious symbolism, retablistas created retablos that became "an alternative source of representation of reality and models of society." 33

\section{Retablos of the Political Violence}

As if a great cataclysm (known as pachakuti in Quechua) had befallen Ayacucho, Claudio Jiménez depicts the fracturing of time produced by the many years of civil war, authoritarianism, and military repression beginning in 1980 in his masterful piece No me destruyas (Don't Destroy Me, Fig. 3.1). For this work, created in 2000, he broke with the traditional format of the retablo, a triptych box, and instead placed figurines on a piece of wood from Ayacucho. ${ }^{34} \mathrm{He}$ carved the central log in the shape of a cross, with the sorrowful face of a crucified Christ. The broken and leaning cross expresses Jiménez's experience of his life 
in Ayacucho as one destroyed by violence. As he explained the year following the creation of this work:

Most important is the social situation in which [we] lived at the time: it was conflict. But this conflict was based on the power of domination. Because of this, the Spaniards dominated us with our Christian faith. That's why [Senderistas] have to destroy it [our faith] in order to win the battle. For that reason, this cross [in No me destruyas] is a fracture of time. ${ }^{35}$

The central image of No me destruyas is a broken, bleeding cross. The choice of the cross probably resonates in Andean communities where the cross is commemorated every third of May. This annual celebration coincides with the harvest, in particular that of maize, since it is believed that crosses protect crops from bad weather by ensuring that the fields "don't get sick." This belief effectively assumes that without crosses to protect the fields and the villages, the domestic economy of the household would be severely harmed. For this reason, villagers place crosses on top of nearby mountains. In No me destruyas, Jiménez placed a cross on top of a small log, similar in shape to a mountain, rather than inside a retablo box. By adapting the retablo artform, he converted the cross into a witness (sitting on the hilltop looking down) and a victim (bleeding) of the conflict. In addition, he depicted the violence as being a different type from that of other historical periods: this violence was of a kind that brought destruction to the villages. This violence destroyed the lives of the peasantry and led to the abandonment of their customs and religion.

Jiménez places the cross of No me destruyas on top of a mountain protecting crops and fields, where Senderistas-here local peasants co-opted by the Shining Path ideology - and military fight, destroying everything in sight. This piece presents an encounter tainted with blood. Jesus's heart (at the center of the cross), the stairs that take him to heaven, and the mortal wound that he exhibits on one side of his body all bleed. The cross is falling over, along with many of these peasants' villages. This scene represents destruction, death, and the social decomposition of the countryside. Without houses, without crops to harvest, without burying relatives and friends, and with no protection from God, peasants run away. Claudio Jiménez explains his complex motivations for making this retablo: 


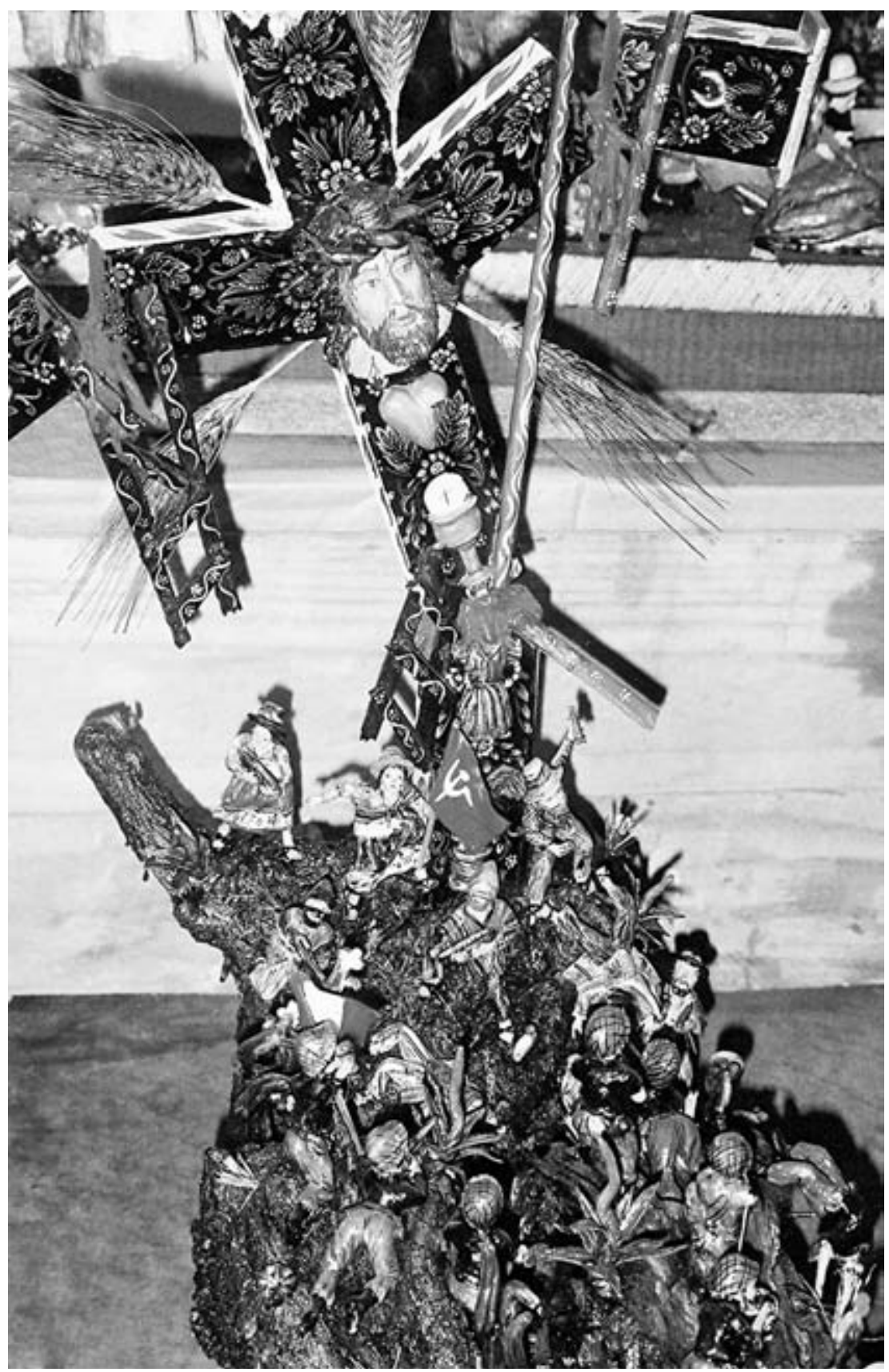

FIGURE 3.2. Don’t Destroy Me (No me destruyas), by Claudio Jiménez. Photograph by author. 
In the countryside, crosses are like a source of hope for farmers; but, what happens is that the Senderistas have influenced the peasants. [Peasants' children] emerge from the universities prepared, since there they study materialism and dialectical materialism, the movement of change. But with dialectical materialism everything is left static since they [the university students or Senderistas] only think about [the problems posed by] religion. To dominate the masses [they think], [thus] the masses have to forget religion. So they [the peasants' children who went to university and return, or Senderistas] start thinking that the crosses have to be destroyed ... In order to beat the military, the Senderistas think they have to destroy religion. In response, the military says: "Put them [the crosses] back in their place" and [in this way] they make the Senderistas disappear. And now, what is going to happen? It is the cross that the peasants are bringing down on themselves. So are the military. The peasants, they are the Senderistas, they are the ones who are destroying the cross. They say "To believe in God is a trick [engaño]." In one part of the Bible, it says "Do not kill," [but] they [the Senderistas] say that [this] is not necessarily [the case] ... That is why they [the Senderistas] kill and in this way; they are destroying the cross, [which they] say is a deception [engaño]. For this reason, no religion. ${ }^{36}$

In this retablo, Jiménez presents a critique of Shining Path's ideology. In his view, the materialism that rural students learned in university-in particular at the Universidad Nacional de San Cristóbal de Huamanga, where he himself had been a student during the 1970s, and a bastion of Shining Path ideologues ${ }^{37}$ represented another form of domination or colonization. He makes a comparison between the armed struggle carried out by Shining Path and the Spanish conquest of the Incas. When the Spaniards arrived in Peru in 1532, they aimed to evangelize and civilize the indigenous populations. For Jiménez, Shining Path also sought to "evangelize" through their own ideology. Thus, Jiménez compares the spread of the Shining Path version of Marxism to that of Catholicism (the colonizer's mission in the new continent), signaling how change and the destruction brought by violence have adversely affected Andean communities.

On first impression, Jiménez's cross could evoke the reenactment of old Andean stories in which new periods begin after a terrible cataclysm (pachakuti). ${ }^{38}$ 
Jiménez's words suggest, however, that even if this violence inaugurated a new period characterized by change and massive migrations, it failed to bring about a new order of things. Shining Path aimed to transform Peruvian society, but in Jiménez's opinion Shining Path represented a continuity, just another process of colonization or totalizing project projected on the region by outsiders.

This retablo is a subtle plea for reconsidering the humanity of the people involved in this violent period. The anthropologist Kimberly Theidon has written that the context of war reshapes the moral lives of those in communities who have family members who killed or were killed. She suggests that due to violence, people can have contradictory ideas and feelings regarding the same event. On the one hand people "could see their relatives and neighbors in the guerilla columns that attacked them, while also insisting the Senderistas were not really human at all." ${ }^{39}$ On the other hand the Shining Path ideology positioned Andean peasants as members of an amorphous mass that needed guidance and thus, neglected their identification as "real people," or runa in Quechua. ${ }^{40}$ Identified as a mass rather than as individuals or distinct communities, the peasants felt as if they were also losing their status as human beings. As Jiménez's reflections suggest, the peasants thus experienced not only the loss of their means of subsistence (represented by the cross and the crops) but also the loss of their identity and historicity as distinct peoples.

Memory and the practice of remembering are also fundamental aspects in the construction and recognition of identities. ${ }^{41}$ Retablistas-like Jiménez and his siblings - privilege the need to remember the past, especially moments of war and violence when things changed quickly and dramatically. They call for a historical awareness and sense of responsibility regarding the past. Not to forget implies not to repeat the same mistakes and the same violations of human rights.

\section{Retablos and the Truth and Reconciliation Commission}

The retablistas' desire to engage with and present the past mirrors the work of the CVR. The commission promoted the understanding that to (re)build a real democracy, Peru required a historical consciousness and a historical conscience. For instance, the cvr's public hearings (audiencias públicas) created an 
opportunity such that some victims of violence felt that their stories were heard for the first time, and that both their humanity and their citizenship could be restored. ${ }^{42}$ The CVR thus initiated many important moments in fostering a politics of reconciliation. ${ }^{43}$

Perhaps the similarity of the retablistas' and the commission's calls for a historical awareness explains, in part, the commission's decision to use a stage in the style of a retablo for the ceremony of commemoration of the victims of violence on August 29, 2003, in Ayacucho. The retablo stage was divided into two levels, with two condors placed between them, flying with their heads looking down at the commissioners, who stood on the first level, and two enormous plants of maize were set up on each side. Two doors decorated with Andean flowers, combined with the escarapela (the red-and-white insignia that symbolizes the Peruvian flag), further flanked the main box. Lerner and other CVR commissioners addressed the people of Ayacucho in the foreground, and schoolchildren sat in the background. This chorus of children sang the anthems of both the nation and the city, their voices joined by those of the commissioners and the people of Ayacucho in the central plaza.

The stage decorations changed for the evening events, long after the official symbolic ceremony with the presence of the CVR commissioners had ended. The figures of the condors remained, but other changes were made. Similar in style to the drawings of seventeenth-century indigenous chronicler Felipe Guaman Poma de Ayala (from Ayacucho), images of the sun, the moon, and the Virgin Mary decorated the upper level. The lower level remained the same and was opened for a public performance of musicians, singers, and dancers that lasted until the evening. In the central plaza, people danced, sang, and drank.

The giant retablo stage was not decorated with plaster figures but rather inhabited by living human beings who gave public speeches or performed for an audience. It became a space for a celebration of life and reconstruction. The people of Ayacucho, the commissioners, the thousands of dead, disappeared, and killed, and the victims' relatives became symbolically reunited in this new form of retablo. A retablo stage allowed for truths to be voiced, for people to claim justice, and for a region to vindicate its presence in the Peruvian nation. The stage revived participants' and spectators' memory during this night: as 
seen in the emotional expressions captured in the eyes, laughter, and weeping of the people; in the public performances of the musicians; in the speeches of the commissioners; and in the testimonies of the victims. ${ }^{44}$ A retablo united this conglomerate of human experiences, images, and feelings: not only shared violence but also the heterogeneous representations that showed Peru's diversity and commonalities simultaneously.

Such themes of celebration of diversity within a common stage of a nation-state also appear in the original smaller format retablos. For instance, in Mi Perú, Nicario Jiménez constructs different imaginary communities united within a retablo box (a metaphor for the country, the nation-state, that he called "My Peru, Fig. 3.3"). The box is filled with small scenes and images from coastal, Andean, and Amazonian markets and streets; yet not all is calm, for the figurines are also united in social protest and demands for justice for the victims of violence. In this retablo different characters occupy the scene, demanding recognition of their rights and of the porousness of Peru's ethnic, regional, and social identity boundaries. As with any retablo made in the intimacy of a workshop, the central concept, in this case "Peru," becomes imagined and reinvented through the virtuosity of an Andean artist. In Mi Perú lies a cry for people’s participation as fully recognized citizens in a double sense: first, a call for the state to recognize these artists and their art, and second, a call for the nation to celebrate its diversity and multiculturality. ${ }^{45}$

As the anthropologist and truth commissioner Carlos Iván Degregori wrote, the weak presence of the state in the provinces and the lack of integration of all the different ethnic populations into a single movement (or paradigm of national integration) have led many groups to apply different meanings to the concept of "Peru." ${ }^{46}$ Therefore, many amorphous senses of belonging, rather than a single totality, compose the idea of the "nation"-all products of human imagination associated with specific collectivities. Peru, however, remains a constant referent in these representations. The concept (Peru), like the retablos, is filled with the images, fragments, scenarios, and characters. As agents and products, retablos act not only as instruments that can transmit memory and in which different forms of memory interact, but also can serve as a metaphor for a wider idea: one that demands the constitution of a more diverse and egalitarian nation-state. 


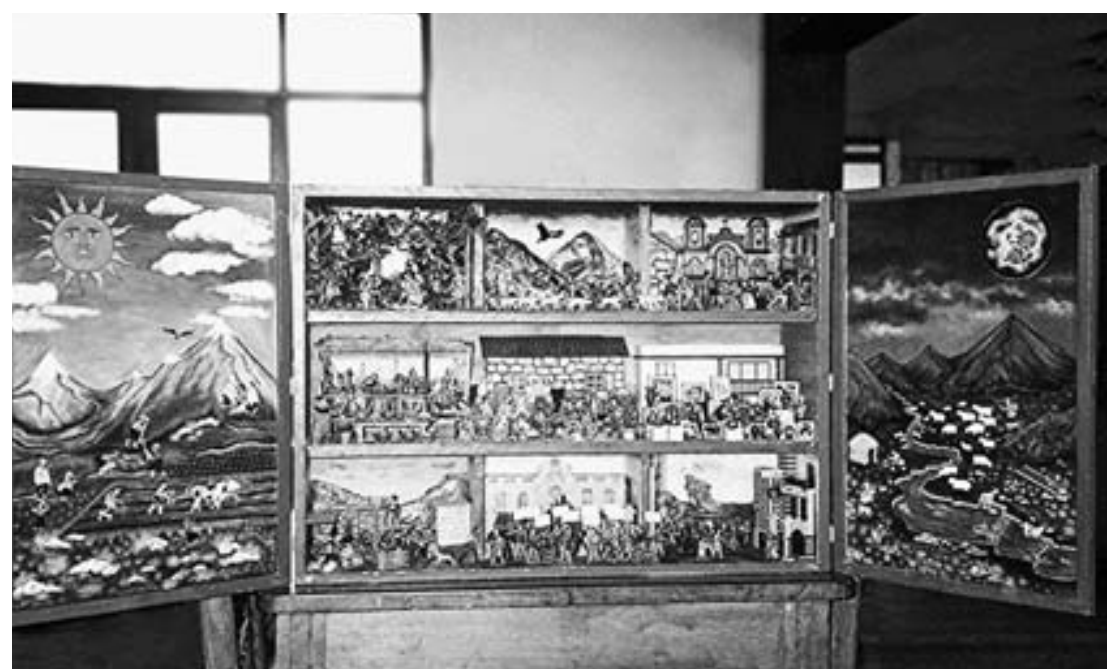

Figure 3.3. My Peru (Mi Perú), retablo by Nicario Jiménez. Photograph by author.

Perhaps it was this hope for the recognition of Peru's diversity within the singular nation, that of Peru, that the CVR commissioners chose to use the retablo stage for hosting the public presentation of their Final Report. The retablo might have been meant as a metaphor for the nation-state. Yet, despite the hoped-for national consensus about a common traumatic past, the choice of the retablo metaphor also illustrates the limits of united diversity in present-day Peru, and of an inclusive pannational remembering of the violence. The retablo stage was set up in Ayacucho, not Lima. Two events were held: the one in Lima was the official ceremony to conclude the cVR's work; the one in Ayacucho was a "symbolic ceremony." ${ }^{27}$ These two events employed different registers to speak to their different audiences: for the first, the commissioners, the president of the Republic, and government officials were all solemnly present at the Government Palace; ${ }^{48}$ for the second ceremony, the commissioners (with the president of the Republic noticeably absent) appeared in the center of a regional symbol, the retablo. The retablo, it seems, even when erected as an enormous stage for remembering a difficult national past, remains somehow "folk" art, despite such efforts to make it a national imaginary for all Peruvians. ${ }^{49}$ 


\section{Notes}

Parts of this essay draw from Ulfe, Cajones de la memoria.

1. Huamanga is the colonial name of the capital of the department of Ayacucho. The current name is Ayacucho. Many people still use the older, colonial name to distinguish the city from the department, although I use the two names interchangeably. See also Huber, Consumo, cultura e identidad en el mundo globalizado, 37.

2. These events are described in Milton, "Public Spaces for the Discussion of Past Violence," $153-156$.

3. Lerner, La rebelión de la memoria, 163.

4. See also González, Unveiling Secrets of War in the Peruvian Andes, on the tablas of Sarhua as another example of traditional artforms changing to address the political violence.

5. A 1992 exhibition catalogue described retablos as a "Peruvian artform through which 'all bloods' are made evident." See Instituto de Estudios Peruanos, El retablo ayacuchano, 3. "All bloods" in the title is a reference to the work of José María Arguedas on mestizaje.

6. Cited in Augé, Las formas del olvido, 36-38.

7. An opposing example is analyzed by Thomas Cummins, who studied queros (drinking vessels) - an Inca artform reinterpreted during the colonial period. See Cummins, Toasts with the Inca.

8. See Urbano Rojas and Macera, Santero y caminante; Mendizábal, Del sanmarkos al retablo ayacucho; and Razetto, Don Joaquín.

9. Quoted in Arguedas, Todas las sangres, 153-154.

10. The makers of Sanmarcos and other religious images and crosses were called imagineros, makers of images. Joaquín López Antay was first known as an imaginero, later as a retablista.

11. For instance, see de la Cadena, Indigenous Mestizos.

12. Contreras, Aprendizaje del capitalismo.

13. Contreras, Maestros, mistis y campesinos en el Perú rural Siglo XX. See also Glave and Urrutia, "Radicalismo político en elites regionales."

14. Contreras, Maestros, mistis y campesinos en el Perú rural del Siglo XX.

15. Drinot, The Allure of Labor.

16. Ansión, Anhelos y sinsabores, and Lauer, Crítica de la artesanía.

17. Ulfe, Cajones de la memoria, 69-74.

18. García Canclini, Hybrid Cultures.

19. Castrillón, “¿Arte popular o artesanía?”

20. Castrillón, “¿Arte popular o artesanía?," 16-17.

21. On migrations from the countryside to the coast, especially to Lima, see Matos Mar, Desborde popular y crisis del Estado.

22. Gell, Art and Agency. 
23. Most of this artwork is done by men, even though there are some female retablo makers, like Eleudora Jiménez (daughter of Florentino Jiménez), and female family members may help in the production.

24. Artisans can now win three national awards: the Gran Premio Nacional Amautas de la Artesanía Peruana (The Great National Amautas Peruvian Crafts Prize), Grandes Maestros de la Artesanía Peruana (Great Masters of Peruvian Crafts), and Premio Nacional de Artesanías Inti Raymi (National Crafts Inti Raymi Prize). Ulfe, Cajones de la memoria, 71-74.

25. For an excellent example, see Gonzáles Carré, Urrutia, and Lévano, Ayacucho. A section of this book is dedicated to popular arts, including retablos. Most of the illustrations show Nativity retablos, also called retablos costumbristas (retablos that depict traditional customs). The introduction only briefly mentions the period of violence, and no violence appears in the book's illustrations.

26. Some art depicting escalating violence in the highlands did, however, appear in 1980 s art contests meant to represent campesino life and customs. However, none of these pieces won a prize. See Milton's chapter here.

27. For example, see José Luis Rénique, La batalla por Puno, 20.

28. Quijano states that "coloniality of power" should be understood in relation to the development of capitalism, whereby race and the division of labor became structurally linked. Quijano, "Colonialidad del poder."

29. For example, Andean peoples privilege oral transmission over written texts. "This does not mean, as some books on orality suggest, that sound becomes the privileged vehicle for information, but rather that encoding is dispersed over a variety of actions and locations, which include ritual, theatre, music, pilgrimages, artefacts, narratives and all the ways in which the earth itself is perceived as patterned with lines and significant points. These patternings add up to a multitude of 'graphies,' of 'writings' available to be 'read,' and in which the native cultural 'archive' is stored." Rowe and Schelling, Memory and Modernity, 52-53.

30. The choice by the CVR to use the retablo as a stage for the symbolic ceremony of the CVR's Final Report, of course, show that there are efforts to incorporate other forms of memory work into national debates. Other attempts include the Instituto de Estudios Peruanos's project to preserve and digitalize Edilberto Jiménez's work, including his retablos. See http://archivo.iep.pe/cid/galeria-cid/universos-memoria.php, accessed July 2, 2013 .

31. Manrique, El Tiempo del miedo, 41-64.

32. The 1990s were characterized as the decade of the "antipolitics." This meant the loss of trust in political parties, the approval of Fujimori's "strong hand" in government (1990-2000), including military repression, deaths, disappearances, etc. and acceptance of corruption as "part of our lives." This paradigm, however, changed in 
September 2000, when a member of Congress released a video of Fujimori's security advisor Vladimiro Montesinos bribing a congressman to obtain his support for the ruling political party. See Degregori, La década de la antipolítica.

33. Rowe and Schelling, Memory and Modernity, 37.

34. Claudio Jiménez brought the piece of log from Ayacucho, reflecting his belief that an artist needs to innovate. In his words, "an artist has to live like this not to stay [behind]. I am like that; I travel. I look for novelties. An artist is nourished from that. We [artists] share these feelings." Author’s interview with Jiménez, Zárate, July 23, 2001.

35. Author's interview with Jiménez.

36. Author's interview with Jiménez.

37. Degregori, El surgimiento de Sendero Luminoso.

38. A cataclysm usually causes the end of a temporal period (or cycle), which also signals the beginning of a new period. In Ayacucho, people tend to speak of the period of violence as a big cataclysm. See Allen, The Hold Life Has, 46-47.

39. Theidon, Intimate Enemies, 214.

40. Runa (plural runakuna) means "human being," or according to Allen, a "culturally Andean indigenous person." Allen, The Hold Life Has, 7-8, 276.

41. Connerton, How Societies Remember.

42. Ulfe, "Reflexiones sobre los usos del testimonio en la esfera pública peruana," 208-212.

43. Unfortunately, most of the recommendations made by the CVR are still pending. One recommendation was for reparation of victims. Ministerial Resolution 373-2006PCM created the Reparations Council (Consejo de Reparaciones) to organize the Victims Registry (Registro Único de Víctimas), a national census of victims. Yet work has been slow. For instance, in 2009 its budget was cut, and none of the activities programmed to economically and symbolically repair victims of violence could be carried out. Nevertheless, the Consejo de Reparaciones continued with the help of civil society and local organizations to build the national census of victims.

44. Description of these events in Ayacucho on August 29, 2003, come from conversations with Cynthia Milton. See also Milton, "At the Edge of the Peruvian Truth Commission."

45. Telephone conversation with Nicario Jiménez, May 6, 2002. Also see Ulfe, Cajones de la memoria, 284-288.

46. Degregori, "Identidad étnica, movimientos sociales y participación política en el Perú," 127.

47. On different descriptions of events and how they were labeled, see www.cverdad .org.pe/paginao1.php, accessed June 2, 2013.

48. Given that this event was televised, it might have been difficult to stage the ceremony on a giant retablo. 
49. Subsequent uses of the retablo as a stage to host events supports this interpretation of the continued association of the retablo with "folk" art: in 2004 and 2011 retablo stages were set up for "the dances of Peru," as part of annual national celebrations (fiestas patrias). See the website of Leydy Castro García, http://peruinfoperiodismo.wordpress .com/2011/o8/o7/el-retablo-de-los-suenos, accessed July 2, 2013, and Radio Programs of Peru, www.rpp.com.pe/2011-07-12-trescientos-artistas-danzaran-en-megaretablo-por -fiestas-patrias-noticia_384034.html, accessed July 2, 2013. 

PART TWO / TELLING STORIES OF POLITICAL VIOLENCE 

VIOLENCE, GUILT, AND REPETITION / ALONSO CUETO'S NOVEL LA HORA AZUL

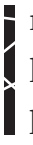
$\mathrm{n}$ recent years, Peruvian literature has worked intensely to represent the political violence of the last decades of the twentieth century. Some novels have known great success: in 2006, The Blue Hour (La hora azul), by Alonso Cueto, and Red April (Abril rojo), by Santiago Roncagliolo, both won the prestigious Spanish-language awards Anagrama and Alfaguara. At the same time, the Peruvian-American bilingual author Daniel Alarcón published the award-winning War by Candlelight (2006) and Lost City Radio (2007). In 2010, Peru's most fêted and well-known author, Mario Vargas Llosa, some of whose writing has addressed the theme of political violence, won the Nobel Prize in Literature for his life's work. ${ }^{1}$ These authors have placed Peruvian literature, and the theme of Peru's internal war, in the forefront of the international literary scene.

Peruvian literature is playing a fundamental role in the ways that Peruvian culture is attending to the past political violence in the present day. Beyond the international recognition of the literary merit of these novels, these works have had an impact on Peruvian memory debates by making conceivable what happened, often taking as their point of departure some of the findings of the Peruvian Truth and Reconciliation Commission's Final Report. Indeed, the commission may have greater impact in cultural domains than in any other social or political sphere, and its conclusions are entering into the national imaginary via artistic texts. The focus in this chapter is on the novel The Blue Hour by Alonso Cueto, a novel that goes beyond just criticizing the role of the armed forces in the internal conflict to show us how the ongoing effects of the political violence are imagined within contemporary memory questions, in particular with the 
role played by middle- and upper-class Limeño society in the conflict and their subsequent responsibility.

With an epigraph from Javier Cercas ("at best, one is not only responsible for what one does, but also for what one sees or reads or hears"), La hora azul places before the reader several questions that invite response: Is guilt something that is socially inherited? Are new generations in some way also participants in atrocities committed in the past? What responsibility does the present generation have toward history? In postwar Germany, Hannah Arendt reflected on the subject of inherited guilt and proposed the need for subsequent generations to acknowledge what had taken place without the future citizenry necessarily identifying itself as "guilty." In her opinion, indignation was an emotion more likely than guilt to render justice. ${ }^{2}$

In recent years, a sector of the Peruvian middle and upper classes has been building an exculpatory narrative of political violence. "We did not know, we did not want to know" have become commonplace phrases and can be extended to the behavior of the state itself, which has come to treat the violence as an exclusively military problem. "Not knowing" and "not hearing" are thus phrases that reveal what has come to be called the "differential impact" of political violence. In fact, the most devastating finding of the Truth and Reconciliation Commission was not that more than 69,0oo people had died but the assertion that "no one" had known of more than half of these deaths. ${ }^{3}$ Neither the state nor the most respected human rights organizations nor civil society itself had estimated that the final figure would come to double previous official statistics: "these are people who suffered a tragedy, and the country-not only in its official dimensions but also in its social - simply did not notice that they had died or disappeared. This is more or less to say that these Peruvians were nonexistent for the nation long before they had, in reality, ceased to exist."4 This invisibility is in keeping with the way the Peruvian nation has historically been constructed and imagined. Successive governments did not engage this population and thus did not know what happened within the nation's boundaries.

In this chapter I argue that Alonso Cueto's La hora azul aims to reveal the least well-known dimension of the political violence: the guilt of Peruvian citizens, and how this guilt might be constructive in building a different national 
consciousness, one such that Peruvians, regardless of class, know and want to know about their fellow citizens and territory.

I don't carry the guilt of my father.

Of course you do, or maybe you have part of the guilt, see?

But why?

We all carry the guilt of our parents, and of our children too.

I don't see why.

Just because. $^{5}$

The novel recounts the story of Adrián Ormache, a prominent lawyer in Lima who, after his mother's death, begins to discover an undeniably shameful family history. The novel narrates how the protagonist goes about confronting a truth that is more awful at every turn but that he, far from evading or denying, decides to face through to is ultimate consequences. By means of this narrative structure of revelations of a family past that resonate into the present day, the author asserts that knowledge of the truth (or here revelations) can transform subjectivities and in this way initiate a process of national reconciliation. In a first instance, the "truth" Ormache discovers has to do with the fact that his father, a high-ranking soldier in the zone of violence, was a torturer and a rapist of peasant women. In a second instance, he discovers that one of these women is alive and that he likely has a half-brother.

La hora azul follows the format of a detective story: the novel is, in effect, an allegory intended to name the country's need to uncover a hidden truth. For this reason, from its first pages La hora azul is eager to give an account of the nation's fractures and emphasizes the frivolity of the Peruvian upper class. The story begins with Ormache describing his appearance as if in a magazine for the "jet set." Smiling, triumphant, sure of himself, Ormache is presented as a person who is confident that he has no personal problems. He feels proud to count among his friends Fernando Belaúnde, Lourdes Flores, and other politicians of the Peruvian right. "I liked having a well-located house, a wife who was agreeable and affectionate and a good hostess, daughters who were well behaved and accomplished at school. I liked, I am not ashamed to say, to be well-dressed." ${ }^{\prime 2}$ The protagonist is portrayed as knowledgeable about Peruvian reality - a knowledge that is never 
questioned and does not pose any destabilizing elements, and that the character handles comfortably alone within his social circle. It is precisely at this kind of "knowledge" that the novelist directs his critical gaze in order to question the official versions of the internal armed conflict: "and so for many years I lived with the certainty that my father would have been in Ayacucho, fighting Shining Path terrorists, and that he had done something to defend our nation."7

Nevertheless, this knowledge - a heroic narrative of defending the nation - is challenged by the discovery that the military committed human rights abuses. In particular, Ormache discovers his own father's involvement in these abuses: "the women, he fucked, and sometimes afterwards he gave them to the troops for them to fuck, and then after they shot them; those things he did." 8

In this way, the novel places before its readers two conflicting discourses that claim to account for political violence in Peru. The first discourse, a nationalistic one, advances the argument that the state and the armed forces acted to "defend" the population and in the process might have committed "excesses." The second discourse presents soldiers and Senderistas as both responsible for the terror and illegal acts of violence.

The subject of rape is central to this novel: it is presented as a strategy of war, as a generalized practice that demonstrates the way the state interacted with its population during the armed conflict. ${ }^{9}$ In effect, by making rape visible, La hora azul narrates one of the most hidden subjects of the political violence; not the story of the actions of Shining Path (which are largely known by all Peruvians) but rather that of the armed forces (less well known among the Peruvian middle and upper classes).

The officials tossed the bodies of the dead in a dump so that the pigs would eat them and their families could not recognize them. One time, three soldiers killed a baby in front of his mother and then raped her next to her child's body. Don't go on telling me this, he said. Fine, but actually all of this was in response to what had been done by Shining Path who burned their prisoners alive and hung notices on the charred corpses. One very widespread Senderista practice was to execute the mayors of villages in front of their wives and children. They killed them in front of them and then forced 
them to celebrate. They hung the corpses of babies in trees. All this they told me. ${ }^{10}$

La hora azul portrays soldiers as trained to commit criminal acts and depicts the military as depraved. The torturers who appear in this novel (Charo Osorio and Guayo Martínez) are pathetic figures, with no understanding of the complexities of what was happening in their country. The soldiers' brutal actions reproduce the vices of this poorly constituted nation-state, where racialized geography feeds human rights abuses committed by coastal Peruvians (mestizo) against highland (largely of indigenous descent) Peruvians.

Clearly, if La hora azul foregrounds the subject of the ethical deprivations of "the forces of order," it does so in order to engage contemporary debates over endemic human rights violations by the armed forces. The novel presents human rights abuses not simply as acts of individuals (and thus "excesses") but as the result of a generalized practice within a calculated strategy of war. Thus, while this novel is written against the society as a whole that allowed the violations, it specifically targets the military institution as responsible for harming Peruvians rather than defending them and for attempting to hide this violence.

At the heart of the novel is the relationship between the lawyer Adrián Ormache and Miriam, a woman his father raped, who was able to escape one night from the barracks where she was being held prisoner. The author tells us very little about Miriam: we know that she was originally from Luricocha, in Ayacucho, that Shining Path killed her older brother, and that shortly thereafter the rest of her family also died in a confrontation between soldiers and Senderistas. Terrorized by what had happened - the deaths of her family, rape, assaults against her community-Miriam managed to migrate to Lima, where with the help of an uncle she gave birth to Miguel and began working in a hair salon. We never learn her last name.

The novel narrates how Adrián Ormache meets Miriam and enters into an intense relationship with her. He becomes acquainted with Miriam after he has learned the truth about his father's actions in the highlands. In meeting Miriam, Adrián confronts an often-denied dimension of his country: that of social hierarchies, inequality, and racism. Throughout the novel, Adrián grapples with 
his class prejudices and his tastes. For example, he discovers the northern zone of the city where internal refugees have migrated to escape the war ("for me, all this was a lunar landscape; I never would have thought I'd be there"). ${ }^{11}$ Though he cannot stop aestheticizing the migrant neighborhoods, he nevertheless snobbishly mocks criollo or popular culture.

Similarly, Adrián's relationship with Miriam is one filled with attraction and repulsion. It seems that the more involved with her he becomes - to the point of obsession - the greater his guilt and torment, leading to his ultimate rejection of her. Yet, on her death, his obsession suddenly dissipates. He returns quickly to earlier social hierarchies and prejudices. Initially, Miriam seems to him "the most beautiful woman in the world," 12 but once she dies he changes his mind: "But, aside from her eyes, I now think that she wasn't a pretty woman. She was rather somewhat unpleasant."13

Why this change in perception of her beauty? It seems that Adrián's sense of guilt is what makes him initially attracted to Miriam. His guilt temporarily suspends his normal tastes, thus altering his vision so as to see her as attractive. This guilt draws him closer to her. Yet the Miriam he sees is his imagined vision of her-someone who serves as a foil to his machinations rather than a real person. This is a crucial point to note, since the novel's end draws a parallel between Adrián's imaginings and those of the nation-state.

Yet guilt for his father's actions does not fully explain Adrián's attraction to Miriam. Both men fell in love with Miriam. In the case of Adrián's father, according to Adrian's version of events, he detained Miriam in order to prevent her being raped by other soldiers. Even though Adrián seems to reject his father's actions, the author nevertheless draws a paternalistic parallel between father and son. By falling in love with Miriam, the son repeats something of the father's act: he sexually dominates Miriam while legitimating such domination as protective love. While it is Adrián's brother, Rubén (a lascivious criollo), who looks physically most like their father, it is Adrián who reproduces his paternal inheritance by placing himself in the same position of power as his father. After the death of the father the position of power is empty, and so the novel narrates how a new subject prepares himself to occupy it. What does not change is a certain masculine movement: the father abducts Miriam, then Adrián harasses 
her. In both cases, Miriam always appears as an object on which the desire of the other is imposed.

The relationship that is established in the novel between voice and power is also noteworthy. In fact, the whole novel is told from a first person point of view, with the protagonist finally declaring his fantasy of being a writer. In effect, the lawyer Adrián Ormache not only speaks all the time but also seizes on literary writing, which he begins to idealize almost vulgarly. In other words, the narrator becomes very conscious that his power is also a linguistic one. The vehement sense of the necessity of "knowing" that spurs nearly all of his actions presupposes that truth can be discerned objectively and, from there, that the aesthetic form is, in itself and for itself, a site of "truth." Ultimately, his identification with language takes on such magnitude that he does not understand Miriam's silence: "If you're not going to speak to me, I don't know why you came-I said to her. It would have been better for you to have stayed at home. Next time, send me another girl who'll at least talk to me, not a mute like you."14

Adrián does not ask himself why Miriam has remained mute or about her choice to keep silent. Is Adrián simply just a new torturer, replacing the previous generation, who attempts to access the voice of his victim? This explanation might seem excessive, but it is consistent with the fact that the novel deals with the character's constant effort to handle his paternal inheritance: "I could not free myself from him," Adrián says, aware that his destiny is still possessed by an inheritance that is very difficult to manage. ${ }^{15}$ In effect, the father goes on living as a ghost who makes his presence felt throughout the novel.

The novel places Miriam and her son, Miguel, in a very different position relative to language: they do not speak, or they speak little, and they are represented to readers with a buffer of silence around them. To a certain extent, the silence of both is their answer, or their testimony, regarding everything that has happened. Miriam herself says this at one point: "Because when Miguel grows, his silence will grow with him. That's what I always think."16

Thus the issue is not only that the subaltern does not speak in this novel but additionally that "its not-speaking accumulates" and becomes the signifier of a still-active past and of a present full of unresolved wounds. ${ }^{17}$ The representation of power goes hand in hand with that of the subaltern world, which is defined 
as one that has interiorized its own colonization and that has been deprived of all voice. When the subaltern does speak, the words seem all the more powerful:

I hated your father so much, I tell you. I could have killed your father if I had had the chance because he deceived me so much and abused me, in that room. I hated him so much: because of them, because of the soldiers, because of the morocos, I lost my family. I could not see my family, I could not reach them; they died; they died without me. And I hated your father so much; but now I no longer hate him; now I almost love him. ${ }^{18}$

I hated him but then I loved him; I loved him very much; and, I had to leave him but I love him still. Your father was the worst man, but also the best man to me. He kept me locked up but he also made it so that they would not kill me. ${ }^{19}$

The simultaneous emotions of hate and love are not solely an instance of "Stockholm syndrome" but are an attempt by the author to create a representation in which wounds can heal themselves and to produce the site on which society can build national reconciliation. The novel strives anxiously for that result-possible national reconciliation-but ultimately does not fully reach it. In this sense, the author of La hora azul seems to propose that the condition under which reconciliation might occur is when both abuser and abused end up falling in love with each other. This dynamic is projected through to the end of the novel, when the subaltern (in this case her son, Miguel) is finally able to say something. Curiously, Miguel renders thanks to Adrián. In the final dialogue between Adrián and Miguel, a kind of conciliation takes place. Adrián says:

The other day I went to an academy near your house-I told him. They have some preparatory classes there for the University of Engineering. They teach you math and prepare you for the exam. Now, when we go back we'll pass by there to see if you can start.

I don't believe he answered me. But when I turned, Miguel was looking at me. He looked straight at me for the first time, like I think he had never done before. So I saw the brown reflection of the eyes, the eyes [of his mother] that I had seen in the bed of that hospital. But unlike that day, when I had turned away and had left her there to die, [this time] I stayed sitting next to him, a long while, in silence. 
I wanted to tell you something-he [Miguel] said.

What?

He looked at the horizon. The winter was stretching itself over the sea and was lost in the long arm of La Punta.

I wanted to thank you-he said. Thank you, that's all. ${ }^{20}$

Commenting on these paragraphs, Juan Carlos Ubilluz argues that this ending sets up charity - a reciprocal pact whereby the recipient (Miguel) thanks the benefactor (Adrián) for his generosity-as the beginning of national reconciliation. ${ }^{21}$ Yet the pact is uneven: the fact that the victim "thanks" a representative of power reinforces the vertical communication between one social sector and another. It could be further argued that such charitable acts promote complacency toward inherited guilt. After all, Adrián begins to feel better about everything that he has done in the past (and perhaps even his father's acts) because he will have helped Miguel go to university. This act of "charity" allows Adrián to return to his home and to his life as it was before he knew the "truth," a little more content.

Whether this charity promotes reconciliation is not clear. First, we do not know whether or not Miguel accepts Adrián's offer to help with his education. Miguel seems hesitant, and we do not know his life plans. With this narrative trick of an unresolved conclusion, the author leaves the reader not knowing how the relationship will continue or what will happen to Miguel in the future. Importantly, we never find out if Miguel is indeed Adrián's half-brother.

The very possibility of charity as leading to absolution, or at least to a less guilty conscience, also remains unresolved in this novel. Much of the novel illustrates the way Adrián attempts to become more aware of and sensitive to social inequalities. Yet ultimately he remains stuck in his racial stereotypes and social hierarchy. Charity, in Adrián's view, allows him to envision himself as having changed, without undergoing any radical transformation that would alter his dominant position. "In front of the red light [at the intersection] was gathered the typical group of beggars. Usually, I barely turned around. But that night I fixed on a girl with braids. I gave her a coin." ${ }^{22}$

Charity might only serve to exorcise his guilt. Ultimately, it just reinforces social hierarchies. Charity is a gesture that strengthens only the holder of power and never that of the recipient, who remains dependent on the benefactor. In 
this novel, charity is the pathetic gesture of a character who does not know what else he can do in a society as degraded as Peru's.

The author presents no alternative and no path by which Adrían could do something better, could change. In effect, while Adrián has done much to arrive at the truth, and he has not been afraid to confront this truth, he falls short of moving beyond it. He is willing to give a coin to a beggar girl but does nothing to address the roots of poverty. While his attitude about beggars (or this specific beggar) might have changed, he does not question the social inequalities that allow for him to be a well-dressed man, with well-mannered daughters and wellplaced friends, yet leave Miguel, his possible mestizo half-brother, dependent on him for his education.

In this, the novel concludes by illustrating the lack of individual or societal transformation. Despite his seemingly good intentions, Adrián is portrayed as someone who cannot stop exercising power over others. Only his means of exercising power have changed: formerly a rapist's son, he has become a lover; formerly an indifferent passerby, he is now a charitable patron. Thus, La hora azul projects the continued domination of white male power: it is not coincidental that the novel ends with two men conversing (an adult man, Adrían, and a boy, Miguel) and almost negotiating between them a possible national reconciliation, one that retains a strong tutelary structure.

Why are you helping me so much? [asks Miguel]

I added something like how in Peru there were many social and economic differences and that those of us who were more fortunate had a duty toward those who do not have so much. It seemed to me that someone was dictating to me what I ought to say. ${ }^{23}$

The novel ends with an image in which the restoration of the linkages between Peruvians comes about through an option with very little social weight or will: charity. Power in contemporary Peru may display more "solidarity" and be more "humane," yet charity as a solution to inequalities or a means toward reconciliation remains unconvincing. Adrián repeats something he thinks he "ought to say," not necessarily something he believes. The author thus draws a parallel between the social obligation to charity and national reconciliation. 
Obviously I'm not going to do anything to remedy the injustice so threaded through reality, I can do nothing, I'm not going to help them, nor, perhaps, does it interest me. And yet to have known about so many deaths and tortures and rapes now saddens me so much, and also shames me a little. I don't know why. I won't forget them. Even though I only tell it to myself, and to her. ${ }^{24}$

Does the character free himself from guilt at the end of the novel? We do not know. But what is clear is that the text evades the possibility of a more just society and destroys any impulse that might lead to it. In this sense, Miriam's suicide ends up being an expedient and effective way to evade the possibility of union between two personages of such gaping social differences. It is clear that the novel cannot imagine this possibility. That is, had she not died, the relationship with Miriam would have confronted the narrator with aesthetic and symbolic challenges of greater scope: how to make readers believe possible a loving relationship between these distant social classes, let alone between victim and perpetrator. Peruvian society faces a similar challenge: how to imagine a national community without classist or racist hierarchies of vertical and tutelary relationships. Adrián chooses individual resignation-he cannot transform society, so he does not try; similarly, national reconciliation does not involve comprehensive social transformation but remains an abstraction, ${ }^{25}$ as charity does in this novel. Rather than a sign of national reconciliation, charity here remains a means to keep others in subaltern positions. If at any moment the utopian possibility was offered in the relationship between Adrián and Miriam, that of equality and without domination, the novel's end destroys this possibility: in the final conversation between Adrián and Miguel, they both become aware of the intractability of their predetermined positions in society.

In the end, La hora azul portrays a breach-immense and insurmountablethat still cannot be overcome in Peru. Why does the lawyer Adrián Ormache continuously despair before the muteness of the two subaltern characters? In a society like Peru's and in a literature in permanent crisis such as ours (I refer to its excessively Lima-centric character), continuing to explore this relationship between subaltern and elite voices, guilt, and responsibility for the past is of crucial importance. 


\section{Notes}

I am grateful to the Intercambio Cultural Alemán-Latinoamericano for their support in the writing of this chapter. Thanks also to Alejandro Grimson for a long conversation in Buenos Aires. An earlier version of this chapter appears in Ubilluz, Vich, and Hibbett, Contra el sueño de los justos. This text and all citations were translated by Kate SaundersHastings and Cynthia E. Milton.

1. For instance, La historia de Mayta (The Real Life of Alejandro Mayta, 1984), and Lituma en los Andes (Death in the Andes, 1993).

2. Schapp, "Guilty Subjects and Political Responsibility."

3. Lerner, La rebelión de la memoria, 147.

4. Mirko Lauer, "La desaparición de la desaparición,” La República, June 19, 2003.

5. Cueto, La hora azul, 149.

6. Cueto, La hora azul, 17.

7. Cueto, La hora azul, 26.

8. Cueto, La hora azul, 37.

9. The matter of the rape of women by soldiers is the most striking example of institutional policies systematically situated outside the law. This practice was so common that it has been affirmed that "where there were soldiers there were rapes" and that there was essentially never any punishment. It has been found that the majority of rapes took place within at least forty military bases. See Theidon, Entre prójimos, 120, and "Gender in Transition," 471. On this subject, see CVR, Informe Final, vol. 8. In the literary tradition, rape is also a metaphor for postcolonial identity, that of colonial power over indigenous America.

10. Cueto, La hora azul, 88.

11. Cueto, La hora azul, 152.

12. Cueto, La hora azul, 218

13. Cueto, La hora azul, 239.

14. Cueto, La hora azul, 248.

15. Cueto, La hora azul, 25.

16. Cueto, La hora azul, 251.

17. The topic has been widely debated since Gayatri Spivak's essay “Can the Subaltern Speak?"

18. Cueto, La hora azul, 219.

19. Cueto, La hora azul, 254.

20. Cueto, La hora azul, 303 .

21. Personal communication with Juan Carlos Ubilluz, October 2008.

22. Cueto, La hora azul, 258.

23. Cueto, La hora azul, 287.

24. Cueto, La hora azul, 274.

25. See Jameson, "The Politics of Utopia." 
CHAPTER FIVE / LUiS ROSSELL, ALFREDO VILLAR,

AND JESÚS COSSIO

RUPAY / (HI)STORIES OF POLITICAL VIOLENCE

IN PERU, $1980-1984$

$\mathrm{n}$ the artistic tradition of Art Spiegelman, Joe Sacco, and Chester Brown, a collective of Peruvian artists - Luis Rossell, Alfredo Villar, and Jesús Cossiopublished the graphic novel Rupay: Historias de la violencia política en Perú 1980-1984 (Heat: (Hi)stories of political violence in Peru, 1980-1984). ${ }^{1}$ The authors play with the ambiguity of the term historia, which in Spanish means both "history" as a narrative of past events and "story" as a fictional tale. Using the format of a "comic" (a term they prefer to "graphic novel"), the authors present, in a series of nine vignettes, emblematic cases from the early years of the internal conflict included in the Final Report of the Truth and Reconciliation Commission, from the initial Shining Path act of burning the voting boxes in Chuschi to the military's murder of the residents of Putis. The section reproduced here, "Uchuraccay," recounts the case of the murder of eight journalists and one guide in 1983 in the small hamlet of Uchuraccay (Ayacucho). The authors combine many sources - newspaper clippings, findings from government-mandated commissions, testimonies, rumors, and other artists' portrayals of events (including a Sarhua tabla, depicting on a painted board the special division of the national police, the sinchis) - to try to piece together one of the mysteries of the political conflict: who really killed the journalists and their guide, and why? Through their métier as comic artists, the makers of Rupay reveal the intricacies of this event, how it unfolded in the media and public imagination, and what the legacies of this massacre are, not just for the families of the murdered victims but also for the residents of Uchuraccay. In the wake of the massacre, some residents 
of Uchuraccay were accused and sentenced to prison, others were killed in subsequent Shining Path and military attacks, survivors deserted the hamlet and faced a racist backlash because they were from Uchuraccay when it became synonymous in national media with savagery. The artists bring to light inconsistencies, "hidden" facts, and testimonies in a text that is not merely a recounting of the past but is in itself a document of how some Peruvians are attempting to figure out and work through this past. From the subtle detail of a Peruvian flag with the color red (later picked up in flowing blood and in Shining Path's flag, though not colored here in this black-and-white reproduction) to the insertion of photographs and newspaper clippings from the time, this comic helps us to see the complexities of this tragedy as extending beyond the juxtaposition of "Deep Peru" (Perú profundo) - traditional, backward, outside modernity—with the rest of Peru, an unfortunate explanatory dichotomy that emerged out of the Vargas Llosa commission's investigation into the initial massacre. ${ }^{2}$ The historias in Rupay, taken as a whole, provide a lucid, stark, and moving account of Peru's civil war. 

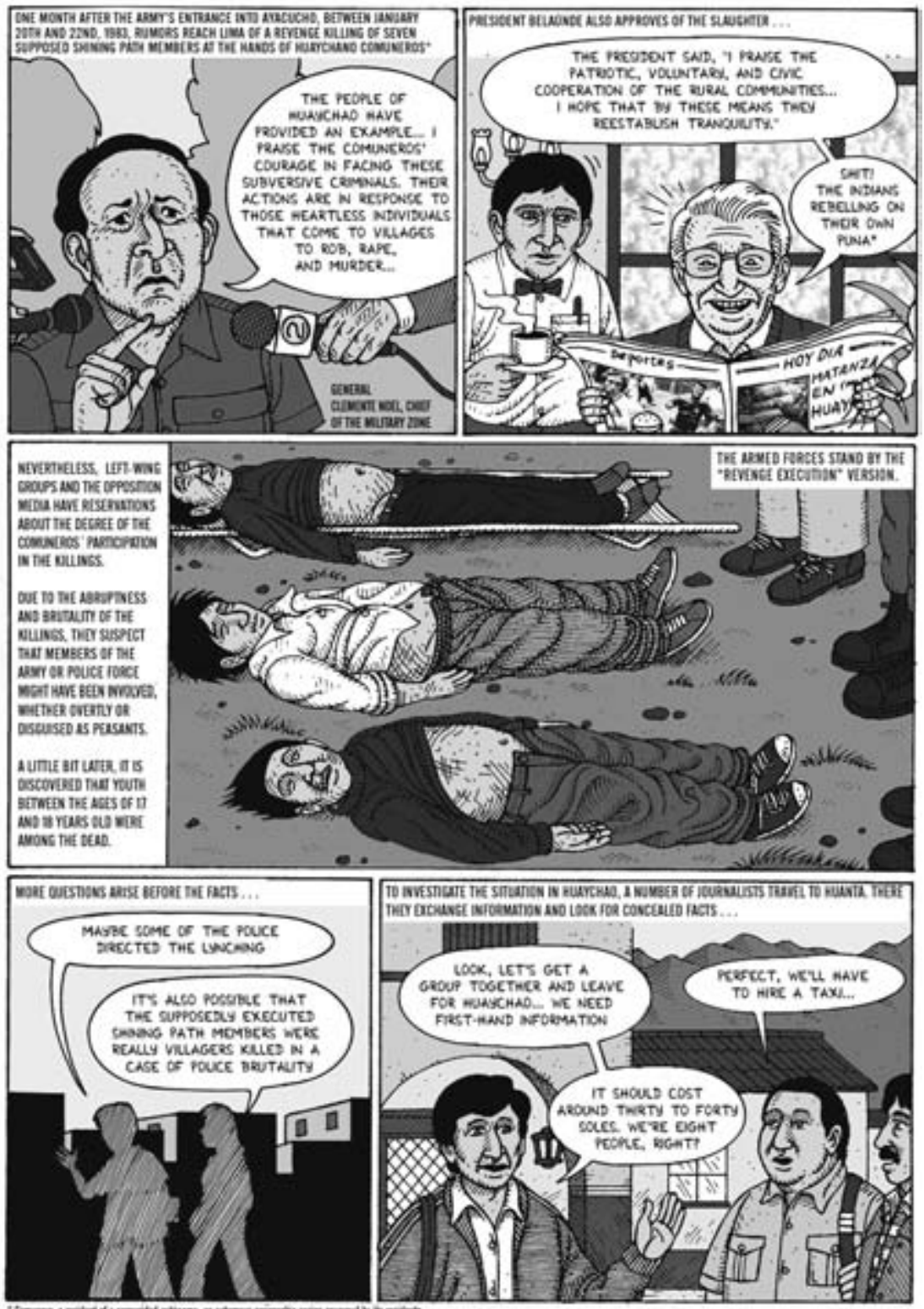

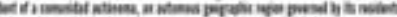

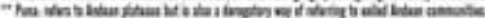



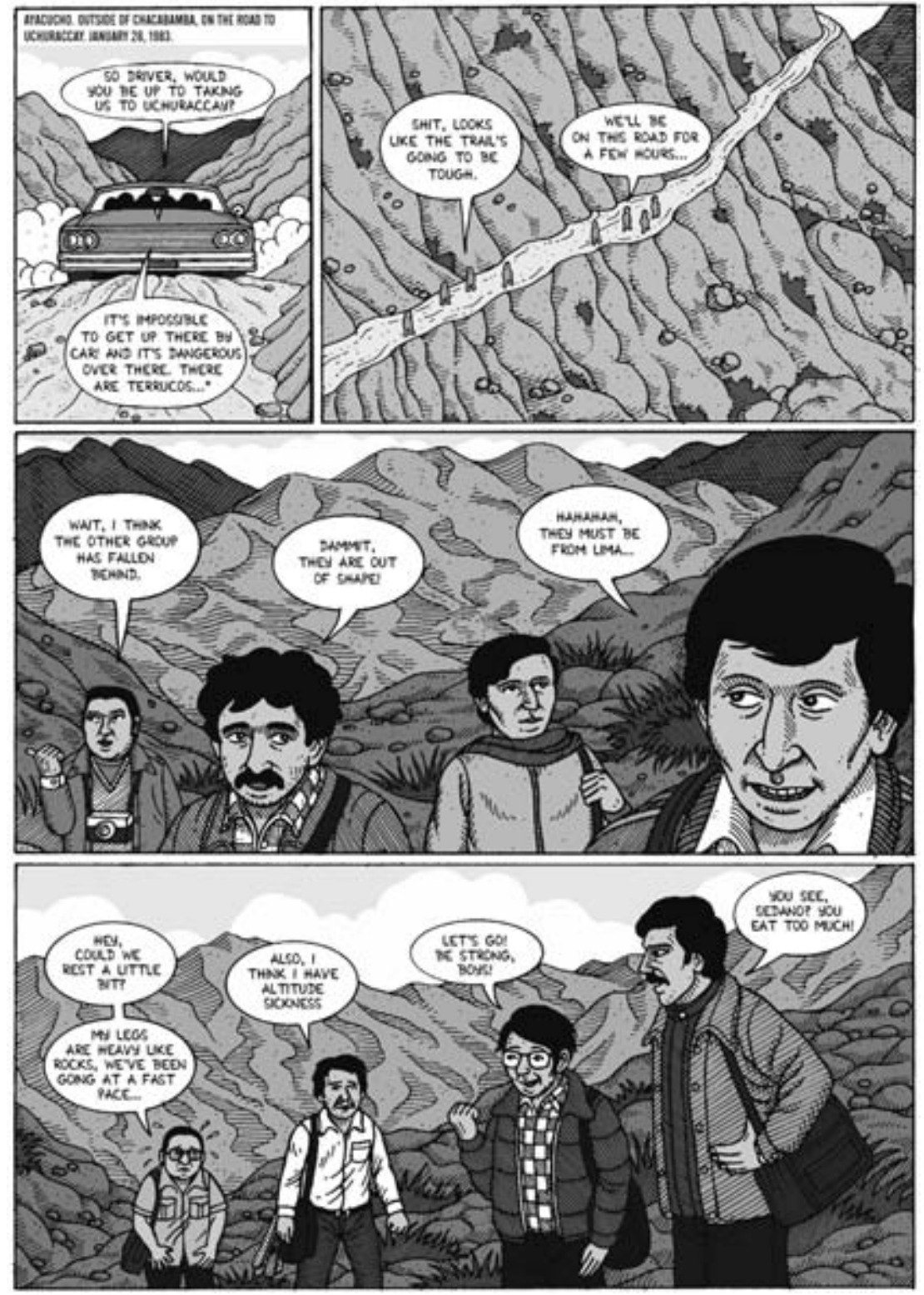

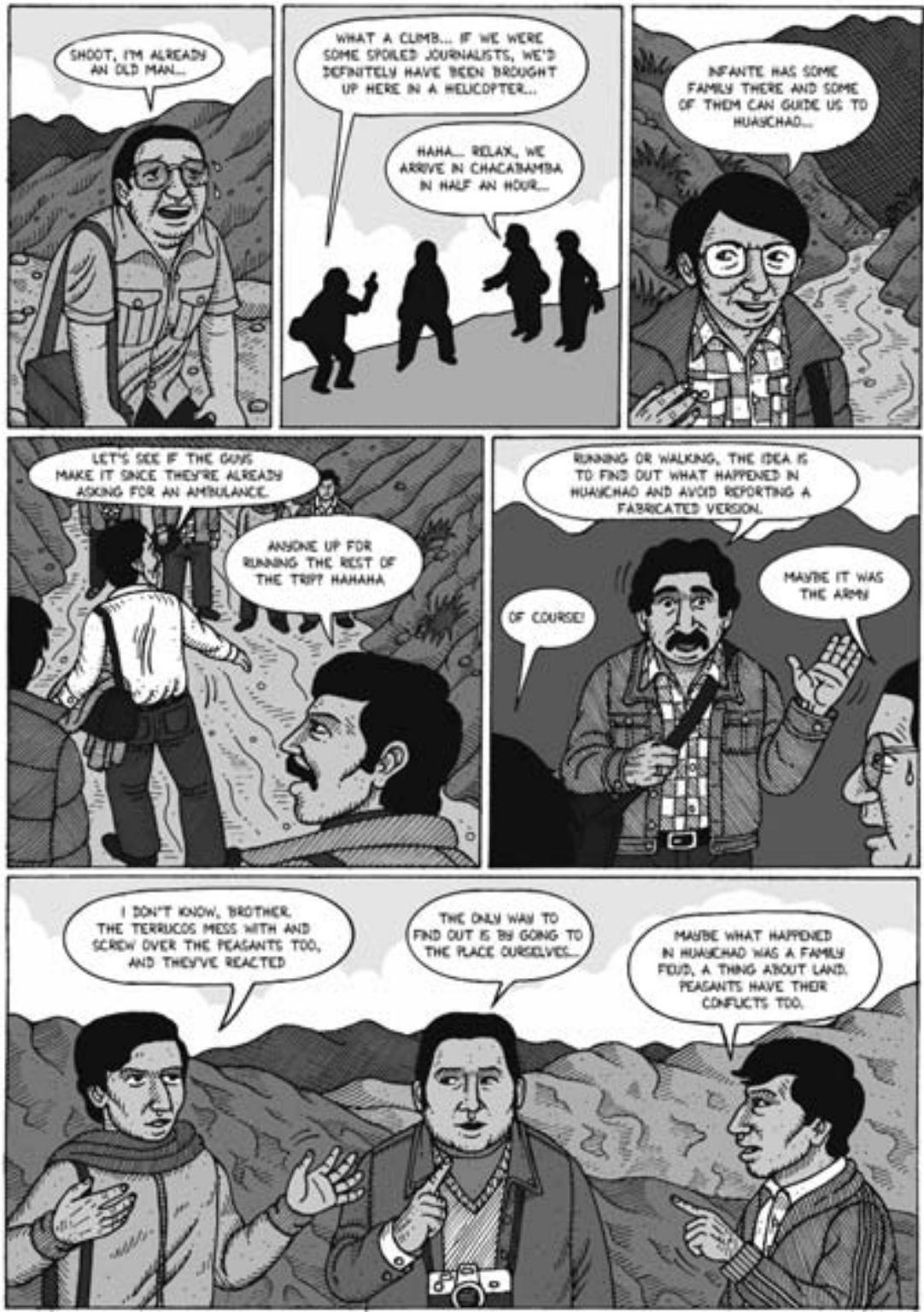

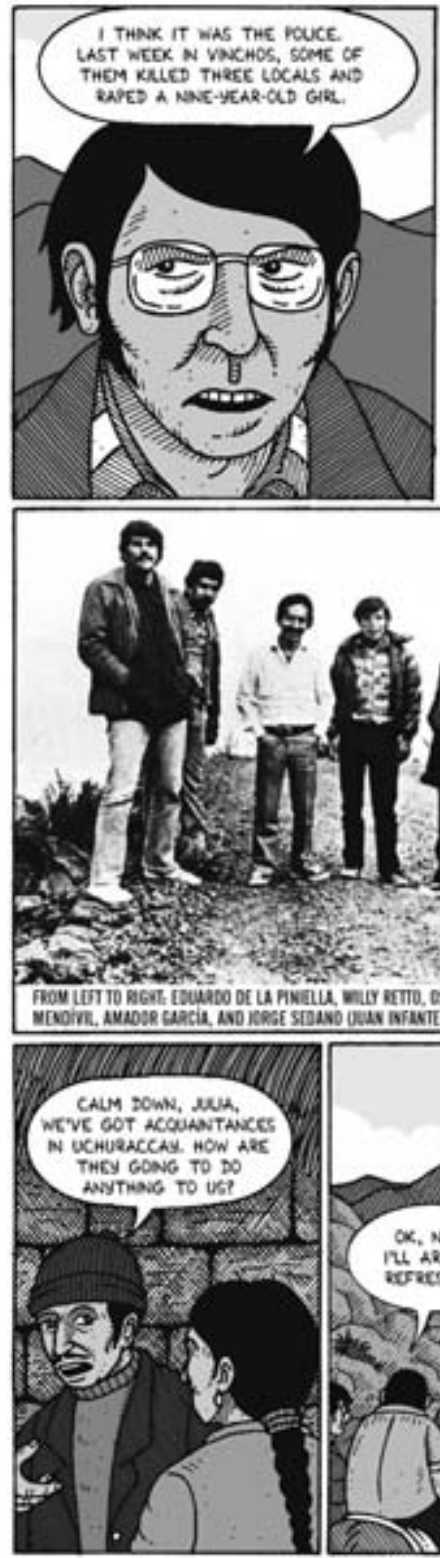
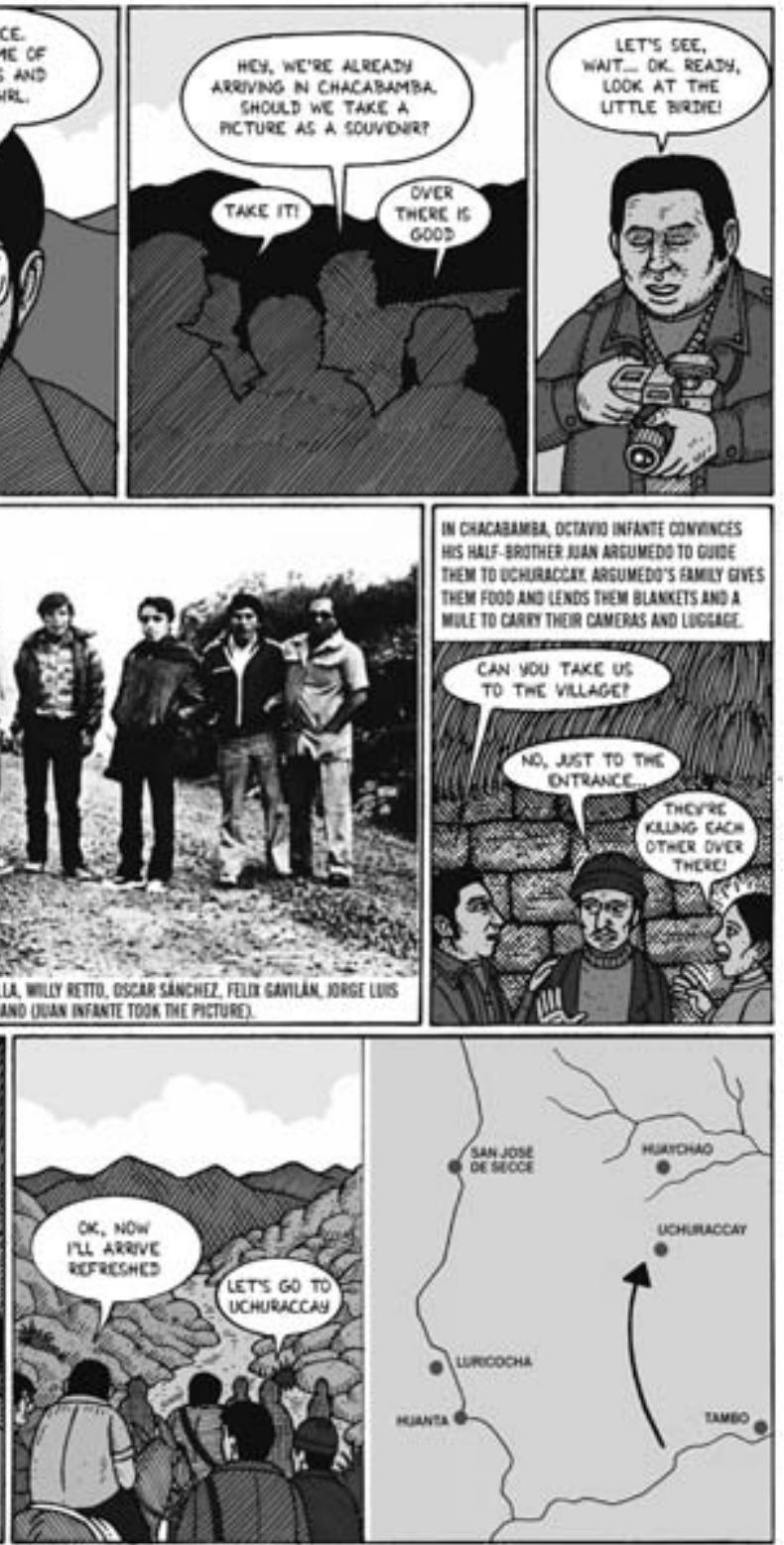

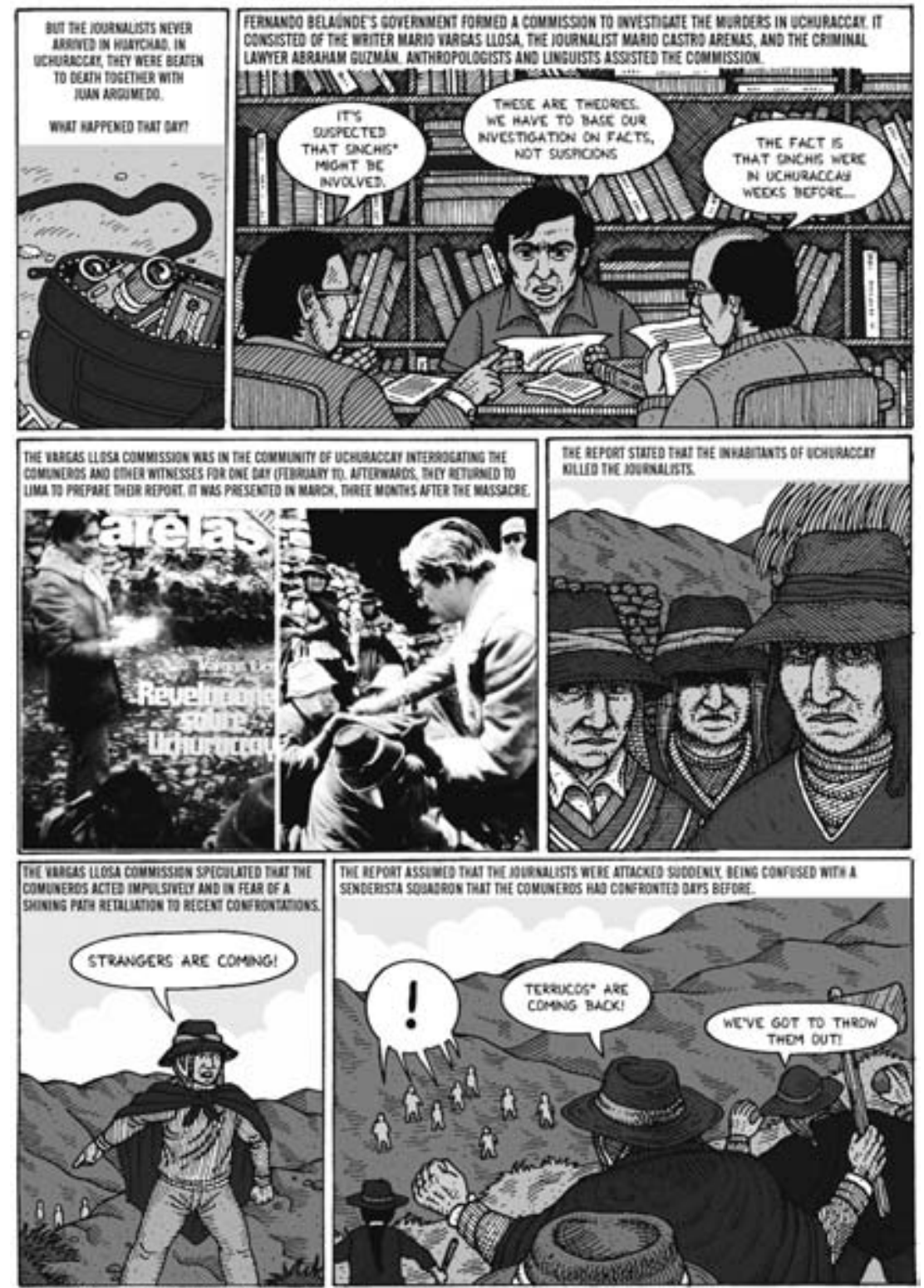

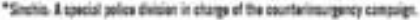




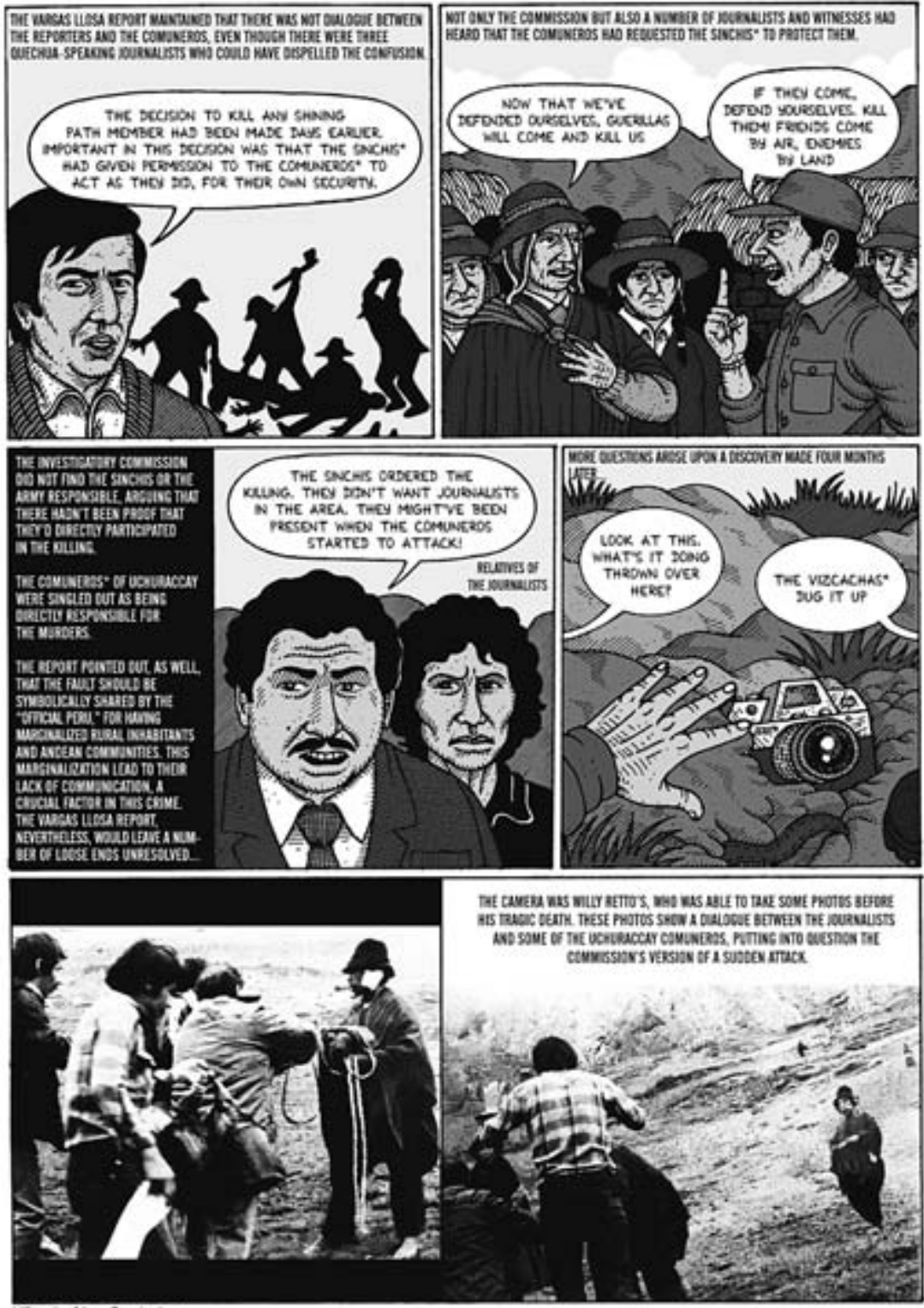

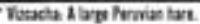




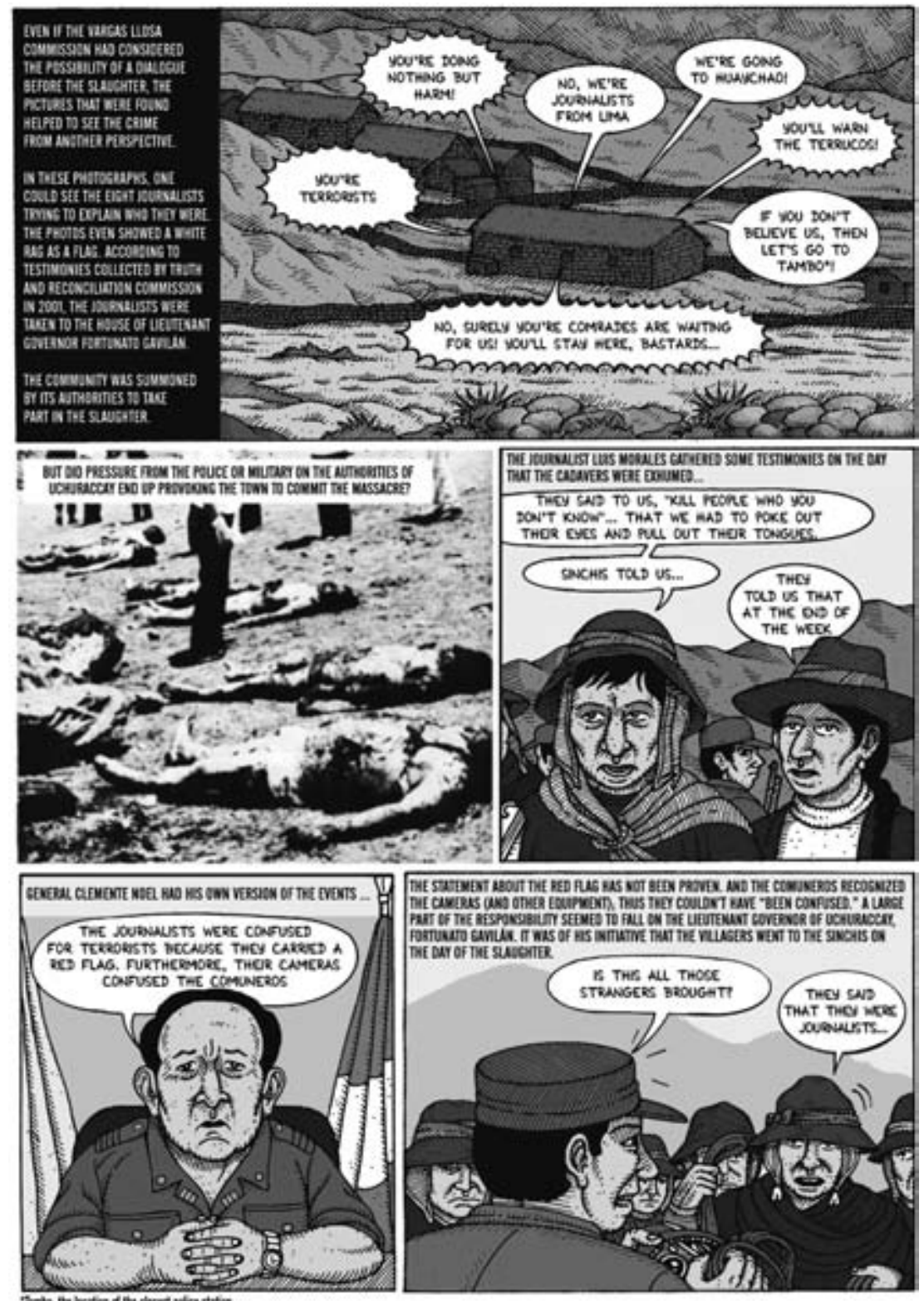

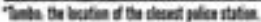



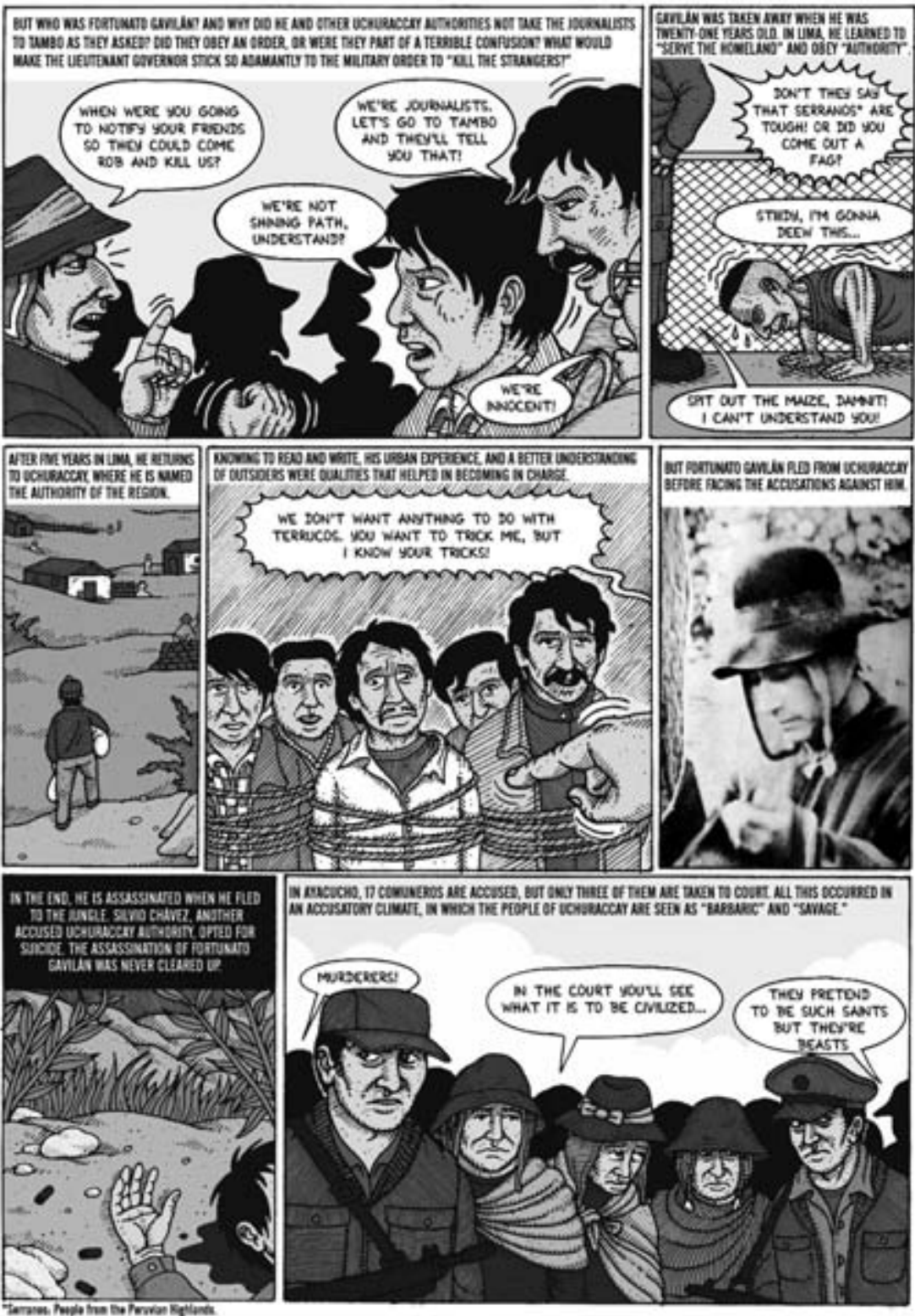

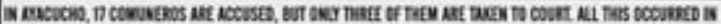

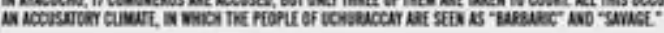

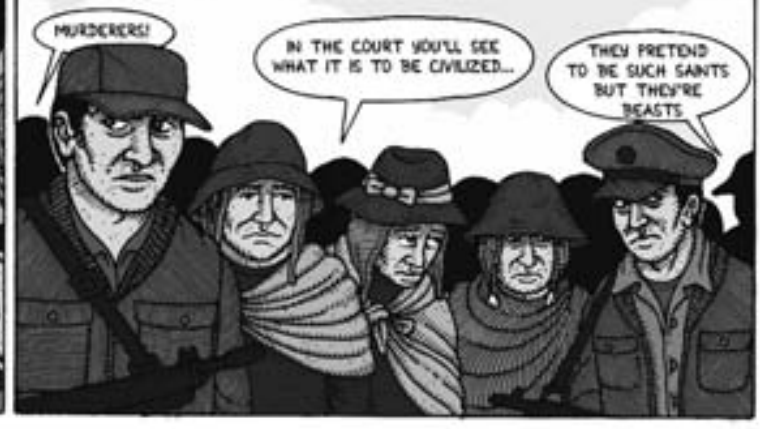



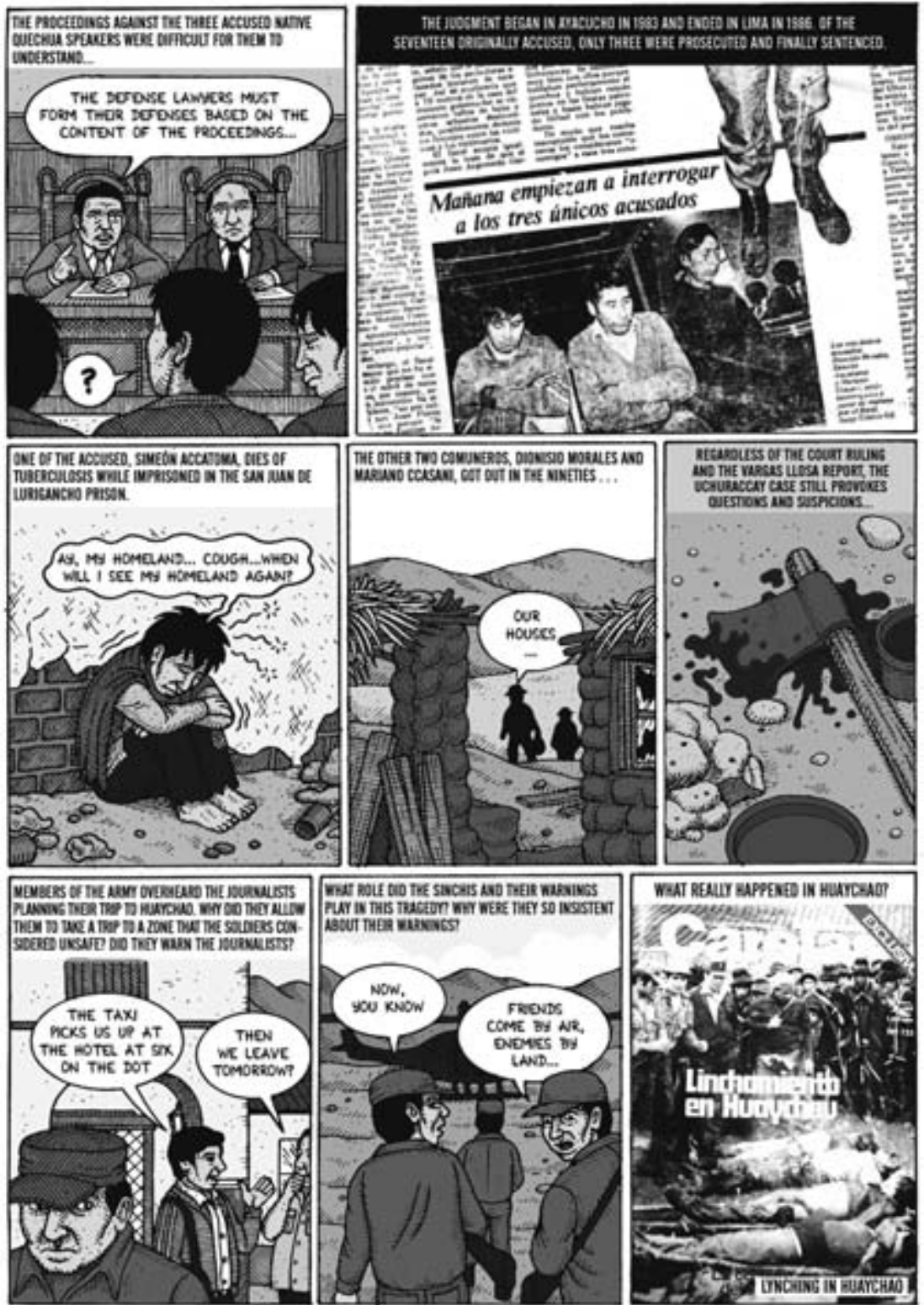


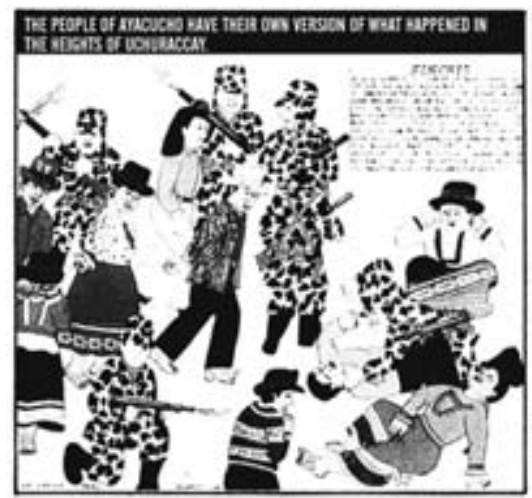

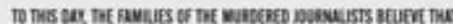

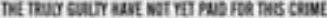
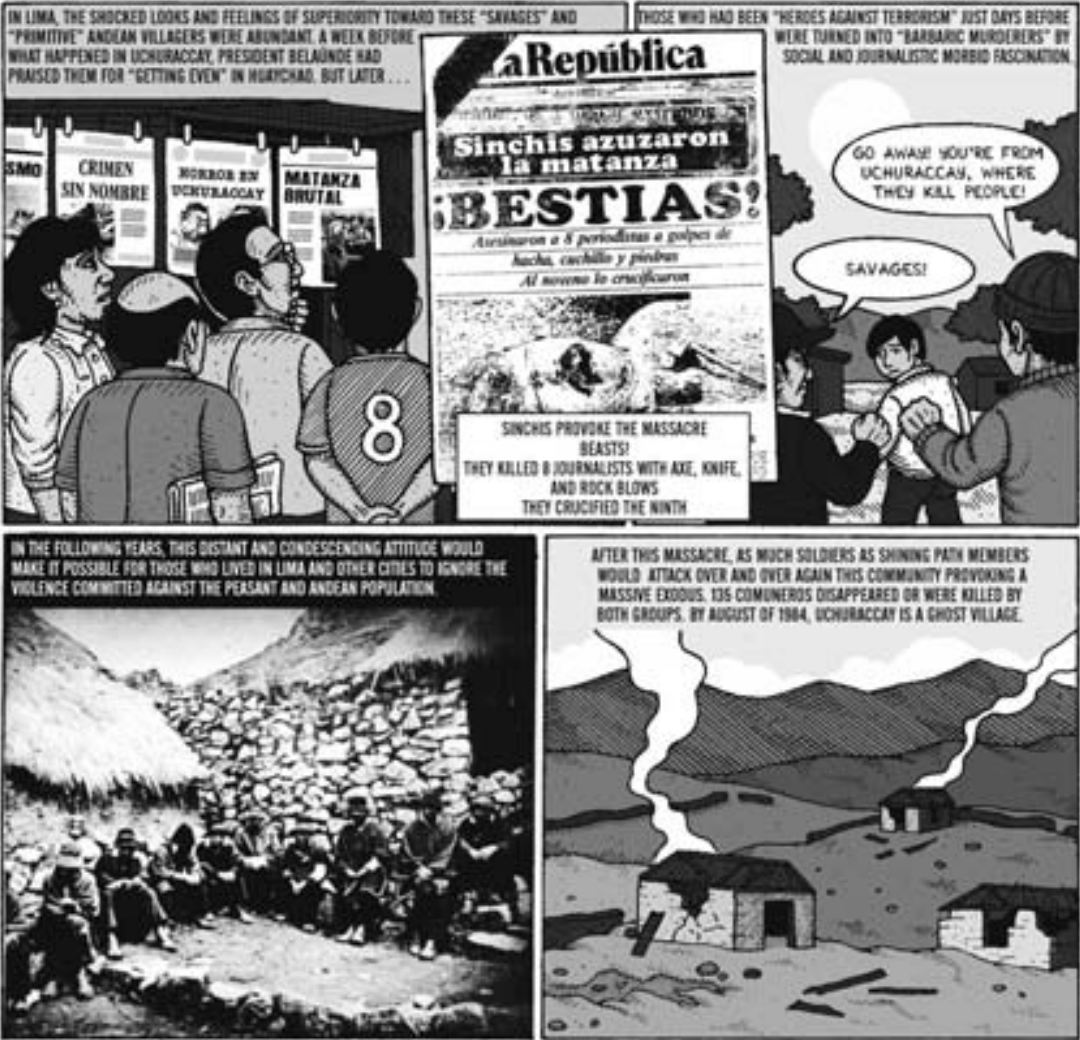


\section{(HI)STORIES OF POLITICAL VIOLENCE IN PERU / 151}

\section{Notes}

1. In Quechua, rupay means "heat," "fire," and "ardor." This translation is by Jane Remick and is based on the 2008 version. Explanatory notes in excerpt are by Alfredo Villar.

2. On the killings in Huaychao, the deaths of the journalists and guide in the Uchuraccay case, the subsequent Vargas Llosa commission, the lasting effects of these deaths on the people from Uchuraccay, and the national response to them, see Ponciano del Pino, "Uchuraccay"; La Serna, The Corner of the Living, 7-8; Mayer, "Peru in Deep Trouble"; CVR, Informe final, vol. 5, 121-182. 

CHAPTER SIX / PONCIANO DEL PINO

AYACUCHANO CINEMA AND THE FILMING OF VIOLENCE /

INTERVIEW WITH PALITO ORTEGA MATUTE

E

DITOR'S NOTE: In this October 6, 2008, interview with the filmmaker Palito Ortega Matute, the historian Ponciano del Pino explores the cinema boom in the 1990 os and early 2000 in their shared hometown of Ayacucho (also known by its colonial era name, Huamanga) and the choice of the political violence as a direct and indirect theme in cinematic production. ${ }^{1}$ Palito Ortega is well known in Peru for his nine feature-length films that take place in the department of Ayacucho. Ortega's films have been screened internationally, in Lima, and in the city of Ayacucho. In this interview, they discuss several of Ortega's works but emphasize his first film, Dios tarda pero no olvida (God Is Late but Does Not Forget; 1994), and his most recent film at the time, El rincón de los inocentes (The Innocents' Corner; filmed in 2005). Both films recount the years of violence from the perspective of a child. The first film is the story of a rural family harmed by both Shining Path and the armed forces. The second film takes the perspective of an urban family from Huamanga. In this interview, del Pino and Ortega discuss how El rincón de los inocentes makes a critique of the Peruvian truth commission and how this film offers a distinct narrative of the war years.

Trained as a visual anthropologist and attracted at a young age to the potential of film as a medium of creative expression, Ortega reflects on the importance of cinema from the provinces as a testimonial artform. Unlike the films produced in Lima that are influenced by Hollywood and Mexican cinema, provincial films draw from local customs, festivities, and mythology. Importantly, films made in the provinces portray daily life. Until the early 200os, Ayacuchanos could watch 
Ortega's films and sometimes see their own streets and their own faces on the screen of a local theatre, which has since turned into an evangelical church. Despite the lack of a theatre, movies continue to be made in Ayacucho and other provinces by young cineastes following in Ortega's footsteps. And almost every year Ortega tries to show El rincón de los inocentes in Ayacucho. Since this interview was conducted, Ortega has created Dios perdona el pecado, el incesto no, Jarjacha III (God Forgives Sin, Not Incest, Jarjacha III; 2009) and La casa rosada (The Pink House; 2013). La casa rosada tells the story of an Ayacucho family: the mother is killed, the father is accused of terrorism and is tortured in the "Pink House," and his children desperately search for him. This house, which still stands today, has since been painted blue.

DEL PINO: I would like to explore three areas in this interview: first, [to talk] on film and whether one might speak of an Ayacuchan cinema; second, to talk of your experience as a filmmaker, taking into account that your origins are in Ayacucho and [the fact that] you lived here during the years of violence. Third, if we could elaborate more specifically on your film El rincón de los inocentes, which deals with insurgent violence and military repression in the city of Ayacucho. I wanted to discuss this film in particular, although you've told me that your other six films also deal indirectly with, or are framed within, this same violent scenario.

Let's begin by speaking about cinema, and more specifically, about the cinema of Ayacucho.

ORTEGA: Well, in Ayacucho there is no enduring style or school of filmmaking. There have been attempts by a number of young people, born out of enthusiasm for picking up a camera and producing [films] on various stories that they have written themselves or that are based on various events that took place in Ayacucho. All this is thanks to the democratization of digital video technology. Beforehand, such possibilities did not exist in any part of the world. This format has been a boon to many who have wished to tell stories. Ayacucho has been among the places that have seen a large trend of young people trying to make films, right? But digital videos have stalled, and these young people have not gotten beyond this stage of production. But, personally, I have indeed taken this very seriously, with a good deal of responsibility. I have taken it on as an 
occupation, as a professional in the art of filmmaking. I've now spent close to twenty years in the world of visual arts, and I have seven feature-length films to my name. This gives me a bit of permanency and currency to be able to call myself — and to have myself called-a filmmaker.

DEL PINO: When you refer to these young people who have tried to produce films thanks to digital cameras, we're speaking of the 1990s?

ORTEGA: We are talking about the 2000 .

DEL PINO: Quite recent, then.

ORTEGA: It is recent. This trend in Ayacucho was sparked by a feature-length project that I made here in the region. Young people were left with an enthusiasm for filmmaking. What's valuable in all this is that they have done it: they tried to create something without the technical requirements, without, in truth, any of the conditions that a film production ought to meet in terms of all the parameters of technique and structure; nevertheless, they have done it. And as with these experiences in Ayacucho, there have been similar developments elsewhere in Peru.

DEL PINO: In the provinces?

ORTEGa: Precisely. Puno is another of the places where there is also an important trend among young people trying to make feature films. One or two of them have achieved a national presence, due to their effort, their perseverance, and their obstinacy, because to make a feature, be it in Ayacucho, in Lima, or in any other part of Peru, is extremely difficult.

DEL PINO: What kinds of films have been produced by these young people?

ORTEGA: This is what is so interesting in this great movement that has blossomed in Peru. It is in contrast to the centralist gaze (I'm speaking of Lima), in contrast to those Lima filmmakers who are suddenly telling stories that are infected with Mexican or American cinema, with cultural influences that are not necessarily Peruvian. Those of us who are trying to create a provincial cinema, we are doing something exceptional: we tell daily life; we tell culture; we narrate; we show the essence of Peru. This is the key difference [between provincial and Lima-based cinema].

DEL PINO: When you say "the essence of Peru," are you referring to portraying popular celebrations? What particularities of this "essence of Peru" are represented in these films? 
ORTEGA: Everything from folkloric topics, such as festivals, customs, and Andean myths, to very serious subjects, as in my case. I have developed themes related to sociopolitical violence, from my own point of view, of course. In the great majority of places in Peru where films are being made, the youth are playing with topics tied to their own region[s], things that they know.

DEL PINO: These young people to whom you refer, are they also broaching the subject of political violence, or is it much more about customs and mythology?

ORTEGA: Mythology. I don't know of one instance in which they've touched on themes tied to the political violence or on any other subject related to the history of their region. They are essentially playing with the genres of suspense or terror, taking themes or pulling subjects from Andean mythology. Topics such as the Qarqacha or Pishtaco [mythical malevolent figures]. The Kharisiri in Puno, for example, which is a sort of Qarqacha or a kind of Pishtaco. ${ }^{2}$ In a few cases, they are dealing with contemporary themes, for instance, society's abuse of vulnerable persons, such as children.

DEL PINO: What kind of reception has the population given these films of a social or traditional bent?

ORTEGA: There is one thing that I want to emphasize about this phenomenon of provincial film, and that is that the average contemporary Peruvian wants to see himself or herself reflected on a screen, of that I'm quite certain because of my own experience. For example, here in Ayacucho when we make a film of a social or traditional nature, the public goes not only to see the story but also to see their street, to see their neighbor who acted in it, to see themselves reflected on the screen. This is quite interesting, and the same thing happens in other regions. And so success at the box office is ensured. Any film that has been made outside Lima, in the provinces, whether in Ayacucho, Puno, Huancayo, Juliaca, Cajamarca, or Cusco, has an audience that follows those features.

DEL PINO: Though perhaps at the risk of remaining limited to local and regional audiences and not, therefore, reaching a broader public such as that of Lima?

ORTEGA: There have been a few attempts by certain provincial producers who have taken their films to the capital, to Lima, but the reality is otherwise: the market for film production is dominated by a monster called "Hollywood." So no Peruvian production, not even those made in Lima or by directors or 
producers from Lima, has the same possibilities or position as those distributed by Hollywood. This, then, is a major limitation. Certainly, the efforts that these young people have made have been stopped short at their beginnings. If we had the same opportunities, these films could have a much greater impact at the box office, because more or less 90 percent of Lima's population is from the provinces. As I said before, the provincial people want to see themselves, they want to see themselves on that screen. If we had the opportunity, these productions could gain a huge following.

DEL PINO: Let's move on to your own experience. Tell us a little about your experience being born and growing up in Ayacucho, and about how you later became involved in film production.

ORTEGA: Very well. Yes, I am from Ayacucho. I was lucky to have lived and witnessed the process of political violence in Ayacucho. I say "lucky" because this is what permits me a certain proximity to that reality and what enables me to tell these stories in a closer way, with convincing details, to portray realistically those years that were so hard. With regard to my inclination for filmmaking, it dates from childhood. I remember vividly how powerfully my attention was caught by the camcorders of tourists during Holy Week. I saw them as inaccessible things, thinking that I would never have the chance even to touch such cameras. But as the years passed, I tried to make some cinematographic works using very amateurish cameras. In a way, that allowed me to gain a certain proximity to the work of filmmaking; it left me feeling a need to study introductory courses on filmmaking, courses on camera-work, on directing. Then, for many years, I had this intention, this ambition of wanting to make a film, but I was conscious that behind it all there was a series of things that were still out of my reach, beginning with a camera.

I studied anthropology, and involved myself with visual anthropology. I began by developing some projects related to the violence in several communities outside Ayacucho. I also did work for a number of foreign television channels and for national television. This, then, allowed me to gain a more direct understanding of how a documentary or feature film might be developed. At this point, I was dreaming of a feature film, of telling a fictionalized story. So then I began working bit by bit; the first thing I did was write some stories, but I wasn't satisfied with what I was writing. I needed stories that could really have an effect 
on their audience. It was a learning process for me, until the point when I was certain I had written a story that would work; it was Dios tarda pero no olvida (God Is Late but Does Not Forget), the first film that I made.

DEL PINO: In what year?

ORTEGA: In 1993. With the story in hand, I started working on the following elements: getting a good camera, getting actors, and getting a bit of financing, which I raised though loans from my family and the actors' own contributions.

DEL PINO: In that film, God Is Late but Does Not Forget, the actors were . . . ?

ORTEGA: Locals.

DEL PINO: From here [the city of Ayacucho]?

ORTEGA: From here. The good thing was that these local actors from Ayacucho had a calling, had ambitions to become actors, which is very important, even though they had no academic training. What I did to avoid weaknesses in the acting was to have this group of people train with an expert acting teacher.

DEL PINO: How long did that take?

ORTEGA: Close to eight months. This period, I can see now, was also a learning process for me. During rehearsals, these actors didn't have the strength that I wanted to see in them. And so I was a little disappointed, but in the end, the project was already under way and we were going to do it regardless. But the funny thing is that the local actor, who was given eight months to prepare, at the moment of my saying "action," the magic word to start the takes and scenes, he suddenly became the actor I was searching for.

DEL PINO: A complete transformation?

ORTEGA: Precisely. There is a tremendous predisposition, a magical predisposition in these actors, and in the end the project, the film worked very well in terms of acting; as a story it worked very well, as a new proposal for Ayacucho: it was the first film made in Ayacucho, and it worked very well. The inhabitants responded to that novelty.

DEL PINO: This was the first film made in Ayacucho?

ORTEGA: Yes.

DEL PINO: What is the story of God Is Late but Does Not Forget?

ORTEGA: I wanted to make a film that was somehow related to the political violence, but I was a little afraid, because even at that time, elements of the armed forces and Shining Path were still present in Ayacucho. But I used the 
problem of terrorism as pretence to create a story about a youth who migrates, who comes from the countryside to the city [of Ayacucho] because his family was killed by Shining Path. I took up this issue as a pretence, as the story itself is not about terrorism.

DEL PINO: So it is the story of a displaced youth looking for a refuge, fleeing his community because of Shining Path violence?

ORTEGA: It is about life in the city. He finds himself in a reality that he had not imagined; he thought that he was going somewhere like his own community, but he encounters a city, a monster, where the indifference of society is terrible, obvious. So he confronts this society, on top of having escaped that climate of political violence. That provides dramatic elements sufficient to making the film work well.

DEL PINO: As you were creating this story, you came to know the experience of displacement intimately, you explored life histories. Of course, for someone who lived in this city, these were part of everyday reality in an urban landscape transformed by violence. Did you undertake any kind of research that allowed you to understand in depth the experience of being a refugee?

ortega: These were persistent facts in Ayacucho. One knew that many people came from the countryside and had moved to the city of Ayacucho. So we knew about the displaced, about the people who were fleeing from terrorism or the military in the countryside. The particulars of the film, of the boy who flees the countryside, are a story that had happened, that I had been told, and I used this story of one family that lived through this disgraceful period, and whose story is narrated in the film.

DEL PINO: The film was released here in Ayacucho.

ORTEGA: In Ayacucho, it was in theatres for a long time, for close to two months during its first run, then two months of rerelease and then another month again of rerelease, a very long spell. And it also showed in Abancay, Andahuaylas, Cusco, Huancayo, Puno, Juliaca, and Huancavelica. The reaction of the audience was similar to that in Ayacucho. It seemed these places had lived through the same problems as the boy in the film. There was a tremendous amount of identification.

DEL PINO: How old is the boy?

ortega: Nine years old: Cirilo. 
DEL PINO: Is it a film that narrates his life as a child, or is it about a boy becoming an adult?

ORTEGA: No, he remains a child. The story covers approximately two months. DEL PINO: When was the premiere?

ORTEGA: We started working in early 1993, writing the story, preparing the actors, obtaining necessities, and in late 1993 we started filming. The shoot lasted for a year. The premiere was in 1995 or 1996.

DEL PINO: And in Ayacucho, what was the reception like?

ORTEGA: It was unbelievable! It was quite surprising for me because I had initially planned to have just one showing. I wanted the theatre to be full, and I was content with one screening because I cared more about showing this story than turning a profit. It was extended for two months of screenings in Ayacucho. It was something incredible. The theatre was completely full. In this regard, I did not have the mind of a producer. What a producer does is get money, make money, and earn money. What I wanted to do was show the film, and in that I succeeded. The ticket price for the theatre was two soles, which is nothing. But for me it was something encouraging. It allowed me to continue pursuing this occupation. Had it gone otherwise, I would have abandoned filmmaking and devoted myself to anthropology.

DEL PINO: I don't know if you paid attention to people's comments; what were they saying about the film?

ORTEGA: Oh, there's so many anecdotes about this. It became kind of mandatory in Ayacucho to see this film. Come the weekend-the film was shown only during the weekend[s], Saturdays and Sundays, with two screenings each day - the town square would resemble a fair with all the people lining up to see the film. It was shown in the municipal cinema, a venue with about four hundred seats. But the people in the queues exceeded that number. So you can see just what a phenomenon it was to show this first Ayacuchan film.

DEL PINO: How did you get the word out? How did people hear about you, this being your first film?

ORTEGA: For the first screening, we used a bit of marketing-radio ads and local television, Channel 7. It was the only channel in Ayacucho and everyone watched it, especially the news. We ran our ad on these media and tried to attract people with the novelty, the fact that this was the first Ayacuchan film. In 
the wake of the political violence, there was nothing to do in Ayacucho; there was no entertainment, there were no parties, there were no nightclubs. Basically, it was almost a ghost town. From seven o'clock in the evening, people were in their homes. But surely it was the novelty of wanting to see this film from Ayacucho, filmed in Ayacucho and by people from Ayacucho, that brought them to the screenings.

DEL PINO: Tell us about the experience of making this film, as you were doing it here, with limited resources. What were the greatest hurdles?

ORTEGA: The whole film was shot with just one camera, except for the action scenes. In fact, we encountered difficulties. I was conscious from the beginning of not having a budget that was underwritten by a sponsoring company. The challenge was rooted, essentially, in not having any money we could count on. Because of this, the project was delayed for about fourteen months. Moreover, there was the difficulty of not having the support of the people who are responsible for fostering this kind of cultural activity in Ayacucho, such as the municipality. Despite the fact that we were constantly sending them documents letting them know what we were doing, asking them for a little help-like with fuel or a vehicle for our transportation - we never received any reply. They aren't obliged to support us, but they do have a commitment to society to foster culture; yet, they did not do this. But, we were able to overcome these financial problems through perseverance, not only on my part, but also that of the actors who were fundamental to this project. They did not collect a single cent of salary, except for one actor.

DEL PINO: How did you recruit your actors?

ORTEGA: All of this was new for Ayacucho. I didn't know people working in theatre; I didn't have friends who had a passion for acting. So, I made some radio announcements and [got] some posters posted around the city. This worked well: close to four hundred people appeared for the casting auditions that we held in Ayacucho. From this number, first close to two hundred people were selected, and finally I chose eighty actors with whom we finished the preparations and worked on the film.

DEL PINO: Tell me about the evolution of your filmmaking process. I was told there have been seven feature-length films, the first two being God Is Late but Does Not Forget I and II. 
ORTEGA: There have been three stages to my career. I'll explain various aspects of the first stage. Above all, at this stage there was the issue of technique and of my evolution as a professional in this field. This first phase of my career begins with God Is Late but Does Not Forget and culminates with the final film of the God Is Late trilogy, called Innocent Blood, a film that does address directly the theme of political violence. By the end of this phase, I had improved my abilities; I took advantage of the digital technology that came to Peru in 2000. I began a new stage in my career, adopting digital technology as my principal tool. Before this, I worked with analog formats, with almost amateurish parts or cameras - with Super VHS cameras - which were not the standard format, not even for television reports. It was a format more like that for home video use, but of a better quality. I made do with this format out of necessity because I didn't have access to the resources needed to obtain a higher quality format. The second phase marks my transition to digital cinema. This new tool came not only to Peru, but also started being used throughout Latin America and globally. I made two feature-length films using this digital technology, also with actors from Ayacucho. I'm referring to Incest in the Andes and The Curse of the Qarqachas $I$ and $I I$, which is a theme taken from Andean mythology. And the third and, I believe, final phase is to venture into producing films specifically for cinema with a digital toolkit and with actors who already have experience in national and Latin American films, beginning with The Innocents' Corner. I have had two more productions since Sin and God Forgives Sin, Not Incest, which became the Qarqachas trilogy. But I had a new perspective, with a new technical approach and a new acting approach, with the elements that film production requires. These are aspects of technique, of acting, of storytelling.

DEL PINO: In terms of the technology you've used, you see three moments in your evolution. But in terms of the subject matter you explore, is there likewise an evolution or change?

ORTEGA: I am passionate about dealing with subjects related to sociopolitical violence, out of a moral obligation to tell stories not created in my head, but by reality. I've lived though it in Ayacucho. Living in Huamanga [the city of Ayacucho], I was affected by seeing up close the magnitude of this vortex. I am a witness, and moreover, a victim of both sides: Shining Path and the military have each caused me significant harm. If you want me to tell you the details, 
Shining Path sent me a letter threatening me with death because I was a leader in a certain [political] party that operated in Ayacucho, the leader of a youth wing.

DEL PINO: Of the Aprista youth?

ORTEGA: Well, yes. I didn't want to say which party, but yes, of the JAP [Juventud Aprista Peruana, Peruvian Aprista Youth]. So they [Shining Path] sent me a letter in which they also included some other names of certain leaders of APRA [Alianza Popular Revolucionaria Americana]. By my good fortune, I was still young, this alarmed my parents, and the next day they sent me to Lima.

DEL PINO: When did that happen?

ORTEGA: That was in 1986. They sent me to Lima immediately. They protected me, is what they did. I didn't agree with my parents' decision because I was young; I was a rebel; I was also a fighter for my Aprista [the APRA political party] cause.

DEL PINO: That was at the beginning of the [first] Alan García government [1985-1990]?

ORTEGa: Precisely. I didn't want to disconnect myself from that cause here in Ayacucho, but my family's pressure was more powerful. And so I went; they took me to Lima. And the next day, we learned from the news that they had killed this person, that person, people who were on the list that Shining Path had drawn up that I was also on. Well, I returned for a visit after a year or two. It was at that point that Shining Path planted dynamite in my house. I am also a victim of the armed forces. They got into my house on two occasions. The first time, they took everything, and the second time, they raided the house and took my father away. They disappeared him. But God is great and this disappearance lasted only one night.

DEL PINO: This was before Shining Path's assault?

ORTEGA: It was after. The third thing that happened to me was at the hands of the military: they took me to the Casa Rosada. There I was tortured, beaten, like everyone who entered the Casa Rosada. I was absolutely innocent. But as all people from Ayacucho were suspected of being Shining Path or terrorists, to them I was also suspect.

DEL PINO: That was toward the end of the 1980s?

ORTEGA: That was in 1988 or 1987, I think. 
DEL PINO: So this experience, as with many people from Ayacucho, shapes your output, which in your own case is cinematographic?

ORTEGA: Even if one has not lived through these difficult experiences, the simple fact of being from Ayacucho gives one the ability to tell stories in a different way: real, you see, because it's been lived. We are the only ones who know what really happened in Ayacucho: what degree of responsibility lies with Shining Path and what degree of responsibility lies with the military. But furthermore, having lived this experience so closely myself, I think it gives me the power to tell these stories as they were. It is my duty. My conscience compels me to tell these stories without manipulation, without machination, without elaboration: this is the history that happened in Ayacucho.

DEL PINO: Perhaps it is both-of living in Ayacucho and of having experienced the violence-that gives you this moral mandate to say something about what transpired. And the result is desire to represent this experience through film.

ORTEGA: Well, initially I didn't know that this was going to happen in Ayacucho. DEL PINO: Of course.

ORTEGA: I have always been drawn to the camera. I never imagined that the coming years would bring what they did to Ayacucho. I think that is one facet. It's a good subject for a film, right? Thank God, I say, for having lived through that phase so as to be able to tell stories in a real way. But I am grateful for what I have witnessed. It sets me apart from other productions made in Peru, like those of Pancho [Francisco] Lombardi, Fabricio Aguilar, or Mariane Eyde; I am sure that they have based their scripts on bibliographies, from newspapers, drawing on information from books. Not me. I don't need to read books. Of course, I do read books, but for me it was enough to have seen, for me it is enough that my neighbors and my friends tell me their stories. Each neighbor has his or her own story. Each friend has their own story. And so even fictionalized, even as a story I'm creating in my mind, the stories that I can create are very close to the reality.

DEL PINO: Seeing as you have your own experience and every experience is unique, in developing a script, how do you negotiate among these distinct experiences and different perspectives to form a fictionalized account?

ORTEGA: It's somewhat complex. Film is purely artistic. In my case I prefer that my films be more historical. I try to represent things as they were, right? And sometimes I get outside the boundaries of storytelling in the scenarios in a 


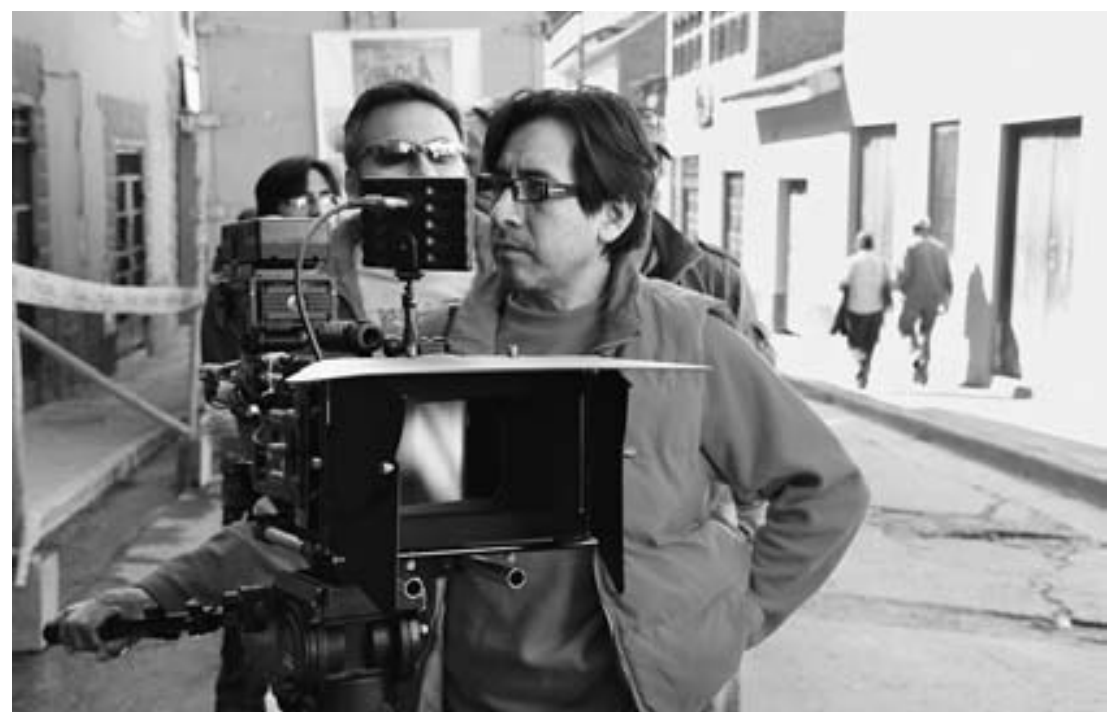

FIGURE 6.1. Palito Ortega filming La casa rosada (The Pink House; 2013) on set in Ayacucho. Photograph reproduced with permission from Palito Ortega.

script. And I have trouble; many friends who are screenwriters tell me, "No, try to make it this way, create it that way." That would mean getting rid of some of the elements that belong to real life. And so I've broken away from that rubric, from the question of a cinematographic script. In any case, I want to make mine more historical. I always say that my movies help serve as documents on film, so that later it will be said, "That's the way the violence was." Because of this, I try as much as possible not to embellish.

DEL PINO: This explains why, and I'm thinking now particularly of the film The Innocents' Corner, one of the greatest achievements of your oeuvre is to show daily life, what it meant to live the years of violence in this city. One can feel that atmosphere of what it was to live through the dark nights (without electricity), with the assassinations, the sleeplessness, the gunfire in the night, the explosions, and the insecurity to which one was exposed.

ORTEGA: That is what you will not find in books, never in the writings of the "Senderologists" [experts dedicated to the study of Shining Path]. You will only hear that [the experience of the violence] from the people who have lived through it, right? I've lived that, and I put part of that life that I had into my 
films. For instance, the fact that when there is gunfire, one automatically, instinctively, gets under the table. That was an everyday thing, part of daily life. I remember that one Christmas, we were on the second floor of my house, in the dining room. We were having some chocolate with panetón [sweet Christmas bread], nothing else, there were no cohetecillos [Christmas noisemakers] because they weren't permitted. Only a few little candles. And suddenly we heard the bombs, the explosions, and what we did was grab our cups and take our panetón under the table. Lying or sitting, we had it there. We had already become accustomed. We no longer reacted [by thinking about it].

DEL PINO: Right, I believe that's a scene that really caught my attention in the film's first moments. Now I understand you better when you say that more than a fictionalization, you aim to make of your film a historical document. This explains overtly showing the brutality of the aggression that the inhabitants suffer at the hands of the military and through the Shining Path's crimes, or not?

ORTEGA: In a sense, I try to delimit that rawness that was suddenly there. Because one way or another what I do is film, right? In order to maintain a tolerable balance, in order to keep the viewer from falling into morbidity, I've often felt obliged, against my own wishes, to cut out certain things that have been told to me. For example, I have been told that in the Casa Rosada, women were tortured with live rats that were put into their vaginas. This, for instance, could never work. It's too much. There are films that have been made outside Peru with subject matter that also included a lot of violence with quite forceful depictions. But I didn't want to go to that extreme.

DEL PINO: So, then, there is a moral dimension to the limits of your telling or not telling of certain stories. What are the parameters for you? What are the principles that keep you from displaying that morbidity in your portrayal of violence?

ORTEGA: Every film is subject to criticism. And the critics would be harsh, they would be cruel if I had included elements of that sort. Additionally, so as to keep from becoming grotesque, and thereby breaking the film's dramatic power, it is not possible to show cases like the one I told you about. I also do it as a matter of personal morality. I was brought up in a Catholic family that believes in God, and from a certain point of view, such things would not be appropriate in a film. 


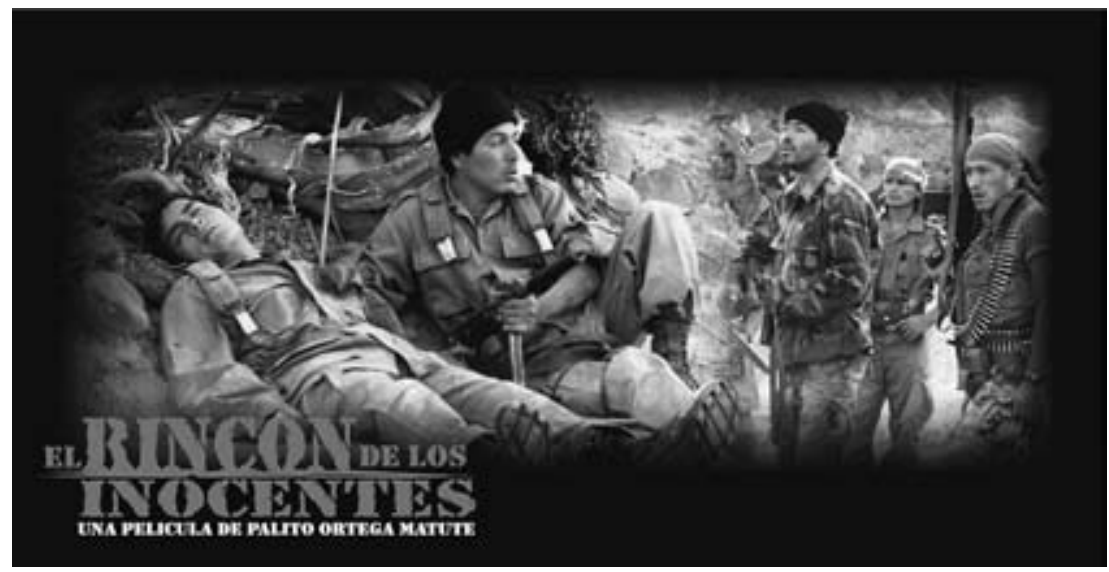

FIGURE 6.2. Publicity for El rincón de los inocentes (The Innocents' Corner; 2005). Reproduced with permission from Palito Ortega.

DEL PINO: When I watch the film, it deals extensively with military repression. But there is something more than simply military repression. Isn't it a repression not just of a potentially insurgent population, but rather of the inhabitants of Ayacucho, of the highlanders, who are seen as less human than the soldiers?

ORTEGA: [It is] racism.

DEL PINO: I don't know whether you've considered [racism] as a topic?

ORTEGA: There is a certain degree of racism on the part of the soldiers, isn't there, of seeing someone from the provinces as a "little Indian," in quotation marks, of course. This has contributed to making the savageries that they committed more flagrant, because if the violence had begun somewhere other than Ayacucho, say in Lima, I don't believe that the brutality that was employed here would have been used in Lima. But also, to see a person of humble origin, dressed differently from how they dress in the city, a person who doesn't know how to communicate with soldiers because he or she speaks Quechua, a person who conveys a physical impression of humility; I believe that they [the armed forces] took advantage of that aspect as well. There has been a pronounced degree of racism in this counterinsurgency struggle.

DEL PINO: A third element of The Innocents' Corner that strikes me as interesting is the question of who has the right to represent this past, a subject that 
is brought to the fore in a notable way in two instances in the film. On the one hand, there is the presence of the journalists coming from Lima in the context of the Truth and Reconciliation Commission's [CVR] work, looking for "news," the most dramatic story. And the narrator, the boy who grew up in it [the city of Ayacucho], realizes at one point that these guys simply do not or cannot understand what he is trying to tell them, what he has lived through. The other instance is the confrontation with the CVR's legitimacy in seeking to represent the past. The film not only suggests that outsiders are unable to narrate the violence, but also questions how they can even come to understand what people here have lived through.

ORTEGA: A boy who had a difficult time: he lost his parents; he fled; then he returns as a grown man to give his testimony. The controversy around the CVR is that for many people in Ayacucho, the testimonies were manipulated. In this case, the young man in the story lets himself be manipulated a little. He realizes that this is not a group of journalists working for a television station, but rather that they work for the CVR, which had a press and communications department. I have producer friends who have worked for the CVR doing this kind of work. That's where the idea comes from, this part of the truth commission's work that certainly displeased so very many people. So this youth's rejection of it in removing the tape and throwing it into the river is an absolute need that he feels. Countless people disagree with the truth commission's process. In the scene at the CVR's public hearing [audiencia pública], the now grown boy airs his point of view, showing what the truth commissioners who didn't know Quechua are made of, and rejects their outlook. And this very point has been widely debated in Ayacucho. What use is a commissioner who, with the exception of one or two [words], doesn't understand Quechua? It was necessary for these people [to] be well-informed about each testimony so that they could fully understand the suffering of that person, of the family, of that victim. And this is certainly a great metaphor and, as I said before, a collective need of Ayacuchan society.

DEL PINO: This is ultimately a metaphor for the nation's botched encounter.

ortega: Above all in Ayacucho. I've heard these kinds of comments in Ayacucho. In Lima, I had a lot of friends who worked for the CVR, but they never said anything like that to me. Here, yes, and not only from people who had participated directly by giving their testimony or from their families; rather, 
the people as a whole disagreed with certain things. I felt a moral obligation in the film to represent these objections, though of course to a lesser degree. This certainly isn't an indictment of the CVR; it's only intended to tell them that they were wrong on these points. Because surely the work of the CVR is an abysmal assignment, it's an enormous job that deserves our respect, and one ought to keep in mind certain figures like Salomón Lerner, who has considerable integrity by all accounts.

DEL PINO: In any case, I really liked that metaphor of this disjuncture in the country. On the other hand, it calls into question the legitimacy of representing that past. To what degree can people who are not part of this experience or have not lived through it represent that experience? Is there a moral imperative concerning the legitimacy of representation?

ORTEGA: It's a twofold grievance: the first is to have lost someone close to you; the second is that here comes a person-this has occurred to me-a stranger to the violence, drawing a fantastic salary, who is thus living off the suffering of these people, profiting from the pain of others. That has been said. It's not a point of view that I defend. I am a communicator, and I have a duty to convey that with which a community, a society as a whole, takes issue. In fact, we do agree, don't we?

DEL PINO: Although the film is very critical of Cipriani [bishop of Ayacucho, 1988-1997] and of the role of the Church, we don't see the face of civilian authority, even though the repression in fact took place under two civilian governments in the 1980 .

ORTEGA: In that respect, the authorities in Ayacucho were practically inhuman. Essentially, no authorities existed, and if they did, where were they? That's why these authorities are absent figures. And when they are represented, as with the judge, it is to demonstrate their indifference to what the people are suffering. At the beginning of the film we do make a reference to the governments of Alan García and Belaúnde; the worst phases of the political violence happened during the years of the Fernando Belaúnde and Alan García governments.

DEL PINO: Moving on to speak about the art itself of representing this experience-you started with God Is Late, which is the story of a boy, and in The Innocents' Corner the protagonist is also a boy. Is there something particular about the presence of a child in the scripts you develop? 
ORTEGA: Now that you mention it, I confess it was done unconsciously. Perhaps the gaze of a child is my perspective because I lived through these experiences at an early age, and I identify with these boys. In addition to the age, there is a special perspective, a dramatic power, held by a child as a sublime being in society. I believe a child can easily captivate hearts, easily deliver the message that needs to be conveyed. And the message is this: know that this happened in Ayacucho. This is addressed to everybody, so that the magnitude of this violence can be truly understood.

DEL PINO: The boy, then, embodies innocence and vulnerability in the face of what society was exposed to. Thinking about your audience, are you contemplating a more universal public, or a more local one, and how might this have changed between your first film and The Innocents' Corner?

ORTEGA: This has also been part of the evolution I've undergone. When I started writing the first film, I began without a particular audience in mind. As I went forward with my career, I became a producer as well, out of a need to recoup and earn money from my productions. And these days, all the more so. It's certainly a matter of thinking of a general audience. I don't want this film to be wasted only on adults' eyes, or on those of children alone. I want it to be a film that will be watched by entire families, I want mom and dad and child to go the theatre and to discuss it. That's my intention.

DEL PINO: When you speak of this family, you mean a family in Ayacucho, or ...?

ORTEGA: The Innocents' Corner is a project with international ambitions, and because of this we worked with all the elements that such a production demands in both dramatic and technical terms. We made this film to be shown globally. As a result, we set high standards for ourselves on every aspect.

DEL PINO: How did people react to the film? How did they receive it?

ORTEGA: Well, the film still hasn't been released on a commercial level, not even in Ayacucho. A preview was held in Ayacucho, a long preview that lasted almost two months. More out of financial necessity than anything, to recoup the costs we'd incurred. Besides bringing in some resources, it allowed me to observe, to see the film's potential, because the people who came to see the film weren't only from Ayacucho, but from all over. We lucked out in that during the preview run there were a lot of tourists in Ayacucho. There was complete 
consensus, among those from Lima and abroad as much as among those from Ayacucho, in saying that the film was very good. Good on several counts, as a story, as a historical narrative; ultimately, this gives me some sway to get a good release, not only in Ayacucho, but nationally and internationally too.

DEL PINO: Among the people from Ayacucho, did you pick up on any common reactions to the film? Could we speak of a pattern in their reactions?

ORTEGA: Certainly. The Ayacuchan audience was definitely capable of embodying the film's pain: it belongs to them. This is our story, part of our lives. Although it might sound like masochism, many people, above all those from Ayacucho, have seen the film two, three times, and the reaction is the same whether for the first or third time: remembering, suffering, crying, achieving catharsis through the film. This reaction, then, according to what many have said, is an opening of their wounds. These wounds will always remain, scarred and dormant, in the mind of each inhabitant of the region. I believe that's the aim of this film, to say that this is not forgotten, so that remembrance continues, so that wounds continue to be opened if possible, right? To speak about it so that it may never be repeated. It sounds trite to say it, but that's how it is. So the profile of this film among the people of Ayacucho is extremely important. People plead with me in Ayacucho: we want to see the film again; we want it screened again; my dad hasn't seen it; my aunt hasn't seen it. We want to convert the film to video because people are asking me for it in this or that place. This makes me think that there a need, of wanting to remember this history, not so much to see a story on film or to see a cinematographic production, because if they just wanted to see a film, there are so many films out there, but they want to see, essentially, the story that's told in The Innocents' Corner.

DEL PINO: In my view, this is the root of your film's success, that it causes people to remember the past, to relive the experience, and to come to recognize themselves in the film.

ORTEGA: Precisely.

DEL PINO: So people see themselves not just as spectators, but rather as protagonists who make up part of this story.

ORTEGA: Precisely because the Ayacuchan is the film's protagonist, an Ayacuchan viewer feels it, lives it, becomes the one who is going through the harshness of the story, right? He is the father; he is the person who was kidnapped by 
the military; mothers are the mothers who are fighting to see their husbands in jail. The [Ayacuchan audience] identify fully with each of these situations, with each of the characters who are struggling for a common end, which is to survive this conflict.

DEL PINO: I remember the film well, and toward the end, when the boy finds himself with a mother who is looking for her son, there is a turning point visà-vis the past. It comes when the woman is no longer daunted by the soldiers' repressive power and talks back to them with spirit, with insults. It's a remarkable passage, a kind of symbolic and emotional triumph over fear. The prevailing order is subverted and the woman asserts herself with dignity.

ORTEGA: With courage.

DEL PINO: It's the moment when people get a release through laughter, when the woman insults the soldiers. It's a celebratory empathy of the audience with the woman's feat.

ORTEGA: It is a celebratory identification; it is to identify oneself with that human drive, survival.

DEL PINO: From my reading of it, I see in this film more than an attempt to represent the violence that tries to depict a particular experience. When I see how people recognize themselves in this story, in the experience of repression and humiliation that plays out, you truly capture people's sensibilities. And because of this, they end up identifying with the film; you make them relive that story as its protagonists. At that level, your art has a cultural and political agenda; it is itself a cultural production. It's an agenda that one can disagree with in terms of its approach, its themes, but what cannot be denied is the way that people recognize themselves in it. I believe this is an achievement. But also, with this film, you offer a distinct version of what took place, and in this way, it's a work that overlaps with the work of the CVR.

ORTEGA: It comes after. Much later.

DEL PINO: You are trying to tell a story that differs from that told by the CVR. That is some part of the motivation, isn't it?

ORTEGA: No. I don't have a bone to pick with the CVR. That was never my intention. It was to convey a body of thought from my people, from Ayacucho. On some points, I was in agreement, for instance in how the people were mocked, 
on top of the pain they felt over losing someone, by having people with egregious salaries come and do things that didn't meet the expectations of so many people.

DEL PINO: In a way, you aim to tell an alternative history?

ORTEGA: Yes.

DEL PINO: In that sense, it's not a bad thing that there are different modes for representing - or for legitimizing a representation of - that past.

ORTEGA: Well, definitely compared to other productions, the film is absolutely alternative, because its perspective is different from what has already been done. It's a perspective that's all at once more convincing, more real, closer to the history-I'm talking about history as fact.

DEL PINO: Even though your film is meant for any audience, I get the feeling from you that at root you remain-in a positive sense-with the audience of Ayacucho.

ORTEGA: In some way that's there, though perhaps not at a conscious level.

DEL PINO: Concerning your evolution, first came God Is Late but Does Not Forget, where the subject of the violence is present, but isn't the central theme. Yet, you told me that in that trilogy the topic of the violence is indeed addressed directly. How different is that first trilogy from The Innocents' Corner?

ORTEGA: They're two distinct visions. One is a story from the rural perspective in which a family is both violated by soldiers and subjected to the Shining Path; a family of humble origin. In the second case, in The Innocents' Corner, it is an urban family in Huamanga.

DEL PINO: In the second stage of your career, Incest in the Andes and The Curse of the Qarqachas deal with subject matter that turns away from the theme of the conflict.

ORTEGA: Completely, though they nevertheless occasionally invoke the history and atmosphere of terrorism. In The Curse of the Qarqachas II, two guys appear in a community. And from the point of their arrival, people start dying. What happens is the Qarqacha had followed these two guys. Then the inhabitants assume these two are causing the deaths, that they're terrorists. And so the people say they are terrorists and they are killing people. Thus, in every way we connect to the atmosphere of the [years of] violence.

DEL PINO: Speaking of people's reactions, of your films' reception, have you 
seen a difference between the reception given to more social topics that give accounts of the violence like The Innocents' Corner and people's reception of, for example, The Curse of the Qarqachas? I don't know if you've noted any difference in people's reactions?

ORTEGA: Yes. There are two things. The films on social matters, on terrorism, definitely have an audience distinct from the audience [that saw] Qarqacha. I've noticed that the social-interest films are seen by city folk. I see teachers, professors, judges, educated people. But Qarqacha has a reliable audience in the periphery, primarily in peasant communities. The numbers are almost the same. The difference is in the type of viewer.

DEL PINO: It's interesting to hear that the subject of the [years of] violence has been more captivating for an urban audience. Is this because the film takes place in an urban setting, or because people in the countryside don't want to remember and to see it again in film, or how do you understand this difference? Given that people in the countryside lived through similar or sometimes even worse repression, why didn't they go see the film?

ORTEGA: I suspect it was an issue of publicity. That could have been part of it. With Qarqacha, we directed the film more toward the countryside, with actors who spoke with more traces of the rural accent, and we advertised it that way. For rural people, between Qarqacha and The Innocents' Corner, Qarqacha's the obvious choice. It's a topic that relates to their lives. That enables a direct communication.

In my films, there are common elements that let you recognize that this is a film by Palito Ortega; I try to use regional music, music from the religious culture of Ayacucho, which is often unreleased, but which we fuse with Western [broadly popular] elements to make it more accessible in the films.

DEL PINO: Does the music also convey something about the experience of the violence?

ORTEGA: Music is an extremely important element in these stories . . . it's a central aspect. Without music the film would have had maybe 70 percent of its capacity to make the story seen or believed.

DEL PINO: So the fidelity of the story, conveyed through the use of the boy, also works in tandem with the music? 
ORTEga: The aural elements, for example the gunfire, the bombs, all these things make of the film a cohesive whole.

DEL PINO: How do you create those sounds, considering the technological limitations of our region?

ORTEga: There are now no limitations, starting with The Innocents' Corner project, which saw a great input of money. The limitations have been left behind, though at any rate there is a limit because we can't compete with people who have enormous millions of dollars of financing.

\section{Notes}

1. Interview October 6, 2008, Ayacucho. Original transcripts provided by Ponciano del Pino. Translation by Katherine Saunders-Hastings and Cynthia E. Milton.

2. The mythical figures of Pishtaco and Qarqacha (or Jarjacha in Ortega's films) are Andean mythological figures that may serve as metaphors for the violence in Ayacucho. Pishtaco (Nakaq in Quechua) is a being suspected of extracting and trafficking in human fat. Qarqacha is an incestuous human being who transforms into an animal at night. See Degregori, "Entre los fuegos de Sendero y el Ejército" and Weismantel, Cholas and Pishtacos. 

PART THREE / PERFORMING A FRACTURED PAST 


ay 21 is a date laden with meaning for the residents of the town and region of Sacsamarca, in the department of Ayacucho. It was in a battle on this day in 1983 that some residents of Sacsamarca and a few police officers defeated a contingent of Shining Path who had planned to attack the town. According to the Final Report of the Comisión de la Verdad y Reconciliación (Truth and Reconciliation Commission; CVR), it was the first successful effort by highland peoples to stem the tide of Shining Path, and thus the beginning of what grew into large-scale resistance. Because of this event, and Sacsamarca's important place in the trajectory of the internal war, this day and town are symbolic of the state's eventual victory over Shining Path. For the CVR, this date and place are representative of highland resistance. Yet, for the town's people, this date and its interpretation are continually shifting. In the wake of the CVR and in the midst of national discussions over reparations to the victims of the internal conflict, members of Sacsamarca's human rights groups with local participants staged performances and contests to commemorate May 21 and to pay homage to the residents of the town who died in the years of armed conflict. Through a study of these commemorative periods in 2003, 2004, and 2007, divergent meanings and uses of this day come to the foreground as different local actors have advanced their own agendas with regard to the past. ${ }^{1}$

The Events of May 21, 1983

Sacsamarca, the district capital, together with the towns of Lucanamarca and Sancos, the capital of Huanca Sancos province, were part of what Shining Path's Principal Regional Committee considered in 1982 as the "liberated zones," or 
regions where Shining Path held control. By 1982, Shining Path had taken over these towns with the help of some local schoolteachers who were also Sendero militants; they expelled public authorities and subjected the rest of the population to fear and coercion. After Shining Path launched its war against the Peruvian state in 1980 by burning election urns in Chuschi, some of the region's community members participated voluntarily in the new Shining Path order: students, peasants, schoolteachers, and community leaders. During the initial period of Shining Path presence, authorities were assassinated and punitive levies imposed on dissident townspeople. Nevertheless, as explained in the CVR's Final Report, the context that permitted the ascendancy of Sendero agents in this area between October 1982 and February 1983 unraveled as the inhabitants became cognizant of the quotidian disadvantages and tremendous insecurity inflicted by the imposed regime. ${ }^{2}$

Discontent grew throughout the province until resistance broke into outright rebellion against Shining Path. The first act of this rebellion occurred in Sacsamarca in mid-February 1983. The townspeople of Sacsamarca (Sacsamarquinos) took advantage of Shining Path's lax control during carnival season to ambush two local Sendero commanders who were drunk at the festivities and kill them. However, Sacsamarquinos were unprepared for Shining Path's subsequent retaliation. Shining Path insurgents captured a group of Sacsamarca residents, took them to the neighboring town of Sancos, and held them there for several days awaiting the arrival of a Sendero commander for their execution. Alerted by some Sacsamarquinos, the army intervened: they mounted an indiscriminate attack on Sancos, killing both Shining Path militants and townspeople, yet freeing the prisoners.

Episodes of rebellion spread: residents in nearby Lucanamarca and Sancos soon followed suit, killing their local Sendero commanders. Shining Path sought revenge, killing sixty-seven peasants in Lucanamarca. On May 21, Shining Path attempted a similar attack on Sacsamarca. Fortunately, Sacsamarquinos caught wind of the planned attack. With the help of three police officers who happened to be passing through the area, they confronted the Sendero contingent. The battle that ensued cost the lives of fifteen residents of Sacsamarca and one police officer. The battle also led to the deaths of the Shining Path commanders and 
the capture of several other insurgents who had arrived on the scene shortly after the battle had ended and were later executed by the military.

The failure of Shining Path's punitive action against Sacsamarca did not put an end to their vengeful campaign against the town's residents. On June 24, another Senderista column attacked Sancos, assassinating three police officers and eight residents. In response, the armed forces established a base in Sancos, a post for the sinchis, a special division of the police in charge of antiterrorism in Sacsamarca and in Lucanamarca. With little local support remaining and the state armed forces now installed in the region, Shining Path were unable to reclaim their territorial and political control over the region during that summer of 1983 , although they continued sporadic attacks against the population. ${ }^{3}$

Only in the last decade has it become possible to investigate and publicly debate the events of the Shining Path years. To date, the most complete story of what occurred in Sacsamarca between 1980 and 1983 is the one released by the CVR in 2003. ${ }^{4}$ The CVR's fieldwork team reports recount the local social and economic context out of which the Shining Path movement arose and narrate in detail the course of the internal armed conflict. In the same year the CVR report was published, the story La batalla (The Battle) appeared, written by the investigative journalist Gustavo Gorriti in the style of a literary chronicle. ${ }^{5}$ The Battle describes the events of the May 21 confrontation from the perspective of one police officer who intervened in the event. The Battle of May 21 is also recounted through a compilation of artworks that were submitted for the 2004 art contest in Sacsamarca as part of an event called the "Second Homage to the Victims of Political Violence" and were published in the book Rescate por la memoria, Sacsamarca (Recovery of Memory, Sacsamarca) in $2007 .{ }^{6}$

In increasingly public ways, and despite the findings of the CVR's Final Report, the different roles played by the residents of Sacsamarca and the armed forces in this battle remain contested in Sacsamarca. Looking at the contest entries in the book Rescate por la memoria, Sacsamarca, one notes the period following 1982 is filled with dramatic individual and collective memories of generalized and arbitrary violence that persist well into the 1990 o because of the ongoing presence of the military in the region. In the wake of the internal war, during the work of the CVR, and during the ongoing discussion over reparations for victims of 
the war, some memories remain censored while others are openly discussed in the affected communities. The past has become a site of deliberation on which struggles for contemporary positions of power and influence play out. Thus, the past is a spring from which arguments for legitimacy and for individual and collective identity are drawn.

Of Victims, Heroes, and Martyrs: The Tributes of May 21

During the years when the police still exercised control over the zone, between 1983 and 1998, Sacsamarca's old town plaza was remodeled under their influence: a lone cedar tree that had marked the center of town was cut down, park benches were installed, and the central square was named after the police officer who had died in the 1983 confrontation with Shining Path. The square remained this way until 1998, when the armed forces left Sacsamarca. Subsequently, the municipality remodeled and renamed the square with the date of the principal event in local memory, "May 21, 1983." A new commemorative plaque dedicated to "the martyrs of May 21, 1983," lists the names of ten Sacsamarquinos who died on that day and partially records the name of "a military man, Dueñas." 7 Thus, the remodeling of the square highlights the townspeople's collective status as protagonists in this story with a gesture to the one police officer who fell with the residents of Sacsamarca. The revamping and renaming of the square took place at the same time as changes in the plaza's public use: the region ceased to be under military rule as part of the "emergency zone" and returned to civilian rule. The square transformed into a civic space for remembrance of a single event; the date it evoked enabled the community to place its memories within the unifying plot of the nation's defeat of Shining Path, known as "the pacification." In 1998 the heroic pacification of the region was the central narrative that the government of Alberto Fujimori employed to make visible at a national level the recently rebuilt Andean towns. Likewise, in order for communities and their members to gain recognition for their role in defeating Shining Path, and to receive any reparations, they had to position themselves within the state-endorsed version of events. ${ }^{8}$ 


\section{Memory Entrepreneurs}

In 2002, the presence of CVR fieldwork teams in Sacsamarca activated processes of individual remembrance that, through the framework of the CVR, led to their contextualization within a collective experience. One such person who interpreted May 21, 1983, through the lens of the CVR is Orlando Janampa, a young resident of Sacsamarca who collaborated with regional cVR teams. As a result of his experience with the CVR, Janampa subsequently strove to create a tribute to the victims of political violence in Sacsamarca. As he himself has written, the creation of an homage to the victims allowed him to "find peace within himself and with others concerning all the events that happened in Sacsamarca," believing that "to talk about the topic of political violence" was "a way of bringing us together, the residents of Sacsamarca." Janampa, who lost his father and almost twenty relatives because of "all the events that happened," tried, in this way, to find meaning out of the past, one of "coming together and understanding," rather than remaining isolated with his fragmented and painful memories of Sacsamarca.

Inspired by his work with the CVR and his relationship with Ayacucho NGOS promoting symbolic reparations, Janampa read the CVR's Final Report in search of symbolic recognition of the victims and the collective accomplishments of Sacsamarca. He found the CVR's account of the initial instance of peasant resistance against Shining Path. With the reference of the CVR's Final Report in hand, Janampa obtained the support of the local communal assembly to organize some kind of act of symbolic reparation, even though there was no initial agreement about what form such a tribute should take. Following deliberations with members of the NGO representing those affected by the political violence (Coordinadora Distrital de Afectados por la Violencia Política), which Janampa chaired at the time, and with the support of other grassroots organizations and local authorities, the communal assembly decided that a series of commemorative acts would take place in the town square on May 20 and 21, 2003, twenty years after Shining Path's attack. Organizers invited local Sacsamarquinos and residents from neighboring towns, representatives from various regional NGOs, and the police from nearby Sancos to participate in the commemorative acts.

Events for the twenty-year commemoration of Shining Path's attack and their 


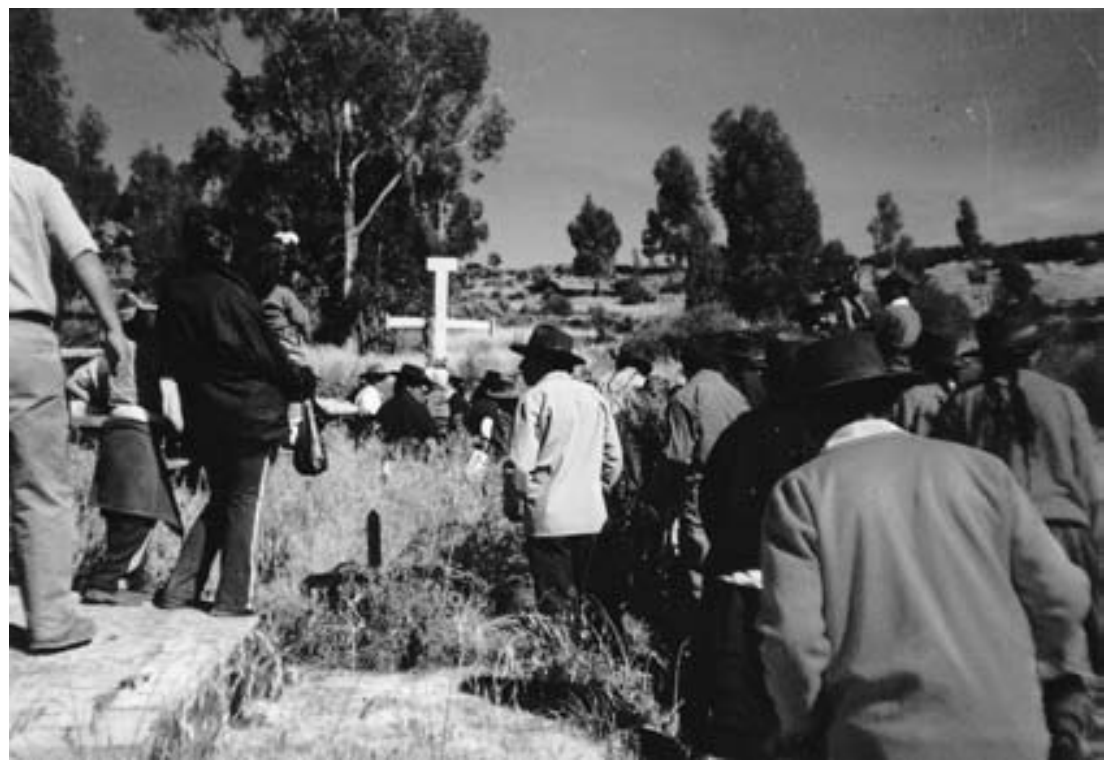

FIGURE 7.1. Pilgrimage to the cemetery in Sacsamarca as part of the "Second Homage to the Victims of Political Violence," 2004. Photograph by author.

banishment began with a rosary prayer on the night of May 20, 2003. The next day the town flags were flown at half-mast; there was a mass for all the victims, and public speeches at "May 21" square. The final act was a pilgrimage to the town cemetery, where townspeople erected a wooden cross. Organizers intended the cross to provide a memorial place for the families of the disappeared to leave their offerings for the deceased, "because," as Janampa recalls, "they had no tomb in the cemetery." ${ }^{10}$

Regional news media covered the homage. A magazine from Huamanga issued a brief feature about the event, indicating the widespread support of organizations and institutions like the Regional Front of Grassroots Organizations for Truth and Justice, the cvr-Ayacucho office, and the Peace and Hope Association, ${ }^{11}$ all of which had contributed to the tribute and had promoted it regionally. The article also gathered opinions of some residents, noting that the residents of Sacsamarca "wish to remain united and organized; [they] aspire to write their own history and memory. And in this initiative the young lead the way, thus fulfilling the obligation of those who live by honoring the memory of their heroes." 


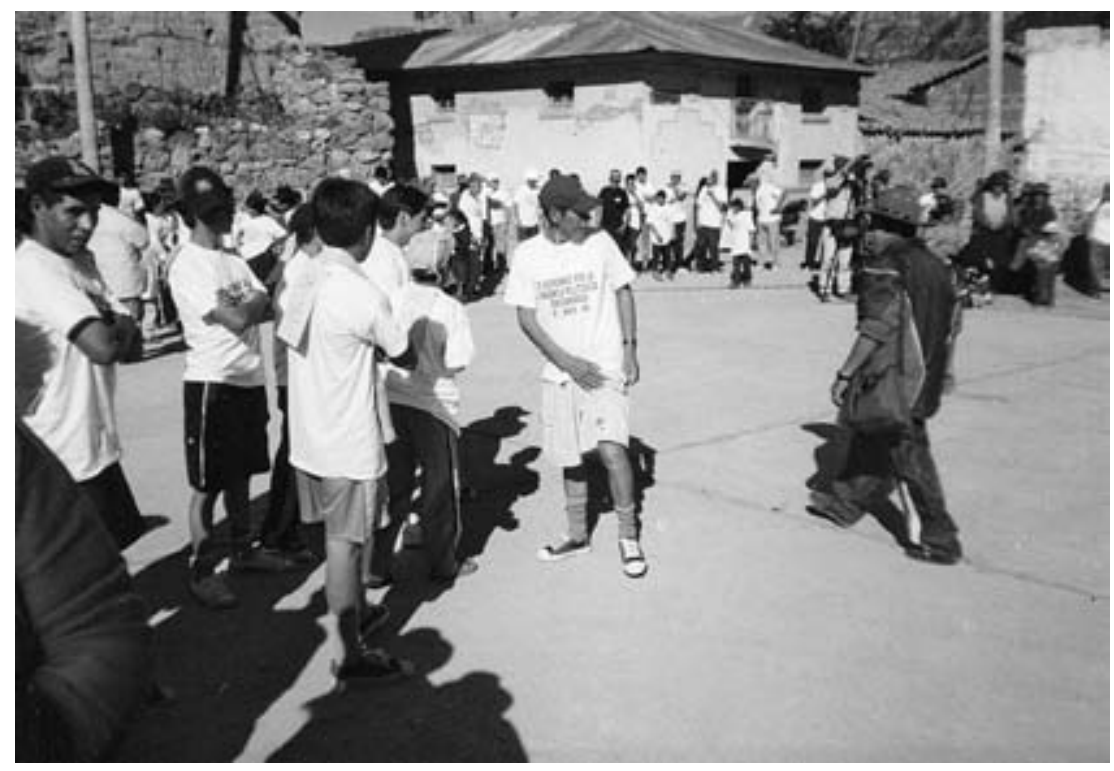

FIGURE 7.2. Marathon participants preparing for their event in the "Second Homage to the Victims of Political Violence," 2004. Photograph by author.

The article underscored the determination of Sacsamarquinos to not label their dead as victims; "they are heroes because they fought to defend their town, confronting terrorist hordes," said one interviewee.

\section{The Tribute of 2004}

One year after the first homage, the community and the Coordinadora Distrital de Afectados por la Violencia Política, together with the municipal government, mounted a second tribute to the "martyrs, victims, and heroes." For the second homage, Janampa and the team organizing the tribute hoped to build stronger consensus about the heroic meaning of May 21 for the community and about the shared memory of the residents of Sacsamarca who died, whether they had died while opposing Shining Path or had belonged to or been perceived as close to the insurgent cause. The second tribute built on the 2003 program, adding several contests (song, dance, poetry, art, and short stories), a running marathon, and a reenactment of the famous battle against Shining Path.

In 2004, the anniversary events lasted for two days and seemed well attended, 
bringing together local authorities and residents, and guests from Lima. On this second homage occasion, I visited Sacsamarca for the first time as a representative of Servicios Educativos Rurales (Rural Educational Services), an NGO dedicated to education, development, and democracy in Peru's rural regions. Representatives of other NGos based in Ayacucho and Lima, officials from the national Ombudsman's Office, a press team from the Lima cable television program Sin Rodeos, and a delegation of secondary school students from Lima, who were paired with local students, all attended the homage program. The invitees participated as judges in the singing contest and in the official ceremony of raising the flag on May 21. A mass, followed by a procession to the cemetery, closed the activities of May 21. It is worth noting that none of the official activities of 2004 included the police forces, despite the key role they had played in the events being commemorated and the civic nature of the occasion.

Of the commemorative events, the one that most struck me was the staging of the confrontation between the Sacsamarquinos and their police allies on the one side and Shining Path on the other. The performance took place in the square, in front of the municipal government's offices, and with almost all the citizenry in attendance. Two groups made up of secondary school students from Sacsamarca acted out the battle. They spoke in Quechua and Spanish, peppering the dialogue with local idioms, and including moments of parody, which made their spectacle of the war unexpectedly enjoyable to watch.

In brief, a series of vignettes made up the performance, showing the peaceful campesino life prior to the arrival of Shining Path, who came onstage wearing balaclavas and with very aggressive attitudes toward the local population. The narrative arc of the historical reenactment set up the battle as the final denouement of the Sacsamarca rebellion, staging it as the climax of the play after scenes showing Shining Path's mistreatment of the peasants and the equally abusive presence of the forces of order. All of these scenes included the character of a Shining Path woman who was dressed like a man and was portrayed differently from local peasant women. The police officers appeared fierce: they mistreated, interrogated, and threatened the peasants. Nonetheless, the peasants would later call on the police for help when they sighted Sendero militants. The ensuing battle involved everyone on stage. In the final scene, the Shining Path militants were killed in battle or executed. Right after this culminating point in 


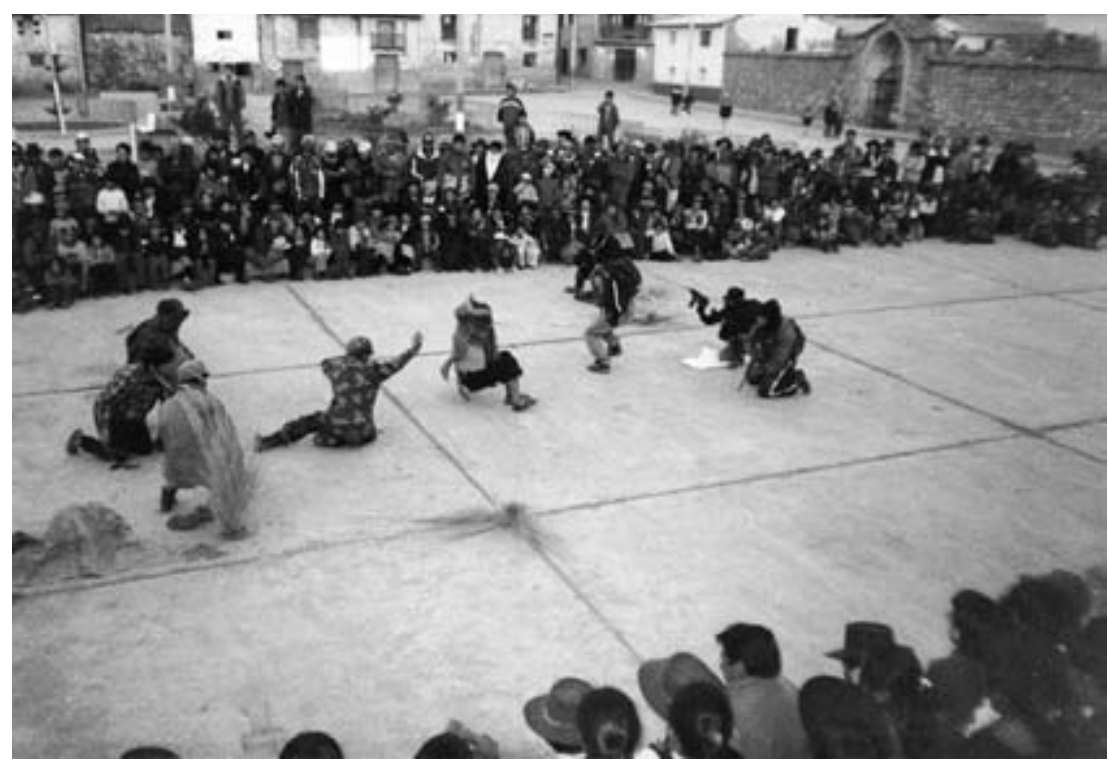

FIGURE 7.3. Reenactment scene from the routing of Shining Path from Sacsamarca during the "Second Homage to the Victims of Political Violence," 2004. Here campesinos kill the Senderistas. Photograph by author.

the performance, the actors suddenly dropped their roles and retired from the stage without changing clothes, saluting the public. Thus, they quickly passed from their acting roles as participants in a historic moment to present-day community residents.

As already mentioned, despite the play's dramatic plot, there were moments of parody that drew laughter from the audience. Humor might have eased the burden of watching this complex story, with its dramatic content so directly tied to the audience's own past and personal memories. It seemed as though humor allowed the spectators to digest the plot, and perhaps to identify themselves with what was being represented and recreated. The burlesque quality of the Shining Path characters, police officers, and peasants attenuated the evocative impact of the violent scenes. This is somewhat analogous to the use of humor in reenactments of the Spanish ambush of the Inca Atahualpa, a decisive moment in the conquest of Peru, as recorded by Huerta in a community in Cajamarca. ${ }^{12}$ But in the reenactment of the Spanish-Inca conflict, humor brings about a kind 
of reconciliation, whereby the audience, both "Spaniards" and "Indians," are eventually mixed together in dances and celebrations. In contrast, in the humor of the Sacsamarca performance, I did not perceive the same kind of carnivalesque spirit aimed at subverting or changing the dominant public history of May 21. At no point did the actors in conflict_-Shining Path militants, police, or community members - alter their position in the established hierarchy of the conflict, nor did they join each other in dance or celebration. And indeed, the humor and dramatization was not appreciated by all: the police from neighboring Sancos, who had been invited though did not attend, caught wind of how they were portrayed. As a result, one teacher was temporarily detained for having insulted the forces of order while acting in the performance. ${ }^{13}$

As for the staging of the battle, the script largely adhered to the history of the event as recorded in the CVR's Final Report. Yet the performance added certain details, such as the presence of women among the Shining Path's attacking forces, even though this was not a historically accurate portrayal of the Sacsamarca battle. The inclusion of a female Senderista does signal, however, the impact of transference between the official history of the internal war and the collective memory of the people about their specific event. The role of women among the ranks of Shining Path, including such figures as Edith Lagos in Ayacucho, was especially prominent in media coverage of the war from its earliest days, and the CVR dedicated a chapter of its report to the subject. Yet there were no female Senderistas in the battle of May 21, 1983.

The 2004 homage reached a larger audience than the previous year's had. A week after the events, $\operatorname{Sin}$ Rodeos aired an eight-minute report about the tribute. One NGO undertook to publish the works presented in the contests in poetry, narration, singing, and drawing in the book Rescate por la memoria, Sacsamarca, which they distributed free of charge in the community, in Ayacucho, and in Lima. Through these measures, the stage of these commemorative performances was amplified, permitting the tribute to reach a public far beyond the immediate region. The 2004 homage was thus able to inscribe Sacsamarquinos in the nation's telling of the conflict in a new way as protagonists, highlighting the community's role and thus downplaying the emphasis on the military and the Fujimori regime as the sole heroes in the struggle against Shining Path.

As in some other highland communities, the years of Shining Path exacerbated 
intracommunity tensions and violence. ${ }^{14}$ Such complex pasts, where categories of victim and perpetrator are not always clear or open for discussion, make reconciliation difficult. In the spirit of recognizing community tensions, Janampa and other organizers held a frustrated hope of arranging a meeting between the mayor, Teodor Herrera Pillaca, and a widow who accused him of having been involved in the death of her spouse during the early years of the armed conflict. The idea of the organizers, which the mayor apparently accepted, was to arrange a public encounter between the mayor and the widow, thus symbolizing the spirit of internal reconciliation that the homage was meant to express. The encounter did not take place; the widow did not arrive. Nevertheless, in his speech, the mayor expressed his eagerness to heal wounds and move toward progress for the town. The one-sided reconciliation resounded like one hand clapping.

No subsequent acts of homage in Sacsamarca occurred during the following two years. The aforementioned mayor took no further initiative on the matter, and Janampa's leadership seemed to wane at least temporarily, due to disputes with the community. Not even Janampa's links with institutional networks from Lima were sufficient to promote further commemorations. This inaction may reflect a more general tendency in Peru: the CvR and its Final Report, which had inspired and oriented many memory projects, fell into relative neglect as the Final Report gradually lost significance in the media and was accorded low priority on the political agenda of the Alejandro Toledo government (2001-2006), thus delaying the application of the symbolic and economic reparation measures that the truth commission had recommended.

\section{The Tribute of 2007}

In 2007, a public homage to the victims of political violence and the heroes of the May 21 battle was held once again, but in a strikingly different political context, in which renewed interest in a homage had arisen. New national and municipal governments seem to have reactivated the cause of memory in Sacsamarca, albeit with nuances that distinguished this tribute from previous commemorations. In effect, despite an ambiguous government discourse on the CVR that neither fully accepted nor rejected the findings of its Final Report, the Alianza Popular Revolucionaria Americana government headed by Alan García (2006-2011) 
implemented some of the measures the CVR recommended. Among these was the creation of the Reparations Council, a body mandated to design and produce a national registry of victims for the purpose of issuing individual reparations. The government also announced that collective reparations would be made to the most severely affected communities. The reparations plan generated expectations in the community and district of Sacsamarca. For the new mayor, Edgar Olivares, the May 21 homage was an opportunity that could potentially contribute to the recognition of the role played by the community in defeating Shining Path and thus bolster the community's chances of receiving some of the national reparations funds.

The 2007 homage once again featured a series of artistic works - though without the element of contest-as well as another reenactment of the May 21 confrontation with Senderista forces. This time, though, the organizers did not invite representatives of NGos, the Ombudsman Office, or the police. This was, however, the first tribute convened and organized by the municipality of Sacsamarca through the initiative of the mayor rather than at the behest of community organizations and individuals.

Edgar Olivares is from Sacsamarca and a contemporary of Shining Path youth. He is of the same generation as Juan López Liceras and Walter Huaccachi, the two Senderista agents who were assassinated by townspeople in February 1983, with whom he spent his childhood and school years. Olivares left Sacsamarca for several years, first studying at the University of San Cristobal de Huamanga, where he shared classrooms and experiences with Senderista students in the 1970s. In 1977, tired of his lack of educational progress in his studies at the stagnant university, he left to pursue greater opportunities in Lima. Some time after graduating, he left for Japan, where he remained for almost a decade. By the late 1990 s he had come back to Peru, and in 2004 he returned to his hometown.

According to Olivares, when he came back to Sacsamarca, he was told about the previous commemorative events, and he took note of the ongoing importance of the battle of May 21, 1983, for the town. He had made the earlier decision to move back to Sacsamarca because he had wanted to work with and help his community, even though this would mean being separated from his family, who now lived in Lima. Continuous visits back to Sacsamarca since his return to Peru permitted him to reestablish his old connections, and he eventually 
became mayor, winning the local elections in November 2006. His election as mayor came at a decisive juncture for Sacsamarca, just as the town found itself, along with hundreds of other communities, in line to benefit from the collective reparations program for populations affected by the internal conflict. Thus, his mandate having recently begun, he decided to promote awareness about the past through commemorating the anniversary of the May 21 battle. It was at this point that Servicios Educativos Rurales indicated their willingness to distribute to the townspeople of Sacsamarca free copies of the compilation of the art, poetry, and short stories that had been presented at the 2004 commemoration.

Mayor Olivares proposed to the community assembly the staging of another tribute for the coming May 20 and 21. The community assembly, however, did not want to displace a meeting already set for May 20, when other matters of communal interest would be discussed. Surprised by the lack of enthusiastic support for a two-day tribute, the mayor had no choice but to fit all the commemorative events into one day, May 21. He also invited provincial and regional authorities, but they did not attend. ${ }^{15}$

Well before the tribute, local townspeople assembled on their own to coordinate the commemorative activities. The majority of participants were women who were beneficiaries of the Juntos program, which assists the poorest families in the country. They were in the midst of their preparations when Mayor Olivares approached them and said, in Quechua, that they should abandon the idea of a reenactment of the confrontation with Shining Path. The mayor reminded the women that during the 2004 tribute the reenactment of the confrontation had caused problems, because the police from neighboring Sancos had not been pleased with the way the actors had portrayed them in the performance. Olivares thus suggested a more neutral alternative to a reenactment of the May 21 battle. "Times have changed," he said, "we don't have to remember those sad times anymore"; "we have nice things, our customs like the herranza" (a traditional musical play relating to animal husbandry).

On the day of the tribute, two performances were staged. High school students performed the first play. Despite Olivares's suggestion, the script and humor were similar to those of the previous 2004 tribute. The performance narrated the experiences of Sacsamarquinos in the midst of the terrifying Shining Path occupation, the conspiracy against the Senderista leaders, and the victory 
in the battle of May 21. Nevertheless, the students did heed part of Olivares's warning by making one important change: in their performance, the police presence had been reduced to a minimum; the police characters appeared only at the moment of the battle itself, without the scenes of dialogue and parody that had been staged in 2004. The youths' performance surprised the mayor, who later remarked that he had not expected them to perform a reenactment of the battle. For their part, the women of Juntos followed Olivares's advice. They improvised a performance of a herranza, which the audience applauded heartily but which did not bring about the laughter that the youths' performance did. Finally, the mayor declared that May 21 would be recognized as a date of commemoration, which he took upon himself to promote and carry out during his municipal mandate. Despite this promise, there were no commemorative events held the following year. By the time another commemorative act was held on the thirtieth anniversary of the battle, in May 2013, the event no longer referenced specific depictions of the battle, and seemed more like the civic parades held in most Peruvian towns each year for the national holiday, Fiestas Patrias. ${ }^{16}$

The Meanings of the Past

And, when they are not there to pursue their disputes over its meaning, the date will surely pass, slowly but inexorably, into the archive of the history of the past.—Elizabeth Jelin

As Gisela Cánepa has observed, "the politics of memory in Ayacucho appear to have become a mechanism for civic inclusion." ${ }^{17}$ Sacsamarca's commemorations lend themselves to a similar interpretation: through memory work, communities position themselves within the body politic. In Sacsamarca, battles over the meaning and interpretation of the past took (and continue to take) place in a moment of particularly high expectations for the region's development. For more than a decade, funds and policies to promote development and fight poverty have expanded and thus have empowered municipal institutions. In the post-CVR context, communities are discovering new ways to advance their recognition as political subjects in the nation-state and are gradually appropriating the CVR's message on reparations: that reparations are an obligation of the government and that reparations are a condition for securing democratic governance in this fragmented country, long disconnected from its own history. 
Why commemorate the internal war's events in Sacsamarca? By stressing a local history such as that of May 21, the people of Sacsamarca seek to repair or address the temporal rupture in their community that was brought on by the years of violence. They want to rewrite the national narrative and place themselves within the nation as citizens by affirming their role in the national epic as helping to defend against a common threat, that of Shining Path. The commemorative events of May 21 thus are part of a local effort to insert themselves within the national memory discourse of heroic salvation. The slogan of the third homage in 2007 is telling: "Sacsamarca, Cradle of Pacification in the Defense of Democracy; the Third Tribute to the Martyrs of Democracy: mass, pilgrimage, cultural events, and civic parade." The martyrdom attributed to the residents who died or disappeared during the conflict seeks to vindicate the community's role in the national narrative of pacification and democratic transition. ${ }^{18}$

Commemorative dates like May 21 in Sacsamarca fix places in time; they establish a meaning for the past that is supposedly unambiguous. Beyond highlighting the epic role fulfilled on that date, the date is taken up by the community as a support for their telling of their memories of what happened during the internal war. The recounting of local memories through commemorative events does not necessarily alter or contest dominant frameworks of memory or official narratives of the past. ${ }^{19}$ Thus, community members remember together the past that they consider their own, and they confront the past through a code or language that is intelligible to the "us" (nosotros) of a national experience. Yet these memories are not fixed: with each commemorative event new memories are produced, as other aspects are forgotten: "New memories require agreedupon omissions," or collective amnesia, as Benedict Anderson notes. ${ }^{20}$

Every commemorative act is a representation created by the participants. In sifting through what events are to be remembered, participants define what memories are permissible for the collective, and what memories with which they may openly identify, thus constructing a collective memory. In Sacsamarca, the rewriting of the community's place in the political conflict in each of the three tributes described here (2003, 2004, 2007) illustrates how a legitimizing narrative shapes a consensus about the past and Sacsamarca's role as a heroic community. Subtle alterations and elisions take place through the years: local sympathy for Shining Path is pushed aside, female Shining Path combatants 
make an ahistorical appearance, the brutality of the police and armed forces become increasingly implicit and less overt, the general state of violence is effaced with humor, and Sacsamarquinos become the central protagonists of the heroic battle. Thus, amnesia, omission, and remembering differently serve a collective convenience as a discursive compromise in this process of writing a narrative of their past. Widows remain silent while mayors speak of reconciliation and commemoration. And perhaps, as Jelin predicts, the date will eventually pass into the archive of the past. Such has been Sacsamarca's commemorative path of civic inclusion into the Peruvian nation.

\section{Notes}

1. The author had the opportunity to observe closely the commemorative events held in 2004 and 2007, first as an invited judge and later as an audience member. The author attended the thirtieth anniversary of the confrontation on May 21, 2013, after having written this chapter. This chapter was translated by Cynthia E. Milton and Katherine Saunders-Hastings.

2. CVR, Informe final, vol. 5, chap. 2.2.

3. In Sacsamarca, one of the last violent events was in 1994: the death of the provincial mayor as well as another sixteen people-soldiers and civilians-when their truck hit a landmine.

4. CVR, Informe final, vol. 5, chap. 2.2.

5. Gorriti, La batalla.

6. SER, Rescate por la memoria, Sacsamarca.

7. The name of the officer was Telésforo Dueñas. This number of martyrs differs from the fifteen who are often remembered in various entries of the Rescate por la memoria, Sacsamarca contest.

8. Degregori, La década de la antipolítica; Barrantes and Peña, "Narrativas sobre el conflicto armado interno en el Perú."

9. SER, Rescate por la memoria, Sacsamarca, 11.

10. SER, Rescate por la memoria, Sacsamarca, 11-12.

11. "Sacsamarca: Del dolor ... a la esperanza," Boletín Informativo Kawsaq, Sembrando Justicia (Ayacucho: Asociación Paz y Esperanza), 1, no. 2 (June 2003).

12. Huerta, "Incas y españoles bailando un alegre huayno."

13. Personal communication with Edgar Olivares, May 2007.

14. Del Pino and Theidon, "'Así es como vive gente.' "

15. Author's interview with Edgar Olivares, May 2007.

16. By 2013, Orlando Janampa had become the president of the community. Despite 
his prominent position and his early enthusiasm for memory work, the performances staged during the commemorative event focused only on traditional customs and did not make specific allusions to Sacsamarca's role in the political conflict. In addition to the performances, some women from various NGOs for families affected by the violence participated in the parade, carrying their organizations' banners.

17. Presentation by Gisela Cánepa of SER, Rescate por la memoria, Sacsamarca, October 12, 2005. The epigraph to this section is from Jelin, Las conmemoraciones, 51.

18. By the 2013 commemoration, residents of Sacsamarca seemed to position themselves more solidly as victims rather than martyrs or heroes, perhaps in an effort to more easily access national reparations.

19. Stern, "De la memoria suelta a la memoria emblemática," 3.

20. Gillis, Commemorations, 7. 

CHAPTER EIGHT/CYNTHIA M. GARZA

COLLIDING WITH MEMORY / GRUPO CULTURAL

YUYACHKANI'S SIN TÍTULO, TÉCNICA MIXTA

n 1971, a group of aspiring actors established a testimonial theater company that spoke to the immediate reality of their native country, Peru. Incorporating the performative traditions of Peru - such as mask-making, folkloric song and dance, Andean myths and spirituality-the group has performed in theaters, plazas, markets, and street corners all over the country. Almost forty years later, Grupo Cultural Yuyachkani is one of Latin America's most renowned and longest running theater ensembles. ${ }^{1}$ Yet the company's most significant moments might have been in the last decade, when it accompanied the Truth and Reconciliation Commission's (CVR) public hearings to collect testimonies concerning the twenty-year armed internal conflict between Shining Path and the state. One of their acciones escénicas (staged actions/interventions) produced during this time, Sin Título, Técnica Mixta (Untitled, Mixed Media) collapses the distance between audience and actor and calls on nontraditional processes for creating and performing the play. Produced in 2004, just after the publication of the CVR's Final Report, Sin Título creates a theatrical experience that encourages new ways of seeing and remembering traumatic moments in the nation's history and allows details that were previously taken for granted, during both the republican era and the recent past, to emerge within the collective social memory of Peru. ${ }^{2}$

\section{Staging Socially Engaged Theater}

Yuyachkani first took shape when the director Miguel Rubio and the actress Teresa Ralli, who at the time were part of the experimental theater group Yego, 
witnessed the events of a miners' strike in the Andean region. The play that resulted was Puño de Cobre (Fistful of Copper), and in the almost four decades that followed, the idea of creating Yuyachkani's type of socially engaged theater emerged. ${ }^{3}$ Their vision was to promote theater that would document the most pressing, immediate realities of Peru and make it easily accessible to spectators who would not normally have the knowledge of or resources to attend theater productions. To this end, in addition to the plays produced for Casa Yuyachkani, the troupe's performance and rehearsal space in Lima's Magdalena del Mar neighborhood, the troupe presents free public street performances in spaces not typically used for classical theatrical stagings - open-air markets, the steps of government buildings, even street corners.

The original collective chose the Quechua word yuyachkani (meaning both "I am thinking," and "I am remembering") 4 to represent this socially engaged theater that would navigate the complex national and ethnic identity of Peru. Although the group has always been based in Lima, reflecting on the problems of the country prompted the founders to travel and relocate to cities and towns across Peru, collecting stories and experiences that would later inform their work. During this period, many of the "Yuyas" (a nickname for members of the troupe) researched Andean and Amazonian traditions, learned Quechua, became well versed in indigenous dances and mask-making traditions, and invited feedback from the communities they visited. Gustavo Boada, who became the troupe's mask-maker in 1987, described one of these learning experiences:

In 1973 [the Yuyas] had a performance in Allpamina, a mining town. They did a piece called Puño de Cobre . . . based on a strike at a copper mine named Cobriza. The show talks about how the police killed some of the miners who had gone on strike. .. . The actors were acting in blue jeans and white T-shirts, and after the performance the miners told them that they really did like the show, but that "next time, don't forget your costumes." They thought they had forgotten their costumes because for the [Andean] miners - who are very connected with nature, and appreciate colors - mask imagery is very important for them, and dance is an equally important element. . . . This made Yuyachkani realize that they were making a very different kind of theater than what the population [of this region of Peru] 
knew. So they decided they had to figure out not only how to investigate social problems, but also how to investigate traditions, and the significance ... of those traditions. ${ }^{5}$

Boada's anecdote about costuming is important because it elucidates the Yuyas' process of embracing an Andean cosmovision in their work to reach out to a wider Peruvian audience. In this case, the miners in the Andean mining town suggested that without the costumes and masks-whether the colorful, intricate masks of the Puno region or the knitted masks of Ayacucho-this was not a complete performance.

Today it is the diversity of Peru's performative customs that are the foundation and inspiration of the group's work. Their public processions in nontraditional spaces and their performances in villages throughout the country often invite the public to join in on the performative conversation, which simultaneously celebrates Peru's national heritage and interrogates its political shortcomings. Thus, the current ensemble-Rubio, Teresa and Rebeca Ralli, Ana and Débora Correa, Augusto Casafranca, and Julián Vargas - is continuing Yuyachkani's original objective of creating a theater for the people and hence a democratic stage in a profoundly nonegalitarian society.

Yuyachkani's work harnesses their engagement with audiences and the stories culled from communities throughout Peru to call on a collective social memory that both creates and recreates the history of Peru. The Yuyas welcome the challenges of this endeavor. As Rubio has explained, Yuyachkani attempts to construct theater with "a complete consciousness of our culture and memory ... to make Peruvian theater with all of the complexity that this implies. To do that, we have to bring to theater the diversity of Peru, and there [in this diversity] we will find our identity." 6

\section{Eliciting Acciones Escénicas}

In 200o, Peru ushered in a new era of democracy and national rebuilding. One of the biggest obstacles on this path was the recent unresolved memory of the two-decade brutally violent internal war between the militarized state and Shining Path. According to the CVR's Final Report, almost seventy thousand citizens, the vast majority of them indigenous peasants, lost their lives in this war. ${ }^{7}$ The 
plays Yuyachkani produced during the Shining Path era argued that such violence was not new; rather they highlighted the long-standing systemic inequities that the Andean and Amazonian populations had suffered by calling on Andean myths, customs, and the firsthand testimonies of survivors and witnesses.

Predating the work of the truth commission, Yuyachkani staged testimonial performances that bore witness to what many in Lima feigned not to know or did not wish to know. For instance, one of the most memorable pieces addressing the years of violence was Contraelviento (Against the Wind; 1989), based on a survivor's testimony about a 1986 massacre in the highland region of Ayacucho, the impoverished Peruvian department where Shining Path was born. The story of the massacre, in which armed forces drove villagers over a cliff to their deaths, is reconfigured in this piece through the narrative structure of Andean folklore.

In one scene, for example, the devil, an angel, and the China diabla (Chinese devil), well-known characters from Andean folkloric dance, make an appearance.

Masked dancers from pre- and post-Hispanic performative traditions appear onstage and fight ferociously for influence over the peasants - dancing devils and spiteful archangels with trumpets like muskets, transformed into crazed figures of power. The archangels fight for ownership of the peasants' souls in the "danza de la diabla" or devil dance from the Fiesta de la Candelaria de Puno. These dances, performed annually for hundreds of years, tell a story as old as the Conquest, as recent as the criminal violence associated with Sendero Luminoso, the Shining Path. ${ }^{8}$

The later play Adíos Ayacucho (Farewell Ayacucho; 1990) introduced audiences in both Spanish and Quechua to the ghost of a peasant farmer (played by Augusto Casafranca) who is searching for a proper burial after being tortured, murdered, and thrown into a mass grave. When the play opens, Alfonso Cánepa has just lost his life and stands at his wake before his own flattened clothes surrounded by candles and fresh flowers. This striking scene depicts an Andean burial ritual, the pacha vela, whereby families lay out the clothes of their lost loved ones, to honor their absence and to accompany them in their initial postlife journey.

As the violence spread from the countryside to the capital city, so did the settings for Yuyachkani's productions. In No Me Toquen ese Valse (Don't Play That 
Waltz for Me; 1990), ${ }^{9}$ two dead performers return to a peña (live music venue) in Lima, a city now paralyzed by violence and destruction. The two struggle to find life-in the space, in their performance, and in their own bodies-and are not able to do so.

Their production Antígona (2000) recasts the Greek myth of Antigone in the context of Peru's continuing violence, drawing parallels between both experiences of despotic rule and the human right of proper burial. To help develop her characters for this one-woman play, Teresa Ralli invited women who had suffered loss and trauma into Casa Yuyachkani, first sharing with them the tale of Antigone and then listening to their own stories. ${ }^{10}$

In recognition of their unique success, some of the collective's political theater outreach was eventually funded by the NGO Servicios Educativos Rurales (Rural Educational Services) as part of the CvR's audiencias públicas (public hearings) scheduled throughout the countryside. ${ }^{11}$ These acciones escénicas, which took place in August and September 2001 and again when CVR's Final Report was issued in 2003, were designed to raise awareness of the truth commission's work, to honor the victims of the conflict, and "to prompt people to come forward and speak publicly to the commission without fear."

Many of the characters that were born and nurtured for each play during the CVR's mandate made appearances in public spaces, interacting with audiences and citizens who had come to share their own testimonies. The actress Ana Correa's character Rosa Cuchillo in the play of the same name (2002) searches for her disappeared son even after she herself is dead. Although primarily based on a book by Oscar Colchado Lucio, the character was also inspired by the life of Angélica Mendoza, known popularly as Mamá Angélica, whose son was kidnapped and disappeared in Ayacucho in 1983.

The character Rosa (played by Ana Correa) staged a performance at the CVR's first public hearing in Huanta, a town in the department of Ayacucho where forty-nine men and one woman were tortured and murdered by Peruvian military soldiers and thrown into a mass grave at Pucayacu. Rosa moved slowly across the public market amid the commotion of a day's shopping, dressed all in white, before mounting a stage beneath the plastic tarps typical of any other itinerant trader, farmer, cook, or artisan. A crowd gathered around her ghostly figure to hear her testimony about her lost son. By the end of the performance, 
the connection between Rosa and the audience had grown so intimate, her story so familiar to spectators, that scenes from the play took on profound meaning for both Ana (the actress playing Rosa) and the crowd. In the final scene of the play, for example, Rosa retrieved rosewater and began to sprinkle it onto the onlookers from above. This was meant to represent a ritual of flourishing and growth, and audience members began to rub the water and rose petals onto their arms and faces. Some spectators approached the stage when the play had ended to ask for some of the water to "purify" themselves further. In a similar performance during the public hearings in the entryway to Huamanga's public market, the actress remembered: "I could not stop crying while I was telling my story because I could see the 'mamitas' [other women] crying with me."12

\section{Reexamining the Nation: Sin Título, Técnica Mixta}

A search for the body-or in the case of some, a search for the absent, disappeared body-has become a key theme in Yuyachkani's more recent plays. ${ }^{13}$ In the production Sin Título, Técnica Mixta, the search enacted is not specifically for a physical body but for the collective body of memories that was inscribed on the audiences and performers throughout the two-decade crisis. The accumulation of experiences accrued in Yuyachkani's almost forty-year history-of travels throughout the country, of audiences weeping during the public testimonies, of stories heard from survivors - are exhibited in Sin Título as "an inventory" of memory. ${ }^{14}$ In addition, whereas pre-CVR performances sought out individual bodies, in the post-CVR era Yuyachkani turned its attention to the body of the nation.

Sin Título is a work of documentary theater that takes up two narratives simultaneously: the War of the Pacific (1879-1884), a war that tested the boundaries and resolve of the Peruvian nation against external aggressors, and the armed internal conflict between the Peruvian state and Shining Path (1980-200o) that brought the question of nation again to the forefront. As in other Yuyachkani productions staged in public spaces throughout the country, the narrative plays out in one common space. That is, there is no stage, no seating area for the audience, and therefore no separation between actor and spectator.

The setting is the attic of a national museum, and the audience enters through a sectioned-off hallway lined with glass exhibition cases. To the right are news- 
paper articles emblazoned with headlines about the Shining Path conflict. These lie beside portions of the CVR's Final Report and information pamphlets. Beneath one newspaper headline, a photograph shows a woman holding a picture of a disappeared family member. Tangled pieces of rope, whips, and hojotasthe sandals typical of poor Andean villagers, made out of recycled tires - rest haphazardly on top of library books. On the walls above these displays are inscribed the poignant words of Salomón Lerner Ferbes, the Peruvian philosopher and the president of the truth commission: "When memory is really alive, it does not gaze at history, it invites the creation of it. More than simply existing in any museum, where it becomes static, memory is in the air that we breathe."

Just past the glass cases on the right side of the entry hall hangs a six-foot black-and-white photographic image of the aftermath of the 1992 car bombing by Shining Path on Tarata Street in Lima's upscale Miraflores neighborhood. This blast killed forty people, destroyed almost two hundred homes and four hundred businesses, and launched a week of citywide Shining Path strikes against the Peruvian government that completely shut down Lima. This photograph of Tarata Street is perhaps one of the most widely disseminated images of the years of violence, representing a period when people in Lima were held hostage to fear and mourning.

Displayed opposite this photograph of Tarata are old and worn red and blue uniforms, muskets, medals of honor, maps, and pages pulled from history books, conjuring a war-torn country from a different time, the War of the Pacific. The parallel exhibition brings together on the same plane two disconnected moments in Peruvian history-a war against an outside aggressor that destroyed the country, and an internal conflict that brought it to its knees once again. In the stillness before the play begins, the audience has a moment to reflect back on these two accounts, to reexamine them in a new space, and to ruminate over them side by side while being given frequent reminders of the importance of memory, such as the inscribed quote from Lerner.

Around the corner is a vast dark empty space; the bleachers that usually seat the audience in front of the stage have been removed. The crowd at first roams awkwardly, uncertain of what to do and where to go. Miguel Rubio purposefully devised this format: "When the spectators enter the space, they realize that there is no place to sit, and disconcertedly, attempt to find a place to watch [the 


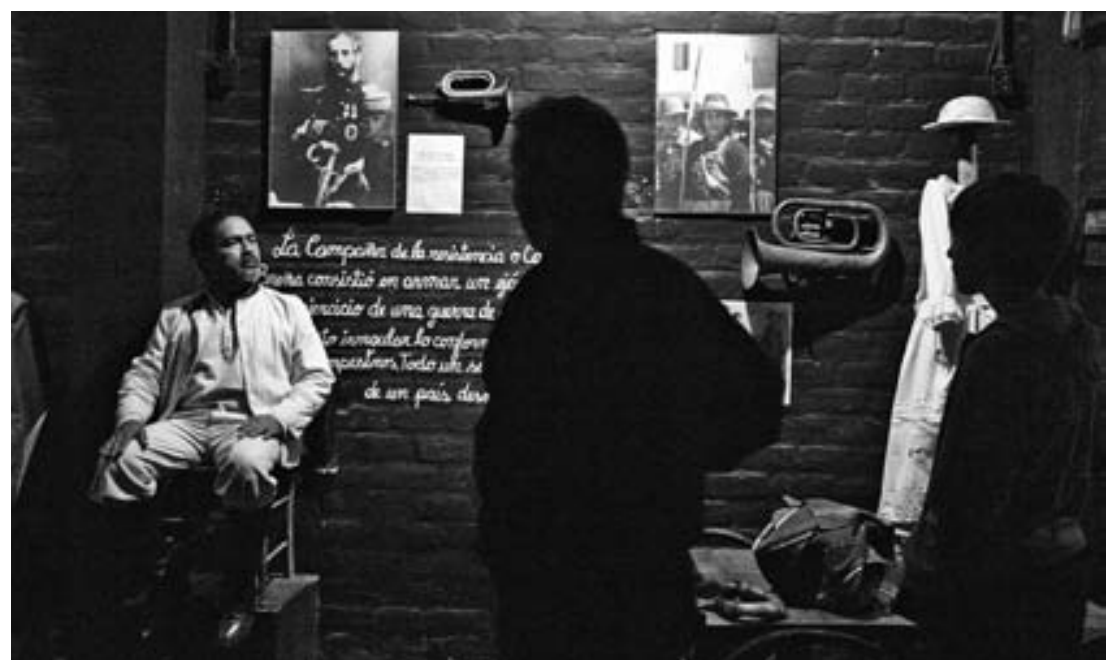

FIGURE 8.1. Yuyachkani actor Julián Vargas sits beside a series of nineteenth-century artifacts as audience members enter the performance venue and observe the museum displays in Sin Título, Técnica Mixta. Photograph by Elsa Estremadoyro.

performance]. They don't know yet that they will be able to, or that they will have to, move; they will walk around the space voluntarily or involuntarily if an actor, who they will have to make space for, passes by their side." 15

As the audience leaves the narrow hallway, they enter into this large open room, decorated by groupings of museum displays on the surrounding walls. These displays contain suits, boxes, uniforms, antique books, historical documents, photographs, mannequins, a television monitor, school desks, flags, and newspaper articles, all items common to traditional national museum displays and classrooms. An eerie accompanying music score sounds like the repeating sound of a squeaking wheel or nails being dragged slowly down a chalkboard. The crowd does not know how these artifacts will be used, what these objects mean, or why they were brought here.

Actors are positioned throughout the room, costumed to blend in with the museum displays. A man clothed in a tattered nineteenth-century Peruvian military uniform is sitting on a platform with his back to an assortment of antique brass band instruments. Above him hangs a black-and-white photograph of Andrés Avelino Cáceres, a soldier from the state of Ayacucho who became a national hero (and eventually president of Peru) for leading a resistance to 
Chilean occupation during the War of the Pacific. A veiled woman dressed in black stands proudly against the opposite wall, but her face expresses gentle anguish and sadness.

More than official museum displays, this is a holding space, an archive depository containing pieces of disturbing memorabilia. The collection, however, is still waiting to be organized into some kind of coherent order. These artifacts are intended to be handled by the audience and the actors. The play's action is driven by interactions with these objects and images that have not yet been classified by the state, by an artist, or by any arbitrating authority. The artifacts are the mixed media that make up the country's past, its incomplete "nationhood."

Soon the exhibits begin to shatter: the actors who at first stand frozen, much like wax figures in a museum, erupt from inside them and move around the open room. As the action builds, rolling platforms aggressively force startled spectators to quickly move aside and to collide (quite literally) with images, artifacts, other bodies, and words. Neither performer nor spectator stands still.

The way the audience experiences these archival pieces mirrors the processes by which Yuyachkani created the play. Over the period of a year, Rubio and the actors gathered different objects, placed them in a corner of the main room, and interacted with them, bringing the objects to life with action. These artifacts came to Casa Yuyachkani "not as props, but as evidence, testimony, necessary information ... as images that activate memory and that, at the same time, invite the spectator to choose his own point of view, to decide what he is looking at, what he hears, and where he will stop." 16

This experimental process for creating Sin Título, as Rubio described, was like "learning how to walk again," because it moved Yuyachkani away from reliance on a written script and on a narrative structure. Indeed, what the collective began to explore in the creation of Sin Título were the details about Peru's past that might emerge if the confines of conventional dramatic structure were broken. The absence of a clear narrative is often disconcerting and forces the audience to consider other connections outside chronology and place, since the action jumps across time and space.

After several minutes of audience interaction with the displays, the play proper begins in the midst of, we are to assume, the War of the Pacific. After a brief silence following the previous action of rolling platforms and collisions, the 
actors become unfrozen again and move out into the center of the room. Frantic music, the sounds of scurrying horses, doors slamming, and footsteps that become louder. The discordant back-and-forth of a violin, piano, and an occasional thunderous pounding provides the acoustic backdrop for what looks like the actors' desperate attempts to flee the scene. The actors, preparing to escape, gather suitcases, closing and opening doors, until a woman draws our attention to a man sitting in a small niche, hovering above the room, with a typewriter.

With the sounds of the man softly hammering away at his typewriter from his suspended nook, observing and recording what is transpiring, the characters below begin introducing themselves. A woman, gently caressing what looks to be a lifeless body, recounts events as they happen in the present tense:

My name is Mariana Violeta de Rodriguez. I am from Chorrillos. My husband and my sons are soldiers and are part of the reserve battalion. Today, January 13, 1881, the enemy army is attacking us from the slopes of San Juan. I run to the central plaza to see if there is news. No one knows anything. Under the dictatorship of Piérola, the newspapers are censured. Suddenly, I see hundreds of soldiers coming down the slopes. Some fall in their path. Others, bloody, ask for help. Many more run toward Lima, where they say they'll fight the final battle. Then, I see a commanding officer and ask him of the whereabouts of my husband. In response, he hands me this [she motions to the cadaver].

Next, across the room, a widow and mother of ten children proclaims that she is searching for who is to blame. "But," she asks rhetorically, "what could possibly unify our nation now?" Then she begins to play a familiar melody on her accordion-“Tacna," a song that became the anthem of heroism and nationalism all over Peru. The entire company join their voices in song:

Somos peruanos, Tacna, te adoramos, Tacna, como una enseña, Tacna, con lealtad.

Y le cantamos, Tacna, a tu bravura, Tacna, y a la hermosura de tu gran ciudad
We are Peruvians, Tacna we adore you, Tacna, like the insignia, Tacna, with loyalty.

We sing to you, Tacna, to your bravery, Tacna, and to the beauty of your great city. 


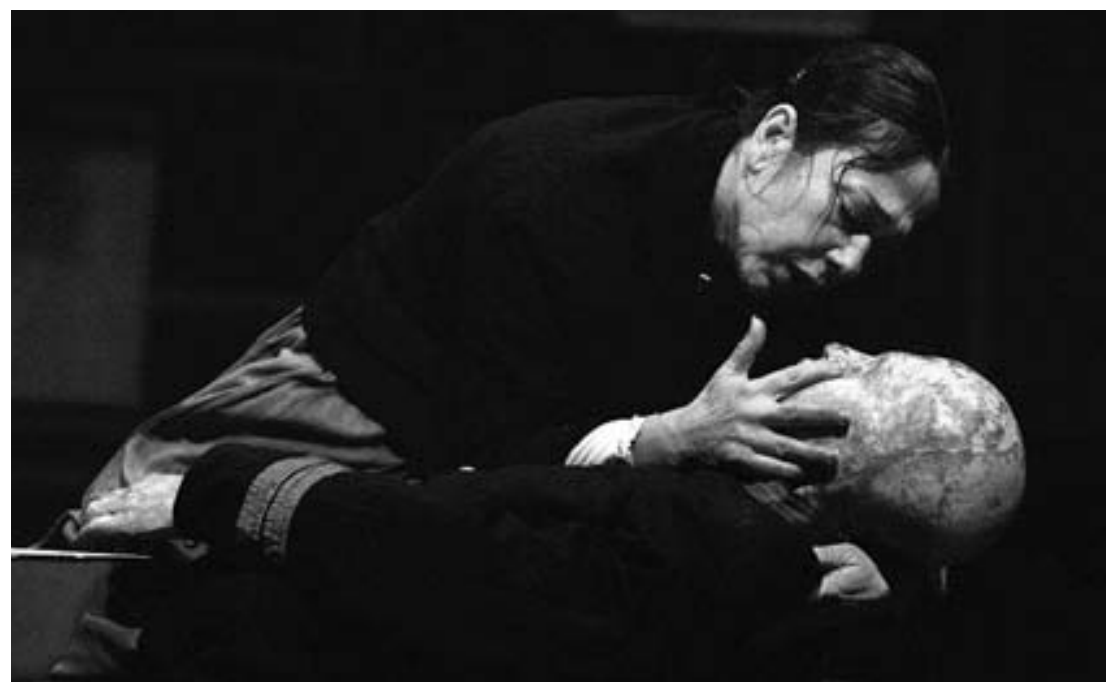

FIGURE 8.2. The actress Teresa Ralli cradling a fallen Peruvian soldier in a scene depicting a battle of the War of the Pacific. Photograph by Elsa Estremadoyro.

Tacna is the southernmost state in Peru and was under Chilean control for fifty years following the Battle of Alto de la Alianza (May 26, 1880), when hundreds of Peruvian soldiers lost their lives to defend the territory. Every year on August 28, Tacneños raise the Peruvian flag to celebrate their return to Peru at the end of the Chilean occupation. The song is most often played and danced as a lively polka, but during Sin Título it is slow and morose, and the flag being raised is tattered and torn.

The victims of the War of the Pacific, whose faces Peruvians have only seen in museums and history books, are suddenly resuscitated, over a hundred years later. Symbols that had been stripped of their history through the passage of time and by rituals of nationhood are reinscribed with stories of death and loss. The hovering writer stops typing and narrates by heart a text that concludes the play's introduction. It is an excerpt from a well-known speech delivered a few years after the conclusion of the war on July 29, 1888, by Manuel González Prada, the Peruvian philosopher and poet, from the Teatro Politeama in Lima at an event organized to commemorate Peru's independence day and to raise funds to recapture Tacna and Arica from Chilean control. In this address, he questions whether or not Peru actually exists as a nation: 
Peru suffered no greater calamity than that of the war with Chile. The campaigns for Independence and the second battle against Spain cost us precious lives and great sacrifice, but they gave us our own life, fame, and lifted our national spirit. ... Chile takes guano [bird fertilizer], nitrates, and long strips of territory, but leaves us undaunted, petty, accepting our defeat. ... Chile's brutal hand tore apart our flesh and ground our bones, but the real victors, the weapons of the enemy, were our own ignorance and our spirit of servitude . . the ignorance of our governors and the servitude of the governed. . . . Chile, with all of its meagerness, will defeat us tomorrow and always if we continue being what we were and what we are. ${ }^{17}$

The War of the Pacific for Peruvians was a collective defeat, a collective trauma that lingers in the national consciousness, even today. González Prada argued, in the address highlighted by Sin Título, that Peru was defeated by the Chileans not because Chileans were more powerful or better prepared but because Peru was a fractured nation. The speech continues with a portion of the address that sheds light on another impetus central to Sin Título: "I am speaking, gentlemen, of liberty for all, and principally for those most helpless. The 'real' Peru is not made up of the groups of creoles [descendants of Spaniards] and foreigners who populate the strip of land between the Pacific Ocean and the Andes; the nation is made up of the multitude of Indians scattered along the eastern side of the mountain range. For more than three hundred years, the Indian has crawled among the inferior stratum of civilization."

One of the central connections between these two seemingly disjointed moments in Peruvian history-the War of the Pacific and the armed internal conflict - is the oppression of the "real" citizens of the nation, those most destitute, the indigenous population. This argument continues into the next section of the play, which addresses the period of Shining Path, the Fujimori administration, and the terror that both inflicted on a nation already divided.

\section{Colliding with Memory}

After González Prada’s speech, a school bell rings loudly, drawing the audience's attention to a woman dressed in a schoolmistress uniform who sings the Peruvian national anthem in a mocking, childlike voice. She insistently points 
to dates on a chalkboard and then continues singing the anthem's chorus. She then lets down her hair and tears off her clothes to reveal a student uniform underneath. The teacher-now-student rushes into the center of the room to be indoctrinated by Shining Path.

The narrative structure up to this point — of individual actors recounting different scenes-now fractures. What follows is a whirlwind of action covering every inch of the room; one cannot see everything that is taking place. Not only are the actors all moving constantly to the accompaniment of a military brass band march, but the audience is forced to repeatedly move because actors are marching, running, rolling toward them from every angle. At the back of the room, there are small projected screens on the wall displaying Shining Path women's armies marching in prison yards, saluting the Maoist flag, and chanting. The female teacher-now-student is rolling a desk, jumping on top of it, and riding it around. The music transitions back and forth between a march and a loud electric guitar solo. Another teacher, with a wooden stick in her hand, is now marching militantly about in a dark uniform, hair pulled back in a tight bun. She repeatedly salutes, sometimes with an outstretched arm, other times with her hand to her forehead in the fashion of Shining Path militants.

A man standing on a platform at the back wall suddenly commands everyone's attention: he is the spitting image of Abimael Guzmán, the leader of Shining Path, in his black-rimmed glasses, with left hand on hip and right arm extended as if he were delivering an address to his followers. The student abandons her desk and begins to wave a massive red flag while marching frenetically and screaming, as the teacher lets down her thick black hair, covers her face with a wooden mask, and bangs out a violent rhythm on her desk with two drumsticks.

The music transitions yet again, this time into a distorted Greek wedding song. Actor Julián Vargas is reenacting what was dubbed the "Zorba the Greek" routine made famous when a video of Abimael Guzmán, snapping his fingers, was leaked to the Peruvian press. ${ }^{18}$ He snaps and shuffles and kicks, arms outstretched, cigarette dangling from his lip. While the scene is humorous, it also evokes unease at the reminder of this cruel leader's hidden dancing in the dark attic of an affluent Lima apartment years ago.

All of these images - with Guzmán's dancing as familiar as the gray Peruvian school uniform - are thrown at the audience simultaneously as reminders of a 
time that many have tried to forget. Because the action is in one common space, the spectators - who are at once drawn to the images and must also flee from them when they get too close-experience the urgency of the chaos firsthand. Moreover, the audience is almost complicit in the drama. At several points in the play, the actors point at and direct their attention to individual members of the crowd and run at them screaming.

Later, masked, mannequin-like bodies come to life, their spindly necks supporting oversized caricatured faces of Alberto Fujimori and Vladimiro Montesinos, the infamous president of Peru (1990-200o) and his head of intelligence, respectively, who became symbols of dishonor and corruption after seizing absolute power through a dense network of businesses, media, and political parties. Although the Fujimori administration is largely credited with the capture of Abimael Guzmán and the end of Shining Path's terror campaign, it is also associated with massacres, tortures, and political harassment during the internal conflict.

Fujimori and Montesinos make their appearances in Sin Título with aloof and childlike expressions. Fujimori is seated, legs crossed, pointing in an accusatory manner at members of the audience. He points at himself and then throws his palms into the air in a gesture of "Who, me?" Some audience members laugh nervously. Montesinos is kneeling, nodding, pointing, and slowly turning out his empty pockets (as if to suggest his innocence of the claims of malfeasance). All the while, circus music is playing in the background. At one point, Monopoly play money is tossed about, and some members of the audience dive for it. ${ }^{19}$

These flashes of chaos are broken by and contrasted with moments of quiet, stunning imagery. Now that the space has been fully overwhelmed with images of Peru's recent tumultuous past, it grows absolutely silent, and dark. A single rolling stage is lit, and a blindfolded woman in a white sleeveless dress stands on top. Her eyes are completely covered by a bright red crinoline cloth, and she is holding a burlap sack in her hands. Several audience members move quickly to her.

To the sound of ethereal xylophone and piano accompaniment, she begins a desperate choreography. There is clearly nothing in the sack, yet she continues to search for something. She reaches inside with her hands, her arms, and then her entire head, becoming more desperate each time she feels the emptiness 
within. For a moment, she stands with the sack on her head, evoking a scene of torture. She opens her mouth widely and screams with no sound. Then she begins to thrash around in the bag as her search becomes more frantic. Her movements are hysterical and seizure-like.

Is she the mother of a disappeared person searching fruitlessly for her son? Does she represent the nation searching for an end to the violence or searching for answers? Some audience members seem confused and wait for more to happen. Others gasp, moved to silence and tears. Again, there are no words and no narrative. This moment, this imagery is created only by gestures and the anguish displayed via the actress Teresa Ralli's body.

\section{Learning to Walk Again}

Sin Título challenges audiences to search out new ways of seeing and remembering two moments in Peruvian history. By juxtaposing the nationalistic narratives of the War of the Pacific - which take for granted the suffering of indigenous populations and ignore the enduring inequalities of a divided nation-with the internal conflict of the twentieth century, the Yuyas successfully demonstrate that the nation's most traumatic memories were, in a sense, the same mistake made twice.

The most poignant example of this argument comes in the final scene of the play, which begins with the actresses Ana and Débora Correa entering the space on separate rolling platforms. The overhead lights are off, and actors dressed as schoolchildren hold flashlights that spotlight sections of the women's bodies. Débora is clothed in a pollera, the traditional wide circular skirt of Andean women, and a hat painted in the red and white colors of the Peruvian flag. Ana is scantily clad in the feathered, beaded garments of the Asháninka peoples of the Peruvian Amazon. In a moving tribute to the women sexually and physically abused by military forces and Shining Path members during the years of violence, Ana opens up a leather cloak covering her breasts to reveal her naked body and her narrative written on the inside lining of the cloak.

In order to read the text, spectators approach the platform and lean in closely. Eventually, as others catch on, the entire crowd huddles intimately around the two women. Because the text is lit so dimly and because there are nearly a hundred people approaching the actors, the distance between audience and 
performer increasingly collapses. As Débora and Ana turn to reveal more narrative, more layers of clothing covered in words, more body parts, the story written on their bodies becomes visible.

"On Ana" is the story of a pregnant woman who lost her fetus after being kicked by Senderistas in front of her entire village. In an act that "showed the villagers what they [the Senderistas] were capable of doing," they then forced the woman to eat her aborted fetus. ${ }^{20}$ On the other side of the room, Débora opens her wide pollera as the flashlights turn to reveal another atrocity committed against indigenous women, this time by the state.

During Alberto Fujimori's second term in 1995, as part of the family planning portion of the national population law, female sterilizations were incorporated through a program of "voluntary surgical contraception.” . . . It is estimated that 300,000 Peruvian women were sterilized without their consent between 1997 and 1998. . . Many of them were indigenous campesinas, illiterate, Quechua-speaking, and of the poorest population on the Andean plateau, where women were tricked into trucks with the promise of food and other provisions. They were told that they would be taken back to their villages, that the procedure would not be painful, but it was not this way. The women were taken to medical posts lacking hygienic conditions, were not given anesthesia or medication, and had to return to their villages on foot. Many women bled to death. ${ }^{21}$

A number of audience members now cover their mouths with their hands in horror and walk away from the stages. All the while, Débora and Ana stand sternly staring ahead, bodies exposed. Eventually, as the music crescendos, the women begin to dance. Débora performs a huayno, a lively Andean dance meant for couples that in her version includes gestures of running and screaming. As she wildly spins, her pollera floats up to reveal her bare feet and strong legs. Ana stomps her own bare feet into the ground and waves her arms. Later, she is holding two sicuris - large Andean pan flutes-and poses with them as if they were guns.

The more they dance, their unsmiling faces transform into expressions of joy, and the audience members disperse around the room's space again. Suddenly the two women stop abruptly and face each other, mirroring each other's 


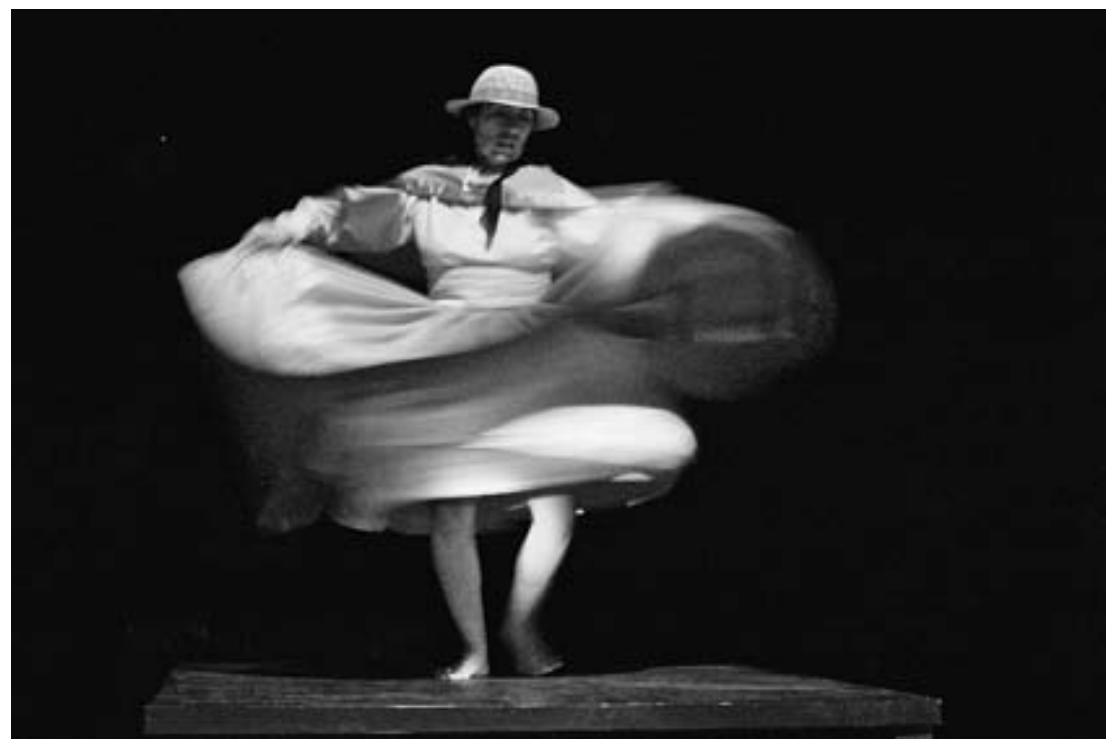

FIGURE 8.3. The text written on Débora Correa's pollera, in the colors of the Peruvian flag, is no longer visible as she dances and spins during the last scene of Sin Título, Técnica Mixta. Photograph by Elsa Estremadoyro.

outstretched hands. They are from different parts of the country and speak different languages, but this gesture, this scene, joins them in what they suffered at the hands of the government and Shining Path. They eventually step off to the side of the platforms to reincorporate themselves into the museum displays, to the sound of the ticking clock, and the lights go out. This is how Sin Título ends.

When the lights come back up, the audience has the opportunity to view again the artifacts on display, to reprocess them. These lifeless artifacts observed on entering now hold new meanings: the text written on the side wall is the same story printed on Débora's pollera in the final scene, about the maiming of woman's bodies in the Andes; a black-and-white photograph of indigenous women in bowler hats hangs beside the clothing of the mother who caressed her husband's cadaver in the opening sequence; a typewriter sits on a pedestal, pages falling from its carriage. The actors that stood among these museum displays are now gone, but their presence and what they represented lingers on.

Many of the artifacts, photographs, and texts brought to the set of Sin Título were used in previous acciones escénicas, as pieces from other plays and 
installations. Like these artifacts, the Yuyas themselves bring to the set bodies heavy with memory but not weighted down by it. In this sense, the actors themselves present evidence and testimony, rather than a character based on a script or historical narrative. What Miguel Rubio called "learning to walk again" - the process for creating the play (and the delivery of the piece itself) - allowed the Yuyas to explore the scenic mechanism of both theater and remembering in a whole new light, and fully open up these experiences to the audience. With the collection of plays addressing the internal conflict that culminated in Sin Título, Técnia Mixta, Yuyachkani’s art has transformed into a new self, a stronger body, just like the audiences and the nation they serve, ready to move into the performance spaces of a new Peru.

\section{Notes}

I would like to thank the Grupo Cultural Yuyachkani, Socorro Naveda, Tory Pegram, Diana Taylor, and the Hemispheric Institute for their participation in this chapter. Elsa Estremadoyro graciously provided the photographs.

1. Taylor, The Archive and the Repertoire, 196.

2. Yuyachkani, Sin Título, Técnica Mixta (Untitled, Mixed Media) was produced in 2004. There is no published version. All of the citations are based on the author's attendance of three performances in September 2008, and all translations here are by the author.

3. Bell, "Rediscovering Mask Performance in Peru."

4. In some regions where Quechua is spoken, yuyachkani also means "I am your memories" and "I am your thoughts."

5. Gustavo Boada, "Rediscovering Mask Performance in Peru," interview with John Bell (The Drama Review, Fall 1999), 170.

6. Ana Zwegner, "Yuyachkani: Más de treinta años," Agencia Perú, http://agenciaperu .com/cultural/tablas/especial/yuyachkani.htm, accessed June 26, 2013.

7. The CVR's Informe final estimates that of the more than 69 ,ooo victims, three of every four were Quechua-speaking campesinos.

8. Taylor, The Archive and the Repertoire, 190.

9. "No me toquen ese valse" is also the title of a famous creole waltz written by Julio Jaramillo.

10. For a fuller description of this process, see Lane, "Antígona and the Modernity of the Dead."

11. A’ness, "Resisting Amnesia," 397n. 5.

12. Discussion between Ana Correa and New York University students after performance of Rosa Cuchillo on July 25, 2005, at the Casa Yuyachkani in Lima. 
13. Rubio Zapata, El Cuerpo Ausente, 35-38.

14. Rubio Zapata, El Cuerpo Ausente, 38.

15. Rubio Zapata, El Cuerpo Ausente, 193-194.

16. Rubio Zapata, El Cuerpo Ausente, 194-195.

17. This excerpt is from Sin Título and the translation is by the author. Prada's famous speech is reproduced on several websites. For instance, www.voltairenet.org/article 120667.html, accessed July 15, 2013.

18. Available at www.youtube.com/watch?v=FEzwDx-QAqs, accessed June 26, 2013.

19. This happened in one of the three performances attended by the author, when some students from an eighth-grade class playfully went for the money when it was thrown on the floor. In subsequent performances, the actors threw the money in some audience members' faces.

20. The main source for the excerpts written on the Asháninka clothing was Ernesto de la Jara Basumbrío's "Memoria y batallas en nombre de los inocentes, Peru 19922001" (Lima: Instituto de Defensa Legal), 2001. This document is also referenced in the CVR's Informe final.

21. The Committee for the Defense of Women's Rights in Latin America and the Caribbean (Comité de América Latina y el Caribe para la Defensa de los Derechos de la Mujer) released a report in 1999, Nada personal: Reporte de derechos humanos sobre la aplicación de la anticoncepción quirúrgica en el Perú ("Nothing personal: A human rights report on the implementation of surgical sterilization in Peru"), that details nearly 250 complaints (including thirty deaths) received by the Committee since the sterilization program began in 1996. Yuyachkani employed this document, as well as testimonies collected by women's rights organizations, Movimiento Manuela Ramos, and Flora Tristan Women's Center, to piece together the narrative printed on Débora's clothing. Conversation with Ana Correa, Lima, August 5, 2005; email correspondence with Socorro Naveda, August 13, 2010. The CvR did not investigate this program. 

THE “VOICE OF THE VICTIMS”/ TESTIMONIAL SONGS

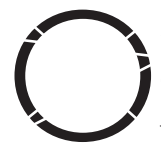

n February 20, 2002, just weeks after the Peruvian Truth and Reconciliation Commission (CVR) began its highly publicized work investigating the political violence of the 1980s and 1990s, hundreds of people gathered on the remote Waswantu plateau in Fajardo province in central Ayacucho for an annual song and dance contest dedicated to the local genre of Carnival music known as pumpin. The very first group to perform that day, the Estrellas de Fajardo (Fajardo Stars), ${ }^{1}$ opened the contest with the song "Fosas Clandestinas" (Hidden Graves): ${ }^{2}$

\begin{tabular}{|c|c|}
\hline $\begin{array}{l}\text { Qaqa mayus qaparisqa, tukusllañas } \\
\text { waqallasqa }\end{array}$ & $\begin{array}{l}\text { The chasm and the rivers shout, only the } \\
\text { owls cry }\end{array}$ \\
\hline $\begin{array}{l}\text { Llapa awqas runakuna llaqtanchikta } \\
\text { chayamuspa }\end{array}$ & All of those enemies arrived to our town \\
\hline $\begin{array}{l}\text { Metralletas y granadas runallata } \\
\text { sipillaptin }\end{array}$ & $\begin{array}{l}\text { When they killed people with machine } \\
\text { guns and grenades }\end{array}$ \\
\hline $\begin{array}{l}\text { En las fosas clandestinas llaqtaruna } \\
\text { chinkallarqa }\end{array}$ & $\begin{array}{l}\text { In the hidden graves, townspeople } \\
\text { disappeared }\end{array}$ \\
\hline $\begin{array}{l}\text { Campesinos y obreros carcelllapi } \\
\text { waqallarqa }\end{array}$ & Peasants and workers cried in prison \\
\hline $\begin{array}{l}\text { Estudiantes y maestros torturados } \\
\text { masacrados }\end{array}$ & $\begin{array}{l}\text { Students and teachers, tortured and } \\
\text { massacred }\end{array}$ \\
\hline $\begin{array}{l}\text { Mana ima quchanmanta, mana ima } \\
\text { faltanmanta }\end{array}$ & Bearing no fault, without sin \\
\hline $\begin{array}{l}\text { Llaqtaruna chinkallarqa, llaqtaruna } \\
\text { wañullarqa }\end{array}$ & Townspeople were disappeared and killed \\
\hline $\begin{array}{l}\text { En Umaro, Bellavista, Accomarca, } \\
\text { y Cayara }\end{array}$ & $\begin{array}{l}\text { In Umaro, Bellavista, Accomarca, and } \\
\text { Cayara }\end{array}$ \\
\hline
\end{tabular}


Like many other songs at the contest, "Fosas Clandestinas" seemed ripped straight from the headlines. That very week, Peruvian news outlets were flooded with images of the first mass graves in rural Ayacucho being unearthed by the CVR's forensic teams, while names of towns associated with particularly wellknown massacres, including those listed in the final lines of the song, were once again in regular circulation throughout the country. This performance in fact fit very well with the rhetoric surrounding the establishment of the CVR, which called for a long-overdue public dialogue in Peru about the years of violence and furthermore urged that special attention be given to the "voice of the victims"- a voice presented quite literally in this instance: sung in the Quechua language in the high, strident vocal style of much southern Andean indigenous music and articulating the kind of rural, marginalized perspective on the violent past that the truth commission would champion in the public sphere on a national level. ${ }^{3}$

Though opinions about the truth commission and its work were decidedly mixed in the Fajardo province, "Fosas Clandestinas" provoked little controversy that day, referencing shared experiences and commonly held local attitudes about the war for most of those in attendance. The towns singled out for mention in the song all lie within sight of the plateau, a point emphasized by the female singers, who turned to gesture toward each town as they sang its name, centering their act of remembrance within the local geography of violence and implicitly inviting audience members to recall their own vivid memories of those massacres. As evidenced by the subdued but supportive applause following each verse, many in the audience also remembered all too clearly the regular arrival of llapa awqa runakuna, "all those enemies"-whether Shining Path members or Peruvian army soldiers - in their towns throughout the 1980 s and early 1990s, bearing "machine guns and grenades" and leaving death and destruction in their wake. Even the opening line of the song, with its evocative rendering of a landscape devoid of human presence, an absence sonically marked by the bad-omen cry of an owl and the rushing sound of rivers, offered a culturally specific reference to the rapid depopulation of the area in the 1980s, when local residents fled the escalation of the violence to live as desplazados, "displaced persons," in the shantytowns surrounding the cities of Ayacucho and Lima. ${ }^{4}$ 


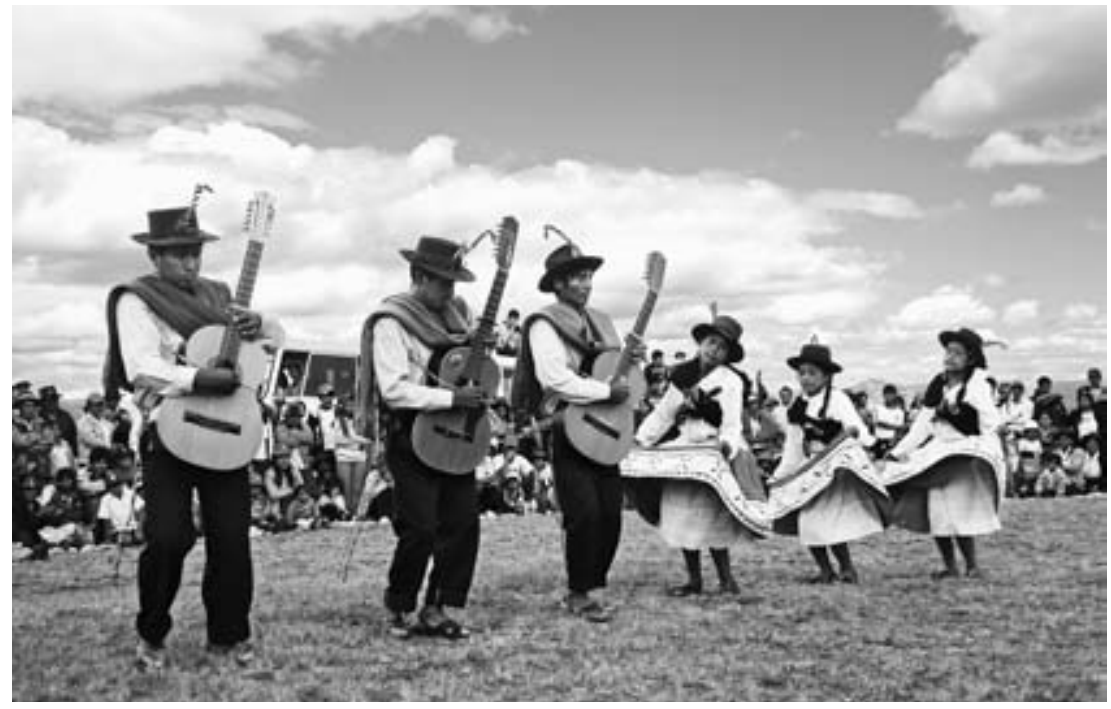

FIGURE 9.1. A contemporary pumpin group performs at the Waswantu Festival de Pumpin in February 2007. Photograph by author.

In at least one aspect, however, "Fosas Clandestinas" did not fit with the rhetoric of "rupture" and "breaking through" the fearful silences of the violent past that marked the truth commission's mandate. Far from striking any new or novel theme, the Fajardo Stars' performance fit comfortably within a well-established tradition of canciones testimoniales, or "testimonial songs," that had been performed in this genre over the previous two decades. Indeed, in both its general narrative and its specific terms and cultural references, "Fosas Clandestinas" echoed the lyrics and melodies of dozens of prior songs dating back to the mid-1980s, each lamenting the victimization of area residents, recalling prominent massacres and other violent events, and emphasizing the innocence of peasants, workers, students, and teachers. Such songs, performed at annual Carnival song contests in the province and its satellite communities in Ayacucho and Lima, and later circulated via homemade and commercial cassette recordings and videos, constitute a crucial vehicle for social commentary, remembrance, and political expression for Fajardinos (people from the province of Víctor Fajardo), opening an unusual but deeply valued social space in which 
to process and reflect on their experiences of violence throughout the long years of Peru's armed conflict.

Positioned as sites of memory, drawing on Pierre Nora's notion of selfconsciously past-oriented spaces "where memory crystallizes and secretes itself," 5 and more specifically as sounds of memory, drawing attention to the ways the past may be acoustically rendered and referenced in the present, ${ }^{6}$ testimonial songs are not, of course, sites of uniform opinion about the past or expressions of an unquestioned and static "collective memory" of a given group of people. Rather, these songs open a dynamic social space for the construction of historical narratives, a space where such narratives can be presented and transformed in the search for public consensus about the past and present. "Fosas Clandestinas" is instructive in this sense, less statement of fact than an argument for a particular way of understanding the past, marked by its own logic of what is to be remembered and, importantly, what should be forgotten. Its narrative is in fact quite selective, highlighting the violence of events associated with the Peruvian military's counterinsurgency efforts while making no mention at all of Sendero Luminoso (Shining Path), the Maoist insurgency and political organization who instigated the conflict in this region in 1980. Perhaps most surprisingly, given the emphasis placed by the CVR and other human rights workers on the need for public forums in which those affected by the violence could narrate their own stories, "Fosas Clandestinas" makes no reference to its composer's and performers' own, traumatic experiences during the war, or the reasons why they might have been more interested than others in knowing who, exactly, lay in the secret graves being unearthed by the CVR.

All of which raises a number of questions. What kind of truth(s) do canciones testimoniales tell? What voices do they represent, and from which kinds of victims? How, and by whom, are they heard, and what are the intentions of their composers? Why are such songs written at all, and what is their effectculturally, politically, otherwise? In this chapter, I approach these questions by tracing an alternate, musical history of Peru's internal war as it was experienced by people from the central Fajardo province, focusing in particular on the Carnival music known as pumpin (pronounced "poom-peen"), and the life and music of a single songwriter, the composer of "Fosas Clandestinas." This sort of person-centered ethnographic history, what anthropologist Lila Abu-Lughod has 
called an "ethnography of the particular," is, I think, necessary to unravel the complicated ways memories are conjured and (re)created in the production and performance of testimonial songs, whose potential meanings fall somewhere between the individual intentionality of their authors and/or performers and the collective expectations and experiences of their audiences. By putting the history of the internal war, an individual's lived and remembered experience of that history, and the narrative discourse of the testimonial song tradition itself into productive tension with one another, I hope to demonstrate how greater attention to cultural aspects of conflict and remembrance can expand and deepen our understanding of how this war was experienced and narrated at the local level.

Based on intensive fieldwork in Ayacucho between 2000 and 2002 and periodic visits since, this chapter joins a growing body of literature on alternate modes of truth-telling and remembrance with respect to Peru's internal war. ${ }^{8}$ Little to date has been written specifically on music and performance within this literature, despite the frequent quotation of song texts in publications about the violence, as well as music's widely acknowledged role in the expression and construction of contemporary Andean identities. ${ }^{9}$ Examining music and the context in which it was heard is especially important for understanding the years of violence in Ayacucho's central southern region, where music not only fulfilled a commemorative function after that period but also provided a crucial site of contestation throughout the conflict. In short, I contend that music and musical performance were part of how the violence itself was experienced and processed for people from this region. In that sense, this chapter also joins a growing body of literature on the broader articulations between music and violence, in which scholars have foregrounded the complex and multivalent role of music in situations of conflict, noting how it may be just as easily be utilized to incite and enact violence as to protest or remember it — or in the case of pumpin, all of these, at different times and in different places. ${ }^{10}$

\section{Pumpin and the Politics of Protest, 1976-1983}

Musicians and songwriters in Ayacucho today draw a sharp distinction between what they call canciones de protesta, "protest songs," and canciones testimoniales, "testimonial songs," when discussing music from a variety of traditional and popular genres bearing social or political content. In almost all cases, musicians 
I have spoken with prefer the latter term for their own work, reserving the former to critique songs by others that they view as overly partisan or lacking in poetic appeal. Many echo the argument made by Rodrigo, Luis, and Edwin Montoya in their seminal anthology of Quechua song texts, first published in the mid-1980s at the height of the violence: "So-called 'protest songs' . . make no sense to the men and women of Andean Peru. Political reflection appears within life, together with love, humor, agriculture, religiosity. It can't be isolated and separated from the rest." While overly utopian in its portrait of an integrated, holistic "Andean" understanding of politics, and overly dismissive of the affective potential of "so-called "protest songs"” (which they equate with politicized appropriations of Andean folklore, especially by urban university students), the position articulated by the Montoyas resonates with the diversity of themes and organic metaphors that mark most "testimonial music" in Ayacucho, including pumpin, and in fact the presence of such metaphors is often regarded as a mark of the "authenticity" of testimonial songs.

This generalized explanation, however, misses an essential reason for the rigid distinction drawn between "protest" and "testimonial" music in the Fajardo province, where the former term refers specifically to songs written in support of Shining Path or that otherwise challenge outright the legitimacy of the Peruvian government, while the latter is reserved for songs that commemorate the violence in more neutral terms or that contain what is often referred to as simply contenido social, "social content." For obvious reasons, "protest songs" are expressly prohibited in song contests today, though the gray area between forbidden "protest" and permitted "social commentary" offers grist for endless discussion and debate among performers, judges, and audience members. In the Fajardino context, the explicit rejection of "protest" songs thus reflects more than a debate over poetics or the boundaries of acceptable political discourse: it is a pointed response to the important and unusual role that pumpin music played in the initial rise of Shining Path in this region in the late 1970s and early 1980 os and the difficulties of integrating that history within the normative parameters of postviolence narratives about the war.

To explain, I turn to the biography of Roberto (a pseudonym), the composer of "Fosas Clandestinas" and longtime director of the pumpin group Fajardo Stars. Born in 1966 in a small village located on the southern banks of the Pampas 
River valley, Roberto is the eldest of four children of a local elementary schoolteacher and his campesina wife. Roberto's early life revolved around pasturing their family's small goat herd, tending his mother's fields, and, by his early teens, learning to play the twelve-string guitar in the distinctive manner that is a hallmark of pumpin music. ${ }^{12}$ Like most guitar players in the province, Roberto is self-taught as a musician, having learned to play primarily by watching and imitating older male relatives and friends, practicing on the sly with borrowed instruments until he was old enough to acquire his own. ${ }^{13}$ By his own admission, he had difficulty at first learning the necessary instrumental technique and initially had no interest in becoming a songwriter. Beyond being a pleasurable pastime in and of itself, playing guitar was simply a means of greater participation in Carnival, one of the principal annual festivities in the province.

In 1978, when Roberto was twelve, his father founded the Fajardo Stars with the intention of competing in the recently established song and dance contests, or concursos, being held during Fajardo's Carnival season. The first such contest had been held two years earlier in 1976 atop the Waswantu plateau, a broad plain high on the flanks of Mount Tinka, which towers above the region, where informal gatherings and ritual competitions of youth from neighboring villages had taken place during Carnival for generations. As Roberto and many others in the province recall today, the formalized concurso on Waswantu proved wildly popular, attracting an audience of hundreds of spectators from nearby districts, prompting the formation of dozens of competing groups and several spin-off contests in neighboring towns and quickly becoming one of the highlights of the province's annual social calendar.

As in the case of many other cultural and political initiatives in the province in the late 1970s, a widespread belief in the necessity of "progress" and "development" had motivated the establishment of the folkloric concurso. ${ }^{14}$ Its founder, a native of the region and then a student of anthropology at the Universidad Nacional de San Cristóbal de Huamanga, hoped to confer a sense of cultural legitimacy on rural traditions like pumpin through explicit comparisons with established contests for coastal genres like the vals and marinera, forms widely considered "national" folklore in Peru and associated with the criollo ("Creole," in this case indicating white and Hispanic) elite. The form, choreography, presentational style, and textual discourse of pumpin all changed radically within 
a few years of these contests' founding. The models for these changes were borrowed primarily from regional mestizo music and dance traditions and from established norms for staged folkloric presentations that dated back in Peru to the early twentieth century. ${ }^{15}$ Most notably, the meandering verses, circular dances, and improvised wit typical of Carnival ritual performances, which persist to this day in informal contexts, had given way in the concurso environment to precomposed songs on fixed themes, more elaborate musical figures, and rehearsed choreography that could be performed in a straight line before a panel of judges.

With the establishment of the pumpin contests, the changes in the thematic orientation of pumpin songs were especially dramatic. Like most Carnival music genres in the Andes, until the late 1970s pumpin verses had typically consisted of short couplets focused on themes of love and betrayal or the daily concerns of agrarian life, seasoned with an occasional dash of ribald humor or thinly veiled sexual innuendo. ${ }^{16}$ Roberto's father's first attempts at songwriting for the Fajardo Stars were typical in this regard, centering on "sentimental" topics and "songs about everyday life in the countryside," as Roberto describes them. Due in part to the judges awarding prizes to groups who made more daring thematic innovations, however, as well as the influence of regionally popular waynos, ${ }^{17}$ which at that time bore more explicit political commentary, pumpin composers soon began addressing more overtly political topics in their competition songs. Long-simmering interdistrict rivalries and disputes soon emerged as salient themes in pumpin verses, as did the turbulent national political climate of the late 1970s, including the crumbling Morales Bermudez military dictatorship, ongoing labor strife in Lima, and even Peru's border tensions with Chile.

This was also the period when Shining Path militants began organizing in this region, infiltrating local schools and holding semiclandestine meetings with area residents to prepare for the launch of their armed insurrection. Taking advantage of the unparalleled opportunity to address the large crowd, as well as the liminal moment of musical and textual experimentation opened by the concurso, Sendero militants teaching at local high schools-particularly those originally from the area and thus already familiar with the musical genre and its conventions - enlisted their students to join them in new groups to sing pumpin songs with explicitly revolutionary texts. A surviving recording of the Waswantu contest held in February 1980, one of several such recordings that area residents 
shared with me after hiding them throughout the years of violence, offers an extraordinary glimpse into Sendero Luminoso's radicalization of the event. Five of the eight songs on a 1980 recording, taped during the final round of the contest, directly address political issues, and all take a critical position with respect to the upcoming presidential elections and Peru's return to democracy after more than a decade of military rule. "Situación Internacional" (International Situation), performed by a group announced as the "Little Sirens of Waswantu," was one of several songs containing an unambiguous call for Maoist revolution: ${ }^{18}$

Pobre wakchapapas partidonchik kanmi

Pobre wakchapapas armanchikqa kansi

Partido comunista lliuchan llaqtallapi

Marxismo leninismo pensamiento Maomi

[Peru nacionllapi] Derecha, Izquierda

Altos militarwan eleccionesllawan

Democracia nispa, parlamentullawan

Apukunallaqa kamachikamuchkan

Aswan mejortaraq gobiernawananchikpaq

Guerra popularwan lucha armadawan

Guerra popularwan lucha armadawan

Obrero campesino armata hapispa

Yarqay muchuyllata puchukachisunchik
We, the poor people, will have our political party

We, the poor people, will be armed The Communist Party in every town, Marxism, Leninism, and Mao Thought

In all of Peru, the Right, the Left

The military leaders are going with elections

A parliamentary democracy, they say

The wealthy will just order us around

We'd be better off with our own

government

With a people's war, with the armed struggle

With a people's war, with the armed struggle

Worker, peasant, by taking up arms

We will overcome hunger and shortage

Written by the leader of a Shining Path cell in one of Waswantu's neighboring districts, "International Situation" is typical of many Shining Path propaganda texts of the era in its blunt reiteration of Maoist doctrine and a forceful call for armed struggle, prefiguring the discourse and militant performance style of the hymns and chants that were recorded by journalists among Senderista prisoners in the following years. ${ }^{19}$

More striking to contemporary listeners of this recording is the audience response: each verse of "International Situation" is greeted with thunderous 
applause and cheers from the assembled crowd. How to interpret this enthusiastic response? Do these pumpin contest recordings, in fact, offer proof of early support for Shining Path in this region? While the wild cheers for the guerra popular (people's war) certainly suggest that many Fajardino residents were initially receptive to Sendero Luminoso's message, closer attention to performative and sonic aspects of these recordings reveals a more complicated political environment. First, as with any musical performance, factors going well beyond song texts play an important role in generating audience responses. The boisterous cheers for armed revolution during the performance of "International Situation," for example, appear rather less convincing as evidence of widespread revolutionary fervor when heard in the context of the rest of the song; moments after its final verse, members of the audience break into an animated shouting match between the residents of neighboring towns, suggesting that crowd reaction at that moment had as much to do with interdistrict rivalries than with any particular political message. Several witty, nonpolitical song performances also elicit similarly enthusiastic crowd responses, while a different Senderista group is later subjected to boos and catcalls when its singers momentarily forget their lyrics. Unexplained moments of applause or laughter also call our attention to the presence of other aesthetic and performance factors, including choreography, dress, and even unplanned crowd behavior, all of which had an impact on audience responses.

More important from a political perspective, even if we assume that listeners were often responding primarily to the song texts themselves, the political discourse of the concurso was far from monolithic. A full review of available recordings from the early 1980 s suggests that numerous composers and performing groups in Fajardo shared Sendero's critique of the prevailing social and political order - what Gonzalo Portocarrero and Patricia Oliart have called the "critical idea" common to many rural and working-class youth of the era ${ }^{20}$-without necessarily supporting Sendero itself or its vision of armed struggle. Roberto's story and the early career of the Fajardo Stars are again instructive. In 1980, the same year several groups were making the case for Maoist rebellion, the Fajardo Stars competed in two contests with the song "Lorucha" (Little Parrot), written by Roberto's father, which cast doubt on the potential for meaningful change in 
Peru as a result of the upcoming elections and praised the Sandinista revolution in Nicaragua, which had taken place the previous year, as a potential model.

\author{
Desde Limamantas \\ Lurucha qayakamun \\ 18 mayutam elecciones nispa \\ 18 mayutam votaciones nispa \\ Chayllay elecciones pobrepa bien ninchu \\ Chayllay votaciones wakchapa bien \\ ninchu \\ Allin yachaykusqa apu favorninsi \\ Allin yachaykusqa rico favorninsi \\ Desde Nicaragua \\ Kunamuwachkanchik \\ Kay ñuqaykuqina luchaychik nispa \\ Kay ñuqaykuqina qatariychik nispa
}

From Lima

A little parrot [the mass media] is calling

There are elections on May 18, they say

There are elections on May 18 , they say

Will the poor benefit from these elections?

Will the poor benefit from the vote?

It is well known that they favor the powerful

It is well known that they favor the rich

\section{From Nicaragua}

We take our cue

Our struggle is like theirs, they say

Our awakening is like theirs, they say

These lyrics certainly expressed a Marxist position, praising the revolutionary struggle in Nicaragua and making suggestive comparisons to the situation in Peru, but in this charged context they also served as a minor statement of ideological resistance to the dominant Maoist discourse of the Senderista groups, who dismissed all other existing Marxist governments and parties as "revisionists." When I asked Roberto about this song and its relationship to the politics of that moment, he explained:

My father was a grade school teacher. His [political] tendency leaned toward socialism, something like that, but never communism. In his songs, he never put anything about armed struggle, nothing like that_-just something about socialism. ${ }^{21}$ He said that in Nicaragua they were forming a [kind of] socialism, equality between the poor and rich. That was his thinking. He always talked to me about a just society. And so, listening to the news that there had been a revolution in Nicaragua, he composed his song. The 
elections in Peru were coming up on the eighteenth of May, and [he said] perhaps there would be an unjust election, only for the powerful.

Considered together with other songs from the era that shared a critique of the Peruvian state but offered different solutions - a longing look back at the policies of the Velasco regime in the early 1970s, for instance, or more vigorous support for the country's labor and peasant movements - the pumpin concursos offer a clear illustration of both the ideological reasons behind the initial support Sendero received in this region and the limits of that support. The sheer number and variety of these songs by the early 1980 s also confirms the importance of the concurso itself as a privileged forum for political commentary: a dialogic space in which political ideas, complaints, and proposals could be presented to the largest annual gathering of people in the province.

As the war got under way, both the government's distrust of local activism and Sendero's intolerance for alternatives to its revolutionary program began to limit the possibilities for dissent. Hints of the state repression to come surfaced as early as 1980, as Roberto recalls:

Waswantu [provided] a place that was, well, free for all groups to express themselves, their problems, to denounce or reject some abuse. It was a very natural place where there was a very large gathering of people, from the different towns. I was fourteen years old, and when there were those revolutionary songs, they stayed recorded in me, those messages. Up to the point that I was scared something could happen to those performing groups, and not just the groups, but to all of us who were gathered there. There could be some kind of repression, or detention of the members of the group.

I remember very well in the year 1980, when we were in Huancapi, a group of police followed us when we were singing "Lorucha." My sister was practicing, and there was this kid who came up to the group and threw talc powder on all of the singers. ${ }^{22}$ My sister reacted furiously, giving him a few strong punches and slaps on the face. And so this kid went to the police, telling them "that group is singing against you all." My sister was detained in the commissary - one of our best singers! — and we had to go to the authorities [and beg that] they release her so she could come sing. They kept her for an 
hour before letting her out, to sing. So, there was already a fear that if you sang something, there was a possibility that you could be arrested.

Apparently undeterred by such a threat, at least at that early date in the conflict, Roberto's family returned to the Huancapi contest the following year to compete with the song "Llapa Preso" (All Those Prisoners), which protested the unjust detention of (presumably innocent) local men and women in the Ayacucho jail. ${ }^{23}$

The boldness of the Fajardo Stars' response reflects in part the retreat of the state from much of rural Ayacucho between 1980 and 1982, a move that eventually left the central Fajardo province under the virtual control of Sendero, who moved to consolidate their power in both political and cultural realms through threats and acts of violence. In February 1981, much like the year before, many songs performed at the Waswantu concurso contained explicit calls for support of the armed struggle. As Roberto recalls, echoing sentiments I heard from many others in the province, support for these groups by that point was based on a mix of factors: "At that time, I think almost everyone was with the Shining Path, out of fear or conviction - I think half out of fear and half out of conviction, for fear that they would kill you, or that something would happen to your family." Given the presence of known Senderista militants in some performing groups and the very real acts of violence that were beginning to take place as Shining Path assumed control of the region, that mixture of fear and conviction extended to the experience of the contests themselves, affecting everything from audience applause to decisions by other groups on how, and whether, to participate. One successful pumpin conjunto (performing group) director I interviewed quickly disbanded her group and moved out of the province entirely after the local Senderista leadership asked her to begin composing songs for them, while other conjuntos, like the Fajardo Stars, chose to write and perform songs emphasizing the critique of the Peruvian state that they shared with Sendero Luminoso- "Llapa Preso" is a telling example, given that many of the prisoners in Ayacucho's jail were presumed Senderista militants or sympathizers-while avoiding any potential discrepancies or disagreements they had with Shining Path's revolutionary agenda. ${ }^{24}$

Finally recognizing the role of these song contests in Sendero's campaign, 
Peruvian police forces stepped in and forcibly ended the Waswantu concurso in 1982, firing their weapons in the air and sending those present fleeing down the mountain. Ten months later, the Peruvian government declared a state of emergency in Ayacucho, placing most of the region under military control. Caught between the revolutionary zeal of the Senderistas and the scorchedearth counterinsurgency tactics of the military, Fajardinos were soon subject to extrajudicial detentions, torture, selected assassinations, disappearances, and outright massacres, all of which quickly emptied the region as people fled to the barrios of desplazados (displaced people) in Ayacucho, Ica, and Lima. The effect on pumpin was immediate and dramatic. The leaders of at least one of the principal Senderista pumpin groups discussed here were captured, tortured, and killed by the military in 1983, while former festival organizers were detained and questioned about their alleged role in "fomenting terrorism." All forms of public festivals, including Carnival concursos and patron saint fiestas, were canceled that year.

As for so many others in the province, the rapid escalation of the violence had personal consequences for Roberto. Soldiers from the Peruvian military entered his home in 1983 and took his father into custody. No explanation was offered to his family regarding why he was being apprehended, and inquiries by family members at the army garrisons in Cangallo and Huancapi during the following days and months were met with obfuscation and denial. His father, in short, had been "disappeared," one of the thousands who met a similar fate at the hands of the Peruvian military in the 1980 os. Roberto and his sisters subsequently fled to live with relatives in Lima, while his mother and youngest brother, then just ten years old, stayed to tend their crops and goats, and search in the gullies along the Pampas River where bodies of the disappeared occasionally surfaced. His father's body never reappeared, and to this day they do not know the full truth about his fate.

The following year, Roberto opted to fulfill his obligatory military service, in his own words, "to try and see what the military was doing in Ayacucho." After ten months, having "witnessed many crimes," and convinced that his father had been executed, Roberto returned to Lima. He eventually found work in Peru's informal economy as an ambulante, a street vendor, selling fruit on the streets 
of Callao. A victim and a veteran of the war, with few prospects and his family scattered, he was still only eighteen years old.

\section{The Testimonial Turn: Lima, 1984-1985}

The story of pumpin's transformation and politicization could easily have ended in 1983. The prohibition of public festivals and gatherings remained in effect for several years in most of the Ayacucho region, while the mere possession of cassette recordings of recent pumpin concursos, according to those who later shared them with me, was sufficient proof of "terrorist sympathies" to lead to arrest or worse at the hands of the military. Certainly the kind of militant discourse of songs by Sendero-affiliated groups was no longer permissible in any public forum outside the areas directly controlled by Shining Path, and in the polarized political climate, any sort of protest or questioning of the state was viewed with suspicion.

But the social space for political commentary opened by the concursos was not so easily closed, especially in an environment where many other forms of speech were so tightly controlled. In 1984, one year after the cancelation of the Waswantu contest, Fajardino migrants founded a new Carnival concurso in Lima, which was heavily attended by the newly arrived desplazado population. Within a few years contests were also established and revived in both Ayacucho and the Fajardo province. Not surprisingly, the revolutionary slogans of previous years were dropped, both for prudent reasons - the new contests were held in large public venues in urban areas with a notable police presence-and as a tacit acknowledgment that Sendero's revolutionary project had failed them. In place of odes to the armed struggle, the revived concursos were dominated by what came to be called canciones testimoniales, which initially took several forms: tragic pathos and the nostalgia of exile from a devastated homeland, commentary on the injustices and indignities of life as a desplazado in the city, and direct protest against the government and the military of real and perceived misdeeds.

It is important to acknowledge here that the revival of the pumpin contests and the testimonial turn that they took was not simply an inevitable response to the experience of political violence and refugee flight, or a natural development given the long history of social and political commentary in Andean musical 
traditions. Though the resurrection of performance traditions occurs frequently among refugee and forced migrant populations as a way of ensuring cultural continuity and providing an anchor amidst the uncertainties of everyday life, it is in no way guaranteed. ${ }^{25}$ Most other rural song traditions from the Ayacucho region, for instance, did not undergo a similar renaissance or take on the same testimonial role that pumpin did in any sustained or widespread manner, and the fear of persecution limited participation initially even among Fajardinos. Why, then, the pumpin revival and subsequent testimonial turn? Elizabeth Jelin's work on memory in postconflict societies is useful here for thinking about the role played by individuals and institutions in promoting remembrance. Jelin emphasizes what she terms the labor of memory, noting the presence of agency and work when "human beings are actively involved in the process of symbolic transformation and elaboration of the meanings of the past," a process that is particularly acute in contexts marked by political violence and trauma. ${ }^{26} \mathrm{Sev}-$ eral Fajardinos in the 1980s, people who, following Jelin, we might refer to as "memory entrepreneurs"-including contest organizers, community leaders, songwriters, and performers - recognized the need in their community for a social space that would allow for some kind of dialogue, testimony, and public recognition of their suffering and specifically chose the pumpin concurso as a culturally significant and resonant vehicle with which to meet that need.

The justifications for the concurso that these "memory entrepreneurs" offered were not limited to its testimonial function, however, and in fact the publicly stated reasons for the contest, as they were articulated to me much later by its organizers and attendees as well as expressed in period documents, coalesce around several other key themes that help explain the parameters within which such testimonial work could occur. First, as with virtually every folkloric music or dance contest in Peru, including the founding of the Waswantu contest less than a decade before, the new concursos had a stated objective of "preserving and promoting" Fajardino traditions, which were justifiably seen as threatened at that moment. The preservation of pumpin as a distinctive tradition within the Ayacucho region was also easily subsumed within the project of maintaining a Fajardino cultural identity in the urban migrant milieu, fitting with and benefiting from a broader resurgence at that time of regionally specific musical and cultural traditions within Lima’s Andean provinciano ("provincial") community, 
a movement whose origins predated the outbreak of violence. ${ }^{27}$ The rhetoric of cultural preservation and the maintenance of tradition was also encouraged by the availability of funding and support from the National Institute of Culture, which assisted in organizing the first concursos in Lima. Established discourses on folklore and cultural conservation thus dovetailed with, and provided some justification and cover for, the urgent issues of cultural survival and political dialogue facing Fajardinos at that critical juncture.

On a symbolic level, concursos also represented a conquest, or at minimum a temporary appropriation, of public space in the urban environment. Like most Andean migrant events at that time, the contests were held in rented outdoor stadiums, the first year in the working-class neighborhood of San Cosme and the second in Campo de Marte, a band shell near central Lima that remains a popular venue for Andean musical performance in the city today. For provincianos living in Lima, this was an act of cultural resistance with a long history, echoing decades of struggles by Andean peoples to find a place for themselves, literally and figuratively, in the capital city in the face of rampant racism and overt discrimination. For the newly "dis-placed," facing the double challenge of generalized discrimination against highland migrants and their especially precarious status as internal refugees from the violence in the highlands, the symbolic claim on a "space" in the center of the city, however temporary, was especially powerful, as they struggled to find places to live by means of land invasions in the increasingly far-flung northern and southern sectors of the sprawling metropolis. ${ }^{28}$

Despite the foregrounding of folkloric preservation and provincial identity as principal justifications for the new pumpin contests, all evidence suggests that participants themselves immediately grasped the event's potential as a site for continued social and political commentary. Though no recording exists of the first contests in Lima in 1984 and 1985, thus limiting possibilities for performance analysis, a printed cancionero (song book) of contest entries from those years, published later by the contest organizers, provides ample proof for this argument. More than half of the twenty-seven songs included in the booklet address topics related to the political violence and/or poverty. To cite one fairly typical example, a group called the Hijos de Colca (Sons of Colca) competed in 1984 with the song entitled "Profesorapa Llakin" (Teacher's Sorrow), a lament over the abandonment of their hometown: 
Colcallaway llaqtanchispas

Mana runa kanchu

Hoyway allqollani

Tristita awllachkan

Colquinollay paysanuykuna

Qamkuna kutikusun

Amaya qonqasunchu

Kuyay llaqtanchita
In my little town of Colca

There are no people

Only dogs

Howling sadly

My Colquino, my countrymen

We will all return

We should not forget

Our beloved pueblo

The desire to "not forget" and "return" are common refrains in many songs, the latter emphasis suggesting that the songwriters and performers were primarily desplazados, those recently displaced by the war, rather than long-term residents of the capital. These themes are taken up forcefully in the fuga, or conclusion, to another entry from 1984, "I Come from Huancapi":

San Cosmechallay pampachallapis

Pares paloma yawarta waqan

Amaya waqaychu amaya llakiychu

Kuskachallanchikmi ripukullasum

Ima palomaraq mana waqanmanchu

Waswantullanta yuyarillaspa

Amaya waqaychu amaya llakiychu

Kuskachallanchikmi ripukullasum
On the field of San Cosme

A pair of doves weep blood ${ }^{29}$

Don't cry, don't suffer

Together we will return

What dove could not cry

Remembering Waswantu?

Don't cry, don't suffer

Together we will return

Nostalgia for the life in the countryside was endemic. In "Huancapinutam" (To a Huancapino), a song from the 1985 contest also by a group from Colca, remembrance is directed at musical customs and the concurso performance itself is positioned as an act of memory.
Yuyachkankichu yuyallachkanin huancapino
Waswantullay patallapi tususqanchita
Waswantullay patallapi takisqanchisqa
Chaychallata yuyaykuspa cayarino
Campo de Martipi
Tusuykullasun takiykullasun

Do you remember as I do, Huancapino

When we danced on my Waswantu

When we sang on my Waswantu

Remembering like that, Cayarino

Here in the Campo de Marte

We will dance and sing

The appeals for remembrance and provincial solidarity-the singer from Colca calling out to those from the neighboring districts of Huancapi and Cayara 


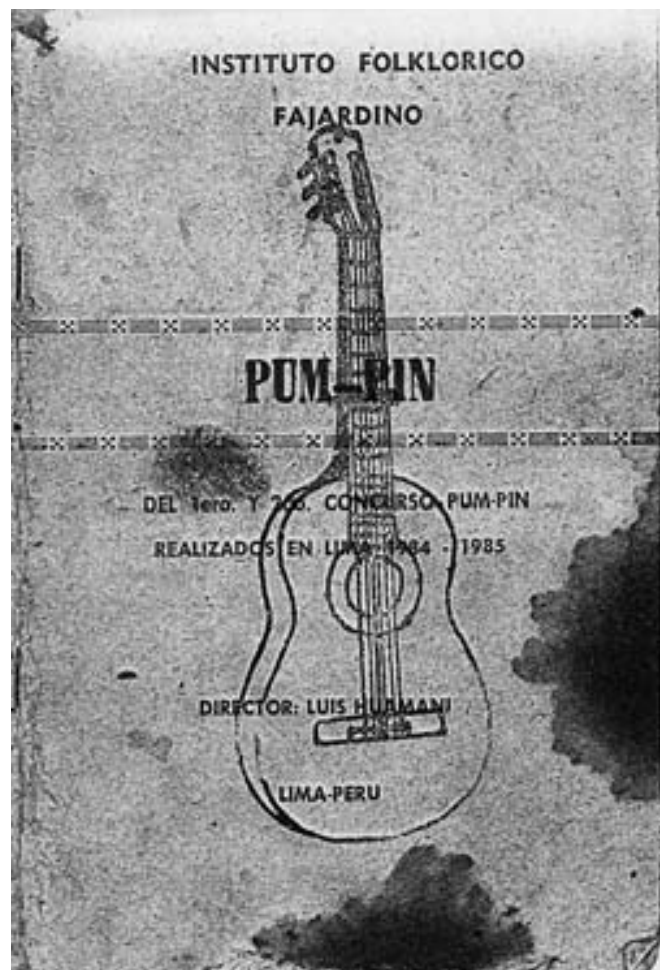

FIGURE 9.2. The front cover of a book of songs (cancionero) performed at the Lima pumpin contests in 1984-1985, published by Fajardino migrants in Lima of the Fajardino Folkloric Institute. It is very old, grainy, stained, and thus quite evocative of a difficult era and the unusual efforts made to register songs about the violence in a more permanent way.

to remember their collective experiences on the Waswantu plateau-runs through virtually all of the new testimonial songs, reinforced by frequent invocations to "my brothers and sisters" and "my fellow beloved countrymen" and anchored by references to specifically Fajardino locations, including town names and prominent geographic landmarks.

The desire for collective solidarity is also expressed in the grammar itself of most songs, which use the inclusive Quechua form of the first-person plural

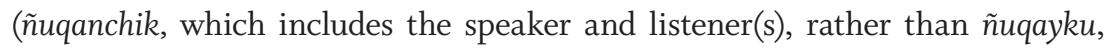
which excludes the person or people who are being addressed), thus enveloping performers and audiences in the same literal and metaphoric community of those who dance, sing, remember, and mourn together. We might interpret this in at least two different ways. As a practical matter, the use of this grammatical structure suggests that the expected audience for these songs, despite their performance at a public site in Lima, consisted primarily of fellow citizens 
from the Fajardo province, and all evidence points to this being the case. Yet, as Jelin suggests for a similar case with the Guaraní language in Paraguay, use of the "inclusive we" also constitutes an invitation to a broader audience, an attempt to find points of connection and mutual identification with others beyond one's own community, and that search for wider recognition of Fajardino suffering - the desire to be heard - was certainly a prime motivation for testimonial songwriters. ${ }^{30}$

While sadness and nostalgia were dominant themes, songwriters and performers did not avoid political topics or moderate protest. Well aware of the recent contest history in Fajardo, concurso organizers in Lima stipulated in the published rules that "protest songs" would be forbidden, hoping both to forestall potential Senderista involvement in the contest as well as to provide themselves with political cover should they be questioned about the event by the police or military. ${ }^{31}$ Nevertheless, in addition to the new testimonial songs, a number of conjuntos entered the Lima contests with songs explicitly addressing government policies, poverty, rampant inflation, and the lack of employment. The very first song in the cancionero, "Proletario" (Proletarian), the winner of the 1985 concurso, summarizes a number of these themes, bearing the class consciousness of "protest songs" from the early 1980 s but replacing the triumphalism of revolutionary struggle with an air of resigned fatalism:

Sachallamanta llaki wichisqa

Mana pipapas uqariñan llaqi

Chaynam pobrepas proletariopas

Mana pipapas yuyanallan runa

Chaynam wakchapas obrerullapas

Llapallanpapas qunqanallan runa

Qawarillayña wakllay lluqllata

Llapa causayta chincaririchin

Chaynallañataq llaqta runapas

Allillamanta chinkarillachkan

Chaynallañataq entero Peru

Allillamanta chinkarillachkan

Año 2000 chayallasunchik

Wakcha runaqa imaynaraq kanqa
Sorrow has fallen from a tree

A sorrow that no one can pick up

The same way, the poor proletariat

No one remembers them

The same way, the poor and the workers

Are forgotten by all

Look up this little avenue

All of the lives are disappearing

And just like that, the people

Are slowly disappearing

And just like that, all of Peru

Little by little is disappearing

In the year 2000

How will poor people be doing? 
Pobre runapaq wakcha runapaq

Sinchi llakillach chayaykamullachkan

Ay, que destino

Pobre kay kasyarqayllamantach

Wañullachkasunchik
For the poor people

only great suffering will arrive

Ay, what a destiny

For being poor

We are dying

While lodging a complaint against entrenched poverty and official neglect, "Proletario" positions Peru's poor, the "proletariat" of the title, as powerless to confront that reality, articulating a subject position defined by victimhood that emerged as a central theme in the testimonial song repertoire of the following decade.

A handful of composers took a more confrontational approach, more clearly echoing the political critique of songs from the early 1980s, but without the explicit calls for armed revolution. The Mensajeros de Quilla (Quilla Messengers), for instance, competed with a song directly addressing the president, performed unusually in Spanish rather than Quechua:

Señor Belaúnde escucha nuestras voces

Del Ande, de los pueblos olvidados

Año 1984, costo de vida se empeora

El salario que ganamos ya no alcanza para nada

Despertemos hermanos campesinos para reclamar nuestros derechos que nos corresponde

Ya es hora tomemos conciencia para reclamar nuestros derechos que nos corresponde.
Mr. Belaúnde, hear our voices

From the Andes, from the forgotten towns In 1984, the cost of living is getting worse The salary we earn is not enough for anything

Awaken, brothers, peasants

To reclaim our rights

That are our due

It is time to wake up

To reclaim our rights

That are our due.

Without a recording, it is difficult to gauge what the public reaction to such a song might have been. In contrast to the Waswantu contests in 1980-1982, when the line "It is time to wake up" might have generated a cheer, most of the audience members at this contest were living a nightmare brought on by such rhetoric. Not surprisingly, references to Shining Path itself or its trademark slogans are entirely absent from the songbook, an erasure that would also mark pumpin compositions throughout the remainder of the internal war (a point I will return to later). Nonetheless, the command to "rise up" or "awaken" appears 
repeatedly in other songs, a lingering echo of the genre's earlier radicalization and an indication of the continued sense of frustration and political powerlessness felt by many from the province.

The resurrection and reorientation of pumpin that occurred in Lima in 19841985, from voice of revolutionary protest to one of painful remembrance and renewed political commentary, established an enduring model for pumpin contests and songs that was adopted throughout the extended Fajardino community in the following years, as people circulated between Lima, Ayacucho, and the Fajardo province. Pumpin groups formed in the city of Ayacucho to compete in both small-scale contests organized by various district clubs as well as the larger Carnival competitions put on by the municipal government, where pumpin conjuntos developed a reputation for their especially biting and blunt political commentary and dedication to testimonial themes. ${ }^{32}$ After an absence of several years, contests also returned to the Fajardo province in the later 1980s, beginning in 1987 with a concurso in the provincial capital of Huancapi and soon spreading to other towns. Though remote sites like Waswantu remained off-limits due to the dangers posed by the ongoing conflict, by the early 1990 os pumpin concursos were held annually in all of the central districts of Fajardo, and all evidence I have gathered indicates that testimonial songs were a regular feature in all of them.

\section{The Poetics and Politics of Testimonial Songs, 1985-200o}

After the radical and rapid shifts in the political discourse of pumpin songs in the late 1970 s and early 1980 s, changes in the genre evolved more slowly during the remainder of the conflict, drawing primarily on established models for protest and testimonio already evident in the Lima contests just discussed. Despite the regular eruption of violence in the Fajardo province-including nationally newsworthy events such as the army massacres in Umaro/Bellavista (1985) and Cayara (1988), the disappearance of an entire slate of political candidates in Huancapi (1991), and dozens of smaller-scale but still lethal attacks by both the military and Sendero up through the mid-1990s ${ }^{33}$ - relatively few testimonial pumpin songs attempted to narrate or recount any of these events in detail. Rather, the testimonial repertoire was marked by the repetition and continued circulation of several broad themes that marked, and arguably helped consol- 
idate, points of consensus within the extended Fajardino community: protest against entrenched poverty; the powerlessness of campesinos as victims of violence; reflections on the landscape as a "mute witness" to human suffering; and by the late 1990s, a growing concern with national and even international political affairs, as the experience of refugee flight and return repositioned Fajardinos' sense of their place in the world.

To explore these themes, and the continued role of testimonial songs and pumpin concursos in mediating between individual and collective experiences and memories of the war, I return to the story of Roberto. After missing the first contest in Lima in 1984 while serving in the military, Roberto and several family members and friends re-formed the Fajardo Stars to compete in the 1985 Lima concurso. When I asked what he remembered of that event, he confirmed the importance of many of the themes evident in the cancionero discussed above: "Well, the songs ... [expressed] our troubles and sadness, that we had left behind our fields and our homes, that we had abandoned our families, our parents, that we had lost our families and our loved ones. We sang for them in Lima. The content was always social content, as well as political content.” Taking inspiration from his father's earlier works as well as the new testimonial discourse he encountered at the Lima contests, Roberto began writing his own songs, and he quickly took charge as musical director and principal songwriter of the Fajardo Stars. Encouraged by their successful participation in the contest in Lima, he continued rehearsing and writing for the group when he moved to Ayacucho in 1986 to begin studying agronomy at the Universidad Nacional de San Cristóbal de Huamanga, an arduous process that would take more than a decade due to frequent university closures and the precariousness of his own economic situation. Not coincidentally, this university was also a hub for testimonial wayno songwriting and performance during that period, exposing Roberto to a community of fellow students, faculty, and other activists using musical (and other) arts to reflect on the violence in the region.

It was in that environment that Roberto wrote what he refers to as his "first testimonial song," entitled "Kayllay Miseriata Puchukachisunchik" (We've Had Enough of This Misery), which merits close examination here as an illustrative example of the testimonio genre as a whole. Performed at the 1987 pumpin concurso held in Huancapi, the first to take place in the Fajardo province since the 
escalation of violence in 1983, "Kayllay Miseriata" was one of four songs Roberto wrote for the contest. In a revealing instance of how songwriters and performing groups tailor their presentations for their expected audiences, his other three entries were all songs that addressed agricultural themes and aspects of quotidian life in Fajardo, written (by his own admission) to appeal to the sponsor of the concurso, an NGO dedicated to agricultural and rural development. The strategy paid off; the Fajardo Stars won the contest, and Roberto's song "Tarpuy Yapuy" (To Plant and Plow) was declared the winning song of the event. Nonetheless, moved by the testimonial songs he had heard in Lima and Ayacucho and hoping that a song with a more current and urgent message would appeal to many in the audience, Roberto had added "Kayllay Miseriata” to the Fajardo Stars' set list. It begins with a familiar set of exhortations:

Hermanullaykuna rikcharillasunña

Paisanullaykuna qatarillasunña

Quri qullqinchikpas manañam waypanñachu

Arrozlla fideoslla rantillananchikpaq

Quri qullqinchikpas manañam waypanñachu

Chapla tantachalla kachuykunanchikpaq

Maytañach rimanchik qayakullanchikpas

Maytañach rimanchik qaparillanchikpas

Señor Presidente wakcha runakunam

Waqay waqallachkan mikuymanta nispa

Señor Presidente wakcha warmakunam

Waqay waqallachkan yarqaymanta nispa

Wakcha warmakunam waqastin purichkan

Tayta mamallanta manaña rikuspa

Verde capa loro wañurqachillaptin

Tayta mamallanta manaña rikuspa

Qanqra allqukuna sipirqapullaptin

Chayta qawaspanchik piensarillasunña Llapan campesinos cuentataqukusun
Wake up already my brothers!

Wake up already my countrymen!

Our money does not amount to enough

To buy our rice and noodles

Our money does not amount to enough

For our biscuits and bread

Where can we send our message

Where do we shout our message

Mr. President, poor people

Are crying for food, they say

Mr. President, poor children

Are crying of hunger, they say

Poor children are walking along in tears

Never to see their mothers and fathers again

When the green-caped parrots kill them

Never to see their mothers and fathers again

When the dirty dogs kill them

Seeing that, we begin to think

All peasants, we begin to say 
Kayllay miseriata puchukachisunchik

Sumaq llaqtanchikta respetachisunchik
We've had enough of this misery

Respect our beautiful town

Like most testimonial songs, "Kayllay Miseriata" recycles a number of key phrases and metaphors from prior songs. Verses 1 and 2 directly echo both Roberto's father's 1981 song "Llapa Preso" and the Quilla Messengers' song quoted earlier, demanding that fellow "brothers" and "countrymen" "wake up" and making a direct appeal to the Peruvian president to address chronic poverty and hunger, especially among children and orphans. It is worth noting that these prior songs themselves were adaptations of even earlier ones, including in this case a long tradition of waynos addressed directly at the Peruvian president, and their invocation here thus referenced layers of accrued meanings and memories for Fajardino listeners. ${ }^{34}$

On the one hand this practice of intertextuality simply reflects a longstanding and widespread tradition of borrowing, altering, and improvising with existing or well-known verses during Carnival, despite official concurso rules demanding "original content." Roberto's paraphrasing of earlier songs thus fit with traditional practices in this musical genre, while also providing him with a useful musical and textual model as he made his first attempts at songwriting. At the same time, the quick establishment in the mid-1980s of several new themes and metaphors in this set of stock phrases, what I will call a testimonio lexicon, also reflects Roberto's and other songwriters' search for a common language and vocabulary capable of expressing and reflecting on their experiences during the internal war. Successful entrants to this lexicon-phrases like the thinly disguised verde capa loro, "green-caped parrot," referring to thieving or murderous Peruvian soldiers, or endless variations on waqay (to cry), llakiy (to be in pain, sorrow), waqastin purichkan (to walk along in tears), yawar waqay (to weep blood), and the already mentioned yawar mayu (river of blood)—offered a poetic shorthand for complex and powerful memories and emotions, allowing songwriters to access and express a wide range of experiences and feelings within the relative economy of each individual song text.

Given the emphasis placed on narrating personal experience in the rhetoric of the truth commission, as well as the broader discourse on testimonio in Latin America as a manner of "speaking truth to power,"35 one of the most striking 
aspects of this and other pumpin testimonial songs is their utter lack of first-person narrative. Almost without exception, the experience of political violence is cast in collective or generalized terms, offering few details or specifics on any individual experience or atrocity. ${ }^{36}$ In "Kayllay Miseriata," Roberto and his family's own traumatic experience-the forced disappearance and presumed assassination of his father at the hands of the military and their subsequent economic hardship and dispersal as a family — is implied in the third verse about "poor children ... who will never see their mothers and fathers again" because the "green parrots" and "dirty dogs" (a frequent insult in Quechua) have killed them, but that personal connection is never made explicit. In fact, in contrast to the "inclusive we" language marking all of the other verses, these lines adopt a distanced, third-person perspective.

There are several likely reasons for this narrative shift. One is simply pragmatic and contextual: making direct accusations against the military was a risky proposition, especially when performing in a town with a military base in the midst of the war. As Roberto pointed out to me in a later conversation, insulting soldiers in Quechua as "green parrots" and "dirty dogs" was a safer alternative, and one that could still carry a strong critique and message for the concurso audience, which consisted almost entirely of local campesinos and other residents. But other reasons for the shift to the third-person perspective in this verse may bear more directly on the nature of testimonio itself. From a psychological perspective, we could interpret the shift as evidence of a traumatic break: an inability to fully narrate personal traumatic experience, with the use of the third-person perspective thus constituting an act of deflection or externalization. Roberto's reluctance to discuss the subject of his father's disappearance, even today, hints at this "unspeakability" and the continued psychological effects of this event in his life. The public nature of this performance, however, and the pattern of other songwriters I interviewed who suffered personal losses and adopted a similar narrative strategy in their own songs suggest that the tactic of casting personal experiences of violence as shared, collective ones in pumpin songs was less an individualized psychological response to trauma than a culturally appropriate way of referencing, legitimating, and working through such an experience, rooted in the collective ethos of the community and the quasiritualized context of the concurso. ${ }^{37}$ Rather than deflection or externalization, 
the distanced and/or collective narratives about political violence in testimonial songs may be understood in local terms as a form of direct engagement, an act of positioning individual experience within a value system emphasizing solidarity and the shared experience of the community as a whole.

While "Kayllay Miseriata" approaches the topic of army violence and the practice of "disappearances" in an oblique manner, it elides other topics entirely. Like nearly every testimonial pumpin song I have encountered that was performed or recorded in contests held between 1985 and 2000, "Kayllay Miseriata" avoids mentioning Shining Path altogether. I asked Roberto about this silence:

[JR] There were songs protesting abuses by the military, the government, the sinchis [a division of the national police]. But were there songs protesting against Sendero?

[R] I don't think there were any songs against Sendero. Not because there weren't abuses committed by Sendero, but these were fewer. And I also think that groups couldn't compose songs against Sendero because it would have been a lot more problematic. Because in a real short time you'd be in your grave!

[JR] It's interesting that Sendero had more power [in that sense] than the state.

[R] That's how it was. The army and the police committed abuses, perhaps illegally, but it was a legal government. The army would come, they would take your livestock, what you had to eat, and they would say "You all always give food to Sendero, so what about us?" And they would take it. If we wanted to protest, we would have to pay the consequences, the repression, or take the hits that they freely gave out. Meanwhile, Sendero was hidden. If you sang out against them, they would come in the night in their ski masks, and you knew who it was: someone who was going to kill you. So, songs against Sendero did not exist.

While this fear of Senderista reprisals undoubtedly played a major role in limiting references to Sendero Luminoso in pumpin songs, especially those performed in the Fajardo province, there were also less obvious reasons for this erasure that go unmentioned here. First and foremost, the history of Sendero's involvement with pumpin concursos in the early 1980s made songwriters and 
performers reluctant to remind listeners of the Senderista role in politicizing this song tradition. In the polarized, zero-sum politics of the violence in Peru, any reminder of the cheering crowds for revolutionary songs at pumpin contests just a few years before would have challenged the narrative of collective victimhood that most Fajardinos had embraced as the only viable subject position open to them with regard to the internal war. Any hint of prior support for the Sendero Luminoso - however conditional or partial, or removed in time- undercut that position, and risked labeling Fajardinos as "sympathizers" or "apologists" for terrorism, a dangerous label at any point and one that became a prosecutable offense under the Fujimori regime in the 199os. In a related manner, mention of Sendero also risked raising or exposing internal rifts and divisions within Fajardino communities, where many former Sendero sympathizers continued to reside, having renounced their allegiance to the Maoist party and retreated to live in a state of quiet but uneasy coexistence with their neighbors. ${ }^{38}$

Though "Kayllay Miseriata" is typical of many testimonial pumpin songs written in the Fajardo province in the late 1980s and 9os, not all songs were so explicit or pragmatic in their political engagements. Generalized references to sadness, nostalgia, and recourse to deeply held, and distinctly Andean, beliefs about the power of place also figured in many songs and tell us something about how violence, fear, and even the act of bearing witness were understood in cultural as well as political terms. Roberto's song "Pampas Mayu" (Pampas River; 1993), for instance, evokes the sense of sorrow and the cries against social injustice marking much of the testimonial repertoire but directs its appeal to the natural world and its spiritual manifestations in the sun, moon, rivers, and local mountains. Roberto specifically calls on Apu Tinka, the principal mountain deity of the region, to acknowledge their plight: "Qatun sunqu apu Tinka, qanmi taytay yachachkanki, kay pachapi kausasqayta injusticia pasasqayta" ("Big-hearted Apu Tinka, Father, you know, that in this living world, injustice occurs"). As noted, such references to places and geographic features appear frequently in testimonial songs, at times in reference to the specific location of a violent incident or to identify the performer as from a particular location but also, as here, as a way of anchoring the experience of violence within an intimately known and living landscape. As Roberto explains, references to local mountains and other geographic features in his songs draw on both of these rationales: 
The mountains that we know as Tinka, Wamaqo, and others, are witnesses to our suffering, to what has happened to the population. There in Fajardo many people did not sleep in their houses, they had to take refuge in the mountains because it was easy for the army or for Sendero to find you in your house and commit abuses. So they had to live on the slopes of the mountains, under a tree, covering themselves up. So the mountains are mute witnesses to the suffering of all of the pueblos. About Mount Rosacha in Huancapi, [for instance,] many songs say qanmi yachachkanki llaqtapa vidanta [you know the life of the pueblo], something like that.

As the anthropologist Keith Basso notes in his work on Apache narrative, place-names have the capacity "to summon forth an enormous range of mental and emotional associations - associations of time and space, of history and events, of persons and social activities, of oneself and stages in one's life," further observing that "poets and songwriters have long understood that economy of expression may enhance the quality and force of aesthetic discourse, and that place names stand ready to be exploited for this purpose." 39 The rich associative qualities of place names that Basso recognizes here made them especially powerful for testimonial songs, allowing songwriters, performers, and audience members to access and reflect on their own memories and narratives about such places, simultaneously constructing a shared narrative or "collective memory" of the local geography of violence while appealing to the spiritual power of such places to bear witness to their collective suffering.

The most referenced geographic place in the pumpin testimonial repertoire is the Waswantu plateau, a site that in the midst of the war bore a complicated set of associations and memories, functioning as a sort of metonym for the entire history of pumpin and the consequences of political violence. In 1995, thirteen years after the last contest there had ended in a hail of police bullets, that narrative began a new chapter when the Waswantu concurso was reestablished and immediately resumed its role as the annual championship contest for the pumpin genre. Reflecting more than a decade of fraught experience, the contest rules, circulated among area districts in a small pamphlet prior to the contest, stipulated that the judges "would not accept protest songs with a political or partisan tint" but encouraged participants to perform "songs based on new inspirations 
with messages related to agricultural work, the needs of the people, demands for public works, amorous sentiments, etc."-a delicately worded distinction that needed no further explanation for area residents and songwriters. ${ }^{40}$

Roberto and the Fajardo Stars, now well-known performers and frequent winners of other pumpin contests in the province, competed with the song "Festival," reflecting the complex of emotions they and many others felt about this moment of return:

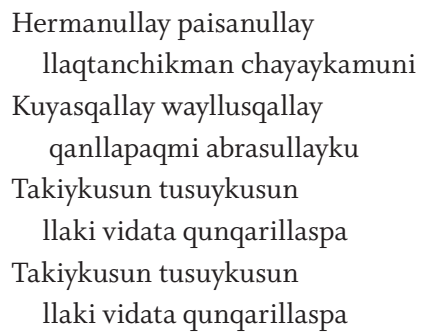

Llaqtanchikpa takiyninchik hermanullay paisanullay

Sapa wata puquy tiempo qatun qatun festivalninchik

Takiykuspa tusuykuspa llaqtanchikta kusirichisun

Takiykuspa tusuykuspa llaqtanchikta kusirichisun
Llaqtanchikpa takiyninchik hermanullay paisanullay
Sapa wata puquy tiempo qatun qatun festivalninchik
Quillaqasa patachapi Huancapillay llaqtallapi
Waswantullay patachapi pumpin taki pumpin tusuy

\author{
Brothers, fellow countrymen \\ we are arriving to our pueblo \\ Beloved friends and neighbors \\ with an affectionate greeting for all of you \\ Let us sing, let us dance \\ in order to forget our sad lives \\ Let us sing, let us dance \\ in order to forget our sad lives
}

In our town, in our song, brothers and fellow countrymen

Every year during planting season we have our big festival

Singing and dancing we make our town happy

Singing and dancing we make our town happy

In our town, in our song brothers and countrymen

Every year during planting season we have our big festival

On the Quillaqasa plain in the town of Huancapi

On the Waswantu plateau we sing and dance pumpin

The contradictory rhetorical positioning here-of singing and dancing pumpin in order to "forget our sad lives," even as many songs at the contest, and others by the same composer, commanded audiences to "remember" and confront the violence and poverty of Fajardino lives - sheds light on a key aspect of the testimonial song phenomenon in Fajardo. As Gila Flam notes in her study of the music 
of the Lodz ghetto during World War II, the juxtaposition of entertainment and social commentary is a potent one for communities who have been "purposefully restrained from pursuing a traditionally meaningful life"; music, and particularly songs, she notes, "comment and testify on the ongoing events and at the same time provide an aesthetic experience or diversion from reality." ${ }^{41}$ While many forms of testimonial arts bear this aesthetic dimension, testimonio songs and their powerful emotional messages were also, crucially, songs performed at Carnival events, which people attended to socialize, to be entertained, to sing and dance, and to be reminded of the beauty of their own cultural traditions and sense of identity as Fajardinos. Far from contradicting each other, the aesthetic pleasures of pumpin music and the testimonial messages of many songs formed a complement to one another, a mutually reinforcing narrative-especially in the context of the revived concurso on Waswantu-of cultural survival in the wake of the violence.

Though never articulating his own personal experience of the war and its consequences, Roberto's successful participation in the pumpin song contests year after year ensured that elements of his story and that of his family became part of the collective narrative that Fajardinos told, and have continued to tell, themselves about the years of violence. By the late 1990s, as peace was reestablished in the region, Roberto's songs also reflected the advent of new, postviolence concerns and discussions in the province, including topics of national and international political importance, such as the Fujimori administration's move to privatize state industries ("Wakcha Vida," 1996), the hostage crisis in the Japanese Embassy in Lima ("Embajada Japonés," 1997), and even the U.S. bombing of Iraq ("Guerra contra Irak," 1998). By 2002, when I recorded them singing "Fosas Clandestinas," the Fajardo Stars had either won or come in second place at the Waswantu contest annually for five years and had just recorded their first commercial cassette in Lima. Not coincidentally, every one of those years included at least one, and sometimes multiple, songs protesting government misdeeds, praising teachers for their sacrifices, or reflecting on the difficulties and suffering of living through the years of violence, all "truths" that not only drew on a discourse jointly developed by dozens of songwriters and pumpin groups at these concursos over many years but also were intimately linked with the story of this one individual and his family. 


\section{Conclusion}

To conclude, I return to the questions of what sort of "truths" are narrated in testimonial songs like "Fosas Clandestinas" and what could account for the rise and apparent power of this genre for processes of remembrance within the Fajardino community. The very particular story of pumpin's radicalization by Shining Path, resurrection and transformation within the desplazado community, and ultimate return to its place of origin is, as far as I know, a singular one in the panorama of Peruvian music about the internal war, and that fact has everything to do with the importance that it eventually took on as a site of memory. Indeed, as evidenced by the history sketched here, pumpin music played a crucial role in how the violence itself was experienced and processed among Fajardinos-from their disputes over Marxist ideology at the advent of the conflict to their search for common narratives as victims of the violence in later years. Memories of the performance of testimonial songs at contests in diverse locales, including Lima, Ayacucho, and at home in the Fajardo province, are consequently inseparable today from broader Fajardino memories of the internal war.

Testimonial songs also provided a key vehicle for songwriters, performers, and their audiences to mediate between individual and collective experiences and memories of the conflict. Unlike virtually all other forms of testimonial art in Peru, the principal audience for testimonial pumpin songs consisted of fellow people from the Fajardo province, and individual experiences, as demonstrated in the songs written by Roberto, were often cast in terms of that collectivity, legitimating personal experiences for those singing about them while also forging a common narrative about Fajardino victimhood. That narrative was marked as much by what it excluded - in particular Sendero's history in the region and its role in the development of pumpin music - as by what it included: laments over death, loss, and longing, expressed and framed by cultural references to a testimonial lexicon of poetic phrases and place names in a geography of violence. Testimonial songs did not, then, present a "collective memory" of the violence so much as open a social space for individuals and groups to contribute their versions of a collective past and present in the search for solidarity and consensus.

Returning to the question of "truth-telling" in pumpin music, the songs ex- 
amined here remind us that there may be more than one kind of "truth" to be told in the aftermath of violence. As Richard Wilson notes in his work on the South African Truth Commission, "truth paradigms" can at minimum be separated into two distinct categories, what he calls "forensic truth," consisting of facts and evidence, and "narrative truth," which emphasizes the personal and/or social, subjective, experiential nature of truth-telling. Postconflict societies, he argues, need both. ${ }^{42}$ Obviously, testimonial songs' contributions to the "forensic truth" about Peru's years of violence are minimal; very few testimonial songs offer specific details about events during the war, and, as noted, many important details are intentionally omitted or ignored in sung testimonial discourse. Nonetheless, the convergence of certain themes in testimonial songs year after year - the overwhelming sense of sadness and loss as a response to the violence, a deeply felt anger and even cynicism over poverty and government neglect, and the embrace of a "victim" identity for the region in the hope of securing citizen rights as sympathetic subjects - give voice to a very powerful, particular, and underacknowledged "narrative truth" of how this conflict was understood and experienced by one group of people, from the very heart of the region where it all began.

\section{Epilogue}

In November 2006, Roberto was elected a regidor provincial (provincial council member) of Fajardo province, in part due to the reputation he had developed through his success in the song contests. For the first time since 1983, he returned to live in Fajardo full-time with his growing family and assume his duties as a member of the provincial government. At the same time, his performing group, the Fajardo Stars, were forced by concurso organizers (under pressure from other conjuntos) to retire from active competition and "give others a chance." They were invited instead to continue presenting songs as a noncompeting group to entertain the crowd in between rounds of the concurso. Unable to convince his sisters to make the long trip out to the province to join him for such a presentation, Roberto was left without a group to perform with for the first time in twenty years. I found him in a small storefront off the plaza in Huancapi on the day of the event, drunk and crying. Despite the many difficulties he had endured, 
this was the only time I saw him drink to excess, and the only time I ever saw him cry. When I asked him what was upsetting him, in between demands that I join him in drowning his sorrows, he choked out that he had no one with whom to sing his songs.

\section{Notes}

I would like to thank, first and foremost, the singers and songwriters of Colca, Huancapi, Cayara, and Huancaraylla for sharing their extraordinary music and life stories with me. Thanks also to Cynthia Milton, Ponciano del Pino, Renzo Aroni Sulca, Raúl Romero, Caroline Yezer, and Martin Daughtry for feedback on prior versions of this essay, and to Fulbright IIE and the Wenner-Gren Foundation for funding my initial fieldwork in the Fajardo Province in 2000-2002.

1. The names of all performing groups and individuals discussed in this essay are pseudonyms.

2. For brevity, lyric repetitions have been omitted. In performance, the first line of each verse was repeated, and the second and third lines repeated as a unit ( $\mathrm{AABCBC}$ ). All translations from Quechua to English are by the author.

3. The mandate to "recover the voice of the victims" ("recoger la voz de las víctimas") is made explicit in the final report of the CVR, which also identifies a majority of the war's victims as indigenous people living in rural areas. See CVR, Informe final, www.cverdad. org.pe/ifinal/, accessed June 24, 2013.

4. Ayacucho was one of the only Peruvian departments to register negative population growth in the period between 1981-1993, due primarily to forced migration as a result of political violence. The province of Fajardo suffered one of the most precipitous declines, losing 16 percent of its population during that period, a figure that likely underestimates the extent of outmigration at the height of the violence in the mid-1980s. See Programa de las Naciones Unidas para el Desarrollo (PNUD), La Provincia de Víctor Fajardo en Ayacucho, $17-18$.

5. Nora, "Between Memory and History." Though I find Nora's phrase useful for describing the intentional, ritualized nature of acts of remembrance like those discussed here, the relatively self-contained community in which these song contests take place also poses a challenge to Nora's insistence on separating the lieux (sites) from the milieux (real environments) of memory, the latter of which he argues are lost in the transition to urban life and encroaching modernity.

6. Morris, "The Sound of Memory." Morris's work usefully critiques the overemphasis on the visual, or scopocentric, nature of most work on memory, pointing to the difficult but powerful and emotional role of sound in processes of remembrance.

7. Abu-Lughod, "Writing against Culture." 
8. In addition to other essays in this volume, see Milton, "At the Edge of the Peruvian Truth Commission"; Milton, "Images of Truth." Multiple authors have discussed Ayacuchan artesanía (folk art) as a vehicle for protest and memory, including Isbell, "Violence in Peru"; Lemlij and Millones, Las tablas de Sarhua; González, Unveiling the Secrets of War in the Peruvian Andes; and Jimenez's powerful work as an artist, retablo maker, and author, particularly in Chungui (see also Jiménez's chapter here). For a countervailing view of the resistance to memory, see Yezer's work on rumor, "Who Wants to Know?"

9. Important exceptions to this characterization include Abilio Vergara's recent biography of the testimonial songwriter Carlos Falconí, La tierra que duele de Carlos Falconí, and Vergara's earlier studies cowritten with the ethnomusicologist Chalena Vásquez, including a biography of another testimonial songwriter, Ranulfo Fuentes, Ranulfo, El Hombre; and their joint book on Ayacuchan carnival, ¡Chayraq! Carnaval ayacuchano. Billie Jean Isbell also discusses rural forms of testimonial music in Ayacucho during the war in her article "Violence in Peru."

10. Recent contributions to this literature include O'Connell and Castelo-Branco, Music and Conflict ; Johnson and Cloonan, Dark Side of the Tune; and Ritter and Daughtry, Music in the Post-9/11 World.

11. Emphasis in the original, translation by author. Montoya, Montoya, and Montoya, Urqukunapa Yawarnin, 77.

12. Pumpin music, according to oral tradition in the Fajardo province, has its origins in seasonal labor migration to the Pacific Coast beginning in the late nineteenth century. Young men returned from such work bearing guitars and influences from what they call música quebradeña, music from the deep valleys leading south out of the Andes to the coastal plains of Ica. Adapting the instrument to fit local musical aesthetics, Fajardino guitarists switched to metal strings, doubled the number of courses, and began playing in a much higher register to accompany female singers during agricultural work. Contemporary pumpin music - staged in casual contexts during Carnival or in more formal contests - is usually performed by a small ensemble consisting of three or more male guitarists and an equal or greater number of female singers.

13. Information attributed to Roberto throughout this article pertains to informal conversations that took place during the author's principal period of fieldwork from 2000-2002, as well as later communications in person and over the phone in the many years since. Direct quotes are drawn from a long recorded interview that took place in Roberto's home in Ayacucho on February 18, 2002.

14. Ritter, "Siren Songs."

15. For a history and analysis of early twentieth-century indigenista folklore and its continued influence on performance today, see Mendoza, Creating Our Own. President Leguia's efforts in the 1920 s to promote Andean music as a part of nationalist folklore are analyzed in Turino, "The State and Andean Musical Production in Peru." 
16. See Vergara and Vásquez, ¡Chayraq! Carnaval Ayacuchano. A surviving cassette recording of the first Waswantu concurso in 1976, before the changes discussed here had come into effect, also confirms this characterization.

17. The wayno is the most popular and widespread genre of Andean music and dance, found throughout much of Peru and Bolivia, though marked by significant regional variations in instrumentation and style. The history of political commentary in Ayacuchan waynos, dating back to the nineteenth century, has most recently been surveyed by Vergara in La Tierra que duele de Carlos Falconí, 145-169.

18. Given the poor audio quality of this cassette recording, not all verses of the song are intelligible. This transcription corresponds to verses $4-6$ of the recorded song.

19. See, for example, descriptions of Senderista prison performances in Gorriti, The Shining Path.

20. See Portocarrero and Oliart, El Perú desde la escuela.

21. The denial of prior involvement with "communism" or Sendero is, of course, nearly universal in Fajardo today, given the potentially lethal consequences of admitting to any kind of support for Shining Path in Peru's polarized political climate during the war. This was especially true during the 1990s and early 200os, when the Fujimori administration's draconian antiterrorism laws were implemented to lock up thousands of innocent people for supposed Senderista sympathies. In this case, I have encountered little reason to suspect that Roberto's father was a Sendero militant or sympathizer; he was never identified as such in my many conversations and interviews with others in the province, and as I argue here, his song texts in and of themselves position him as part of the broader Peruvian left rather than the narrow, sectarian Maoism of Sendero Luminoso.

22. Throwing talc powder is a common prank during Carnival.

23. The prisoners are described as "mana ima quchanmanta, mana ima faltanmanta," "blameless and sinless," the very phrase Roberto would use in "Fosas Clandestinas" twenty years later.

24. Information on the songwriter who fled the province is from an interview with the author, February 13, 2001.

25. See, for instance, Conquergood, "Health Theater in a Hmong Refugee Camp," as well as Adelaida Reyes's recent work on music among Ugandan refugees, "Asymmetrical Relations," and her earlier study on music among Vietnamese refugees, Songs of the Caged.

26. Jelin, State Repression and the Labors of Memory, 5.

27. See Turino, Moving Away from Silence.

28. Land invasions were one of the primary methods used by migrants to the city of Lima in the latter twentieth century to obtain property and build new neighborhoods. Targeting parcels of unused-but often privately owned-land on the outskirts of the 
city, organized groups of settlers typically moved in under cover of darkness, and marked out lots, streets, and erected rudimentary shelters overnight. Despite legal challenges and threats and acts of violence by prior owners, many invasions endured to become thriving communities.

29. The phrase yawar waqay, to "weep blood," appears frequently in testimonial songs. Though used colloquially as an emotional intensifier, such as "to sob" or "weep uncontrollably," the reference to "blood" in songs about the political violence also took on a more literal character during the war.

30. Jelin, State Repression and the Labors of Memory, 43-45.

31. A prudent move, as it turned out. The main organizer of the Lima contest in 1984 and 1985 was detained and questioned by the police about his role in the concurso, and he credits his eventual release in part to the printed contest rule forbidding "protest songs." Interview with author, April 8, 2000.

32. See, for example, the brief chapter on pumpin music in Vergara and Vásquez, ¡Chayraq! Carnaval ayacuchano, 369-379.

33. For a detailed account of violence in the Fajardo province throughout the internal war, see CVR, Informe Final, vol. 4, chap. 1.1, www.cverdad.org.pe, accessed June 24, 2013.

34. Listen, for example, to the recording of Fortunato Galindo's "Queja Andina" (Andean Complaint) by the Ayacuchan wayno singer Edwin Montoya, the lead track to his 1966 debut LP Queja Andina.

35. For a useful overview of testimonio as a literary genre and the debates it has generated, including the tensions between individual narratives and collective experiences, as well as the notion of "speaking truth to power," see Gugelberger, The Real Thing.

36. Even a set of songs I recorded in 2001 in Cayara, for example, performed by a group of survivors of the 1988 massacre that took place in that town, contained numerous references to that event but offered no actual narrative of the acts that occurred on that day.

37. The cultural and collective aspects of traumatic experience and recovery in rural Ayacucho are analyzed in compelling fashion by Theidon in Entre prójimos.

38. Such processes of reconciliation are discussed extensively in Theidon, Entre prójimos.

39. Keith Basso quoted in Feld, "Wept Thoughts: The Voicing of Kaluli Memories," 102-103.

40. Quotes taken from the pamphlet " 8 Concurso de Pum-Pin de Washuanto, 1995: Bases Generales," published by the Concejo Distrital de Colca. Document in possession of the author.

41. Flam, Singing for Survival, 5 .

42. Wilson, The Politics of Truth and Reconciliation in South Africa. 



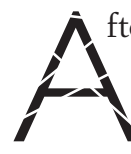
fter an era of massive atrocity, much of it against unarmed people in the name of national salvation or social revolution, hard questions arise. First, even if one sets aside the problem of divided memory about the recent past, is truth-telling possible after a reign of violence so extreme it defies human imagination? Or is truth an illusion? Is it a conceit that merely restores a semblance of normalcy?

Second, if truth-telling is indeed possible, what can art-understood in the broad sense that includes literature as well as performing and visual artscontribute to its making? How do we understand truth when considering the full range of expressive culture? What is the artist's truth?

Such questions have taken on urgency after Latin America's age of "dirty wars" in the late twentieth century. Whether one refers to dictatorial regimes of the 1970s and 1980s in Southern Cone countries such as Argentina and Chile, where rulers used a myth of war to gain freedom of action against citizens redefined into the enemy, or whether one refers to war regimes that indeed pitted state forces against armed insurgents, as in Peru and Central America in the 1980 on and early 1990s, states organized "dirty" war. The dirty war was the zone of atrocity-torture, mystery disappearances, body hacking, massacres - where normal legal rules or cultural taboos did not apply, not even the rules of war. It was also the zone where states could contest the truth of the deed by denying knowledge or inventing cover stories. Dirty war granted the right to violate anybody who stood in the way, or who might serve as a frightening instructive example for others, or who might serve as an instrument of complicity or 
intelligence. In the dirty war zone, the shock of the event that defies the imagination - the disappearance in Argentina that vanishes the person's identity and reality, the massacre in El Salvador that targets babies as well as others for graphic cruelty while turning the pueblo into a ghost town-could have positive value for the regime's goals. For the state and its paramilitary allies - and in the Peruvian case, for the Shining Path insurgents as well-the dirty war's acts of cruel intimidation, even if paradoxically denied in some instances, could educate people that yes, indeed, whatever the brutality required to impose it, a new reality of political rule and social order was arriving.

The toll of such dirty wars in Latin America was huge. The direct victims narrowly defined-the individuals murdered or disappeared or torturednumbered in the hundreds of thousands. In just five countries-Argentina, Chile, El Salvador, Guatemala, and Peru-truth commission estimates of such victims have added up to a baseline of some 340,000 persons, and perhaps as high as 430,000 persons. (Note that this five-country baseline excludes other notable cases for which a quantified baseline is more elusive, for example the torture regimes of Brazil and Uruguay and the undeclared dirty war of Mexico in the 1970s, the Somoza regime's repression to stop the Sandinista insurrection followed by "contra" war to bleed the revolution in Nicaragua in the 1970s and 1980 os, and the intensified cycle of armed conflict and state terror that took hold in Colombia from the 1980s.) Even greater orders of magnitude apply to those who suffered other forms of shocking violence, such as the mass raids and roundups that temporarily converted urban shantytowns in Chile into collective prisons of cruel and degrading treatment, the scorched-earth campaigns in $\mathrm{El}$ Salvador and Guatemala that drove rural villagers into exile and displacement, and the cruel retaliation-and-assassination raids against rural Peruvian communities that also generated massive flight. Put differently, the surviving families and communities directly affected by repressive violence amounted to millions of people. In some regions with large numbers of indigenous peoples in Guatemala and Peru, well-regarded truth commissions considered the scale and racial dynamics of the violence genocidal. ${ }^{2}$

By the 1990 a and early 2000s, as dirty war regimes gave way-to fragile peace settlements in Central America, constrained democratic transitions in 
the Southern Cone countries, the defeat of Shining Path and an eventual democratic transition in Peru - the post-atrocity predicament came into focus. Public policy issues defined one important dimension of the predicament. How should a society of profoundly divided political memory about the earlier regime document the truth of what happened? What did such truth-telling mean for the legitimacy of the post-atrocity regime? What did it mean for victims and their communities, or for justice? Would an official truth commission exercise build a foundation for additional truth-telling and justice or provide a formula for closure and neglect? ${ }^{3}$

Another profound dimension, entangled with the public policy issues but not reducible to them, was cultural. Here the questions raised at the outset of this essay and throughout this book proved crucial. Given the extremes of what happened, was truth-telling really possible? If fact-telling narrative alone was insufficient to grasp what had happened, how could the arts and expressive culture figure into the process?

At stake, both culturally and politically: the making of a new common sense and moral imperative in the wake of a devastating experience.

Not surprisingly, the Holocaust gave rise to some of the most profound and difficult reflections on truth and art. The problem is not the province of any one world region or historical experience. From a world history perspective, we may consider the problem of truth-telling and art the post-Auschwitz predicament, understood as an issue that unfortunately recurs in distinct contexts. As Saul Friedlander put it in a sensitive essay, the historian of the Shoah must resist "the temptation of closure" because the narrative must work with the "excess" factor. The analytical intellectual work may build a certain protective numbing and allow for valid and rigorous insight, but to work in this dimension alone may also amount to avoidance. There is something extra that defies words that belongs to deeper memory and meaning of the event-and that must break through to disrupt distance. A narrative that seals the story is misleading. ${ }^{4}$

This book matters substantively and theoretically. It matters because it raises profound questions about truth and art for the case of Peru after the Shining Path war of the 1980 s and 1990s. It also matters because in analyzing Peru it enriches and troubles more general reflections on art and society. 
Consider the most famous dictum on art and society in the wake of twentieth-century atrocity: "To write poetry after Auschwitz is barbaric." For more than a half century, Theodor Adorno's aphorism has drawn attention. It is irresistible because it seems to distill the contemporary predicament- the burden of living with the legacy of regimes of organized violence so massive and extreme, yet so closely associated with modernity, that they overwhelm our capacity to describe or comprehend, let alone accept and move on. The sheer outsized quality of the offense makes it incommensurable with what we think we can know in normal life. It creates a time beyond normal time. It imperils faith in the future and in progress, that is, modernity. What happened is a "crime against humanity" not simply for reasons of legal taxonomy but, more fundamentally, because it assaults the idea of the human. As Hannah Arendt put it, acts of radical evil seem to "transcend the realm of human affairs and the potentialities of human power, both of which they radically destroy wherever they make their appearance." 5

Adorno's remark sums up the shattering sensibility. After the times of radical evil that create experiences beyond the limit, human expression and artistic endeavor fall short. Representation is a mirage. To pretend that culture can redeem its own failure is an absurdity. To consider art possible is to fall into a consoling but barbaric illusion.

The power of Adorno's insight, however, creates the risk of reifying his point into a clichéd universal truth rather than grounding it in a particular historical context. When Adorno wrote his words in 1949, the point was to shatter complacency - the unthinking belief, almost as an act of sacred faith, in return to a restored German culture in the Federal Republic. The broader underpinning was the sense that Auschwitz was the ultimate metaphor and climax of modern history. A history of catastrophe, evident since World War I, had brought humankind ever closer to the total society of the "open-air prison" accompanied by "reification of the mind." Even in the West, culture was untruth and the cultural critic paradoxically imprisoned by the terms of the critic's creation. The original German sentence that contained the provocation had aimed at this more complex point: "Cultural criticism finds itself faced by the final step in the dialectics of culture and barbarism: to write a poem after Auschwitz is barbaric, and this also erodes the realization that states why it has become impossible 
to write poetry today." Adorno labored for decades to create a philosophy of "negative dialectics" that stripped away the association of dialectics with an affirmative outcome. ${ }^{6}$

When Adorno declared the barbarism of poetry, he had especially in mind lyric poetry, or in broader terms the project of redemptive culture. His stance was more ambivalent and fluctuating - more paradoxical — than a flat aphorism. "That culture so far has failed," he had warned in 1944, "is no justification for furthering its failure, by strewing the store of good flour on the spilt beer." He built a life continually entangled with writers and artists, including some who wrestled seriously with what art could be after the disaster, and was himself drawn to the study of music and aesthetics. In his 1966 conclusion to Negative Dialectics, Adorno conceded that he had overstated the point in one sense-while understating it in another. Torture and suffering produce a right to scream and express, and "hence it may have been wrong to say that after Auschwitz you could no longer write poems." What remained valid was "whether after Auschwitz you can go on living-especially whether one who escaped by accident, one who by rights should have been killed, may go on living. His mere survival calls for the coldness, the basic principle of bourgeois subjectivity, without which there could have been no Auschwitz." Yet humanity also contended with a "new categorical imperative" whereby people had "to arrange their thoughts and actions so that Auschwitz will not repeat itself."

In other words, Adorno wrestled with his own insight. He sought to salvage art in some way. He embraced the art of unsparing tension between reality and imagination - "the cleft between what human beings are meant to be and what the order of the world has made of them." Art had truth value insofar as it destroyed the lie. "The concept of a cultural resurrection after Auschwitz is illusory and absurd," he wrote in 1962. "But because the world has outlived its own downfall, it nevertheless needs art to write its unconscious history. The authentic artists . . . are those in whose work the uttermost horror still quivers." 8

One contribution of this book is that in demonstrating the urgency and insight of the arts of truth-telling, it pushes us to contextualize rather than treat as universal the aphorism that hovers over narrative in the aftermath of atrocity. This point, a premise in the eloquent introduction by Cynthia Milton, gains force as recurring implication in the case studies that follow. In the long run, 
Adorno's point was both to condemn art as an impossibility and to affirm it as the only possibility. Art risks falling into the lie of restoration and redemption. Yet it also proves indispensable to break the silence and indifference at the heart of the lie. This book pushes us to see and accept the enduring value of this paradox.

Consider the implications of this book for a second approach to art and society, focused on the artist. Latin Americans, wrote Jean Franco in The Modern Culture of Latin America, a masterful history of literary and artistic expression since the late 1800 , have "generally viewed art as an expression of the artist's whole self: a self which is living in a society and which therefore has a collective as well as individual concern." The idea of art for its own sake did not translate so readily into a cultural assumption about "the moral neutrality or the purity of art." The legitimacy of art as "a self-propagating tradition in which new movements may arise as a solution to technical problems" was stronger in Europe. ${ }^{9}$

Franco's point was subtle, more relative than absolute. It was about artistic technique, authenticity, and imperative in social and political context. The purpose was not to establish a simplified contrast between Europe and Latin America as aesthetic realms rigidly governed by individualistic versus socially minded artistic sensibilities, respectively. On the contrary, her analysis drew out the significance of European life experiences and cross-influences for Latin American writers and artists, and the irony that some adopted the stance of the superior calling or sought a kind of exile or mental refuge in art. Whatever the stance of the artist, however, the social question exerted a foundational influence on the legitimacy and subject of the work. Cultural expectation pressed the lettered person into the role of society's mentor. In this context, refusal to respond was itself a response. And the social question was profoundly explosive and unresolvedstructures of injustice and backwardness provoked controversy, defining the national community proved conflictive and problematic, projects of nationalism and revolution caught the imagination. Hence Latin America experienced a history of artistic "fresh starts," ruptures rather than a working out of immanent artistic tradition. Artists assimilated, adapted, or invented techniques to respond to the "new social situation" that defined them. ${ }^{10}$

In this perspective, long before the disaster of the Shining Path war, Latin 
American artists found themselves pushed to engage the sometimes synergistic tension between art as a creative invention or refuge in its own right and art as an unsettling intervention inspired by a societal condition. Some navigated the tension by creating breathing room-explicit distinction between the civic statement offered in a role as society's guide or celebrity and the creative work that requires space for inventiveness, ambiguity, and play. The creative space was not reducible to a political pronouncement or gatekeeping mentality, even if the social question exerted a direct or indirect influence. Gabriel García Márquez's Cien años de soledad (One Hundred Years of Solitude; 1967) said something profound about the great 1928 banana massacre in Ciénaga, the historical event that is the climax of the novel. But the world of Macondo did not reduce to the politics of banana labor. As he gained international stature, García Márquez would explain that as a Latin American whose novels had created a reputation, "the only choice I have is to be an emergency politician." To do otherwise was unacceptable, "considering all that is going on in Latin America." But this activity was not the same as creating literature. Yet he would also, on accepting the 1982 Nobel Prize and describing the political horror afflicting South and Central America, echo Jean Franco's point that the social question inspired literary technique. "Poets and beggars, musicians and prophets, warriors and scoundrels, all creatures of that unbridled reality, we have had to ask little of imagination, for our crucial problem has been a lack of conventional means to render our lives believable."11

Put differently, Latin America situations sometimes turned Adorno upside down: barbarism inspired art.

Yet Franco's interpretation also emerged in a particular historical context: the long 1960s. Her insightful study was published in a revised edition in 1970, after a first edition in 1967. It expressed a certain convergence: the Latin America that experienced the upheaval of a politics of revolutionary projects with the Latin America that won a "boom" reputation in literature and the arts. This was the Latin America where political debate was often framed as structural reform versus outright revolution and where the artist's relationship to society had regained a strong political salience. The decade opened with the Cuban Revolution of Fidel Castro in 1959 and closed with the election of Salvador Allende in Chile in 1970. Meanwhile, García Márquez won international acclaim 
for Cien años de soledad, published in 1967, and Latin American writers drew attention and translations as a world literary phenomenon. In 1967, the Guatemalan novelist Miguel Angel Asturias, whose novels of the dictator-president and Maya peoples of maize merged political and artistic sensibilities, won the Nobel Prize in Literature. In 1971, Chilean poet and Communist Pablo Neruda, who backed Allende and therefore withdrew his own presidential candidacy, won the Nobel Prize. ${ }^{12}$

The moment passed. More precisely, it gave way to nightmares. The long 1960 s gave rise not only to the politics of reform versus revolution but also its antithesis: policide. A wave of violent right-wing dictatorships took hold in South America in the 1970s and determined to create a new style of military rule: not a caretaking role but a project to root out once and for all the old ways of thinking, mobilizing, and doing politics. At their most grandiose moments, the new regimes styled themselves as the frontline leaders of the West and the Cold War. Their methods were both repressive and educational— not only torture, killings, and disappearances but also discourses of modernity, law, and progress. The new military juntas of Argentina, Brazil, Chile, and Uruguay aimed not only to rid society of Communists, and dissenters of the Left or Center who served as their unwitting allies, but also to create citizenries educated to accept a new technocratic order. Peru followed a distinct path to nightmare. A reform-minded military junta came into power in 1968 and gave way to a conservative junta in 1975, and then came, under pressure of social movements, a democratic transition and elected civilian president in 1980. But most important, the 1970s witnessed the ideological formation of Shining Path, at first an unimpressive leftist splinter party, and culminated with its launch of a revolutionary war that proved shockingly brutal, resilient, and expansive during the 1980s. Meanwhile, civil wars produced an inferno of violence in Central America, especially in Guatemala and El Salvador, where military regimes engaged in scorched-earth campaigns. ${ }^{13}$

The new era destroyed the earlier convergence. In a study aptly entitled The Decline and Fall of the Lettered City, published in 2002, Jean Franco considered the long-term cultural consequences of the dirty-war dictatorships and civil wars that swept over Cold War Latin America in the 1970s and 1980s. As violent regimes gave way to democratic transitions in the 1990s, what remained was a deep transformation consolidated on their watch: the rise of a more neo-liberal 
scheme of economy and culture that altered the relationship of the individual to society. The market was the fundamental metaphor and relationship, and culture was now "overwhelmingly the province of entertainment and of comfort activities that in turn generate 'lite' criticism that never challenges the doxa." The modernist and statist conceits that once undergirded utopias as well as the lettered artist or intellectual had collapsed. Commercialization reigned, and serious cultural work retreated to the margin. Despite the bleakness, Franco refused to end pessimistically, "for something is still alive among the rubble if only an effort of will." ${ }^{14}$

The collapse was not altogether bad, since what destroys may also set free. Less suffocated by conceits of state and modernity and less tethered by political party or utopia, new voices of expression, dialogue, and insistence may arise from the margin and inspire new cycles of testimonio or bearing witness by indigenous peoples, women, human rights activists, gays, environmentalists, and outcasts of the underclass, such as prostitutes and homeless. ${ }^{15}$

A second contribution of this book is that it enables us to contextualize the crisis of high culture and the artist-society relationship differently, within a more holistic and culturally inclusive framework. The crisis emerged in distinct contexts and historical moments in Europe and Latin America. But Adorno and Franco also had something in common. Both worked fundamentally with high culture, although Franco was sensitive to the "seduction of margins," and both provided evidence of its crisis. Their portraits of crisis, although pioneering and insightful, were incomplete. ${ }^{16}$

The arts of truth-telling analyzed in this book enable us to see the "something still alive among the rubble." When we expand our range of vision to include popular culture as well as high culture and the brokers in between, we can discern what has not been lost. A space of insistence on art that engages the social question has continued to emerge in Latin America. But the space of artistic insistence is populated by different actors, including many of popular origin.

The diverse studies in this book make this point abundantly clear. Víctor Vich and Cynthia Garza invite us to consider how "high art" forms such as the novel and theater, respectively, may aim to collapse social distances and complacency. Storytelling forms that might otherwise be dismissed as "folk art" — the graphic novel created by Luis Rossell, Alfredo Villar, and Jesús Cossio, the pumpin 
Carnival songs researched by Jonathan Ritter-acquire salience in this book as urgent art, a witnessing whose fusion of truth, poignancy, and imagination open up the viewer-listener to the sorrows of a devastating experience. Yet the collapse of a hierarchical aesthetic boundary between "high" and "low" does not suffice to capture the artistic climate and vitality. In the space of social insistence on an art of post-atrocity, new methodologies also emerge, as in Edilberto Jiménez’s ethnographic drawings, whose very premise is collaborative grassroots testimonial. New artistic actors appropriate a preexisting genre and adapt it to new publics, as in the filmmaking of Palito Ortega, who insists in his interview with Ponciano del Pino that his cinema, inspired by life and fear in Ayacucho, is uniquely suitable as a mirror in which highlanders can find themselves and their experiences. New brokers, including NGos, promote grassroots art as valuable and indispensable, as in the community art and commemoration contests analyzed by Cynthia Milton and Ricardo Caro Cárdenas, respectively. And new necessities for cultural authenticity arise among social actors or officials "from above," as in María Eugenia Ulfe's striking depiction of the transformation of the retablo, the "popular" art of small painted open-door triptych boxes, into a giant stage for the ceremonial delivery of the truth and reconciliation report to the people of Ayacucho.

The collapse of strict high-low boundaries and the attendant emergence of new brokers to mediate artist-society relationships differently is not an altogether new phenomenon. One of the features of the political and cultural ferment in Latin America in the long 1960 s was precisely the desire to expand the circle of valid artistic expression. Discovery and promotion of lo popular opened the aesthetic door to new styles and new artists - to "folk" expression and its creators. For truth-telling after the times of atrocity, what may be most revealing is not the crisis of high culture and the lettered city but the shifting balance among artistic actors who bring to their creative work dramatically varied social capital. Just as civil society actors who sometimes seemed marginal took on the burden of pressing the post-atrocity state not to settle for quick closure of human rights work related to truth, justice, and cultural memory, so it is that artists of popular or self-made background may shoulder more of the imperative to create an art that refuses the lie. In both cases, transnational and NGO connection has also 
proved significant. The artists and brokers described in this book help us see and consider this shifting balance, but they did not come from nowhere. ${ }^{17}$

As Milton observes in her essays, after atrocity artistic expression offers different ways of knowing and bearing witness to experience - thereby pulling people into what otherwise might remain unknown or pushed aside. Art multiplies the expressive paths we can take to somehow imagine, apprehend, and convey truths of a reality whose "plus" factor (Friedlander's "excess") is so extreme it seems to defy the real and the believable. The essays in this book provide grounded case studies, important in their own right and in their diversity, of the ways artistic expression in a post-atrocity society can turn into the moral imperative of truth-telling.

Taken together, the essays also do something more. A third contribution of this book is that it demonstrates the deep interplays - a kind of intimate entanglement - of aesthetics, authenticity, and empathy in the making of artistic truth-telling claims for a postcolonial society. In a society such as Peru, where the "coloniality" of social relations outlasted Spanish rule and sparked not only conflict but sensibilities of national fragmentation, the barriers to truth claims were formidable. The social divides and conflicts were not only economic but also ethnoracial, not only national but also regional and linguistic-cultural, not only recent but also historically entrenched. Put differently, a central aesthetic challenge of art as truth-telling has been how to deploy authenticity and evoke empathy across profound social division, thereby creating imaginative "pull" into unfamiliar and difficult zones of experience. Creating such pull has not been a simple task, precisely because to a large degree the Peruvian nation, especially in its legacy of war and atrocity in the 1980s-1990s, remained a society of "still colonized" and "still colonizing" communities.

The book's insight on intimate entanglements of aesthetics, authenticity, and empathy to create artistic ways of knowing and bearing witness to truth emerges cumulatively, as a leitmotif across the case study essays. Consider authenticity. Milton and Ulfe show in distinct ways that even for a blue-ribbon truth commission intended to provide a solemn nonfictional narrative of what had happened, an artistic aesthetic that evoked the "deep Peru" of highland society 
proved fundamental - to prime rural highlanders to give their testimonies to a commission from Lima, to provide an anchor of legitimacy for the delivery of the report in the highlands, and to forge a space for continued truth-telling and social repair claims after release of the report.

Consider empathy. Jiménez and the team of Rossell, Villar, and Cossio show that to convey truths powerful enough to destroy the convenient lie, to undermine the impulse to look away from horror, and to reach across social divides, artists have coupled the ugliness of the story with aesthetics of humanization that invite the reader-viewer to continue onward. The artists came at the issue from opposite angles. Jiménez's ethnographic drawings focus on the experience of rural comuneros (community residents) in Chungui. The depictions and texts are profoundly disturbing, but the shocks of violence come with techniques that invite the reader to identify rather than go numb - the collaborative first person voice that creates a you-are-there sensibility; the scene so poignant, as in forced conscription of children, that it undermines simple political othering of victims; the drama of human anxiety and problem-solving by villagers haunted by the fear that turning themselves in for protection and a new start will backfire, because others will assume they are Senderistas. The coauthors of the graphic novel Rupay focus on Lima-based journalists who were killed by Uchuraccay comuneros in 1983 as alleged Senderistas. They turn the Limeños into simpático subjects of a mystery story within a mystery story. The journalists joke about their own lack of physical fitness as they make the tough trek up the Andes to investigate an early war massacre in Huaychao, only to have their own disastrous fate in nearby Uchuraccay turn into the unsolved puzzle. The alternation of comic-book panels with occasional documentary photograph panels not only drives home the reality of the Limeño victims as (once) living human beings but also subtly reinforces empathy by avoiding the stereotyping of Indians. They are no longer the ignorant or savage comuneros who often inhabit the nation's official narratives.

Consider, finally, aesthetics. Garza's study of the experimental theater of Yuyachkani presents an artistic transformation of the medium to break apart "normal" conventions of performing and viewing, and of daily life itself, that might otherwise enable us to draw distance from, rather than take common ownership in, the experience of violent power. But the main point is not aesthetic experi- 
ment for its own sake, that is, for developing art in its immanent sense as technique and imagination. The point is to anchor violence within a longer history that renders it deeply authentic - the problem is entrenched in who we are as a historical people, it is not a passing issue of who we recently became. The point is also to achieve a dissolving boundary between "your body" and "my body" that can liberate an unknown capacity for empathic experience. In a different way, Ortega and del Pino's interview-essay also points to multidirectional entanglements. What fires the aesthetic imagination is moral imperative-a social duty to create an artistic voice that can capture the true experiences of authentic Peruvians otherwise invisible, neglected, or stereotyped by the Lima-centric nation. What defines aesthetic success is that ordinary serranos (highlanders) can finally see themselves on screen in a manner that breeds recognition and identification. As Ortega puts it, the testimonial passion of his work derives from "a moral obligation to tell stories not created in my head, but by reality. I've lived through it in Ayacucho."

The making of memory is also a making of silence. Memory is not simple recall of past events but an evocation of their meaning as human experience. In many post-atrocity societies, including Peru, the memory question-defining indisputable core facts and meanings of an era of terrifying violence-is conflictive and even explosive. It feeds struggles over sociopolitical legitimacy, social repair demands, legal and criminal accountability, and the future direction of politics and society. In a transitional post-atrocity society, one memory camp may use some alleged facts and meanings as a club to pound the other. Within a given community or memory camp that has suffered repressive violence, moreover, some themes may prove divisive and therefore place at risk the internal coherence needed to seek redress. In short, the sociopolitical "struggle" aspect of memory may yield sensitive taboo topics. ${ }^{18}$

In addition, the personal experience of trauma - the extreme humiliation and pain that undermines the person's integrity and produces shame-may also yield difficulties of telling. Trauma can elude integration into a life narrative, turning the person into a divided soul, caught between the shattered self of deep memory of another time and the rebuilt self who navigates banal everyday time. Even if the person who rebuilds life finds a way to create a more integrated life narrative 
and indeed feels compelled to bear witness, some aspects of experience may remain so sensitive and challenging that they also turn into silence. ${ }^{19}$

The arts of truth-telling, even if they open up alternative ways of knowing and bearing witness, do not escape the sociopolitical and personal dynamics that breed silence-the sense of danger that surrounds the taboo topic. In a society of memory struggles to shape the present and future, remorse about a person or a community's past choices or actions is among the most difficult areas to engage. In the Peruvian case, the sensitive subject par excellence has been complicity in the making of the terror-whether in alignment with Sendero Luminoso and its beachhead of initial support in rural communities or with the state and its lethal dirty war campaign.

A fourth contribution of this book is that it enables us to "see" how silence, especially public speech taboos about known but unacknowledged secrets, inflected the making of art. For artistic truth-telling, like truth-telling more generally, the dialectics of memory and silence were powerful. Remembrance necessarily implied selectivity: a focus on what was most important to remember about the experience of violent repression and why. The opposite side of the same coin was silencing of some aspects of the past that might turn into a perverse instrument to deny key facts or to deflect responsibility for the victim's suffering.

As with the other insights of this book, the mutual constitution of memory and silence is a point that gains force because it recurs, with variations, across several essays. Ritter's nuanced study of pumpin song demonstrates that only with the reemergence of pumpin after its initial repression in the Fajardo countryside in the early 1980 os did it turn toward a "testimonial" aesthetic, defined in contrast to an earlier protest aesthetic that had been partly instrumentalized by Shining Path and partly embraced by comuneros. In tracing the Sacsamarca community's commemorative reenactments of military resistance to Shining Path in May 1983, Caro Cárdenas analyzes how social actors and sensitive themes generated a shifting dialectic of remembrance and parody on the one hand, silence and discretion on the other.

These chapters contribute to an exciting cluster of new microstudies, at once historical and ethnographic, of communities in the Ayacucho region. These microstudies draw out histories of community fissure and longing that laid a foundation for complex local engagements of Shining Path during the 1980s- 
including transitory and partial bases of support, ambiguous stances of coerced complicity and "resistant adaptation," transitions toward organized resistanceand community fratricide. The latter created a legacy of touchy community secrets after the war. As Olga M. González brilliantly demonstrated in her study of Sarhua and its famous art of tablas (painted boards), one may analyze art itself as a memory narrative whose silences - in this case, about circumstances related to the disappearance of one comunero, the assassination of another, and initial community responses to Sendero-opens the door to discovery of the deep inner history of a community and its necessary secrets. ${ }^{20}$

In other cases, the point of art is precisely to expose the silence that looks away from other kinds of complicity or that becomes a different way of bearing witness to violent suffering. On both counts, Vich's study of Alonso Cueto's novel La hora azul is revealing. Adrián Ormache, the lawyer-protagonist, discovers a family secret that brings out into the open the reality of rape as military prerogative and weapon during the state's dirty war campaign in the highlands. At the same time, his attraction to the victim-survivor Miriam and her son (and his possible half-brother) Miguel brings him into contact with a different kind of silence-that of the victim whose silence speaks loudly about an experience beyond words.

This book draws out the dialectics of memory and silence in artistic truthtelling. At the same time, it does not claim to exhaust the full range of potential themes - and in that sense produces its own silences. As Milton notes, this book does not engage the memories of the military actors or Shining Path militants. These actors matter not only because they waged war but also because they generated sympathizers, not simply opponents, and suffered violence that could turn them into victims or even hero-victims in some eyes. Such sympathies and ambiguities fed the divisiveness of the memory question and complicated social responses to art. As Katherine Hite and others have shown, El Ojo que Llora (The Eye That Cries), one of the most moving memorials to victims of the war violence created after the truth commission's 2003 report, had great empathic power-but also, precisely for this reason, great capacity to spark conflict. Sited in a park in Lima's centrally located Jesús María municipality, El Ojo que Llora is a sculpture centered on Pachamama, the Andean Mother Earth, in the form of a giant sorrowful rock, of a type found on the Andean coast and dating to 
pre-Inca times, within which appears an "eye," a smaller rock that continually releases water. From the eye of the Pachamama, tears drip into a pool. To reach the rock, one must undertake a journey through a labyrinth bounded by bands of 32,00o smaller rocks worn smooth by Andean sun and sea, each representing a victim, and among them some 27,00o rocks with painted inscriptions of the names and ages of individual victims and their year of death or disappearance.

Yet who could legitimately be included among the victims? Should the names include Senderista prisoners subjected to slaughter in military raids? Should they include soldiers, some of whom had been drafted? Such questions sparked anger and led to physical attacks. The most notorious took place in September 2007 when assailants beat up a guard and proceeded to smash stones and throw orange paint on the Pachamama. ${ }^{21}$

An additional silence is regional. Did artistic truth-telling advance most intensely in metropolitan Lima and the Ayacucho region-precisely the two regions featured in the book? Lima was the cultural, media, and political center of the official nation that sponsored a truth-telling commission. Ayacucho was the highland region that gave birth to Shining Path as a coherent political group and that also drew attention as the region that first experienced genocidal slaughter. Yet the war expanded over time to other regions - not only to other highland regions such as central sierra provinces north of Ayacucho and east of Lima but also to jungle regions and Amazonian peoples such as the Asháninka, who also experienced devastating slaughter. To what extent was artistic truth-telling less pronounced, or less able to draw on state or NGO actors for support, in these regions of post-Shining Path Peru? ${ }^{22}$

One of the pioneering contributions of this book, therefore, is not only that it enables us to see the ways artistic memory-making is bound up with makings of silence. Its insights also enable us to perceive and ask new questions - to begin to probe other silences.

What, then, is the artist's truth? At one level, of course, the question is profoundly misleading. As this book shows, there are many artists and many artistic truths about the experience and meaning of violent atrocity - and its continuing presence, as something still foundational in the making of post-atrocity society. 
Yet at a different level, that of aspiration and dilemma, the question defies such easy dismissal. In Latin America, whose artists and intellectuals have long wrestled with their relationship to the social question, the answer of "many artists and many truths" does not fully convince. Taken too far, it can sound like evasion, an unacceptable slide toward self-complacency. In the early twenty-first century, the unacceptability factor is all the more compelling because the era of dirty war created, as legacy and memory struggle, a Latin American version of the post-Auschwitz predicament. Indeed, one legacy of the era was an eclectic array of artistic actors from many social backgrounds, many of whom are themselves survivor-witnesses.

And herein lies the artist's truth. Art happens at the intersection of experience and imagination. In post-atrocity Peru and other post-atrocity societies of Latin America, Adorno's dictum in its more nuanced and paradoxical sense has come roaring back to life. It is the dilemma and aspiration that the socially engaged artist cannot avoid. How and why do we imagine what happened? Once we find a way to imagine what happened, how and why do we turn it into a moral imperative and life force?

The artist's truth is the dilemma itself. The impossibility of art as a medium to grasp fully an experience beyond limits does not cancel out its imperative as the only possibility. The danger that art will slide toward a redemptive project of closure does not cancel out the imperative to imagine the harrowing gap between what humans become and what they are meant to be. In entering that gap, art invites us to see and somehow take in as truthful experience that which is otherwise too difficult to stare at. It shatters, yet in so doing can prompt the difficult question that also affirms life: what will we do with the imperative created by this experience? The heart quivers, and yet it beats.

\section{Notes}

1. The international dimension of dirty war regimes was fundamental both within and beyond Latin America and has recently drawn renewed attention from historians.

For dirty war and the making of a new international regime of human rights, an excellent introduction is Wright, State Terrorism in Latin America; cf. Stern, Reckoning with Pinochet, 357-386; and for pioneering contributions from political science and anthropology, respectively, Keck and Sikkink, Activists beyond Borders, esp. 1-38, 79-120, and 
Tate, Counting the Dead. For reconsideration of Cold War connections, superb studies are Joseph and Spenser, In from the Cold, and Rabe, The Killing Zone; for work setting the Cold War within stretched time lines and a globalized history of Third World revolutions, respectively, Grandin and Joseph, A Century of Revolution, and Westad, The Global Cold War; and for locally grounded political understandings of transnational solidarity, Stites Mor, Human Rights and Transnational Solidarity in Cold War Latin America.

For Shining Path and its cult of violence, the scholarly pioneer is the late Carlos Iván Degregori, How Difficult It Is to Be God; cf. Gorriti, Sendero; Portocarrero, Razones de sangre.

For dirty war regimes as "policide" - a root-and-branch killing off of earlier ways of understanding and doing politics - see also n. 13 here. For a beautifully researched and vivid example that policide projects did not fully succeed, even in scorched-earth contexts that drove peasants into refugee status beyond national borders, see Todd, Beyond Displacement.

2. The baseline numbers of the dead, disappeared, and tortured in the five countries amount to a verified partial accounting through national or international truth commission reports. The truth report numbers that yield some 340,000 victims as a reasonable low-end number are as follows: Argentina-8,96o disappeared; Chile-40,277 disappeared or killed or tortured (the dead and disappeared amounted to 3,197 in 1990 s reports, and 30 additional cases in a 2011 report; prisoners politically imprisoned amounted to 27,255 in a 2004 report, and an additional 9,795 cases in a 2011 report); El Salvador-over 22,00o dead or disappeared; Guatemala-about 200,000 dead or disappeared; Peru-69,280 estimated dead or disappeared. These figures total 340,517 victims. Yet as the reports for Argentina and El Salvador acknowledged, truth commissions wrestled with evidence that many more cases had occurred than those that had been individually denounced and sufficiently documented to certify officially. As the Argentine report noted, "we also know that many disappearances have not been reported, because of lack of relatives of the victims, because of preferences to remain quiet, or because of living in places far from urban centers, as the Commission learned in visits to interior regions where many relatives of the disappeared indicated to us that they did not know where to go in past years." (See the opening of chap. 2 of the report, as cited in the online edition below.) The Chilean report on torture made a similar point about the difficulty of coming forward for those who had suffered extreme humiliation. For two countries - Guatemala and Peru - the commissions included in their figures an estimate methodology to supplement direct individualized case work. If one holds to a conservative methodology for the other three countries, reasonable adjusted estimates are as follows: for Argentina, 20,00o disappeared is the midpoint in the commonly accepted range of 10,000-30,0oo disappeared; for Chile, 64, ooo dead, disappeared, or 
tortured takes account of 60,000 as a conservative baseline (midway between 50,000 and 70,000) for torture and 4,000 as a baseline (midway between 3,500 and 4,500) for deaths and disappearances; for El Salvador, the widely accepted estimate is 75,00o dead. These adjustments would raise the five-country total to $428,28 \mathrm{o}$.

Under the circumstances, the range of 340,000 to 430,000 victims is a reasonable order of magnitude for the dead, disappeared, and tortured in the five countries. It is probably understated, moreover, in view of lack of systematic accounting for tortured persons who survived, except in the case of Chile. For the five countries as a whole, the time frame under consideration may be construed as a two-decade period from the early 1970 s to early 1990s, with variation in the specific dirty war periods of specific countries. It should be noted that other countries that engaged in dirty war followed time lines that spilled somewhat outside this range. In Brazil, for example, the military toppled a democracy in 1964 and its repression hardened notably in 1968, while in Paraguay, the regime of Alfredo Stroessner dated to 1954 but joined the 1970 transnational scheme of South American dirty war known as Operation Condor. For Latin America as a whole, one may think of the dirty-war era under consideration here as the "long" 1970s-1980s, while recognizing that chronologies of individual countries varied.

For the official reports and figures for Argentina, Chile, El Salvador, Guatemala, and Peru, respectively, see the following websites, www.desaparecidos.orgn/arg/conadep /nuncamas/indice.html, accessed June 10, 2012; www.indh.cl/informacion-comision -valech, accessed June 10, 2012; www.usip.org/files/ElSalvador-Report.pdf, accessed June 10, 2012; shr.aaas.org/guatemala/ceh/mds/spanish/toc.html, accessed June 10, 2012; and www.cverdad.org.pe, accessed June 10, 2012. For additional background on the Chilean case, where figures developed through a cumulative process involving four different official reports - a foundational truth commission report in 1991 on deaths and disappearances, a follow-up report on deaths and disappearances in 1996, a new truth commission on political imprisonment and torture in 2004, and a follow-up to consider additional cases of torture, deaths, and disappearances in 2011 - and where the torture report also prompted criticism by some shantytown residents and human rights activists about the exclusion from consideration of massive and brutal violence during shantytown raids, see also Stern, Reckoning with Pinochet, 65-98, 286-297, 325-329, 390-392n. 3; 465n. 72 .

3. For distinct approaches by two influential activist intellectuals, see Zalaquett, "Balancing Ethical Imperatives and Political Constraints," and Juan E. Méndez, "Accountability for Past Abuses"; for tension between truth-telling as a formula for closure and as a wedge for expanding work, Stern, Reckoning with Pinochet; for truth commissions in comparative context, Hayner, Unspeakable Truths. For pioneering research on shifting responsiveness by judicial actors, including both domestic and transnational dynamics, 
see Collins, Post-transitional Justice; Huneeus, "Judging from a Guilty Conscience"; Lutz and Sikkink, "The Justice Cascade"; Sikkink, The Justice Cascade. For an insightful and sobering cautionary tale on international justice, Cruvellier, Court of Remorse.

4. Friedlander, "Trauma, Transference and 'Working Through' in Writing the History of the Shoah," 52.

5. For quotes, see Adorno, "Cultural Criticism and Society," in Prisms, 34; Arendt, The Human Condition, 216. For thoughtful discussion by literary scholars of the Adorno thesis, see Bernard-Donals and Glejzer, Between Witness and Testimony, and for an interesting inversion, Bartov, Mirrors of Destruction, 211-212. For Adorno's thought in context and its significance and controversial aspects in his own era, see sources in n. 6 here.

6. For quotes, see Adorno, Prisms, 34, and for the German sentence that frames the Auschwitz-poetry problem in a manner more complex than the short stand-alone sentence in English translation, Adorno, Gesellschaftstheorie und Kulturkritik, 65. That the translators were aware that the "remarkable syntactic flexibility" of German can create an intrasentence thought process - a dynamic tension of thinking within the sentencein contrast with English syntactical convention is clear from the prefatory essay by one the translators, Samuel M. Weber, "Translating the Untranslatable," 13. For the masterwork on dialectics, see Adorno, Negative Dialectics. I thank Geneviève Dorais for research assistance on Adorno and his intellectual circles and acknowledge my intellectual debt to three key works that set Adorno's life and thought in context: Claussen, Theodor Adorno, esp. chap. 8 (note date, lecture style, and context of Adorno's essay "Cultural Criticism and Society," 261); Müller-Doohm, Adorno, esp. pt. 4; Jäger, Adorno; and for superb analysis of Adorno's dictum, attentive to language and to Adorno's dialectics and overall thought, Hofmann, "Poetry after Auschwitz." I follow Jäger's translation, Adorno, 186, in my rendering of the complex German version of Adorno's dictum. For useful scholarly readers on Adorno's thought and work, see also Huhn, The Cambridge Companion to Adorno; Gibson and Rubin, Adorno; see also Adorno, Can One Live after Auschwitz?

7. For quotes, see Adorno, Minima Moralia, 44; Adorno, Negative Dialectics, 362-363, 365. See also n. 8 here.

8. For quotes and Adorno's clarifications of his stances on art and lyric poetry, I am especially indebted to Müller-Doohm's trenchant analysis in Adorno, esp. 356 ("cleft"), 403-404 ("resurrection"), 405, 470-474; also helpful is Nikolopoulou, "As If."

9. Franco, The Modern Culture of Latin America, 11.

10. See Franco, The Modern Culture of Latin America, 11-12, for quotes.

11. For "emergency politician" reflection, see Dreifus, "Playboy Interview"; and for speech, given on December 8, 1982, "Gabriel García Márquez-Nobel Prize Lecture," at www.nobelprize.org, accessed April 6, 2012. For a fascinating cautionary tale on the dangers of reducing life to the politics of banana labor or its famed literary expression by García Márquez, see LeGrand, "Living in Macondo." 
12. If read as a document of the era, Franco, Modern Culture, is a fine example of this convergence; for the "reform versus revolution" sensibility, a good starting point is Petras and Zeitlin, Latin America; for the Nobel Prize in Literature, see list at www .nobelprize.org, accessed April 6, 2012.

13. For overview of events, see Rabe, The Killing Zone, and the other sources cited in $\mathrm{n}$. 1 here; for the concept of policide specifically, see Stern, Remembering Pinochet's Chile, esp. xxii-xxiii, 31-32, 180-181n. 27, and for nuances in relation to "genocide," Stern, Reckoning with Pinochet, 99-105.

14. See Franco, The Decline and Fall of the Lettered City, 261, 275, for quotes.

15. Franco herself offers a perceptive analysis in The Decline and Fall, 201-219, and for classic formulation of the making of new cultural hybridities in Latin America, see García Canclini, Hybrid Cultures; cf. Monsiváis, Mexican Postcards. The most internationally well-known subaltern testimonial voice from Latin America in the 1980 and 199 os was that of Rigoberta Menchú of Guatemala, who won the Nobel Peace Prize in 1992 but whose testimony also sparked controversy about truth; for an excellent discussion, see Arias, The Rigoberta Menchú Controversy, which responded to Stoll, Rigoberta Menchú and the Story of All Poor Guatemalans; for the testimonial text in its influential English-language edition, see Menchú, I, Rigoberta Menchú.

16. Franco, The Decline and Fall, 201.

17. In my research on the Chilean case of democratic transition, one of the central conclusions I arrived at is that conflictive synergies between civil society actors and state actors proved crucial for cumulative advance on issues of truth, justice, and human rights memory but that the creative synergistic moments were transitory. During this up-and-down history, civil society actors often carried the burden of pressing the memory question and insisting on widening human rights work rather than settling for a point of closure. For the Chilean case and related comparative and international perspectives, see Stern, Reckoning with Pinochet, 360-383. For suggestive recent research that documents widening circles of social actors who resort to artistic technique, irrespective of recognition of their work as "art," to push memory issues and awareness into the public domain even as relations with state actors remain problematic, see Stites Mor, Transition Cinema; Feld and Stites Mor, El pasado que miramos; Jelin and Longoni, Escrituras, imágenes y escenarios ante la represión.

18. For theorized discussion of memory struggles as labor opposing distinct selective frameworks of meaning, and thereby binding the making of memory with the making of silence, from overlapping but somewhat distinct perspectives, see Jelin, Los trabajos de la memoria, and Stern, Remembering Pinochet's Chile; and for perspective on silence as a form of communication, Jaworski, Silence.

19. On silences within intimate familial and intergenerational contexts, see, aside from the sources in n. 18 here, Jelin and Kaufman, Subjetividad y figuras de la memoria, 
esp. Kaufman, "Lo legado y lo propio"; for silence as personal defense against humiliation, in the aftermath of torture and sexualized violence, as a major finding within the Chilean truth commission process on political prison and torture, Stern, Reckoning with Pinochet, 293-297; on the self divided between "deep" life and "normal" everyday life, I am greatly indebted to Delbo, Days and Memory, and the brilliant elaboration inspired by Delbo in Langer, Holocaust Testimonies.

20. González, Unveiling Secrets of War in the Peruvian Andes; for other pioneering microstudies, see del Pino, "Uchuraccay"; Gamarra Carrillo, Resiliencia social y cambio en comunidades campesinas afectadas por conflicto armado interno; Heilman, Before the Shining Path; La Serna, The Corner of the Living; Theidon, Entre prójimos; and for microlevel research from urban and art history perspectives, respectively, Tamayo, "ANFASEP y la lucha por la memoria de sus desparecidos (1983-200o)"; Ulfe, Cajones de la memoria. On "resistant adaptation" as a lens for considering community stances toward Shining Path, see Stern, Shining and Other Paths, 119-257, esp. Degregori, "Harvesting Storms," and del Pino, "Family, Culture, and 'Revolution"'; also Degregori, How Difficult It Is to Be God, chap. 5.

21. Hite, Politics and the Art of Commemoration, esp. 42-62; see also Drinot, "For Whom the Eye Cries," and Milton, "Defacing Memory."

22. On the memory question in the Asháninka context, see Villapolo Herrera, "Senderos del desengaño"; and for broader contexts of expansion of war into the central sierra and selva regions north of Ayacucho on the one hand and as far south as Puno on the other, Manrique, "The War for the Central Sierra," and Rénique, "Apogee and Crisis of a 'Third Path'." 


\section{B I B L IO G R A PHY}

Abu-Lughod, Lila. “Writing against Culture." In Recapturing Anthropology, edited by Richard Fox, 137-162. Santa Fe: School of American Research Press, 1991.

Acevedo, Juan. Para hacer historietas. Originally published 1978. Madrid: Editorial Popular, 1984 .

Adams, Jacqueline. "Art in Social Movements: Shantytown Women’s Protest in

Pinochet's Chile." Sociological Forum 17, no. 1 (2002): 21-56.

Adorno, Theodor W. Can One Live after Auschwitz? A Philosophical Reader. Edited by Rolf

Tiedemann. Translated by Rodney Livingstone. Stanford: Stanford University Press, 2003.

- Gesellschaftstheorie und Kulturkritik. Frankfurt am Main: Suhrkamp Verlag, 1975.

- Minima Moralia: Reflections from a Damaged Life. Translated by E. F. N. Jephcott.

Originally published 1951. London: Verso, 1978.

—. Negative Dialectics. Translated by E. B. Ashton. Originally published 1966. New York: Continuum Press, 1973.

—. Prisms. Translated by Samuel and Shierry Weber. Cambridge, Mass.: Miт Press, 1981.

Agosín, Marjorie. Tapestries of Hope, Threads of Love: The "Arpillera" Movement in Chile, 1974-1994. Santa Fe: University of New Mexico Press, 1996.

Aguirre, Carlos. “¿De quién son estas memorias? El archivo de la Comisión de la Verdad y Reconciliación del Perú.” Jahrbuch fur Geschichte Lateinamerikas (Köln, Germany) 46 (2009): 135-165.

Allen, Catherine. The Hold Life Has: Coca and Cultural Identity in an Andean Community. Washington D.C.: Smithsonian Institution Press, 2002.

A'ness, Francine. "Resisting Amnesia: Yuyachkani, Performance, and the Postwar Reconstruction of Peru." Theatre Journal 56 (2004): 395-414.

Ansión, Juan. Anhelos y sinsabores: Dos décadas de políticas culturales del estado peruano. Lima: GREDES, 1986.

. "Presentación." In Imágenes y realidad a la conquista de un viejo lenguaje, edited by Jenifer Bonilla, Hugo Carillo, Nelly Plaza, and Liliana Prado, 13-25. Peru: Comisión Coordinadora Nacional del Concurso Nacional de Dibujo y Pintura Campesina, 1990. Arendt, Hannah. The Human Condition: A Study of the Central Dilemmas Facing Modern Man. Originally published 1958. Garden City, N.Y.: Doubleday Anchor, 1959. 
Arguedas, Jose María. Todas las sangres. Originally published 1964. Lima: Milla Batres, 1980.

Arias, Arturo, ed. The Rigoberta Menchú Controversy. Minneapolis: University of Minnesota Press, 2001.

Augé, Marc. Las formas del olvido. Barcelona: Editorial Gedisa, 1998.

Barrantes Segura, Rafael, and Jesús Peña Romero. "Narrativas sobre el conflicto armado interno en el Perú: La memoria en el proceso político después de la CVR." In Transformaciones democráticas y memorias de la violencia en el Perú, coordinated by Félix Reátegui Carrillo, 15-40. Lima: IDEHPUCP, 2006.

Bartov, Omer. Mirrors of Destruction: War, Genocide, and Modern Identity. New York: Oxford University Press, 2000.

Bell, John. "Rediscovering Mask Performance in Peru: Gustavo Boada, Maskmaker with Yuyachkani." The Drama Review 43, no. 3 (1999): 169-181.

Bennett, Jill. Empathetic Vision: Affect, Trauma, and Contemporary Art. Stanford: Stanford University Press, 2005.

Bernard-Donals, Michael, and Richard Glejzer. Between Witness and Testimony: The Holocaust and the Limits of Representation. Albany: State University of New York Press, 2001.

Beverley, John. "The Real Thing." In The Real Thing: Testimonial Discourse and Latin America, edited by Georg Gugelberger, 266-286. Durham, N.C.: Duke University Press, 1996.

Bickford, Louis. “Unofficial Truth Projects.” Human Rights Quarterly 29, no. 4 (2007): 994-1035.

Bilbija, Ksenija, Jo Ellen Fair, Cynthia E. Milton, and Leigh A. Payne, eds. The Art of Truth-Telling about Authoritarian Rule. Madison: University of Wisconsin Press, 2005.

Bonilla, Jenifer, Hugo Carillo, Nelly Plaza, and Liliana Prado. Imágenes y realidad a la conquista de un viejo lenguaje. Peru: Comisión Coordinadora Nacional del Concurso Nacional de Dibujo y Pintura Campesina, 1990.

Brett, Guy. Through Our Own Eyes: Popular Art and Modern History. Philadelphia: New Society, 1986.

Briceño, Ximena. "Consuming Culture: The Latin American Museum in Neoliberalism." Ph.D. diss., Cornell University, 2009.

Bueno-Hansen, Pascha. "Engendering Transitional Justice: Reflections on the Case of Peru." Journal of Peacebuilding and Development 5, no. 3 (2010): 61-74.

Burke, Peter. Eyewitnessing: The Uses of Images as Historical Evidence. Ithaca: Cornell University Press, 2001.

Burt, Jo-Marie. "Guilty as Charged: The Trial of Former Peruvian President Alberto Fujimori for Human Rights Violations." International Journal of Transitional Justice 3, no. 3 (2009): 384-405.

_. "The Paradoxes of Accountability: Transitional Justice in Peru." In Embracing Paradox: Human Rights in the Global Age, edited by Steve J. Stern and Scott Straus. Madison: University of Wisconsin Press, forthcoming. 
- Political Violence and the Authoritarian State in Peru. New York: Palgrave Macmillan, 2007 .

Cala Buendía, Felipe. "Truth in the Time of Fear: Adiós Ayacucho’s Poetics of Memory and the Peruvian Transitional Justice Process." International Journal of Transitional Justice 6, no. 2 (2012): 344-354.

Cánepa Koch, Gisela. "The Public Sphere and Cultural Rights: Culture as Action.” É-misférica 6, no. 2 (2010).

—_ "Representación social y pintura campesina: Reflexiones desde la antropología visual." In Imágenes de la tierra: Archivo de pintura campesina, compiled by Museo del Arte de San Marcos, 8-15. Lima: Museo de Arte de San Marcos, 2006.

Castrillón, Alfonso. “¿Arte popular o artesanía?” Historia y cultura 10 (1978): 15-21.

Cecconi, Ariana. "Dreams, Memory, and War: An Ethnography of Night in the Peruvian Andes." Journal of Latin American and Caribbean Anthropology 16 (2011): 401-424.

Claussen, Detlev. Theodor Adorno: One Last Genius. Translated by Rodney Livingstone. Originally published 2003. Cambridge, Mass.: Harvard University Press, 2008.

Colectivo Yuyarisun. Rescate por la memoria: Ayacucho. Lima: Colectivo Yuyarisun, Ministerio Británico para el Desarrollo International, Organización Holandesa para la Cooperación International al Desarrollo, 2004.

Collins, Cath. Post-transitional Justice: Human Rights Trails in Chile and El Salvador. University Park: Pennsylvania State University Press, 2010.

Comisión de la Verdad y Reconciliación del Perú (CVR). "Conclusiones generales del Informe final de la CVR.” Lima: Comisión de la Verdad y Reconciliación, 2003. Originally in volume 8 of the CVR, Informe final. Available at the website of the Comisión de la Verdad y Reconciliación, www.cverdad.org.pe/ifinal/conclusiones.php, accessed July 12, 2013.

- Hatun Willakuy: Versión abreviada del Informe final de la Comisión de la Verdady Reconciliación, Perú. Lima: cvR, 2004.

—. Informe final. 9 vols. Lima: Comisión de la Verdad y Reconciliación, 2003. Available at the website of the Comisión de la Verdad y Reconciliación, www.cverdad.org .pe, accessed July 12, 2013.

- Yuyanapaq. Para recordar: Relato visual del conflicto armado interno en el Perú, 1980-2000. Lima: CVR, 2003.

Comisión Permanente de Historia del Ejército del Perú. En Honor a la Verdad: Versión del Ejército sobre su participación en la defensa del sistema democrático contra las organizaciones terroristas. Comisión Permanente de Historia del Ejército del Perú: Lima, 2012.

Comité de América Latina y el Caribe para la Defensa de los Derechos de la Mujer (CLADEM). Nada personal: Reporte de derechos humanos sobre la aplicación de la anticoncepción quirúrgica en el Perú. Lima: CLADEM, 1999.

Connerton, Paul. How Societies Remember. Cambridge: Cambridge University Press, 1989.

Conquergood, Dwight. "Health Theater in a Hmong Refugee Camp: Performance, Communication, and Culture." TDR 32, no. 3 (1988): 174-208.

Contreras, Carlos. Aprendizaje del Capitalismo. Lima: IEP, 2004. 
. Maestros, mistis y campesinos en el Perú rural del siglo XX. Documento de trabajo 80. Lima: IEP, 1996.

Coronil, Fernando. “Seeing History.” Hispanic American Historical Review 84, no. 1 (2004): 1-4.

Coxshall, Wendy. "From the Peruvian Reconciliation Commission to Ethnography: Narrative, Relatedness, and Silence." Political and Legal Anthropology Review 28, no. 2 (November 2005): 203-222.

Cruvellier, Thierry. Court of Remorse: Inside the International Criminal Tribunal for Rwanda. Translated by Chari Voss. Madison: University of Wisconsin Press, 2010. Cueto, Alonso, La hora azul. Lima: Anagrama/Peisa, 2005.

Cummins, Thomas. Toasts with the Inca: Andean Abstraction and Colonial Images on Quero Vessels. Ann Arbor: University of Michigan Press, 2002.

Degregori, Carlos Iván. La década de la antipolítica: Auge y Huida de Alberto Fujimori y Vladimiro Montesinos. Originally published 2000. Lima: IEP, 2012.

- "Edilberto Jiménez: Una temporada en el infierno." Prologue to Chungui: Violencia y trazos de memoria, by Edilberto Jiménez Quispe, 13-16. Lima: Comisdeh, 2005, 2009.

—_. "Entre los fuegos de Sendero y el Ejército: Regreso de los 'pischtacos."” In Pishtacos: de verdugos a saca ojos, edited by Juan Ansión, 109-114. Lima: Tarea, Asociación de Publicaciones Educativas, 1989.

—. "Harvesting Storms: Peasant Rondas and the Defeat of Sendero Luminoso in Ayacucho." In Shining and Other Paths: War and Society in Peru, 1980-1995, edited by Steve J. Stern, 128-157. Durham, N.C.: Duke University Press, 1998.

_ . "Heridas abiertas, derechos esquivos: Reflexiones sobre la Comisión de la Verdad y Reconciliación.” In Memorias en conflicto: Aspectos de la violencia política contemporánea, edited by Raynald Belay, Jorge Bracamonte, Carlos Iván Degregori, and Jean Joinville Vacher, 75-85. Lima: Embajada de Francia en el Perú, IEP, IFEA, Red para el Desarrollo de las Ciencias Sociales en el Perú, 2004.

- How Difficult It Is to Be God: Shining Path's Politics of War in Peru, 1980-1999. Edited by Steve J. Stern. Madison: University of Wisconsin Press, 2012.

—_. "Identidad étnica, movimientos sociales y participación política en el Perú." In Democracia, etnicidad y violencia política en los países andinos, edited by Alberto Adrianzén, Jean Michel Blanquer, Ricardo Calla, Carlos Iván Degregori, Pierre Gilhodes, Patrick Husson, Jean Pierre Lavaud, Jorge León Trujillo, Rodrigo Montoya, Daniel Pécaut, Eduardo Pizzaro, and Alberto Rocha, 113-133. Lima: IFEA and IEP, 1993.

_ IEP, 2003.

—_. "La palabra y la escucha: Reflexiones sobre la Comisión de Verdad y Reconciliación." Socialismo y participación 92 (2002): 93-98.

—. Que difícil es ser Dios: Ideología y violencia política en Sendero Luminoso. Lima: El Zorro de Abajo Ediciones, 1989.

—_. El surgimiento de Sendero Luminoso: Ayacucho 1969-1979. Lima: IEP, 1990. 
Degregori, Carlos Iván, José Coronel, Ponciano del Pino, and Orin Starn, eds. Las rondas campesinas y la derrota de Sendero Luminoso. 2nd ed. Lima: IEP, 1996.

de la Cadena, Marisol. "Discriminación étnica." Cuestión de Estado 32 (November 2003): $8-9$.

- Indigenous Mestizos: The Politics of Race and Culture in Cuzco, Peru, 1919-1991.

Durham, N.C.: Duke University Press, 2000.

Delbo, Charlotte. Days and Memory. Translated by Rosette Lamont. Originally published 1985. Marlboro, Vt.: Marlboro Press, 1990.

del Pino, Ponciano. “'En busca del gobierno’: Comunidad, política y la producción de la memoria y los silencios en Ayacucho, Perú, siglo XX." Ph.D. diss., University of Wisconsin-Madison, 2008.

—_. "Family, Culture, and 'Revolution': Everyday Life with Sendero Luminoso.” In Shining and Other Paths: War and Society in Peru, 1980-1995, edited by Steve J. Stern, 158-192. Durham, N.C.: Duke University Press, 1998.

_. "Uchuraccay: Memoria y representación de la violencia política en los Andes."

In Jamás tan cerca arremetió lo lejos: Memoria y violencia política en el Perú, edited by Carlos Iván Degregori, 49-93. Lima: IEP, 2003.

del Pino, Ponciano, and Kimberley Theidon. “'Así es como vive gente’: Procesos deslocalizados y culturas emergentes." In Cultura y globalización, edited by Carlos Iván Degregori and Gonzalo Portocarrero, 183-202. Lima: Red para el desarrollo de las ciencias sociales en el Perú, 1999.

Dreifus, Claudia. “Playboy Interview: Gabriel García Márquez, A Candid Conversation with the Nobel Prize Winner about His Novels, His Friend Fidel Castro, and Life, Love, and Revolution in Latin America." Playboy 30, no. 2 (February 1983): 65-77, $172-178$.

Drinot, Paulo. The Allure of Labor: Workers, Race, and the Making of the Peruvian State. Durham, N.C.: Duke University Press, 2011.

— . "For Whom the Eye Cries: Memory, Monumentality, and the Ontologies of Violence in Peru." Journal of Latin American Cultural Studies 18, no. 1 (March 2009): 15-32.

Falconí, Carola, Edilberto Jiménez, and Giovanni Alfaro. Lluqanamarka: Llaqtanchikpa yuyariynin; Lucanamarca: Memorias de nuestro pueblo. Lima: COMISEDH, 2007.

Farmer, Sarah. "Going Visual: Holocaust Representation and Historical Method." American Historical Review 115, no. 1 (2010): 115-122.

Feld, Claudia, and Jessica Stites Mor, eds. El pasado que miramos: Memoria e imagen ante la historia reciente. Buenos Aires: Paidós, 2009.

Feld, Steven. "Wept Thoughts: The Voicing of Kaluli Memories." In South Pacific Oral Traditions, edited by Ruth Finnegan and Margaret Orbell, 85-108. Bloomington: University of Indiana Press, 1995.

Feldman, Joseph P. "Exhibiting Conflict: History and Politics at the Museo de la Memoria de ANFASEP in Ayacucho." Anthropological Quarterly 85, no. 2 (2012): 487-518.

Feldman, Shoshana, and Dori Laub. Testimony: Crises of Witnessing in Literature, Psychoanalysis, and History. New York: Routledge, 1992. 
Flam, Gila. Singing for Survival: Songs of the Lodz Ghetto, 1940-45. Chicago: University of Chicago Press, 1992.

Franco, Jean. The Decline and Fall of the Lettered City: Latin America in the Cold War. Cambridge, Mass.: Harvard University Press, 2002.

- The Modern Culture of Latin America: Society and the Artist. Originally published 1967. Baltimore: Penguin Books, 1970.

Franklin, Ruth. "The Long View: A Rediscovered Master of Holocaust Writing." The New Yorker, January 31, 2011, 74-79.

Friedlander, Saul, ed. Probing the Limits of Representation: Nazism and the "Final Solution." Cambridge: Harvard University Press, 1992.

. "Trauma, Transference and 'Working Through' in Writing the History of the Shoah." History \& Memory 4, no. 1 (Spring/Summer 1992): 39-59.

Gamarra Carrillo, Jefrey. Resiliencia social y cambio en comunidades campesinas afectadas por conflicto armado interno: El caso de las comunidades de Incaraccay y Tanquihua en la provincia de Cangallo, Ayacucho. Lima: IPEDEHP, 2010.

García, María Elena. Making Indigenous Citizens: Identities, Education, and Multicultural Development in Peru. Stanford: Stanford University Press, 2005.

García Canclini, Nestor. Hybrid Cultures: Strategies for Entering and Leaving Modernity. Minneapolis: University of Minnesota Press, 1995.

Gavilán, Lurgio. Memorias de un soldado desconocido. Autobiografía y antropología de la violencia. Lima: IEP, 2012.

Gell, Alfred. Art and Agency: An Anthropological Theory. New York: Clarendon Press, 1998.

Gibson, Nigel, and Andrew Rubin, eds. Adorno: A Critical Reader. Oxford: Blackwell, 2002.

Gillis, John R., ed. Commemorations: The Politics of National Identity. Princeton: Princeton University Press, 1996.

Glave, Luis Miguel, and Jaime Urrutia. "Radicalismo político en elites regionales, Ayacucho 1930-1956." Revista Debate Agrario 31 (2000): 1-37.

Golte, Jürgen, and Ramón Pajuelo, eds. Universos de la memoria: Aproximación a los retablos de Edilberto Jiménez sobre la violencia política. Lima: IEP, 2012.

Gómez-Barris, Macarena. Where Memory Dwells: Culture and State Violence in Chile. Berkeley: University of California Press, 2009.

Gonzáles Carré, Enrique, Jaime Urrutia, and Jorge Lévano. Ayacucho: San Juan de la Frontera. Lima: Banco de Crédito, 1997.

González Cueva, Eduardo. "The Contribution of the Peruvian Truth and Reconciliation Commission to Prosecutions." Criminal Law Forum 15 (2004): 55-66.

—. "The Peruvian Truth and Reconciliation Commission and the Challenge of Impunity.” In Transitional Justice in the Twenty-First Century: Beyond Truth versus Justice, edited by Naomi Roht-Arriaza and Javier Mariezcurrena, 70-93. New York: Cambridge University Press, 2006.

González, Olga. "Scarf of Hope as a Warm and Performative Memorial for the 
Disappeared in Peru." Anthropology News 52, no. 6 (2011), available at www .anthropology-news.org, accessed July 15, 2013.

- Unveiling Secrets of War in the Peruvian Andes. Chicago: University of Chicago Press, 2011.

Gorriti Ellenbogen, Gustavo. La batalla. Lima: Instituto de Defensa Legal, 2003.

- Sendero: Historia de la guerra milenaria en el Perú. Lima: Editorial Apoyo, 1990.

- The Shining Path: A History of the Millenarian War in Peru. Translated by Robin Kirk. Chapel Hill, N.C.: University of North Carolina Press, 1999.

Grandin, Greg, and Gilbert M. Joseph, eds. A Century of Revolution: Insurgent and Counterinsurgent Violence during Latin America’s Long Cold War. Durham, N.C.: Duke University Press, 2010.

Grandin, Greg, and Thomas Klubock. "Editors' Introduction," to special issue "Truth Commissions: State Terror, History, and Memory," Radical History Review, 97 (2006): $1-10$.

Guerin, Francis, and Roger Hallas, eds. The Image and the Witness: Trauma, Memory and Visual Culture. London: Wallflower Press, 2007.

Gugelberger, Georg, ed. The Real Thing: Testimonial Discourse and Latin America. Durham, N.C.: Duke University Press, 1996.

Hayner, Priscilla. Unspeakable Truths: Confronting State Terror and Atrocity. Originally published 2001. New York: Routledge Press, 2011.

Heilman, Jaymie Patricia. Before the Shining Path: Politics in Rural Ayacucho, 1895-1980. Stanford: Stanford University Press, 2010.

Hershberg, Eric, and Felipe Agüero. Memorias militares sobre la repression en el Cono Sur: Visions en disputa en dictadura y democracia. Madrid: Siglo XXI, 2005.

Hirsch, Marianne. The Generation of Post-Memory: Writing and Visual Culture after the Holocaust. New York: Columbia University Press, 2012.

Hite, Katherine. Politics and the Art of Commemoration: Memorials to Struggle in Latin America and Spain. London: Routledge Press, 2012.

Hofmann, Klaus. "Poetry after Auschwitz-Adorno's Dictum." German Life and Letters 58, no. 2 (April 2005): 182-194.

Huber, Ludwig. Consumo, cultura e identidad en el mundo globalizado: Estudio de caso en los Andes. Lima: IEP, 2002.

Huerta, Alex. "Incas y españoles bailando un alegre huayno: El humor en una representación teatral en los Andes." In Identidades representadas, performance, experiencias y memoria, edited by Gisela Cánepa Koch, 309-330. Lima: PUCP, 2001.

Huhn, Tom, ed. The Cambridge Companion to Adorno. New York: Cambridge University Press, 2004.

Huneeus, Alexandra. “Judging from a Guilty Conscience: The Chilean Judiciary's Human Rights Turn." Law and Social Inquiry 35, no. 1 (Winter 2010): 99-135.

Huyssen, Andreas. Present Pasts: Urban Palimpsests and the Politics of Memory. Stanford: Stanford University Press, 2003. 
Instituto de Estudios Peruanos. El retablo ayacuchano: Un arte de los Andes. Lima: IEP, 1992.

- Revista Argumentos 3, no. 4, 2009.

Isbell, Billie Jean. "Violence in Peru: Performances and Dialogues." American Anthropologist 100 (1988): 282-292.

Jäger, Lorenz. Adorno: A Political Biography. Translated by Stewart Spencer. Originally published 2003. New Haven: Yale University Press, 2004.

Jameson, Fredric. "The Politics of Utopia." New Left Review 25 (2004): 35-54.

Japanese Broadcasting Corporation (NHK). Unforgettable Fire: Pictures Drawn by Atomic Bomb Survivors. New York: Pantheon Books, 1977.

Jaworski, Adam, ed. Silence: Interdisciplinary Perspectives. Berlin: de Gruyter, 1997.

Jelin, Elizabeth, ed. Las conmemoraciones: Las disputas en las fechas "in-felices." Madrid: Siglo XXI, 2002.

- Los trabajos de la memoria. Collección Memorias de la represión, no. 1. Madrid: Siglo XXI, 2002.

- State Repression and the Labors of Memory. Translated by Judy Rein and Marcial Godoy-Anatiria. Minneapolis: University of Minnesota Press, 2003.

Jelin, Elizabeth, and Susana G. Kaufman, eds. Subjetividad y figuras de la memoria. Buenos Aires: Siglo XXI Editorial Iberoamericana, 2006.

Jelin, Elizabeth, and Victoria Langland, eds. Monumentos, memoriales y marcas territoriales. Madrid: Siglo XXI, 2003.

Jelin, Elizabeth, and Ana Longoni, eds. Escrituras, imágenes y escenarios ante la represión. Madrid: Siglo XXI, 2005.

Jiménez Quispe, Edilberto. Chungui: Violencia y trazos de memoria. Lima: Comisdeh, 2005; IEP, 2009.

Johnson, Bruce, and Martin Cloonan. Dark Side of the Tune: Popular Music and Violence. London: Ashgate, 2008.

Joseph, Gilbert M., and Daniela Spenser, eds. In from the Cold: Latin America's New Encounter with the Cold War. Durham, N.C.: Duke University Press, 2008.

Kaneko, Anne, dir. Against the Grain: An Artist's Survival Guide to Peru. 65 mins., USA: New Day Films, 2008.

Kaufman, Susana. "Lo legado y lo propio: Lazos familiares y transmisión de memorias." In Subjetividad y figuras de la memoria, edited by Elizabeth Jelin and Susana G. Kaufman, 47-71. Buenos Aires: Siglo XXI, 2006.

Keck, Margaret E., and Kathryn Sikkink. Activists beyond Borders: Advocacy Networks in International Politics. Ithaca, N.Y.: Cornell University Press, 1998.

Kelleher, Desmond. "Much More Than a Competition." Irish Migration Studies in Latin America 6, no. 2 (2008): 111-121.

Kernaghan, Richard. Coca's Gone: Of Might and Right in the Huallaga Post-Boom. Stanford: Stanford University Press, 2009.

Koch, Gertrud. "The Aesthetic Transformation of the Image of the Unimaginable: Notes on Claude Lanzmann's Shoah." October 48 (Spring 1989): 15-24. 
LaCapra, Dominick. History and Memory after Auschwitz. Ithaca: Cornell University Press, 1998.

- Writing History, Writing Trauma. Baltimore: Johns Hopkins University Press, 2001.

Lane, Jill. "Antígona and the Modernity of the Dead." Modern Drama 50, no. 4 (Winter 2007): 517-531.

—_. "Spatial Truth and Reconciliation: Peru, 2003-2004." In Telling Ruins in Latin America, edited by Michael J. Lazzara and Vicky Unruh, 135-146. New York: Palgrave Macmillan, 2009.

Langer, Lawrence. Holocaust Testimonies: The Ruins of Memory. New Haven: Yale University Press, 1991.

Laplante, Lisa J. “The Peruvian Truth Commission’s Historical Memory Project: Empowering Truth-Tellers to Confront Truth Deniers." Journal of Human Rights 64, no. 4 (2007): 433-452.

Laplante, Lisa J., and Kimberly Theidon. "Truth with Consequences: Justice and Reparations in Post-Truth Commission Peru." Human Rights Quarterly 29, no. 1 (2007): 228-250.

Larrabure, Cecilia. Ciertos vacíos: Un ensayo fotográfico sobre orfandad, violencia y memoria en el Perú. Lima: PUCP, 2007.

La Serna, Miguel. The Corner of the Living: Ayacucho on the Eve of the Shining Path Insurgency. Chapel Hill: University of North Carolina Press, 2012.

Laub, Dori. "Bearing Witness or the Vicissitudes of Listening." In Testimony: Crises of Witnessing in Literature, Psychoanalysis, and History, edited by Shoshana Feldman and Dori Laub, 57-74. New York: Routledge, 1992.

Lauer, Mirko. Crítica de la artesanía: Plástica y sociedad en los Andes peruanos. Lima: Centro de Estudios y Promoción del Desarrollo, 1982.

Lazzara, Michael J. Chile in Transition: The Poetics and Politics of Memory. Gainesville: University of Florida Press, 2006.

- ed. Luz Arce and Pinochet's Chile: Testimony in the Aftermath of State Violence. New York: Palgrave Macmillan, 2011.

LeGrand, Catherine. "Living in Macondo: Economy and Culture in a United Fruit Company Banana Enclave in Colombia." In Close Encounters of Empire: Writing the Cultural History of U.S.-Latin American Relations, edited by Gilbert M. Joseph, Catherine C. LeGrand, and Ricardo D. Salvatore, 333-368. Durham, N.C.: Duke University Press, 1998.

Lehrer, Erica, and Cynthia E. Milton. "Witnesses to Witnessing.” In Curating Difficult Knowledge: Violent Pasts in Public Places, edited by Erica Lehrer, Cynthia E. Milton, and Monica Eileen Patterson, 1-19. London: Palgrave MacMillan, 2011.

Leiby, Michele. "Digging in the Archives: The Promise and Perils of Primary Documents." Politics \& Society 37, no. 1 (2009): 75-100.

Lemlij, Moisés, and Luis Millones. Las tablas de Sarhua: Arte, violencia e historia en el Perú. Lima: SIDEA, 2004. 
Lerner Ferbres, Salomón. La rebelión de la memoria: Selección de discursos, 2001-2003. Lima: IDEHPUC, Coordinadora de derechos humanos, CEP, 2004.

Lizárraga, Karen. "El registro andino: Constuyendo un modelo proprio." In Imágenes y realidad a la conquista de un viejo lenguaje, edited by Jenifer Bonilla, Hugo Carillo, Nelly Plaza, and Liliana Prado, 213-221. Peru: Comisión Coordinadora Nacional del Concurso Nacional de Dibujo y Pintura Campesina, 1990.

Loew, Camila. "Traumatic Identity in Contemporary Catalan Testimonies." In The Image and the Witness, edited by Frances Guerin and Roger Hallas, 23-36. London: Wallflower Press, 2007.

Longoni, Ana. El Siluetazo. Buenos Aires: Adriana Hidalgo Editora, 2008.

Lutz, Ellen, and Kathryn Sikkink. "The Justice Cascade: The Evolution and Impact of Foreign Human Rights Trials in Latin America." Chicago Journal of International Law 2, no. 1 (Spring 2001): 1-33.

Macera, Paulo. "El mate de la Conquista: ¿Arte protesta?" In his Trincheras y fronteras del arte popular peruano, compiled by Miguel Pinto, 205-210. Lima: Fondo Editorial del Congreso del Perú, 2009.

Maclear, Kyo. Beclouded Visions: Hiroshima-Nagasaki and the Art of Witness. Albany: State University of New York Press, 1999.

Mallon, Florencia. "Editor's Introduction." In When a Flower Is Reborn: The Life and Times of a Mapuche Feminist, by Rosa Isolde Reuque Paillalef and edited by Florencia Mallon, 24-30. Durham, N.C.: Duke University Press, 2002.

Manrique, Nelson. El tiempo del miedo: La violencia política en el Perú, 1980-1996. Lima: Fondo Editorial del Congreso del Perú, 2002.

— . "The War for the Central Sierra." In Shining and Other Paths: War and Society in Peru, 1980-1995, edited by Steve J. Stern, 193-223. Durham, N.C.: Duke University Press, 1998.

Masiello, Francine. The Art of Transition: Latin American Culture and Neoliberal Crises. Durham, N.C.: Duke University Press, 2001.

Matos Mar, José. Desborde popular y crisis del Estado: Viente años después. Lima: Fondo Editorial del Congreso de la República, 2004.

Mayer, Enrique. "Peru in Deep Trouble: Mario Vargas Llosa's 'Inquest in the Andes' Reexamined." Cultural Anthropology, 6, no. 4 (1991): 466-504.

Menchú, Rigoberta. I, Rigoberta Menchú: An Indian Woman in Guatemala. Edited by Elisabeth Burgos-Debray. Translated by Ann Wright. Originally published 1984. London: Verso, 2009.

Méndez, Cecilia. The Plebeian Republic: The Huanta Rebellion and the Making of the Peruvian State, 1820-1850. Durham, N.C.: Duke University Press, 2005.

Méndez, Juan E. "Accountability for Past Abuses." Human Rights Quarterly 19, no. 2 (1997): 255-282.

Mendizábal, Emilio. Del sanmarkos al retablo ayacucho: Dos ensayos pioneros sobre arte tradicional peruano. Lima: Universidad Ricardo Palma e Instituto Cultural Peruano Norteamericano, 2003. 
Mendoza, Zoila. Creating Our Own: Folklore, Performance, and Identity in Cuzco, Peru. Durham, N.C.: Duke University Press, 2008.

Milton, Cynthia. "At the Edge of the Peruvian Truth Commission: Alternative Paths to Recounting the Past." Radical History Review 98 (Spring 2007): 3-33.

_ . "Curating Memories of Armed State Actors in Peru's Era of Transitional Justice." Memory Studies, forthcoming. . "Defacing Memory: (Un)tying Peru’s Memory Knots." Memory Studies 4, no. 2 (April 2011): 1-16.

—_. "Images of Truth: Art as a Medium for Recounting Peru's Internal War." A Contracorriente 6o, no. 2 (2008): 64-103.

_. "Parallel Lies? Peru's Cultural Memory Battles Go International." E-misférica 7, no. 2 (2011).

— . "Public Spaces for the Discussion of Past Violence: The Case of Peru." AntipodaRevista de Antropologia y Arqueologia (July-December 2007): 143-168.

Milton, Cynthia, and Maria Eugenia Ulfe. "Promoting Peru: Tourism and Post-Conflict Memory." In Accounting for Violence: the Memory Market in Latin America, edited by Ksenija Bilbija and Leigh Payne, 304-343. Durham, N.C.: Duke University Press, 2011. Minow, Martha. Between Vengeance and Forgiveness: Facing History after Genocide and Mass Violence. Boston: Beacon Press, 1998.

Monsiváis, Carlos. Mexican Postcards. Translated by John Kraniauskas. New York: Verso, 1997.

Montoya, Edwin. "Queja Andina." Composed by Fortunato Galindo. Recorded 1966. On Queja Andina, 33² rpm LP.

Montoya, Rodrigo, Luis Montoya, and Edwin Montoya. Urqukunapa Yawarnin: La sangre de los cerros. 2nd ed. Lima: Universidad Nacional Federico Villareal, 1998.

Moodie, Ellen. El Salvador in the Aftermath of Peace: Crime, Uncertainty and the Transition to Democracy. Philadelphia: University of Pennsylvania Press, 2010.

Morán Reyna, Pablo E. Complot contra los militares: Las falcedades de la C.V.R. Lima: AMC Editores, 2006.

Moraña, Mabel. "El Ojo que Llora: Biopolítica, nudos de la memoria y arte public en el Perú de hoy." Latinoamérica: Revista de estudios latinoamericanos 54, no. 1 (2012): $183-216$.

Morris, Leslie. “The Sound of Memory.” German Quarterly 74, no. 4 (2001): 368-378.

Müller-Doohm, Stefan. Adorno: A Biography. Translated by Rodney Livingstone. Originally published 2003. Cambridge: Polity, 2005.

Muñoz, Hortencia. "Human Rights and Social Referents: The Construction of New Sensibilities." In Shining and Other Paths: War and Society in Peru, 1980-1995, edited by Steve J. Stern, 447-469. Durham, N.C.: Duke University Press, 1998.

Museo de Arte de San Marcos. Imágenes de la tierrra: Archivo de pintura campesina. Lima: Museo de Arte de San Marcos, 2006.

Nikolopoulou, Kalliopi. "As If: Kant, Adorno, and the Politics of Poetry." MLN 121 (2006): 757-773. 
Nora, Pierre. "Between Memory and History: Les Lieux de Memoire." Representations 26 (1989): 7-24.

O'Connell, John, and Salwa Castelo-Branco, eds. Music and Conflict. Urbana: University of Illinois Press, 2010.

Ortega, Julio. Adiós Ayacucho. Lima: Mosca Azul Editores, 1986.

Pajuelo, Ramón. "Miradas del horror: La violence política en las pinturas campesinas." In Imágenes de la tierra: Archivo de pintura campesina, compiled by Museo de Arte de San Marcos, 94-111. Lima: Museo de Arte de San Marcos, 2006.

Palmer, David S. The Shining Path of Peru. New York: St. Martin's Press, 1992.

Petras, James, and Maurice Zeitlin, eds. Latin America: Reform or Revolution? A Reader. Greenwich, Conn.: Fawcett, 1968.

Poole, Deborah, and Geraldo Rénique. Peru: Time of Fear. London: Latin American Bureau, 1992.

Poole, Deborah, and Isaías Rojas-Pérez. "Memories of Reconciliation: Photography and Memory in Postwar Peru." E-misférica 7, no. 2 (2011).

Portocarrero, Gonzalo. Razones de sangre: Aproximaciones a la violencia política. Lima: Pontificia Universidad Católica del Perú, 1998.

Portocarrero, Gonzalo, and Patricia Oliart. El Perú desde la escuela. Lima: IAA, 1989.

Programa de las Naciones Unidas para el Desarrollo (PNUD). La Provincia de Víctor Fajardo en Ayacucho: Información para el desarrollo humano. Lima, Peru: PNUD, 2006.

Quijano, Aníbal. “Colonialidad del poder, eurocentrismo y América Latina.” In Globalización y diversidad cultural: Una mirada desde América Latina, edited by Ramón Pajuelo and Pablo Sandoval, 228-281. Lima: IEP, 2004.

Rabe, Stephen G. The Killing Zone: The United States Wages Cold War in Latin America. New York: Oxford University Press, 2012.

Razetto, Mario. Don Joaquín: Testimonio de un artista popular andino. Lima: Instituto Andino de Artes Populares, 1982.

Reátegui Carrillo, Félix. "Violencia y ficción: Mirar a contraluz." In Toda la sangre: Antología de cuentos peruanos sobre la violencia política, edited by Gustavo Faverón Patriau, 429-449. Lima: Grupo Editorial Matalamanga, 2006.

Regalado de Hurtado, Liliana. Clío y mnemósine: Estudios sobre historia, memoria y pasado reciente. Lima: Fondo Editorial del PUCP, 2007.

Rénique, Gerardo. “'People’s War,' 'Dirty War': Cold War Legacy and the End of History in Postwar Peru." In A Century of Revolution: Insurgent and Counterinsurgent Violence during Latin America's Long Cold War, edited by Greg Grandin and Gilbert M. Joseph, 309-337. Durham, N.C.: Duke University Press, 2010.

Rénique, José Luis. "Apogee and Crisis of a 'Third Path': Mariateguismo, 'People’s War,' and Counterinsurgency in Puno." In Shining and Other Paths: War and Society in Peru, 19801995, edited by Steve J. Stern, 307-338. Durham, N.C.: Duke University Press, 1998.

—. La batalla por Puno: Conflicto agrario y nación en los Andes peruanos, 1866-1995. Lima: IEP, 2004.

. La voluntad encarcelada: Las "luminosas trincheras de combate" de Sendero Luminoso del Perú. Lima: IEP, 2003. 
Reuque Paillalef, Rosa Isolde. When a Flower Is Reborn: The Life and Times of a Mapuche Feminist. Edited by Florencia Mallon. Durham, N.C.: Duke University Press, 2002. Reyes, Adelaida. "Asymmetrical Relations: Conflict and Music as a Human Response." In Music and Conflict, edited by John O'Connell and Salwa Castelo-Branco, 126-138. Urbana: University of Illinois Press, 2010.

- Songs of the Caged, Songs of the Free. Philadelphia: Temple University Press, 1999.

Riaño Alcalá, Pilar, and Erin Baines, eds. "Transitional Justice and the Everyday: Micro-Perspectives of Justice and Social Repair," special issue for International Journal of Transitional Justice, 6, no. 3, 2012.

Richard, Nelly. Fracturas de la memoria: Arte y pensamiento crítico. Buenos Aires: Siglo XXI Editores Argentina, 2007.

Ritter, Jonathan. "Complementary Discourses of Truth and Memory: The Peruvian Truth Commission and Canción Social Ayacuchana." In Music Politics, and Violence, edited by Susan Fast and Kip Pegley, 197-222. Middletown, Conn.: Wesleyan University Press, 2012.

- "Siren Songs: Ritual and Revolution in the Peruvian Andes." British Journal of Ethnomusicology 11, no. 1 (2002): 9-42.

We Bear Witness with Our Song: The Politics of Music and Violence in the Peruvian Andes. Oxford University Press, forthcoming.

Ritter, Jonathan, and Martin Daughtry, eds. Music in the Post-9/11 World. New York: Routledge Press, 2007.

Rojas, Isaías. "Para comprender Putis y Cabitos: Sueño con serpientes.” Ideele 187 (2008): 77-82.

Rossell, Luis, Alfredo Villar, and Jesús Cossio. Rupay: Historias de la violencia en el Perú. Lima: Contracultura, 2008.

_Rupay: Historias de la violencia política en Perú, 1980-1984. Madrid: La Oveja Roja, 2009.

Rothberg, Michael. Multidirectional Memory: Remembering the Holocaust in the Age of Decolonization. Stanford: Stanford University Press, 2009.

Rowe, William, and Vivian Schelling. Memory and Modernity: Popular Culture in Latin America. New York: Verso, 1991.

Rubio Zapata, Miguel. El Cuerpo Ausente. Lima: Grupo Cultural Yuyachkani, 2008.

Sánchez, Gonzalo, and María Elvira Escallón. "Memoria, imagen y duelo: Conversaciones entre una artista y un historiador." Análisis Político 20, no. 60 (2007): 60-9o.

Sánchez, Juan Martín. "Hatun Willakuy, importancia del relato en la política: Comentarios al Informe Final de la Comisión de la Verdad y Reconciliación del Perú." Nueva Sociedad 197 (May-June 2005): 54-68.

Saona, Margarita. "The Knowledge That Comes from Seeing: Yuyanapaq and the Peruvian Truth and Reconciliation Commission." In Human Rights and Latin American Cultural Studies, edited by Ana Forcnito and Fernando Ordóñez, 210-227. Hispanic Issues On Line. Vol. 4.1, 2009.

Scarritt, Arthur. "The Rattle of Burnt Bread: Indigenous Immobilization and Land Loss 
in the Peruvian Highlands, 1982-2003." Ph.D. diss., University of WisconsinMadison, 2008.

Scarry, Elaine. The Body in Pain: The Making and Unmaking of the World. New York: Oxford University Press, 1985.

Schapp, Andrew. "Guilty Subjects and Political Responsibility: Arendt, Jaspers and the Resonance of 'The German Question' in Politics of Reconciliation.” Political Studies 49, no. 4 (2001): 749-766.

Servicios Educativos Rurales (SER). Ayacucho, informe final 1980-2000: Una compilación del Informe final de la Comisión de la Verdad y Reconciliación. Lima: Oxfam-DFID and SER, 2003.

- Rescate por la memoria, Ayacucho: Canción, poesía, narración, historieta, fotografía, ensayo, y dibujo pintado. Lima: SER and Oxfam-DFID, 2005.

- Rescate por la memoria, Huancavelica: Canción, dibujo pintado, historieta, fotografía, narración y poesía. Lima: SER and Oxfam-DFID, 2005.

—. Rescate por la memoria, Sacsamarca: Trabajos presentados en el II Homenaje a las Víctimas de la Violencia Política, Mayo 2004. Lima: SER, 2005.

Sikkink, Kathryn. The Justice Cascade: How Human Rights Prosecutions Are Changing World Politics. New York: Norton, 2011.

Sontag, Susan. Regarding the Pain of Others. New York: Picador, 2003.

Spivak, Gayatri. "Can the Subaltern Speak?" In Marxism and the Interpretation of Culture, edited by Cary Nelson and Lawrence Grossberg, 271-313. Urbana: University of Illinois Press, 1988.

Stern, Steve J. "Beyond Enigma: An Agenda for Interpreting Shining Path and Peru, 1980-1995." In Shining and Other Paths: War and Society in Peru, 1980-1995, edited by Steve J. Stern, 1-9. Durham, N.C.: Duke University Press, 1998.

_ "De la memoria suelta a la memoria emblemática: Hacia el recordar y el olvidar como proceso histórico (Chile, 1973-1998)." In Memoria para un nuevo siglo: Chile, miradas a la segunda mitad del siglo XX, edited by Mario Garcés, Pedro Milos, Myriam Olguin, Julio Pinto, Maria Teresa Rojas, and Miguel Urrutia, 11-33. Santiago: Ediciones LOM, 2000.

"Las paradojas de la verdad: Peru, Chile y sus comisiones de verdad en perspectiva comparada." Presentation at the V Aniversario de la entraga del Informe final de la CVR, Lima, August 19, 2008.

Reckoning with Pinochet: The Memory Question in Democratic Chile, 1989-2006. Durham, N.C.: Duke University Press, 2010.

- Remembering Pinochet's Chile: On the Eve of London. Durham, N.C.: Duke University Press, 2004.

- Shining and Other Paths: War and Society in Peru, 1980-1995. Durham, N.C.: Duke University Press, 1998.

Stites Mor, Jessica, ed. Human Rights and Transnational Solidarity in Cold War Latin America. Madison: University of Wisconsin Press, 2013.

Transition Cinema: Political Filmmaking and the Argentine Left since 1968. Pittsburgh: University of Pittsburgh Press, 2012. 
Stoll, David. Rigoberta Menchú and the Story of All Poor Guatemalans. Boulder, Colo.: Westview Press, 1999.

Strassler, Karen. "Children as Witnesses of History in Post-Suharto Indonesia." Visual Anthropology Review 22, no. 2 (2006): 53-70.

Tamayo, Ana María. "ANFASEP y la lucha por la memoria de sus desparecidos (19832000)." In Jamás tan cerca arremetió lo lejos: Memoria y violencia política en el Perú, edited by Carlos Iván Degregori, 95-134. Lima: IEP, 2003.

Tate, Winifred. Counting the Dead: The Culture and Politics of Human Rights Activism in Colombia. Berkeley: University of California Press, 2007.

Taylor, Diana. The Archive and the Repertoire: Performing Cultural Memory in the Americas. Durham, N.C.: Duke University Press, 2003.

Taylor, Lewis. Shining Path: Guerrilla War in Peru's Northern Highlands, 1980-1997. Liverpool, England: Liverpool University Press, 2006.

Theidon, Kimberly. "Disarming the Subject: Remembering War and Imagining Citizenship in Peru." Cultural Critique 52 (2003): 67-87.

_Entre prójimos: El conflicto armado interno y la política de la reconciliación en el Perú. Lima: IEP, 2004.

"Gender in Transition: Common Sense, Women, and War." Journal of Human Rights 6 (2007): 453-478.

- Intimate Enemies: Violence and Reconciliation in Peru. Philadelphia: University of Pennsylvania Press, 2012.

Todd, Molly. Beyond Displacement: Campesinos, Refugees, and Collective Action in the Salvadoran Civil War. Madison: University of Wisconsin Press, 2010.

Turino, Thomas. Moving Away from Silence: Music of the Peruvian Altiplano and the Experience of Urban Migration. Chicago: University of Chicago Press, 1993.

"The State and Andean Musical Production in Peru." In Nation-States and Indians in Latin America, edited by Greg Urban and Joel Sherzer, 259-285. Austin: University of Texas Press, 1991.

Ubilluz, Juan Carlos, Alexandra Hibbet, and Víctor Vich, eds. Contra el sueño de los justos: La literatura peruana ante la violencia política. Lima: IEP, 2009.

Ulfe, María Eugenia. Cajones de memoria: La historia reciente del Perú en los retablos andinos. Lima: Fondo editorial de la PUCP, 2011.

"Reflexiones sobre los usos del testimonio en la esfera pública peruana." In Mirando la esfera pública desde la cultura en el Perú, edited by Gisela Cánepa and María Eugenia Ulfe, 208-212. Lima, CONCYTEC, 2006.

Urbano Rojas, Jesús, and Pablo Macera. Santero y caminante. Lima: Editorial Apoyo, 1992.

Van Alphen, Ernst. Caught by History: Holocaust Effects in Contemporary Art, Literature, and Theory. Stanford: Stanford University Press, 1997.

Vergara, Abilio. "La memoria de la barbarie en imágenes." In Chungui: Violencia y trazos de memoria, by Edilberto Jiménez Quispe, 17-38. Lima: Comisdeh, 2005.

La tierra que duele de Carlos Falconí: Cultura, música, identidad y violencia en Ayacucho. Ayacucho: UNSCH, 2010. 
Vergara, Abilio, and Chalena Vásquez. ¡Chayraq! Carnaval ayacuchano. Ayacucho: Centro de Desarrollo Agropecuario de Ayacucho, 1988.

_ Ranulfo, El Hombre. Ayacucho: Centro de Desarrollo Agropecuario de Ayacucho, 1990.

Vich, Víctor. El caníbal es el otro: Violencia y cultura en el Perú contemporáneo Lima: IEP, 2002.

—_. "Lava la bandera." In Escrituras, imágenes y escenarios ante la represión, edited by Elizabeth Jelin and Ana Longoni, 27-30. Madrid: Siglo XXI, 2005.

Villapolo Herrera, Leslie. "Senderos del desengaño: Construcción de memorias, identidades colectivas y proyectos de futuro en una comunidad asháninka.” In Jamás tan cerca arremetió lo lejos: Memoria y violencia política en el Perú, edited by Carlos Iván Degregori, 135-173. Lima: IEP, 2003.

Weber, Samuel M. "Translating the Untranslatable." Preface to Theodor W. Adorno, Prisms, translated by Samuel and Shierry Weber, 9-15. Cambridge, Mass.: Miт Press, 1981.

Weismantel, Mary J. Cholas and Pishtacos: Stories of Race and Sex in the Andes. Chicago: University of Chicago Press, 2001.

Weissert, Markus. "Entre dos fuegos-Iconografía y narrativa de las 'Casas de Memoria' en Ayacucho." Unpublished manuscript.

Westad, Odd Arne. The Global Cold War: Third World Interventions and the Making of Our Times. New York: Cambridge University Press, 2007.

Wilde, Alex. "Irruptions of Memory: Expressive Politics in Chile's Transition to Democracy." Journal of Latin American Studies 31, no. 2 (1999): 473-50o.

Wilson, Richard. The Politics of Truth and Reconciliation in South Africa: Legitimizing the Post-Apartheid State. Cambridge: Cambridge University Press, 2001.

Wright, Thomas C. State Terrorism in Latin America: Chile, Argentina, and International Human Rights. Lanham, Md.: Rowman \& Littlefield, 2007.

Yezer, Caroline. "Anxious Citizenship: Insecurity, Apocalypse and War Memories in Peru's Andes." Ph.D. diss., Duke University, 2007.

"Who Wants to Know? Rumors, Suspicions, and Opposition to Truth-Telling in Ayacucho." Latin American and Caribbean Ethnic Studies 3, no. 3 (2008): 271-289.

Young, James. At Memory's Edge: After-Images of the Holocaust in Contemporary Art and Architecture. New Haven: Yale University Press, 2000.

— The Texture of Memory: Holocaust Memorials and Meaning. New Haven: Yale University Press, 1994.

Youngers, Coletta. Violencia política y sociedad en el Perú: Historia de la Coordinadora Nacional de Derechos Humanos. Lima: IEP, 2003.

Zalaquett, José. "Balancing Ethical Imperatives and Political Constraints: The Dilemma of New Democracies Confronting Past Human Rights Violations." Hastings Law Journal 43, no. 6 (August 1992): 1425-1438.

Zelizer, Barbie. Visual Culture and the Holocaust. New Brunswick: Rutgers University Press, 2001. 
CONTRIBUTORS

RiCARdo Caro CÁrdenas holds a degree in sociology from the Pontificia Universidad Católica del Perú, and is presently completing his Master's in history at the Universidad Nacional Mayor de San Marcos on the internal war in Huancavelica. He was a member of the Historical Memory team of the Peruvian Truth and Reconciliation Commission and participated in the Rescate por la Memoria projects and with NGOs specializing in human rights, including the Servicios Educativos Rurales.

JESÚs COSSIO has been drawing and editing comics for over a decade. He has published in several Latin American and Peruvian magazines and has participated in the creation of two books that deal with human rights violations during the Peruvian internal conflict, Rupay: historias gráficas sobre la violencia política, 1980-1984 (2008, 2009), as coauthor, and Barbarie: Comics sobre la violencia política, 1985-1990 (2010), as author. He has been invited to exhibit and present at the comic festivals Viñetas con altura, 1990 (La Paz), and Viñetas sueltas, 2009 and 2010 (Buenos Aires).

PONCIANO DEL PINO has a Ph.D. in history from the University of Wisconsin-Madison, and leads the Grupo de Memoria at the Instituto de Estudios Peruanos. He has conducted extensive field research with survivors of the war that convulsed the Ayacucho region and he is the author of several publications about memory, violence, and reconstruction, including the coedited volumes Las rondas campesinas y la derrota de Sendero Luminoso (1996), and Luchas locales, comunidades e identidades (2002), and Etnografías de la violencia: Ayacucho pasado y presente (2013).

Cynthia M. GARzA is an anthropologist with a Ph.D. from the Stone Center for Latin American Studies at Tulane University. Her dissertation work examined creole peñas, performance spaces that function as archive and sanctuary for a community striving to preserve its cultural identity in a changing city, Lima. She has also published research on the New Orleans Garifuna community during its time in exile after Hurricane Katrina. Both projects consider urban landscapes in flux, the government's inability to respond to such rapid changes, and local culture in transit. Garza teaches cultural anthropology and Latin American studies at Loyola University in New Orleans.

EDILBERTO JÍMENEZ QUISPE is a journalist and anthropologist trained at the Universidad Nacional de San Cristóbal de Huamanga, Ayacucho. He is one of Peru's most renowned 
retablo makers, having won several prizes. Jiménez has participated in conferences in England, Germany, and Japan, and his retablos have been exhibited in the United States, Spain, France, Argentina, Chile, Ecuador, Colombia, and Mexico. He is director of the journal Retablo: Arte y Cultura. From 2002-2003, Jiménez was a member of the Central-South team of the Peruvian Truth and Reconciliation Commission. He is the author of Chungui: Violencia y trazos de memoria (2005, 2009), and coauthor of Lluqanamarka: Llaqtanchikpa yuyariynin, Lucanamarca: Memorias de nuestro pueblo (2007), and Artesanía de Ayacucho (1987). He was a principal protagonist in the documentary film Chungui: Horror sin lágrimas (2009). He is presently a member of the advisory committee to the NGo Apoyo para la Paz del Instituto de Estudios Peruanos-Ayacucho.

CYNTHiA E. MiLton works on history in the Andes, in particular on historical representations of violence in contemporary Peru and perceptions of poverty in colonial Ecuador. She is the author of The Many Meanings of Poverty: Colonialism, Social Compacts, and Assistance in Eighteenth-Century Ecuador (2007), winner of the 2007 Bolton-Johnson Prize, a coeditor of The Art of Truth-Telling about Authoritarian Rule (2005), and coeditor of Curating Difficult Knowledge: Violent Pasts in Public Places (2011). Her current research is on art in the aftermath of violence. She is an associate professor and Canada Research Chair in Latin American history in the Department of History at the Université de Montréal, and recipient of the Experienced Researcher Fellowship of the Alexander von Humboldt Foundation.

JONATHAN RITTER is associate professor of music at University of California, Riverside. An ethnomusicologist specializing in the indigenous and Afro-Hispanic music of the Andean region, he is coeditor with Martin Daughtry of Music in the Post-9/11 World (2007) and author of We Bear Witness with Our Song: The Politics of Music and Violence in the Peruvian Andes (2014).

LUIS ROSSELL is a cartoonist and editor. In addition to Rupay: Historias gráficas sobre la violencia política, 1980-1984 (2008, 2009), he has coauthored several books of social criticism and has collaborated in diverse media. Currently he makes political humor graphics in "El Otorongo" and in the magazine Ideele.

steve J. stern is the Alberto Flores Galindo and Hilldale Professor of History at the University of Wisconsin-Madison, where he researches and teaches Latin American history. Among his books are Shining and Other Paths: War and Society, 1980-1995 (1998), and Reckoning with Pinochet: The Memory Question in Democratic Chile, 1989-2006 (2010), both published by Duke University Press. Major honors include the Bolton-Johnson Prize for Battling for Hearts and Minds: Memory Struggles in Pinochet's Chile, 1973-1988 (2006), and election to the American Academy of Arts and Sciences.

MARÍA EUGENIA ULFE is an anthropologist working on memory, performance, and political violence in the Andes. She is a professor in the Department of Social Sciences and academic coordinator of the Anthropology Program at the Pontificia Universidad Católica 
del Perú. Her most recent book is Cajones de memoria: La historia reciente del Perú en los retablos andinos (2011), and is author of "¿Y después de la violencia que queda? Víctimas, ciudadanos y reparaciones en el contexto post-CVR en el Perú" (CLACso, Buenos Aires, 2013). She is presently working on memory, citizenship, and reparations in Lucanamarca and Huancasancos.

víctor vich is a professor of literature at the Pontificia Universidad Católica del Perú, a principal investigator in the Instituto de Estudios Peruanos, and a former Guggenheim Fellow. He is the author of several books, including El discurso de la calle: Los cómicos ambulantes y las tensiones de la modernidad en el Perú (2001) and El caníbal es el otro: Violencia y cultura en el Perú contemporáneo (2002) and coeditor of Contra el sueño de los justos (2009). His current work engages art, violence, and politics in contemporary Peru.

ALFRedo villar studied linguistics and literature at the Pontificia Universidad Católica del Perú. He has published fiction and poetry and coauthored Rupay: Historias gráficas sobre la violencia política, 1980-1984. He has participated in conferences and exhibitions on Amazonian art and is currently working on a book about Amazonian painting with Christian Bendayán. 



\section{N D E X}

Abu-Lughod, Lila, 220-221, $250 n 7$

Acevedo, Juan, 31n67, 68n5

Adíos Ayacucho (Farewell Ayacucho), 1-2, 25n1, 200

Adorno, Theodor, 2, 23, 25n5, 25-26n6, 258-261, 263, 271, 274nn5-8

Alianza Popular Revolucionaria Americana (American Popular Revolutionary Alliance; APRA), 10-11, 163, 189-190

Allen, Catherine, 122n38, 122n4O

Amazon (region), 9, 32n85, 72nn71-72, 118, 198, 200, 211, 270

American Popular Revolutionary Alliance. See Alianza Popular Revolucionaria Americana

Amnesty, 5-6, 12-13, 3on57

Ancash (department), 8, 41, 67, 96

Andean region, 182, 203, 208, 224, 237, 244, 266; art and music from, 31n66, 53, 106-107, 115-118, 156, 162, 218, 221-222, 244, 231-233, 251n12, 251n15, 252n17, 253n34; cultural significance of, 58, 113, 121n29, 122n4O, 175n2, 197-200, 211-213, 269-270; violence against, 4, 213

Ansión, Juan, 68n1o, 68n17, 69n18, $120 n 16$

APRA. See Alianza Popular Revolucionaria Americana

Apurímac (department), 7, 8, 13, 75
Apurímac-Ene River Valley (VRAE), 13, $30 n 60$

Arendt, Hannah, 128, 258, 274n5

Argentina, 2, 3, 30-31n65, 42, 255-256, $262,272-273$

Arguedas, Jose María, 120n5, $120 n 9$

Arias, Arturo, 32n78, 275n15

Armed forces (state), 73n77, 98-99, 101n12, 181-182, 268-270, 272-273n2; artistic depictions of, 43-44, 47-51, 53-54, 59-6o, 66, 72n75, 73n9o, 74n95, 88-91, 96-99, 112-113, 115, 131, 153-154, 158-159, 162-167, 171-173, 188, 193-194, 201-214, 220-222, 243; defense of their actions, 27n31, 29n43, 33n94, 33-34n95, 34ng6, 130; memories, 9, 24, 29n43, 33n94, 33-34ng5. 34ng6, 269; responsibility of, 5, 7, 28n39, 29n42, 29n42, 29-3on48, 44, 47-48, 57, 6o-61, 121-122n32, 13o-131, 138ng, 199-200, 211-212, 218, 230, $238,242-243,256,262$; sinchis (special division of police), 58-59, 88-89, 9091; 101n15, 139, 145. See also Japanese Embassy hostage crisis; Police forces Art, arpilleras (picture appliqués), 2, 16, 26n1o, 32n73; contests/competitions, $2,19,37-74,197-215,264$; defacement, 11, 13-14, 23, 24, 3on55, 269270; definitions of, 16, 255; exhibits, 
Art (continued)

$12,15,22,31 n 67,120 n 5$; fine vs. folk, 16, 20, 31n66, 42, 66, 69n29, 104, 107109, 111-119, 121n25, 123n49, 155-156, 223-224, 263-265; and human rights, 26n1o, 39-41; interpretations/ criticisms of, 22, 166; mates burilados (painted gourds), 31n66, 40, 44; memorial, 2, 12; protest, 2, 15, 31nn6667; provoking debate/discussion, 1819, 23, 257-26o; questioning/mistrust of, 32n75; reception of, 22, 171-174, 226; as record, 2-3, 26n18; retablos as 112-116, 251n8; statistics, 6o, 68n12, 71n48, 71nn51-52, 72-73n76; statistics of participants, 53, 57-58; tablas (painted panels from Sarhua), 15, 32n72, 4O, 120n4, 139, 15o, 251n8, 269; as testimony, 15, 17, 20-21, 41-44, 65-67, 248-249; as witness, 3, 268270. See also Cinema; Comic strips; Drawings; Literature; Performance; Song

Artist(s), 31n67, 32n72, 33n86, 33n88; awards, 11, 40-41, 68n15, 71n 47, 108109, 111, 121n24, 121n26, 127, 224, 262, 274-275n12; in response to atrocity, $16,19-20,22,255,260-263,270-271$; intent, 2, 18-21, 23-25, 53-6o, 66-67, 69nn21-22, 69n25, 7on31, 109-112, $116-119,183-184,198,214,220-221$, 236, 258-267; statistics, 121n23; as survivor/witness, 18-19, 22, 33n86, 48-51, 63, 66, 69n21

Asháninka, 32-33n85, 211, 215n20, 270, 276n22

Asociación de Servicios Educativos Rurales (Association of Rural Educational Services; SER), 38-39, 41, 49, 51, 55-56, 62, 64-65, 67nn2-3, 68n4, 68n6, 69n19, 7on41, 7onn44-46, 71n48, 71nn51-52, 71n54, 71n56, 71n59, 72n7o, 73n81, 73n84, 73nn87-88, 73nn9o-91, 194n6, 194nn9-10, 195n17. See also Colectivo Yuyarisun Asociación Nacional de Familiares de Secuestrados, Detenidos y Desaparecidos del Perú (anfaser), 13, 276n2o

Association of Rural Educational Services. See Asociación de Servicios Educativos Rurales

Audiencias públicas (public hearings). See Comisión de la Verdady Reconciliación

Authoritarianism, 2-4, 6-7, 25n2, 26n1o, 26n2o, 29n44, 103, 110, 112, 206, 224, 255, 262

Auschwitz. See Holocaust

Ayacucho (city, a.k.a. Huamanga), 12, 19, 21, 33n86, 50, 52-53, 57, 6o, 61, 67, 71n47, 72n67, 73n79, 75, 96, 103, 109110, 119, 12on1, 122n44, 153, 158-175, 184, 188, 202, 218

Ayacucho (department), 1, 7, 8, 15, 19$22,37-39,43-44,48,52,58,61,75^{-}$ 76, 80, 103-104, 106, 110, 112, 117, 120n1, 122n34, 122n38, 130-131, 139, 153-175, 179, 183-184, 186, 192, 199-204, 217-253, 264, 267, 268, 270, 276n 22

Barrio Altos killing, 5

Belaúnde Terry, Fernando, 4, 7, 85, 129, 141, 169, 237

Bennett, Jill, 33n89, 69n22, 69n28

Blue Hour, The. See hora azul, La

Boada, Gustavo, 198-199, 214n5

Bolivia, 8, 252n17

Bonilla, Jenifer, 68nn7-8, 68n10, 68n12, $68 \mathrm{n} 14,68 \mathrm{n} 16,7 \mathrm{on} 31$ 
Brazil, 8, 256, 262, 272-273n2

Brett, Guy, 26n16, 69n24

Burt, Jo-Marie, 27n27, 29n47, 30n57

Bustamante, Alicia, 107-109

Cabitos, 66

Cajamarca (department), 8, 156, 187

Campo de Marte (Champs de Mars), 23, 233, 234

Cánepa Koch, Gisela, 16, 31n69, 68n11, 69n3o, 7on35, 192, 195n17

Carillo, Hugo, 68nn8-7, 68n10, 68n12, 68n14, 68n16, 7on31

casa rosada, La (The Pink House), 154, 165,166

Castrillón, Alfonso, 109, 120nn19-20

Cecconi, Ariana, 43-44, 7on32, 7on34, 71061

Chalina de Esperanza (Scarf of Hope), 12, 3on53

Chavín de Huántar operation. See Japanese Embassy hostage crisis

Chile, 2-3, 4, 8, 16, 30-31n65, 32n73, 202, 204-205, 207-208, 224, 255$256,261,262,272-273 \mathrm{n} 2,275 \mathrm{n} 17$, 275-276n19

Chungui, 21, 22, 71n61, 75-102, 251n8, 266

Church, 6, 11, 169

Chuschi, 21, 139, 180

Cinema, 15, 17, 23, 24, 154-157, 164, 264. See also Ortega Matute; Palito; individual film names

Clothing, 12, 77, 83, 93, 95, 97, 187, 200, 204, 209, 210, 211-213, 215nn2O-21

Coca-producing regions, $13,25 \mathrm{n} 2$, 30n6o Colectivo Yuyarisun (Memory Contest), 37-39, 45-47, 49-50, 59, 67nn1-3, 69n26, 7onn37-40, 7onn42-43, 71n48, 71n5o, 71n63, 72n65, 72nn68-69, 72n74, 73n78, 73n8o, 73n83, 73nn8586, 73n89, 74ng6

Collins, Cath, 26n19, 273n3

Colchado Lucio, Oscar, 201

Colombia, 3, 8, 42, 256

Comic strips (historietas and books), 20, 38-39, 47-52, 54, 57, 65, 67n2, 68n5, 71n63, 73n88, 139-151, 264-266

Comisión de la Verdad y Reconciliación (Peruvian Truth and Reconciliation Commission; CVR), 1, 19, 28n39, 30n61, 32-33n85; alternatives to official report, 19, 24, 59-64, 168-169, 172, 240241; Audiencias públicas (public hearings by CVR), 4-5, 11, 15, 27n22, 28n37, 29-3on48, 75, 116-117, 168-169, 197, 201-202; commissioners, 4-6, 27n24, 27n28, 27n31, 28n4o, 103, 218 (see also individual names); documentation, 5, 27n27, 137; debate about, 9, 10, 19, 29n43, 29-3on48, 103, 168-169, 218; Final Report (Informe final), 6-11, 1314, 17, 22, 25n3, 27n32, 28n35, 28n37, 29n41, 39, 71n53, 71n62, 72nn66-67, 72n73, 73n77, 101n2, 101n13, 122n43, 138ng, 151n2, 179-181, 188, 194n2, 194n4, 25on3, 253n33; Hatun Willakuy, 11, 25n3, 27n32, 28n36, 28n39, 3on5o; mandates, 4-6, 15-16, 122n 43, 189, 192, 201, 215n21, 220, 257; presentation of Final Report, 103-119, 121n3o, $122 \mathrm{n} 47,123 n 48$; reaction to, $6,10-11$, 20, 128, 183-184, 189-190, 218-219; statistics/figures, 1, 7-9, 25n3, 28n35, 28n39, 29-3on48, 57-58, 6o, 104, 199, 214n7, 215n2O, 256, 272-273n2

Commemorative Acts, 17, 19, 24, 3334n95, 74n95, 113, 115-117, 179-195, 207, 221, 222, 250n5, 264, 268. See also Sacsamarca (town) 
Communist Party of Peru-Shining Path. See Sendero Luminoso

Conga, 13-14. See Mining

Constitutional Crisis of 1992, 4, 29n44.

See also Fujimori, Alberto

Contreras, Carlos, 107, 120nn12-14

Coordinadora Nacional de Derechos Humanos (National Human Rights Coordinator), 5, 28n33

Coronel, José, 53, 71n5o

Correa, Ana, 199, 201-202, 211-213, $214 \mathrm{n} 12,215 \mathrm{n} 21$

Correa, Débora, 199, 211-213

Cossio, Jesús, 76, 139-151, 264, 266, 293

Cueto, Alonso, 127-138, 269. See also hora azul, La

Curse of the Qarqachas, The, I, II, and III, $162,173-174$

CVR. See Comisión de la Verdad y Reconciliación

Decree 1097, 12-13, 30n57

Degregori, Carlos Iván, 6, 27nn27-28, 28n34, 29n42, 3on49, 53, 71n49, $78,101 n 8,118,121-122 n 32,122 n 37$, 122n46, 175n2, 194n8, 271-272n1, $276 \mathrm{n} 2 \mathrm{O}$

de la Cadena, Marisol, 28n34, 72n72, $120 n 11$

del Pino, Ponciano, 19, 25n4, 151n2, 153175, 194n14, 264, 267, 276n2o, 293

Desaparecidos (disappeared), 1, 2, 4, 7, 8, $12,15,23,25 \mathrm{n} 3,28 \mathrm{n} 39,29-3 \mathrm{on} 48,53$, 57-58, 6o, 71-72n64, 75, 87, 101n2, 115, 117, 121-122n32, 128, 163, 184, 193, 201-203, 211, 217, 230, 236, 238, 242-243, 255-256, 262, 269-270, 272-273n2. See also Victims

Dios perdona el pecado, el incesto no,
Jarjacha III (God Forgives Sin, Not Incest, Jarjacha III), 154, 162

Dios tarda pero no olvida (God Is Late but Does Not Forget I-II-III), 153, 158-162, 169,173

Dirty War, 10, 29n44, 255-276

Drawings, $17,19,22,37,39-43,52,54-$ 55, 57-61, 66-67, 68n5, 68n10, 68n12, 69n3o, 71n47, 71n61, 72n67, 72n75, 72-73n76, 75-102, 117, 188, 264, 266. See also Comic strips

Drinot, Paulo, 10, 28n38, 29n42, 29n45, 3on55, 32n71, 107, 120n15, 276n21

El Salvador, 68n5, 256, 262, 272-273n2 Empathy, 19, 22, 23-55, 66, 78, 172, 265-267, 269

Escallón, María Elvira, 3, 26n13

Exhibits, 3, 11, 12, 15, 22, 3on56, 3on61, 31n67, 32n72, 33-34n95, 42-43, 108, 120n5, 202-203, 205

Fajardo Stars, 217, 219, 222-223, 226229, 239-240, 247, 249-250, 250n1

Film. See Cinema

Flam, Gila, 246-247, 253n41

Folk songs. See Song

Forced sterilization, 212, 215n21. See also Fujimori, Alberto

"Fosas Clandestinas" ("Hidden Graves"), 217-220, 222, 247-248, 252n23

Franco, Jean, 26o-263, 274nn9-10, 274-275n12, 275nn14-16

Friedlander, Saul, 25n5, 26nn7-8, 257, $265,274 \mathrm{n} 4$

Fujimori, Alberto, 1, 4-7, 9-11, 25n2, 27n27, 28n40, 29n44, 29n47, 7172n64, 121-122n32, 182, 188, 208, 210, $212,244,247,252 \mathrm{n} 21$ 
García Canclini, Nestor, 109, 120n18, 275n15

García Márquez, Gabriel, 261-262, 274n11

García Pérez, Alan, 4, 7, 9, 11-12, 163, 169, 189-19o

Garza, Cynthia, 3on63, 197-215, 263, 266, 293

Germany, 11, 128, 258, 274n6. See also Holocaust

González, Olga, 25n4, 26n16, 3on53, 31n68, 32n72, 74n94, 120n4, 251n8, 269, 276n 20

González Cueva, Eduardo, 27nn24-26, 27n3o, 27n32, 28n4o, 29n47

González Prada, Manuel, 207-208, $215 \mathrm{n} 17$

Gorriti Ellenbogen, Gustavo, 181, 194n5, 252n19, 271-272n1

Grandin, Greg, 26n19, 271-272n1

Graphic Novel. See Comic strips

Guaman Poma de Ayala, Felipe, 15, 68n1o, 117

Guatemala, 18, 25n3, 30-31n65, 256, 262, 272-273n2, 275n15

Guerin, Francis, 32n75, 69n21, 69n28

Guzmán, Abimael ("President Gonzalo"), 6-7, 9, 25n2, 29n44, 85, 87, 209-210, $215 \mathrm{n} 18$

Hallas, Roger, 32n75, 69n21, 69n28

Hatun Willakuy. See Comisión de la Verdad $y$ Reconciliación

Hayner, Priscilla, 26n19, 273n3

Heilman, Jaymie Patricia, 25n4, 28n34, 276n2o

Highlands, 1, 7, 9, 12, 15-16, 20, 24, 37, $39-41,43,53,58-59,67 \mathrm{n} 2,68 \mathrm{n} 5$, 72nn71-72, 104, 106, 107-108, 121n26,
$131,167,179,188,200,233,264,266-$ $267,269-270$

Hiroshima. See Japan

Historietas. See Comic strips

Hite, Katherine, 30n55, 33n91, 269-27o, 276n21

Holocaust, 26n7, 26n18, 275-276n19; Auschwitz, 17-18, 23; post-Auschwitz problem, 2, 23, 25-26n6, 257-259, 271, 274n6; Yale testimonies, 17

hora azul, La (The Blue Hour), 19-20, 22, 127-138, 269

Hostage crisis. See Japanese Embassy hostage crisis

Huaccahi, Walter, 190

Huamanga. See Ayacucho (city)

Huancavelica (department), 7, 8, 37, 38, $52,73 n 81$

Huancavelica (town), 12, 21, 38, 48, 49, 51, 52-58, 63-65, 67n2, 7on41, 7onn44-45, 71nn47-48, 71n51, 71n54, 71n56, 71nn59-6o, 72n7o, 72-73n76, 73n79, 73nn87-88, 73nn9o-91, 159

Huanta (town), 12, 21, 47, 59, 201

Huánuco (department), 7, 8

Huerta, Alex, 187, 194n12

Humala, Ollanta, 13

Human rights abuses, 4, 9, 13, 27n22, 27n27, 59-6o, 71-72n64, 130-131, $255^{-258}$

Huyssen, Andreas, 25n5, 26n7

Ica (department), 8, 230, 251n12

Inca, 107, 115, 120n7, 187, 270

Incest in the Andes, 162, 173-174

Inter-American Court of Human Rights, 5, 33-34n95

Isbell, Billie Jean, 31nn66-67, 32n73, 32n84, 251nn8-9 
Janampa, Orlando, 183-185, 189, 194$195 \mathrm{n} 16$

Japan, 3, 26n15, 42-43, 190

Japanese Embassy hostage crisis, 9, 24, 25n2, 33-34n95, 74n95, 247

Jelin, Elizabeth, 18, 26n11, 30-31n65, 32n82, 192, 194, 195n17, 232, 236, 252n26, 253n3o, 275nn17-18, 275-276n19

Jiménez, Claudio, 112-116, 122nn34-36

Jiménez Quispe, Edilberto, 19, 22, 31n67, 33n86, 68n4, 71n61, 75-102, 121n3o, 122nn36, 251n8, 264, 266, 293-294

Jiménez family of artisans, 19, 31n67, 109-110, 116, 118-119, 121n23, 122n45

Junín (department), 7, 8

La Cantuta Massacre, 31n67, 71-72n64

LaCapra, Dominick, 26n7, 26n18, 33n89, $69 n 21$

Lane, Jill, 3on62, 214n1o

Laplante, Lisa J., 3on51, $30 n 64$

Larucha (Little Parrot), 226-228

La Serna, Miguel, 25n4, 151n2, 276n20

Latin America, 2, 4-5, 25n5, 71n55, 162, $197,215 \mathrm{n} 21,241,255^{-276}$

Laub, Dori, 17-18, 32n77, 32nn79-8o

Lazzara, Michael J., 26n11, 32n8o

Leiby, Michele, 29-3on48, 72n67

Lemlij, Moíses, 31n68, 251n8

Lerner Febres, Salomón, 7, 9, 14, 28n38, 103, 117, 120n3, 138n3, 169, 203

Lima (capital), 8, 12, 16, 23, 30n55, 32n72, 63, 68n5, 103, 107, 119, 131, 153, 155-157, 163, 167-168, 198, 201, 203, 206, 207, 209, 214n12, 218, 224, 227, 231-24O, 247, 252-253n28, 253, 26927o. See also Cinema; Ojo que Llora, El; Tarata Street bombing
Lima (department), 8, 65, 96-97, 120n21, 230, 208, 248

Limeños, 9, 15, 20, 27, 33n86, 64, 7172n64, 87, 128-129, 137, 157, 171, 186, 200, 203, 266-267

Literature, 1, 3, 17, 19-20, 22, 42, 69n23, 69n29, 76, 104, 127-138, 221, 251n1o, 255, 261-264, 266, 269, 274-275n12. See also hora azul, La; Rupay

Longoni, Ana, 18, 26n11, 30-31n65, 32n82, 275n17

López Antay, Joaquin, 107-111, 120 10

López Liceras, Juan, 190

Lucanamarca (town), 12, 21, 38, 74n95, 179-181

Lugar de la Memoria. See Memory

Luricocha (town), 21, 131

Macera, Paulo, 31n66, 120n8

Maclear, Kyo, 3, 26n14, 69n24, 69nn2729, $70 n 36$

Mallon, Florencia, 32n8o, 63n29, 69n23

Manrique, Nelson, 28n34, 111, 121n31, 276n 22

Mao Tse-tung, 76, 80, 103, 209, 220, 225, $226,227,244,252 n 21$

Maps, 8, 21; "drawing maps," 39-40, $50-52$

Mariátegui, José, 76, 80

Masks, 197-200, 209-210

Massacres, 53, 57, 6o, 65, 7onn43-44, 74n95, 81, 139-151, 200, 210, 217-219, 230, 238, 253n36, 255-256, 261, 266

Mass graves, 24, 65-66, 200, 201. See also "Fosas Clandestinas"

Memory, 29n42, 181-182, 194-195n16, 208-211, 276n22; battles/contested/ negotiations, 2, 9-14, 16, 127-138, 192-194, 255, 270-271; entrepreneurs, 
183-185, 232; human rights, 9-10, 24, 29n42, 275n17; making of, 267-270, 275n18; memory museums, 10, 12, 24; retablos as, 111-113, 117-118; salvation, 9-10, 24, 29nn42-43; sites, 2, 13, 15, 17, 32n81, 220; sounds of, 220, $250 n 6$. See also Colectivo Yuyarisun; Rescate por la Memoria

Menchú, Rigoberta, 18, 32n78, 274n15

Mendoza, Angélica, 201

Military. See Armed forces (state)

Milk of Sorrow, The. See teta asustada, La

Millones, Luis, 31n68, 251n8

Milton, Cynthia, 1-74, 101n4, 101n9, 105, 120n2, 121n26, 122n44, 175n1, 194n1, 251n8, 259-26o, 264, 265, 269, 276n21, 294

Mining, 13-14, 107, 198-199

Minow, Martha, 32n81, 33n9o, 69n25

Montesinos, Vladimiro, 5, 121-122n32, 210

Movimiento por Amnistía y Derechos Fundamentales (MOVADEF), 11

Movimiento Revolucionario Túpac Amaru (Revolutionary Movement of Túpac Amaru; MRTA), 6, 7, 9, 25n2, 28n39, 29n44, 63, 72-73n76, 73n9o, 8o. See also Japanese Embassy hostage crisis MRTA. See Movimiento Revolucionario Túpac Amaru

Museums, 16, 31n67, 33-34n95, 202205, 207, 213; exhibitions, 33-34n95, 68n9; memory, 10, 12, 24. See also Sin Título/Técnica Mixta

Mythical figures, 156, 162, 173-4, 175n2

Narrative, 248-249, 253nn35-36, 259; absence of, 205; alternative, 3-4, 19, 24, 193; art as, 18-20, 23-24, 32n81,
37-74, 77, 188, 215n21, 219-222, 238, 241-243, 247, 265-269; historical, 7, 28n4O, 181-182, 186, 257; human rights, 9-12, 24; national, 9, 14-15, 111-112, 191-194, 244-245, 265-269; retablos as, 103-112, 121n29; salvation, 24, 67n2. See also Cinema; hora azul, La; Sin Título/Técnica Mixta; Testimony National Human Rights Coordinator. See Coordinadora Nacional de Derechos Humanos

Newspapers, 15, 20, 109, 110, 139-140, 164, 202-204, 206

NGo. See Non-Governmental Organizations

Non-Governmental Organizations (NGO), 12, 15, 20, 28n33, 29-3on48, 3on59, 37, 39-43, 51, 6o-61, 68n7, 7on31, 73n82, 76, 101n5, 183, 186, 188, 190, 195, 201, 240, 264-265, 270. See also Colectivo Yuyarisun

Nora, Pierre, 220, 250n5

Novel(s). See Literature

Ojo que Llora, El (The Eye That Cries), 11-14, 23-24, 3on55, 3on59, 269-270, $276 \mathrm{n} 21$

Olivares, Edgar, 190-192, 194n13, 194n15

Oral Tradition. See Testimony, oral Organizations, 68n5; human rights, 5 , 6, 10, 12, 29-3on48, 3on58, 39, 51, 128, 179, 183-184, 215n21, 220, 263, 272-273n2; grassroots, 15, 183-184. See also NGOs; individual names Ortega, Julio, 1-2, 25n1

Ortega Matute, Palito, 19, 20, 22-23, 33n86, 153-175, 264, 267. See also Cinema 
Paintings, 12, 16, 17, 22, 31n66, 48, 5152, 6o, 63, 66, 68n12, 69n3o, 71n47, 72n75, 72-73n76, 73n79, 104, 107-108, 139, 264, 270; contests, 38-43. See also Retablos; Tablas

Pajuelo, Ramón, 43, 69n18, 70n33, 72n75, $101 n 3$

Paniagua, Valentín, 5, 6

Partido Comunista del Perú. See Sendero Luminoso

Performance, 3, 15, 17, 19, 22, 31n70, $117,118,179,186-188,191-192,194-$ 195n16, 197-214, 214nn2-3, 214n12, 215n19. See Yuyachkani

Peruvian Truth and Reconciliation Commission. See Comisión de la Verdady Reconciliación

Photographs, 13, 14, 17, 105, 114, 119, 165, $184,185,187,204,207,213,219$

Photography, 3, 12, 17, 20, 54, 67n2, 71n6o, 110, 140, 203, 204, 213, 266. See also Exhibits; Yuyanapaq

Piérola, Nicolás de, 206

Plaza, Nelly, 68nn8-7, 68n1o, 68n12-16, 7on31

Poetry, 2, 23, 38, 58, 67n2, 73n88, 185, $188,191,207,222,238-247,248,258-$ 259, 274n6, 274n 8

Police forces, 58-59, 230-231, 253n31; artistic depictions of, 73n79, 185-188, 190-192, 243, 245; defeat of Sendero Luminoso, 179-183, 194n7; responsibility, 7, 28n39. See also Armed forces (state); sinchis.

Poole, Deborah, 22, 28n34, 33n87

Portocarrero, Gonzalo, 226, 252n2o, 271-272n1

Prado, Liliana, 68nn8-7, 68n1o, 68n12, 68n14, 68n16, 7on31
Post-conflict era, 2-4, 9, 25n2, 3on63, $41-42,53,61,66,71 n 55,128,222,247$, $249,255-276$

Public hearings (audiencias públicas). See Comisión de la Verdad y Reconciliación

Puno (department), 8, 155, 156, 159, 199, 276n22

Putis, 47-48, 65-66, 74n93, 74n95, 139

Quechua, 6, 7, 16, 27n28, 58-59, 75, 103, 112, 116, 122n 4O, 151n1, 167, 168, 175n2, 186, 191, 198, 200, 212, 214n4, 214n7, 218, 222, 235, 237, 242, 250nn2-3

Quijano, Aníbal, 31n67, 111, 121n28

Quinua, 21, 44, 45, 46, 47

Rabe, Stephen G., 271-272n1, 275n13

Ralli, Teresa, 197, 199, 201, 207, 211

Reátegui Carrillo, Félix, 24-25, 34n97

Reconciliation, 6, 19, 37-39, 41, 61, 63, 117, 129, 134-137, 188-189, 194, 253n38

Re-enactments. See Commemorative acts

Rénique, José Luis, 32-33n85, 33n93, 111, $121 \mathrm{n} 27,276 \mathrm{n} 22$

Reparations, 5, 10, 23, 37, 6o-61, 122n43, 179, 181-183, 189-192, 195n18, 257

Rescate por la Memoria (Recovering/Rescuing Memory) contests, 19, 22-23, 37-74; Ayacucho, 37-38, 58, 62, 67n2, 69n1o, 7on46, 71n48, 71n52, 72n7o, 73n84; Huancavelica, 37-38, 49, 51, 55, 56, 64, 65, 67n2, 7on41, 7onn44-45, 71n48, 71n51, 71n54, 71n56, 71n59, 72n7o, 73n81, 73nn87-88, 73nn9o-91; publication, 181, 188, 194nn6-7, 194nn9-10, 195n17; Sacsamarca, 
68n4, 181, 188, 194nn6-7, 194nn9-10, 195n17. See also Colectivo Yuyarisun

Retablos (3-D wooden triptychs), 12, 15, 16, 19, 4O, 47, 69n29, 75-76, 101nn3-4, 103-123, 251n8, 264; asanteros to retablos, 104-107

Revolutionary Movement of Túpac Amaru. See Movimiento Revolucionario Túpac Amaru (MRTA)

rincón de los inocentes, $\mathrm{El}$ (The Innocents' Corner), 19, 153-154, 162, 165, 167-175

Ritter, Jonathan, 20, 25n4, 31n68, 44, 7on34,101n3, 217-253, 264, 268, 294

Rojas-Pérez, Isaías, 22, 33n87

Rondas/ronderos (self-defense patrols), 10, 28n39, 48, 6o, 77, 81, 83, 95, 97

Rossell, Luis, 76, 139-151, 264, 266, 294

Rowe, William, 16, 32n74, 121n29, 122n33

Rubio Zapata, Miguel, 20, 197, 199, 203, 205, 214, 215nn13-16

Rupay, 20, 22, 76, 139-151, 266. See also Comic strips

Sacsamarca (town), 21, 38, 68n4, 268; May 1983 victory over Sendero Luminoso, 73n79, 179-195. See also Rescate por la Memoria (Recovering/Rescuing memory) contests

Sánchez, Gonzalo, 3, 26n13, 27n32

Sancos (town), 179-181, 183, 188, 191

Sarhua, 15, 21, 32n72, 120n4, 139, 251n8, 269. See also Art, tablas

Scarf of Hope. See Chalina de Esperanza

Schelling, Vivian, 16, 32n74, 121n29, 122n33

Sculpture(s). See Art, 12, 13, 104, 269

Self-defense patrols. See Rondas/ronderos Senderistas. See Sendero Luminoso

Sendero Luminoso (Shining Path), 3on6o, 252n21, 268-27o, 271-272n1, 276n2o; artistic depictions of, 19, 47-51, 53-54, 59-6o, 66, 7onn43-44, 72n75, 73n79, 73n9o, 79-87, 112-113, 153-154, 158159, 162-167, 173, 185-188, 190-192, 200-214, 220-222, 243; causes of, 10, 20, 25n4, 28n34, 29n42, 72n72; cult of violence, 115-116, 271-272n1; defeat, 6, 9, 25n2, 73n79, 74n95, 179-183, 257; forced displacement by (retiradas), 77 , 88, 101n12; memory and, 24, 29n44, 33n93, 269; organization of, 101n13; "People's War," 1, 20, 29n44, 225-226; and pumpin, 225-231, 236, 244, 248, 252n19; reprisal by, 44, 243; resistance to, 268-269, 276n2o; responsibility, 4, 7, 9, 28n39, 57, 6o-61, 130-131, 199-200, 218, 238, 256, 262; senderos/ senderistas, 266; senderologists, 165; suspected of being, 57, 89, 98-99, 228-229, 253n31; women and, 58, 72n68, 188, 193-194; and youths, 57, 71n62, 87, 224

SER. See Asociación de Servicios Educativos Rurales

Shining Path. See Sendero Luminoso Sinchis. See Armed forces (state)

Sin Título/Técnica Mixta, 19-20, 22, 197-215

Sikkink, Kathryn, 271-272n1, 273n3

Siluetazos (silhouettes), 2, 26n11

Sin, 162

Song, contests (Concursos), 19, 38, 67n2, 217-253; huayno (wayno), 15, 212, 224, 239, 241, 252n17, 253n34; protest, 221-222; pumpin, 15, 19, 217, 219-253, 264, 268; song book (cancionero), 233, 235-236, 239; testimonial, 219-222, 231-250 
Soto Vasquez, Edmundo, 48, 49

South Africa, 5, 30-31n65, 249

Southern cone, 4, 29n44, 255, 257

Spanish Conquest, 1, 15, 113, 115, 187; independence from, 110, 265; language, $6,103,127,186,200,237$

Stern, Steve J., 2, 25nn4-5, 26n9, 26n18, 28n34, 29n42, 29n44, 73n82, 74ng2, 195n19, 255-276, 294

Symbolism, 43-44, 47-48, 50-52, 54, $58-59,61,63,65,70 n 43,106,113,115$, 117, 138ng, 155-156, 175n2, 183-184, 189, 200, 207, 209-211, 218, 241, 244, 269-270

Tacna (department), 8, 207-208

"Tacna” (song), 206

Tarata Street bombing, 9, 31n67, 203

Taylor, Diana, 26n18, 30n63, 214n1, $214 \mathrm{n} 8$

Testimony, 12, 33n93, 103, 118, 133, 153, 168, 197, 200-202, 205, 214, 215n21, 217-253, 263-264, 266-268, 274n5, 275n15, 275-276n19; art as, 15, 20, 22, 31n68, 37-74, 214, 231-249, 264, 266; Audiencias Públicas (Public Hearings by CVR), 4-5, 11, 15, 27n22, 28n37, 29-3on48, 75, 116-117, 168-169, 197, 201-202; literature, 69n29; oral, 4, 1718, 32n75, 121n29; testimonio, 20-21, 32n8o, 42, 66, 69n26, 154, 238-242, 247, 253n35, 263; validity of, 32n8o, 163, 275n15. See also Cinema; Rescate por la memoria; Song; Yuyachkani

Theidon, Kimberly, 25n4, 29n42, 3on64, 7on37, 7on43, 72n67, 73n82, 116, 122n39, 138ng, 194n14, 253nn37-38, $276 \mathrm{n} 20$

Toledo, Alberto, 6, 27n31
Truth Commissions, 4-6, 23, 26n16, 26nn19-20, 69n25, 249, 256-257, 265-266, 272-273n2, 273n3, 275276n19. See also Comisión de la Verdady Reconciliación (CVR)

Truth and Reconciliation Commission, Peru. See Comisión de la Verdad y Reconciliación (CVR)

Turino, Thomas, 251n15, 252n27

Ubilluz, Juan Carlos, 31n68, 135, 138n21

Uchuraccay, portrayal of events surrounding journalists' deaths, 21, 139-15o, 151n2, 266, 276n2o

Ulfe, María Eugenia, 13, 3on56, 3on62, 31n68, 69n29, 74n95, 101nn3-4, 103$123,264,265,276 \mathrm{n} 2 \mathrm{O}, 294-295$

Universidad Nacional de San Cristóbal de Huamanga, Ayacucho, 71n62, 75, 115, 190, 223, 239

Urrutia, Jaime, 120n13, 121n25

Valz-Gen, Viviana, 54, 71n58

Vargas, Julián, 199, 204, 209

Vargas Llosa, Mario, 127; Commission, 145-147, 151n2

Vásquez, Chalena, 251n9, 252n16, 253n32

Vergara, Albilio, 7on36, 101n7, 251n9, 252nn16-17, 253n32

Vich, Víctor, 19-20, 31n68, 31n70, 127138, 263, 269, 295

Victims, dead, 12, 31n67, 48, 50, 54, 5758, 61, 73n82, 73n9o, 77, 89, 91, 115117, 130-131, 134, 194n3, 203, 217, 230, 240, 242, 262; definition, 33n94, 61, 270; disappeared, 2, 4, 7, 12, 15, 53, 5758, 71-72n64, 163, 184, 193, 201-203, 211, 217, 230, 238, 242-243, 255-256, 
262, 269-270; map, 8; orphans, 54, 93, 241; refugees, 47, 132, 231-233, 239, 252n25, 252-253n28; registry, 122n43; statistics, 1, 7, 8, 25n3, 28n33, 28n35, 28n39, 29-3on48, 6o, 75, 121-122n32, 256, 272-273n2; tributes to, 117-118, 183-194, 201, 269; victimhood, 195n18, 237, 248; voice of, 218, 250n3; widows, 54, 73n82, 189, 194, 206

Víctor Fajardo (province), 21, 22, 44, 75, 101n3, 217-253

Videos, 154, 162, 209, 219; incriminating, 5, 121-122n32. See also Cinema

Villar, Alfredo, 76, 139-151, 264, 266, 295

VRAE. See Apurímac-Ene River Valley, 13, $30 n 60$

War of the Pacific, 20, 107, 202-208, 211
Waswantu Plateau, 217-219, 223-225, 228-231, 234, 237, 245-247, 252n16

Wilson, Richard, 249, 253n42

Witnessing, 3, 17-20, 25n4, 31n68, 32n75, 32n8o, 32n83, 33n86, 42-44, $48,50-51,53,63,66,69 n 21,73 n 82$, 75-76, 113, 162, 197-198, 200, 230, $239,244-245,263-265,268-269,271$, 274n 5

Woolf, Virginia, 17

Yale Holocaust testimonies. See Holocaust

Yezer, Caroline, 25n4, 27n29, 251n8

Young, James, 26n7, 32n81

Yuyanapaq (photo exhibit), 15, 22, 30n61 Yuyachkani, 15, 19, 20, 22, 3on63, 104, 197-215, 266

Zárate, Wari, 13 